Vitor Borges da Silva

\title{
DISTRIBUIÇÃO MODAL RODO-FERROVIÁRIA EM UMA REDE DE EXPORTAÇÃO DE AÇÚCAR A GRANEL PARA O PORTO DE SANTOS
}

Dissertação apresentada à Escola de Engenharia de São Carlos da Universidade de São Paulo, como parte dos requisitos para obtenção do título de Mestre em Engenharia Civil - Área de Transportes.

Orientador: Prof. Titular João Alexandre Widmer

São Carlos, 2005. 
Dedico este trabalho aos meus pais, Zacarias e Balbina, pelo amor e apoio de sempre, aos meus irmãos, Monique e Fred, pela amizade e companheirismo, e também a minha primeira sobrinha Yasmin, pelo brilho que trouxe à nossa família. 


\section{AGRADECIMENTOS}

Ao Professor João Alexandre Widmer, pela amizade, conselhos de vida e comprometimento na orientação dessa dissertação.

À CAPES pela bolsa de estudos concedida para a realização do mestrado.

Aos meus amados pais, pela filosofia de vida e pelo apoio que nunca faltou.

Aos meus queridos irmãos, que são meus eternos amigos, companheiros e conselheiros.

Aos Engenheiros César Frossard e Vandualdo Bigoto, pela disposição para ajudar e pelas informações imprescindíveis para a investigação dessa pesquisa.

Aos “irmãos” e companheiros Karênina, Mané, Gilmerson, Waldomiro, Celane e Ricardo, pelas muitas horas de parceria em nosso grupo de pesquisa.

Á Márcia, pelo carinho, companheirismo e compreensão.

Aos Engenheiros Rafael José Rorato e Neuto Gonçalves dos Reis, pelos esclarecimentos em pontos vitais desta pesquisa.

Aos amigos de todo sempre, de longe ou perto, que mesmo nos momentos difíceis apoiaram e torceram por mim.

Aos novos amigos, João, Antônio, Deise, Giovano, Cira e Simone.

Aos funcionários do STT, Heloísa, Beth, Magali, Sueli e Fábio. 


\section{SUMÁRIO}

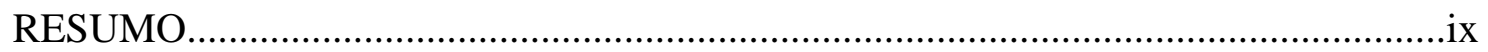

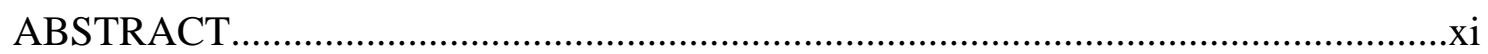

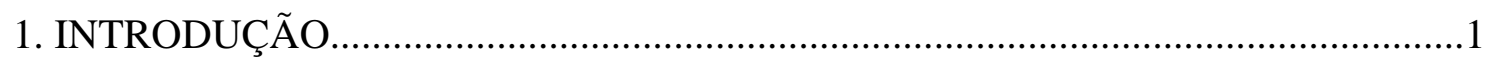

1.1. Setor Sucroalcooleiro: história, atualidade e perspectivas........................................1

1.2. Transportes no Mercado de Açúcar..........................................................................

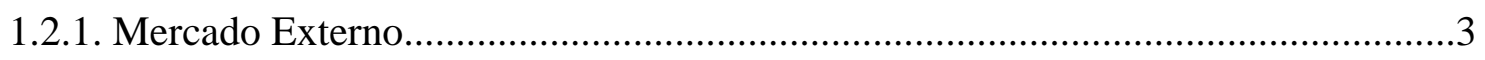

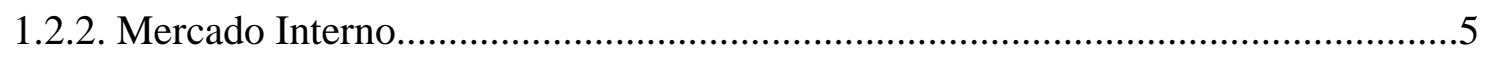

1.3. Divisão da Matriz Modal Brasileira..................................................................

1.4. Cenários no Transporte de Açúcar......................................................................8

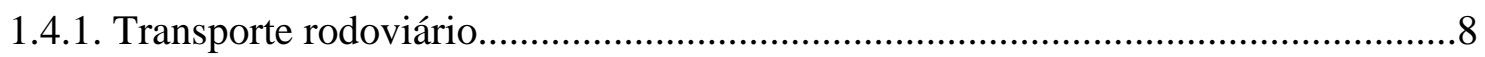

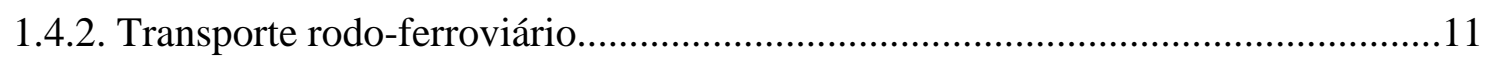

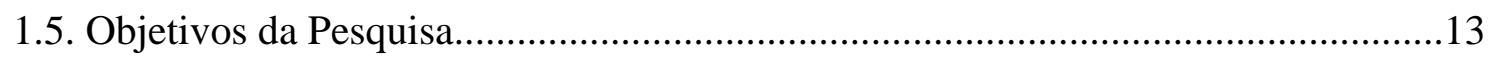

1.6. Organização da Dissertação................................................................................ 14

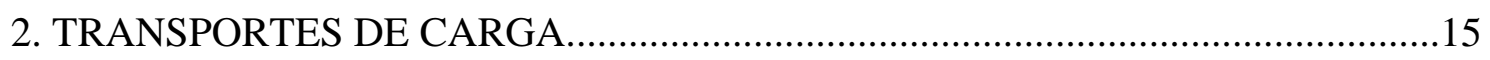

2.1. Demanda por Transportes de Carga.................................................................15

2.2. Aspectos Sobre o Transporte Rodoviário de Cargas Utilizando CVCs....................18

2.3. Estratégias Aplicadas ao Modo Ferroviário para Obter Maior Inserção no Mercado

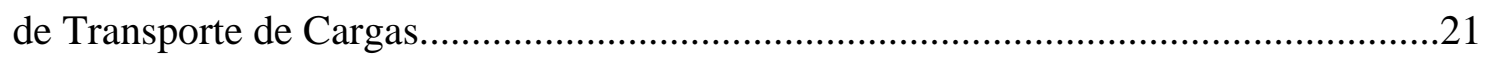

2.4. Estrutura de Formação dos Custos dos Fretes no Transporte Rodoviário e Ferroviário de Cargas...........................................................................................25

3. FLUXO EM REDE E APLICAÇÃO EM SIGs......................................................29

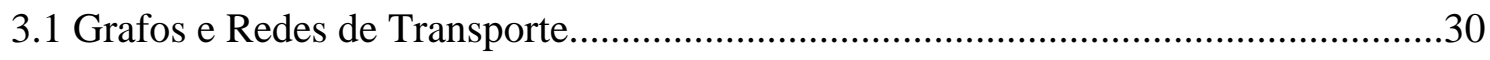

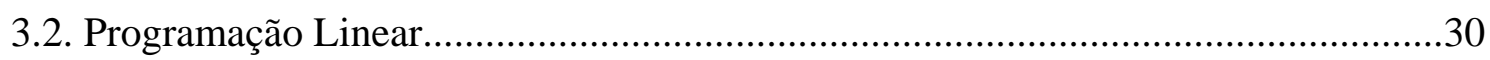

3.2.1. O Problema do Transporte e do Caminho Mínimo..............................................31 


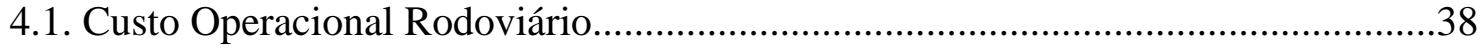

4.1.1. Custos Diretos das Operações dos Veículos..............................................................

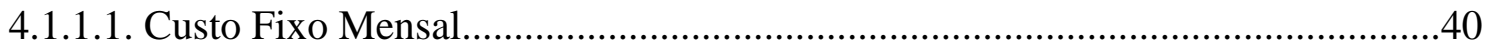

4.1.1.2. Custo Variável por Quilômetro....................................................................41

4.1.2. Despesas Indiretas Administrativas da Operação................................................41

4.1.3. Cálculo Final dos Custos Rodoviários Percebidos...............................................43

4.2. Frete do Transporte Rodoviário.....................................................................44

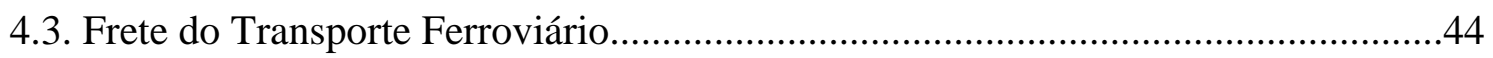

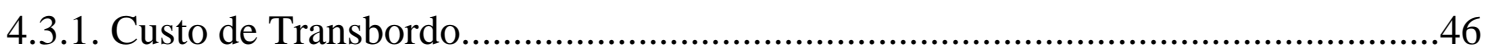

4.3.2. Composição do Custo Total Rodo-Ferroviário....................................................48

4.4. Modelo de Rede de Transportes........................................................................48

4.4.1. Procedimento de Elaboração da Rede de Transportes Rodoviário.........................49

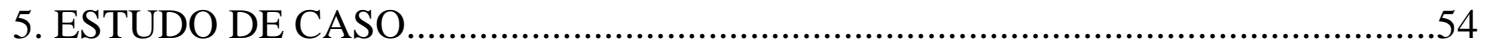

5.1. Apresentação dos Cenários..................................................................................55

5.2. Preparação do banco de dados do TransCAD..........................................................58

5.3. Preparação do Arquivo de Penalidades (pedágios)................................................59

5.4. Execução da Rotina do Problema dos Transportes para o Modelo

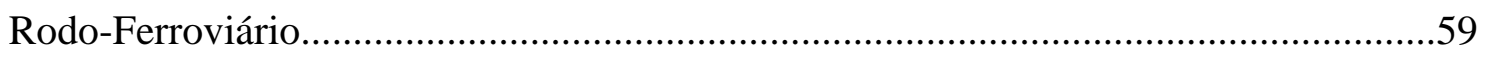

5.5. Execução da Rotina de Caminhos Mínimos para Frota Própria...............................62

5.6. Simulações com Frota Terceirizada.................................................................63

5.7. Cálculo Final dos Custos Absolutos de Transporte no Estudo de Caso....................64

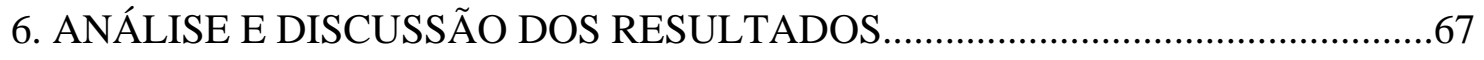

6.1. Transporte Rodoviário Porta-a-Porta: Análise dos Cenários 1 e 2..........................67

6.2. Transporte Rodo-Ferroviário com Restrição de Capacidade: Análise dos

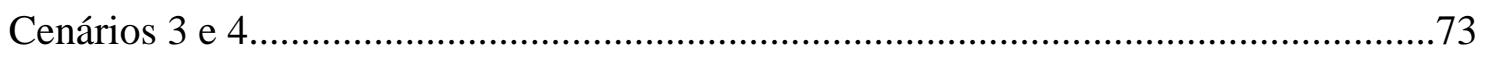


6.3. Transporte Rodo-Ferroviário sem Restrição de Capacidade: Análise dos

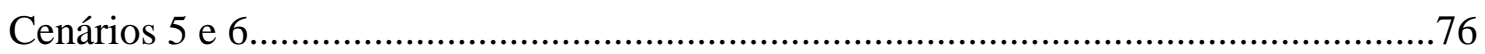

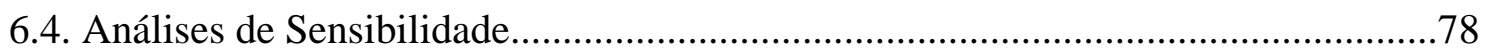

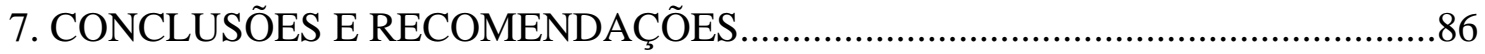

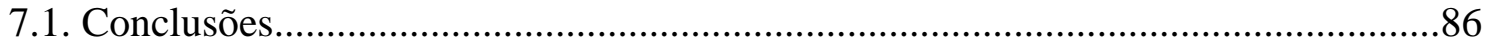

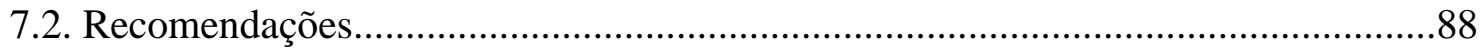

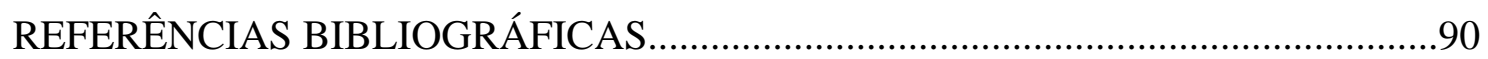

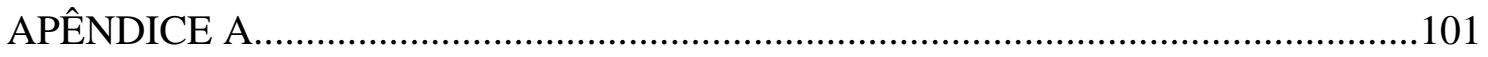

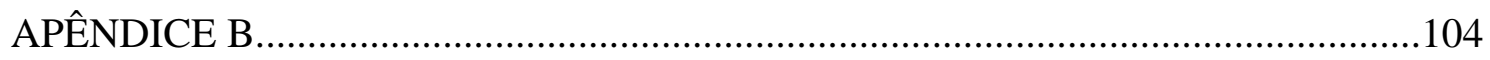

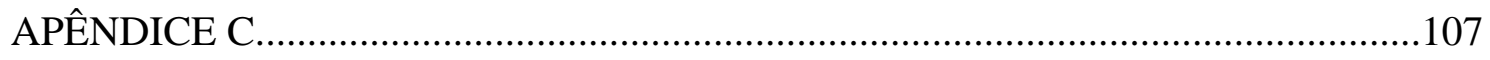

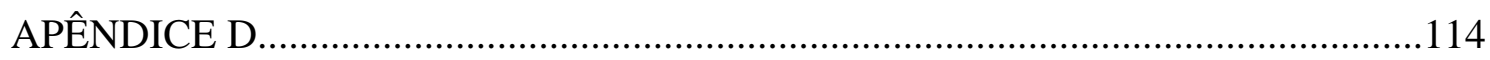

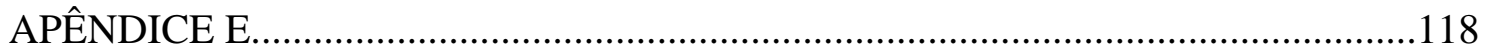

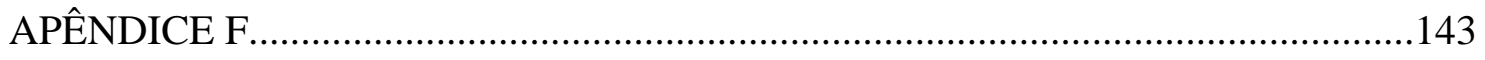

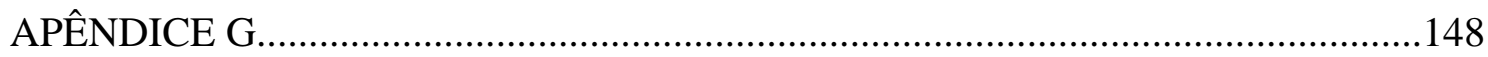

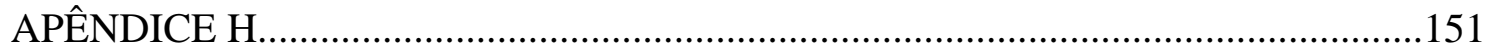

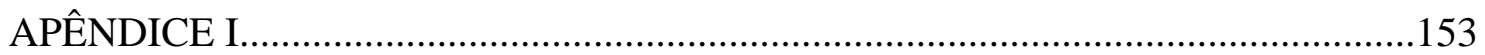

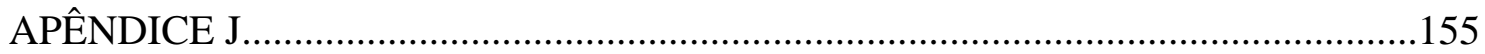

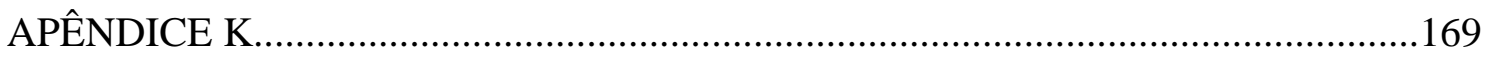




\section{LISTA DE FIGURAS}

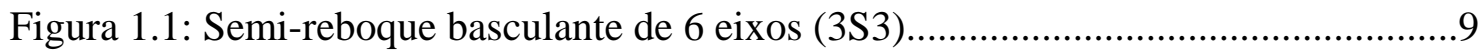

Figura 1.2: Semi-reboque convencional de 5 eixos (2S3)...........................................10

Figura 1.3: Bitrem de 7 eixos (3S2B2) tipo Hopper...................................................10

Figura 1.4: Implemento bitrem graneleiro convencional acoplável a um cavalo

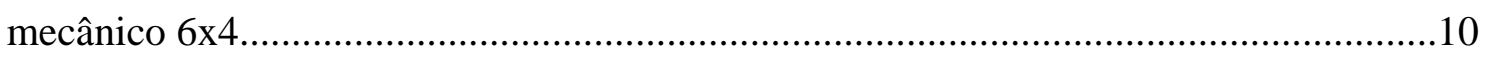

Figura 1.5: Semi-reboque graneleiro no tombador..................................................11

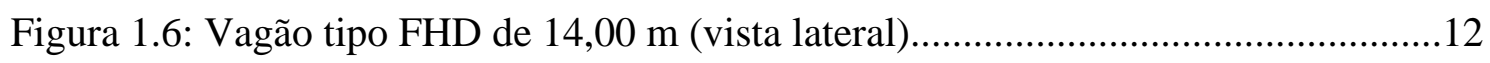

Figura 1.7: Vagão tipo FHD de 14,00 m (vista de cima) ............................................12

Figura 3.1: Exemplo de grafo (NOVAES, 1978)..................................................29

Figura 3.2: Exemplo de uma rede de transporte (NOVAES, 1978) ...............................30

Figura 4.1: Mapa rodoviário do Estado de São Paulo...................................................52

Figura 4.2: Banco de dados do arquivo de linhas referente às rodovias..........................52

Figura 4.3: Mapa de acessibilidade da rede rodoviária do Estado de São Paulo..............53

Figura 5.1: Matriz dos múltiplos caminhos de menores custos entre usinas e terminais intermodais

Figura 5.2: Banco de dados referente às usinas contendo a demanda por transporte de açúcar do mês de dezembro.

Figura 5.3: Banco de dados referente aos terminais intermodais contendo as capacidades de embarque de açúcar no mês de dezembro.

Figura 5.4: Matriz de alocação dos fluxos de transporte de açúcar entre usinas e teminais intermodais.

Figura 5.5: Mapa de caminhos mínimos no ciclo usina-terminalusina

Figura 5.6: Custos mínimos absolutos relativos a um ciclo usina-terminal-usina utilizando uma CVC tipo 3S3B3. 63

Figura 6.1: Vantagem competitiva do 3S2B2 sobre o 2S3 e o 3S3. .68 
Figura 6.2: Vantagem competitiva do 3S3B3 sobre as alternativas rodoviárias. 68

Figura 6.3: Custos absolutos de transporte nas alternativas dos Cenários 1 e 2 . .69

Figura 6.4: Produção mensal de açúcar ao longo da safra 2004/2005 para o conglomerado de usinas. .70

Figura 6.5: Vantagem econômica da operação com frota terceirizada sobre a operação com frota própria.

Figura 6.6: Vantagem econômica relativa mensal da operação com frota terceirizada.

Figura 6.7: Frete mensal médio e intervalo de confiança de fretes observados entre usinas mês a mês.

Figura 6.8: Custos absolutos mensais no transporte rodoviário e rodo-ferroviário com restrição de capacidade de embarque de açúcar.

Figura 6.9: Vantagem econômica da operação rodo-ferroviária utilizando frotas terceirizadas nas pontas e nos complementos rodoviários

Figura 6.10: Exemplo comparativo de custos e fretes por tonelada referente às pontas rodoviárias. .76

Figura 6.11: Custos absolutos mensais no transporte rodo-ferroviário com e sem restrição de capacidade de embarque de açúcar. .78

Figura 6.12: Vantagem econômica da operação rodo-ferroviária utilizando frota própria nas pontas rodoviárias.

Figura 6.13: Sensibilidade dos custos de operação da frota própria à incidência do frete de retorno.

Figura 6.14: Sensibilidade dos custos de operação da frota própria ao aumento da quilometragem percorrida mensalmente.

Figura 6.15: Sensibilidade dos custos de operação da frota própria à subtração de parcelas do custo fixo.

Figura 6.16: Sensibilidade dos custos de operação da frota própria 3S3B3 à incidência do frete de retorno.

Figura 6.17: Sensibilidade dos custos de operação da frota própria 3S3B3 ao aumento da quilometragem percorrida mensalmente. 


\section{LISTA DE TABELAS}

Tabela 1.1: Tipos de açúcar e padrões de embalagem para exportação............................4

Tabela 1.2: Tipo de açúcar e padrão de embalagem para o mercado interno.....................6

Tabela 4.3: Tarifas de frete cobradas no transporte ferroviário de açúcar a granel.........47

Tabela 5.1: Descrição do cenário 1........................................................................56

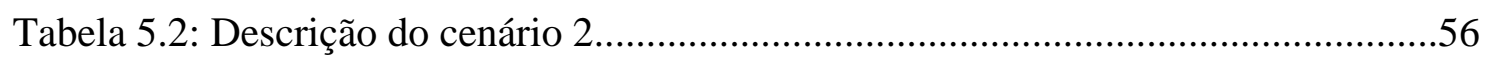

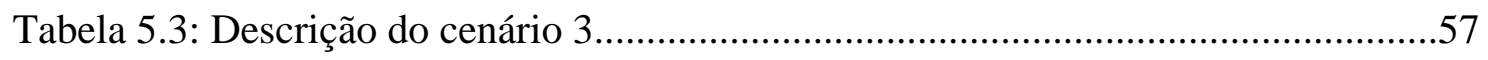

Tabela 5.4: Descrição do cenário 4..........................................................................58

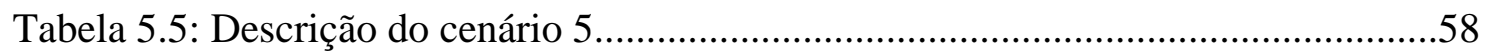

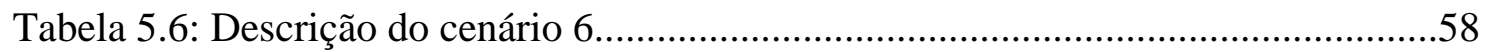




\section{RESUMO}

SILVA, V.B. (2005). Distribuição Modal Rodo-Ferroviária em uma Rede de Exportação de Açúcar a Granel para o Porto de Santos. São Carlos, 2005. 178 p. Dissertação (Mestrado) - Escola de Engenharia de São Carlos, Universidade de São Paulo.

Atualmente, o Brasil é o maior produtor de açúcar do mundo, com uma produção anual de 16,7 milhões de toneladas, onde a metade deste montante destina-se ao mercado externo. Nesse contexto, este trabalho tem o objetivo principal de investigar as principais alternativas de transporte existentes para o açúcar a granel de exportação, e propor estratégias que orientem os agentes envolvidos neste mercado a racionalizar seus custos de distribuição. São criados três grupos de cenários que representam as principais alternativas de transporte neste setor: o rodoviário porta-a-porta; o rodo-ferroviário com restrição de capacidade de embarque de açúcar; e um cenário de longo prazo de transporte rodo-ferroviário sem restrição de capacidade de embarque de açúcar. Em cada um desses grupos existe a opção de se transportar nos trechos rodoviários, tanto no porta-a-porta como nas pontas de acesso à ferrovia, com frota própria ou terceirizada. As tecnologias para frotas próprias investigadas nesse trabalho são as CVCs 2S3 e 3S3, geralmente utilizadas para o transporte do açúcar a granel, e as 3S2B2 e 3S3B3, as quais tem participações incipientes nesse mercado de transportes. A modelagem do problema leva em consideração os custos econômicos para a operação das frotas próprias e os valores de fretes cobrados para o setor tanto no modo rodoviário, como no ferroviário. Esses modelos agregados são simulados com auxílio de um Sistema de Informação Geográfica e de planilhas eletrônicas. Ao final, conclui-se que no transporte rodoviário porta-a-porta, embora existam vantagens econômicas na operação das novas CVCs, nenhuma alternativa de frota própria mostra-se mais viável que a contratação de frota terceirizada no mercado. As análises no modo rodo-ferroviário mostram que este é mais atraente do que o rodoviário porta-a-porta para o mercado de exportação de açúcar, mesmo quando a operação tem restrições de capacidade. Numa operação hipotética sem restrições de capacidade, os ganhos econômicos gerados são da ordem 5,3\% sobre a alternativa rodo-ferroviária com restrição da ferrovia para embarque de açúcar. Sugere- 
se a realização de uma investigação dos custos de investimento na infra-estrutura e material rodante necessários para eliminar as restrições de capacidade para este mercado.

Palavras-chave: Transporte rodoviário; transporte intermodal rodo-ferroviário; CVC; combinações de veiculo de carga; SIG; economia de transportes. 


\section{ABSTRACT}

SILVA, V.B. (2005). Railroad Distribution at a Bulk Sugar Exportation Network to the Port of Santos. São Carlos, 2005. 178 p. Dissertação (Mestrado) - Escola de Engenharia de São Carlos, Universidade de São Paulo.

Brazil is today the largerst sugar producer of the world, with an annual production of 16,7 million tons, where half of this amount is directed to the export market. In this context, the study has the main objective to investigate the transport alternatives for bulk sugar export and to propose strategies to the market agents involved in rationalizing the distribution costs. Three groups of scenerios are created to represent the main transportation alternatives in this sector: the door-to-door road transport; the constrained capacity road-railroad intermodal transport; and a long- term unconstrained capacity road-railroad intermodal scenario. For each of these scenarios the option of the road transport, either in the door-to-door operation or in the accesses to the railroad, with proprietary or third party fleets is investigated. The technologies for proprietary fleets considered in this investigation are the 2S3 and 3S3 combinations, generally used at present for the bulk sugar transportation, as well as the 3S2B2 and 3S3B3 LCVs, which have an incipient participation in this transportation market. The modeling considers the economic costs for the proprietary fleet operations and current freight values charged for road and rail in the bulk sugar transport sector in the region selected for the case study for the third party operation. The aggregate cost models are simulated with the support of a Geographic Information System and electronic spreadsheets. It is concluded that in the door-to-door road transport, even considering the economic advantages of the new LCVs technologies, none of the proprietary fleet alternatives are more cost effective than contracting third party fleets in the market. The railroad alternatives show that this alternative is more attractive than the door-to-door road transport, even considering the constraints in operating capacity. An hypothetical operation with unconstrained capacity is presented, showing that the economic gains of this alternative are in the order of $5,3 \%$ better than the best constrained capacity alternative. A suggestion to conduct an investigation on the investment costs necessary 
to eliminate infrastructure and rolling stock capacity constrains on the railroad network is presented.

Keywords: road transportation; railroad intermodal transportation; LCV; long combination vehicles; GIS; transportation economy. 


\section{INTRODUÇÃO}

O primeiro capítulo deste trabalho apresenta ao leitor o assunto selecionado, informando de maneira ampla em que cenário esta pesquisa está inserida, além dos objetivos e da organização dessa dissertação.

\subsection{Setor Sucroalcooleiro: história, atualidade e perspectivas}

O complexo agroindustrial canavieiro constitui-se na mais antiga atividade econômica do Brasil e suas principais atividades (plantio, colheita, esmagamento e produção de cana-de-açúcar, álcool e açúcar) contribuíram e continuam a contribuir com o crescimento econômico brasileiro. Mesmo que nas últimas décadas tenha ocorrido um avanço considerável nas indústrias de bens de consumo duráveis nacionais, chegando a competir no mercado externo com países desenvolvidos, o setor agroindustrial ainda vislumbra como um dos principais da economia do país (BANCO CENTRAL, 2004). Este fato pode ser explicado devido a diversos fatores como: a cultura adquirida durante a colonização, as condições climáticas e naturais favoráveis, a enorme quantidade de áreas cultiváveis inexploradas e a dependência de tecnologia estrangeira para o desenvolvimento da indústria de ponta.

Em pesquisas recentes divulgadas pelo Instituto Brasileiro de Geografia e Estatística (IBGE) e pelo Instituto de Economia Agrícola do Estado de São Paulo (IEA) pode-se perceber quantitativamente a importância da agroindústria no cenário nacional e paulista. Em 2003, a agroindústria brasileira registrou crescimento de 1,6\% em sua produção, taxa acima da média da indústria nacional (0,3\%), fato que tem se repetido nos últimos três anos. No entanto, o grupo dos produtos industriais derivados da agricultura apresentou recuo de 1,7\%, à exceção dos derivados de cana-de-açúcar $(8,8 \%)$, milho $(7,9 \%)$ e trigo $(0,2 \%)$. Já produtos como soja $(-1,7 \%)$, café $(-11,5 \%)$, algodão (-5,7\%) e laranja (-25,4\%) apresentaram retrações em suas produções. A boa performance da agroindústria pode ser creditada basicamente ao crescimento de produtos industriais utilizados pela agricultura $(17,2 \%)$, como o segmento de máquinas e equipamentos agrícolas (IBGE, 2004). 
No contexto das exportações do agronegócio, o Brasil saltou de US\$23,9 bilhões em 1997 para 31,1 bilhões em 2003, de um total de US\$ 73,1 bilhões incluindo todos os outros setores de exportação, ou seja, em 2003, as exportações do agronegócio representaram 42,5\% de toda a exportação brasileira (IEA, 2004). Nesse mesmo ano, Vicente et al. (2004) destaca que os cinco principais grupos de mercadorias exportadas pelo mercado brasileiro foram: cereais/leguminosas/oleaginosas (US\$ 8,76 bilhões); produtos florestais (US\$ 5,70 bilhões); bovinos (US\$ 4,14 bilhões); suínos e aves (US\$ 2,53 bilhões); e cana e sacarídeos (US\$ 2,33 bilhões). Somados, esses produtos responderam por 75,4\% de todo o valor exportado pelo setor em 2003.

Em situação de destaque encontra-se o Estado de São Paulo, que em 2003 foi responsável por US\$ 7,2 bilhões em exportações no agronegócio, de um total de US\$ 23,1 bilhões em todos os setores, o que corresponde a 31,2\% da exportação total do estado e a 23,1\% das exportações agroindustriais brasileiras (IEA, 2004). Seus principais grupos de mercadorias exportadas foram (VICENTE et al., 2004): bovinos (US\$ 1,61 bilhão); cana e sacarídeos (US\$ 1,52 bilhão); frutas (US\$ 1,29 bilhão); produtos florestais (US\$ 1,10 bilhão); e cereais/leguminosas/oleaginosas (US\$ 470 milhões). No total, esses produtos representam $83,4 \%$ do valor exportado pela agroindústria paulista.

O desempenho demonstrado pelas exportações dos derivados de cana-de-açúcar confere ao Brasil a posição de maior exportador de açúcar do mundo, com uma produção de 320,7 milhões de toneladas de cana-de-açúcar e 22,6 milhões de toneladas de açúcar na safra 2002/2003. Deste montante, metade da produção de açúcar é destinada ao mercado externo e a outra metade divide-se no mercado interno entre indústrias alimentícias e comércios atacadistas. No mesmo ritmo segue o Estado de São Paulo, responsável por aproximadamente $60 \%$ da produção nacional de cana-de-açúcar (192,5 milhões de toneladas) e 63,7\% (14,4 milhões de toneladas) da produção de açúcar na safra 2002/2003 (UNICA, 2004).

Desta forma, os conglomerados de empresas e mesmo as pequenas usinas responsáveis pelo atual status do Brasil no ranking mundial de produção de açúcar, são obrigadas a se manter em constante modernização. Para isso, buscam soluções tecnológicas que aumentem a produtividade nas lavouras, nas indústrias, racionalizem os custos de distribuição, diminuam os custos de produção como um todo, diversifiquem o produto e pesquisem novos tipos de embalagem. 
Tudo isso parece trivial quando se trata do setor industrial, já que as técnicas da engenharia e administração aplicadas à indústria encontram-se plenamente difundidas pelo mundo. Porém no caso do complexo sucroalcooleiro, esses conceitos só começaram a se difundir após o fim do controle estatal. Isso porque, durante o período em que o Instituto do Açúcar e do Álcool (IAA) esteve à frente do setor, foram estabelecidos as chamadas "cotas de produção" e o controle dos preços, ou seja, quem quisesse adentrar o complexo tinha que obter uma cota abandonada ou inativa, já que, de maneira geral, era proibida a formação espontânea de unidades produtoras. Assim, ter acesso a uma cota outorgada pelo Estado passou a ser imprescindível para viabilizar os investimentos no complexo. Já o controle de preços do açúcar e do álcool foi estabelecido em função da concorrência entre São Paulo e Nordeste e das relações atribuladas entre usineiros e fornecedores de cana (BELIK et al., 1998).

Portanto, até meados dos anos oitenta as empresas do complexo não investiam na diferenciação de seus produtos e apenas algumas empresas buscavam uma melhor condição técnica de seus equipamentos. Porém, com a extinção do IAA em 1993, e conseqüentemente com a mudança da política e do ambiente institucional, os investimentos em tecnologia, diferenciação e diversificação do produto têm gerado uma profunda reformulação da agroindústria canavieira no Centro-Sul. Desde então as empresas estão adotando estratégias diferenciadas das anteriores, buscando uma maior competitividade nacional e internacional (BELIK et al., 1998).

\subsection{Transportes no Mercado de Açúcar}

\subsubsection{Mercado Externo}

No que diz respeito ao mercado de frete para açúcar, Caixeta-Filho e Gameiro (2001) afirmam que tanto para a exportação quanto para o mercado interno, as características operacionais e a natureza dos equipamentos são muito similares, porém apresentam estruturas distintas em virtude da demanda envolvida.

O Brasil exporta diferentes tipos de açúcares diferenciados basicamente pela sua coloração e granulometria, sendo que, há pelo menos cinco anos, a Rússia se mantém como a maior importadora do produto brasileiro (UNICA, 2004). Os tipos de açúcares para exportação e seus padrões de embalagem são mostrados na Tabela 1.1. 
Tabela 1.1: Tipos de açúcar e padrões de embalagem para exportação

\begin{tabular}{ll}
\hline \multicolumn{1}{c}{ TIPO DE AÇÚCAR } & \multicolumn{1}{c}{ PADRÃO DE EMBALAGEM } \\
\hline VHP & a granel \\
\hline VVHP & a granel \\
\hline Cristal Especial Extra & saco $50 \mathrm{~kg}$; big bag até $1200 \mathrm{~kg}$ \\
\hline Cristal Especial & saco $50 \mathrm{~kg}$; big bag até $1200 \mathrm{~kg}$ \\
\hline Cristal G.C. (granulometria controlada) & saco $50 \mathrm{~kg}$; big bag até $1200 \mathrm{~kg}$ \\
\hline Demerara (somente no Nordeste) & a granel \\
\hline Refinado Granulado & saco $50 \mathrm{~kg}$ \\
\hline Orgânico & saco $25 \mathrm{~kg}$ \\
\hline
\end{tabular}

Fontes: Cosan, Copersucar, Crystalsev e Sindaçúcar (2004).

Sobre as características e finalidades dos açúcares citados na Tabela 1.1 pode-se dizer:

- O açúcar VHP (Very High Polarization) e o VVHP (Very Very High Polarization) são açúcares brutos para serem reprocessados no exterior, cujos tratamentos do caldo são mínimos ou nenhum, e cujas massas cozidas sofreram lavagem reduzida na centrífuga. Os tipos VHP e VVHP são atualmente os padrões de açúcar bruto das usinas do Estado de São Paulo destinado à exportação;

- O açúcar cristal é de uso geral e pode ser reprocessado para produção de açúcar refinado ou utilizado nas indústrias alimentícias e pelo consumidor final. O cristal é fabricado diretamente da cana-de-açúcar, tem forma cristalizada e passa por tratamentos físico-químicos para sua clarificação, sendo que o nível de clarificação define sua denominação: extra especial ou especial. O açúcar cristal de granulometria controlada (G.C.), além das características mencionadas, possui grãos de tamanho uniforme; 
- O açúcar demerara é utilizado geralmente em processos alimentícios que exigem sabores, cores e texturas especiais. Apresenta cristais regulares e é obtido a partir do caldo da cana-de-açúcar em processo parecido ao do VHP, pois também tem mínimo tratamento de clarificação e lavagem. Atualmente, somente os estados do nordeste brasileiro exportam açúcar demerara;

- O açúcar refinado granulado é indicado para processos com elevado grau de pureza. É obtido pelo refino de açúcar cristal dissolvido, onde se aplica um processo de cristalização controlada;

- O açúcar orgânico é obtido sob rígidos padrões de qualidade e apresenta cristais regulares de coloração levemente amarelada. É utilizado para consumo direto e em alimentos orgânicos industrializados.

O mercado de transporte de açúcar destinado à exportação caracteriza-se pela relação entre os demandantes (usinas e tradings) e os ofertantes (transportadoras e fretistas). Segundo Soares et al. (1997), do ponto de vista logístico o transporte nesse mercado é mais elaborado do que no mercado interno, uma vez que os portos requerem atenções extras, como por exemplo, preocupações com as condições climáticas e ao tipo de prioridade de atracação do navio. Isso determina se o caminhão descarrega direto no navio ou em armazéns eventualmente disponíveis.

Outra característica importante com relação ao transporte de exportação ressaltada por Soares et al. (1997) diz respeito à responsabilidade no transporte. Nesse mercado o produto é vendido FOB (free on board) navio, ou seja, o embarcador, no caso as usinas ou as tradings, é responsável pelo produto e arca com os custos de transporte até a sua colocação no navio.

\subsubsection{Mercado Interno}

O transporte no mercado interno destina-se basicamente a dois grandes blocos: as indústrias alimentícias; e os mercados atacadistas e grandes redes de supermercado, responsáveis pelo abastecimento de mercados de médio e pequeno porte, ou mesmo o consumidor final. Os tipos de açúcares comercializados no mercado interno e seus padrões de embalagem são mostrados na Tabela 1.2. 
Tabela 1.2: Tipo de açúcar e padrão de embalagem para o mercado interno

\begin{tabular}{ll}
\hline \multicolumn{1}{c}{ TIPO DE AÇÚCAR } & \multicolumn{1}{c}{ PADRÃO DE EMBALAGEM } \\
\hline Refinado Amorfo & $\begin{array}{l}\text { Saco de } 25 \text { ou } 30 \mathrm{~kg} ; \text { big bag até } 1200 \mathrm{~kg} ; \\
\text { a granel }\end{array}$ \\
\hline Refinado Granulado & Saco de 30 ou $50 \mathrm{~kg}$; big bag até $1200 \mathrm{~kg} ;$ \\
& a granel \\
\hline Cristal & Saco de $50 \mathrm{~kg} ;$ big bag até $1200 \mathrm{~kg}$ \\
\hline Demerara & Saco de $50 \mathrm{~kg}$ \\
\hline Líquido Simples & tambores de $200 \mathrm{~kg} ;$ a granel \\
\hline Líquido Invertido & tambores de $200 \mathrm{~kg} ;$ a granel \\
\hline
\end{tabular}

FONTES: Cosan, Copersucar, Crystalsev e Sindaçúcar (2004).

Além dos tipos de açúcar já mencionados para exportação, acrescentam-se no mercado interno os açúcares refinado amorfo, líquido sacarose e líquido invertido, cujas características e finalidades são:

- Açúcar refinado amorfo: é indicado para processos que exigem dissolução rápida. É obtido por um processo de refino do açúcar cristal e possui granulometria muito fina e irregular, além de baixa coloração;

- Açúcar líquido sacarose: é aplicado onde a ausência de cor é essencial, como produtos farmacêuticos, bebidas claras, balas e doces. É obtido pelo refino de açúcar cristal dissolvido em água declorada;

- Açúcar líquido invertido: é bastante utilizado na fabricação de frutas em calda, sorvete, balas, licores, geléias, biscoitos e refrigerantes. Trata-se de uma solução aquosa composta por glicose, frutose e sacarose, de aspecto claro, isento de odor e aromas.

Caixeta-Filho e Gameiro (2001) citam que o transporte no mercado interno é de responsabilidade da própria indústria compradora, já que é vendido FOT (free on truck 
ou posto/veículo/usina), ou seja, a responsabilidade do embarcador (usina ou tradings) vai até o momento em que o produto é posto sobre o caminhão, e quem arca com as despesas de transporte é a própria indústria.

Do ponto de vista do transportador, este mercado é mais bem estruturado do que o mercado de transportes para exportação, já que existe um maior número de agentes envolvidos. Assim, as indústrias não têm o mesmo domínio sobre as transportadoras, possibilitando a elas uma maior margem de negociação. Conseqüentemente, o frete cobrado para o transporte do açúcar no mercado interno é ligeiramente superior ao cobrado para o transporte destinado à exportação.

\subsection{Divisão da Matriz Modal Brasileira}

Como dito anteriormente, dada a contribuição das exportações do açúcar na balança comercial brasileira é importante que se busquem alternativas que tornem o produto cada vez mais competitivo no mercado externo. Dessa forma, as vantagens proporcionadas por um transporte de custos relativamente mais baixos podem propiciar um diferencial significativo sobre os custos totais que envolvem a comercialização do açúcar.

Diante desse contexto, atualmente há muita discussão sobre a divisão da matriz modal brasileira nas esferas política, empresarial, acadêmica e na própria sociedade. Popularizou-se o discurso de que a ferrovia brasileira é subutilizada e que, assim como nos países desenvolvidos, o transporte de granéis de alta densidade deveria ser feito por esse modo. No entanto, sabe-se também que, as condições da infra-estrutura ferroviária e a limitação dos portos quanto a absorção da demanda programada para os próximos anos (como o porto de Santos, por exemplo) tornam a ferrovia pouco atrativa para o empresário que necessita cada vez mais de eficiência no transporte para garantir valorização e credenciamento de seu produto no mercado externo. Por outro lado, é inevitável que o transporte porta-a-porta proporcionado pelo modo rodoviário se fortaleça, já que, grosso modo, basta haver caminhões disponíveis no mercado para que o serviço se realize. Além do mais, características como rapidez e flexibilidade tornam o modo rodoviário ainda mais competitivo, se comparado ao modo ferroviário. Em contrapartida, a tecnologia empregada pela maioria do mercado de frete para o setor de granéis de alta densidade é defasada em relação ao que já existe de novo no transporte 
de carga rodoviário, o que teoricamente onera os custos totais e incide diretamente no valor do produto.

Nesse sentido, discutem-se hoje na esfera política, alterações nas Resoluções nº 12 (Pesos e Dimensões) e 68 (Combinações de Veículos de Carga - CVCs) do CONTRAN. Tais alterações estão diretamente ligadas à operação das combinações que são objeto de estudo deste trabalho, no caso os bitrens de 7 e 9 eixos. Surge então o problema que motiva este estudo: é preferível transportar açúcar pela ferrovia, por um custo mais baixo, mas com uma operação limitada e deficiente, ou transportar açúcar pela rodovia, de operação mais flexível, mas que utiliza tecnologia defasada e que acaba por onerar os custos totais? Estudar as possíveis soluções para este problema e apresentá-las para todos aqueles envolvidos na discussão, justificam por si só a elaboração deste trabalho.

\subsection{Cenários no Transporte de Açúcar}

A investigação a que se propõe este trabalho visa comparar os custos de transporte referentes a dois cenários: o transporte rodoviário porta-a-porta, o qual apresenta quatro diferentes tecnologias de CVCs para o transporte de açúcar, e o transporte intermodal rodo-ferroviário utilizando terminais de transferência de carga. A seguir serão apresentadas as características gerais de ambos os cenários.

\subsubsection{Transporte rodoviário}

Neste cenário, o açúcar granel produzido pelas usinas, as quais estão posicionadas geograficamente em diferentes pontos do estado de São Paulo, é transportado diretamente até o porto de exportação, e pode ser embarcado em quatro possíveis combinações de veículos:

1. um semi-reboque basculante de 6 eixos (3S3) com capacidade máxima legal de carga da ordem de 30 toneladas (Figura 1.1);

2. um semi-reboque graneleiro convencional (2S3) com capacidade máxima legal de carga da ordem de 27 toneladas (Figura 1.2);

3. um bitrem graneleiro de 7 eixos (3S2B2) com capacidade máxima legal de carga da ordem de 37 toneladas (Figura 1.3); 
4. um bitrem graneleiro de 9 eixos (3S3B3) com capacidade máxima legal de carga da ordem de 45 toneladas (Figura 1.4).

A nomenclatura padronizada para as CVCs que será utilizada em toda essa pesquisa segue a proposta de WIDMER (2004), onde as letras tem relação direta com a descrição geral do veículo e tipo de conexão entre engates (a letra "S" significa semireboque e o "B” é uma conexão do tipo $\mathrm{B}$, por exemplo) e os números representam os eixos, ou conjunto de eixos.

Um aspecto importante a ser tratado diz respeito à estrutura de descarga do açúcar nos terminais e nos portos. No caso de unidades rebocáveis do tipo convencional (Figuras 1.2 e 1.4), há a necessidade de um sistema de elevação da combinação, denominado tombador (truck dumper, Figura 1.5). Já para unidades rebocáveis tipo Hopper (Figura 1.3), a descarga acontece por gravidade pelo fundo do implemento (Figura 1.3); e para o semi-reboque basculante (Figura 1.1), a própria inclinação da caçamba por meio de um conjunto hidráulico do veículo, permite o tombamento do açúcar por gravidade. Em todos esses casos apresentados, o local onde ocorre a descarga é denominado moega, a qual é uma estrutura de superfície vazada por onde o açúcar escoa antes de chegar às esteiras.

Após esta etapa, o açúcar a granel é transportado pelas esteiras para um armazém e aguarda até o embarque em um navio, o que em época de safra, pode ser da ordem de algumas horas.

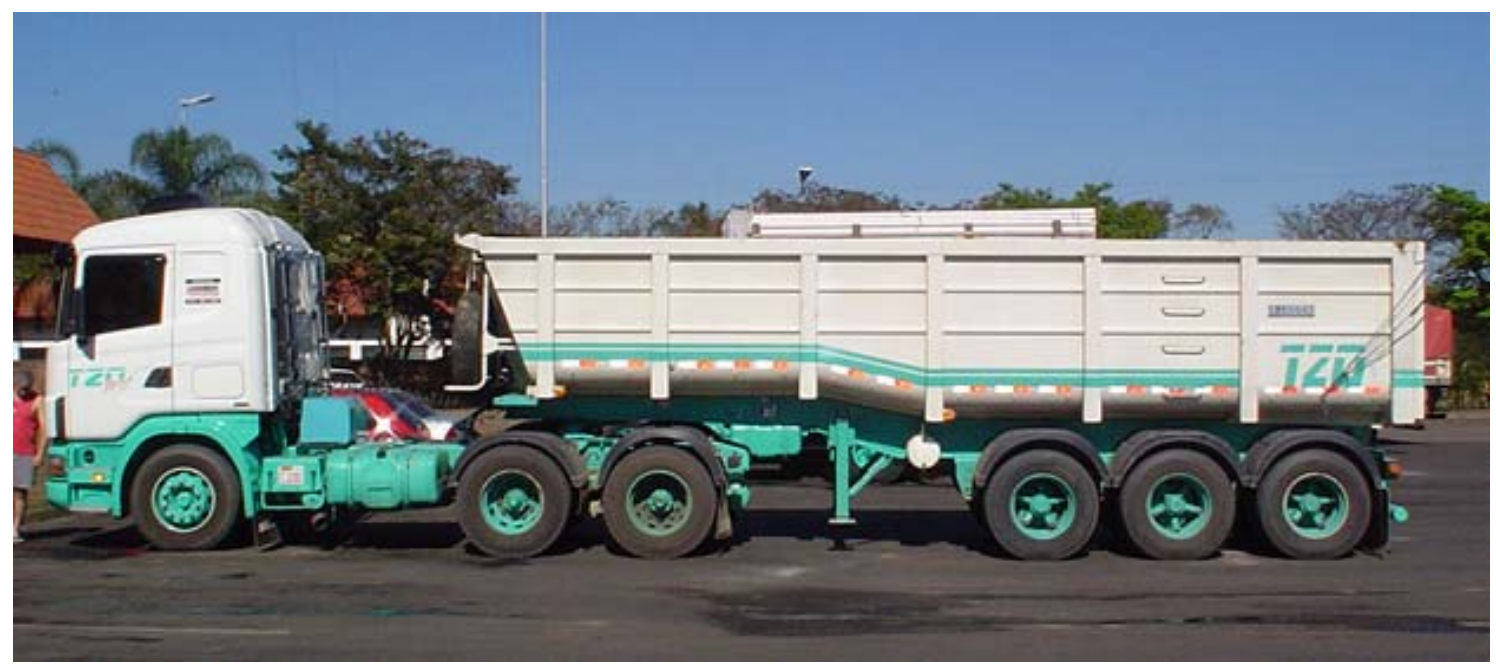

Figura 1.1: Semi-reboque basculante de 6 eixos (3S3). 


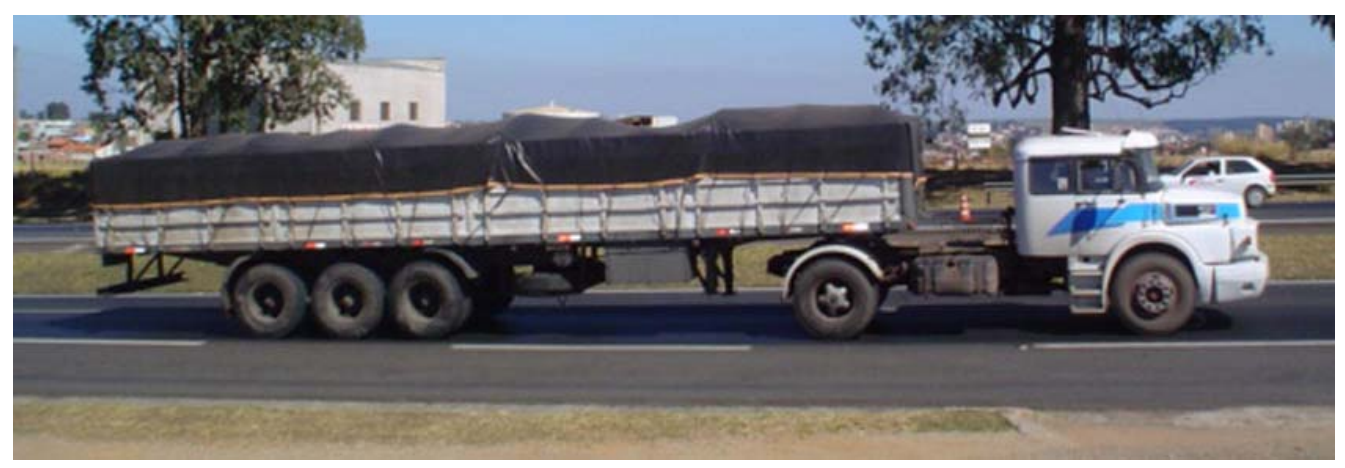

Figura 1.2: Semi-reboque convencional de 5 eixos (2S3).

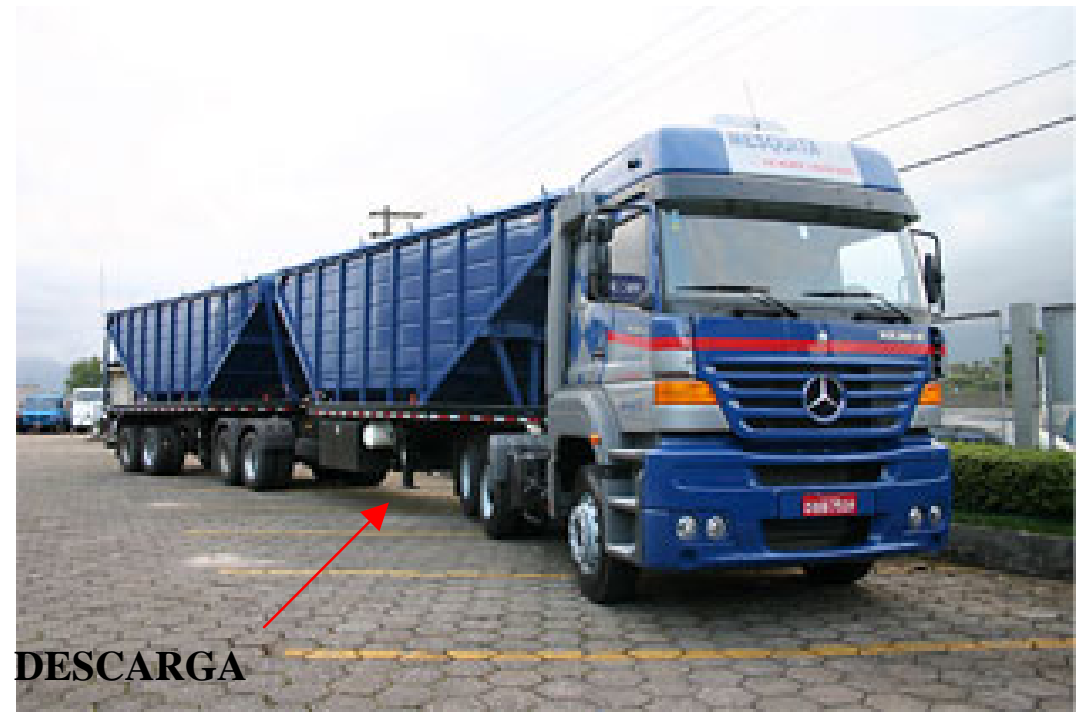

Figura 1.3: Bitrem de 7 eixos (3S2B2) tipo Hopper.

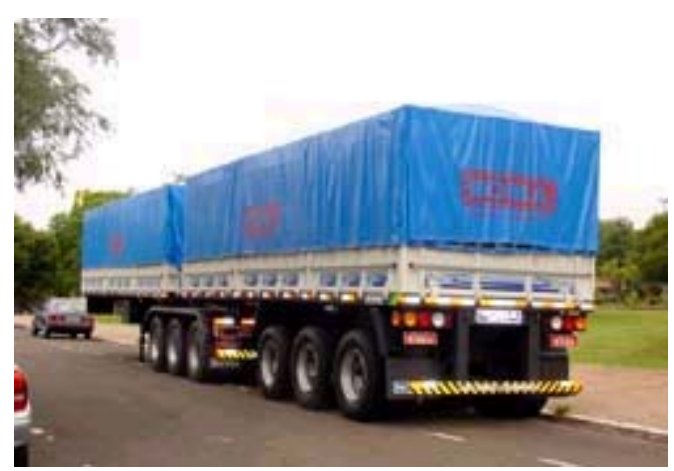

Figura 1.4: Implemento bitrem graneleiro convencional acoplável a um cavalo mecânico 6x4. 


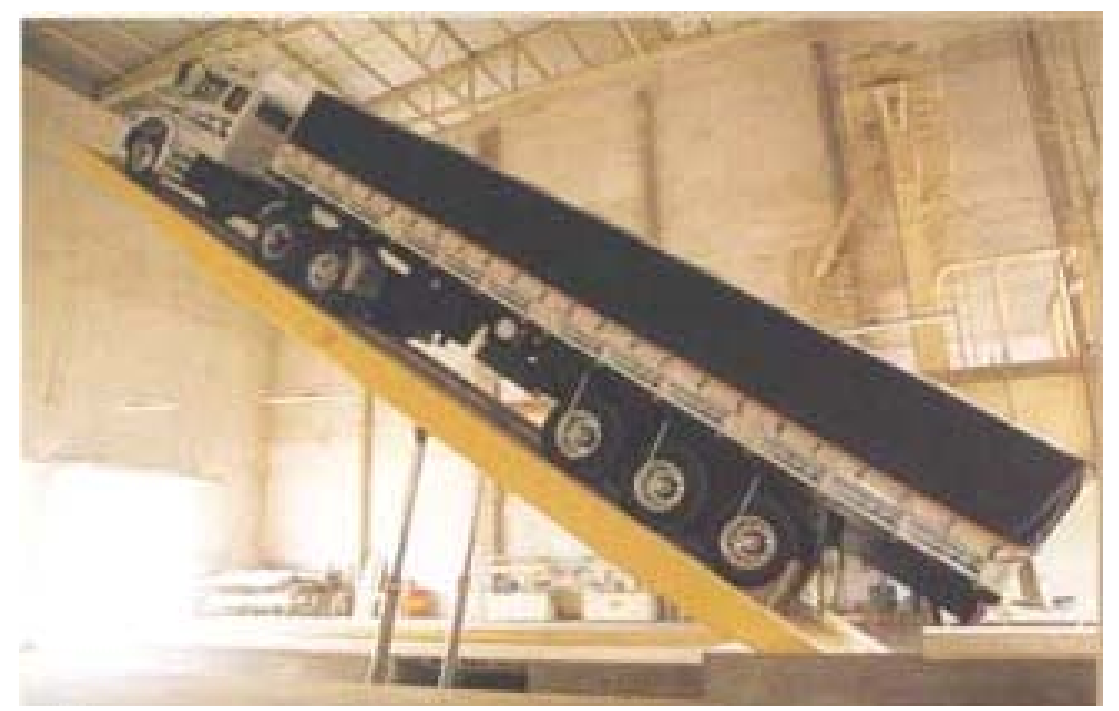

Figura 1.5: Semi-reboque graneleiro no tombador.

\subsubsection{Transporte rodo-ferroviário}

Nessa alternativa de transporte há uma associação do modo rodoviário, responsável pelo transporte do açúcar no percurso da usina ao terminal rodo-ferroviário, e do modo ferroviário, responsável pelo transporte do açúcar no percurso mais longo, desde o terminal rodo-ferroviário até o porto de exportação. No trecho rodoviário permanecem as alternativas de transporte apresentadas no primeiro cenário (2S3, 3S3, 3S2B2 e 3S3B3). No trecho ferroviário, os terminais intermodais selecionados estão localizados em diferentes posições geográficas no estado de São Paulo e são servidos por vias férreas de bitola larga $(1,60 \mathrm{~m})$ e estreita $(1,00 \mathrm{~m})$; no entanto, a rede ferroviária de São Paulo possui também trechos de bitola mista, onde trafegam ambas as bitolas. Os vagões de carga são do tipo FHD de 14,00 metros (Figura 1.6), com lotação de 60 toneladas cada. O carregamento dos vagões acontece por escotilhas localizadas na face superior do vagão; a descarga é feita pela abertura das tremonhas no fundo do vagão (Figura 1.7), diretamente sobre a moega ferroviária. Assim como no cenário anterior, o açúcar segue por esteiras da moega até o armazém, aguardando pelo embarque nos navios. 


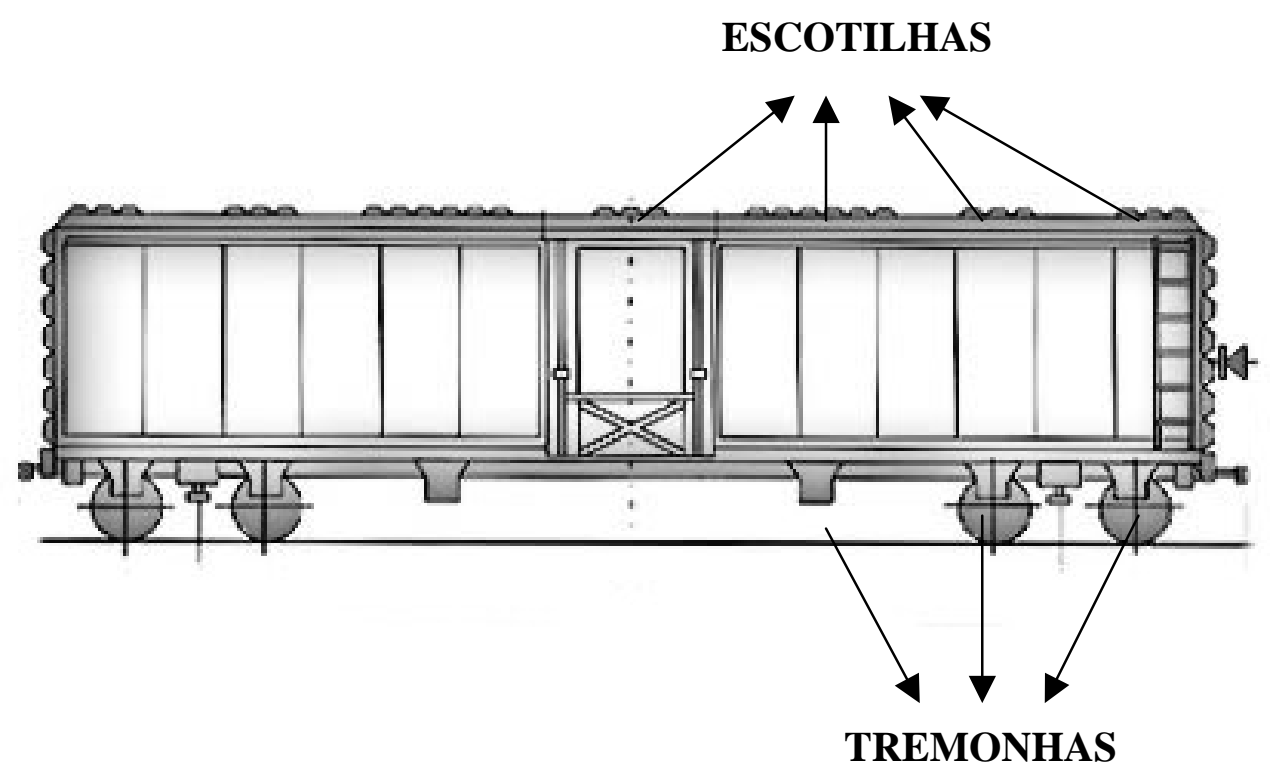

Figura 1.6: Vagão tipo FHD de 14,00 m. (vista lateral).

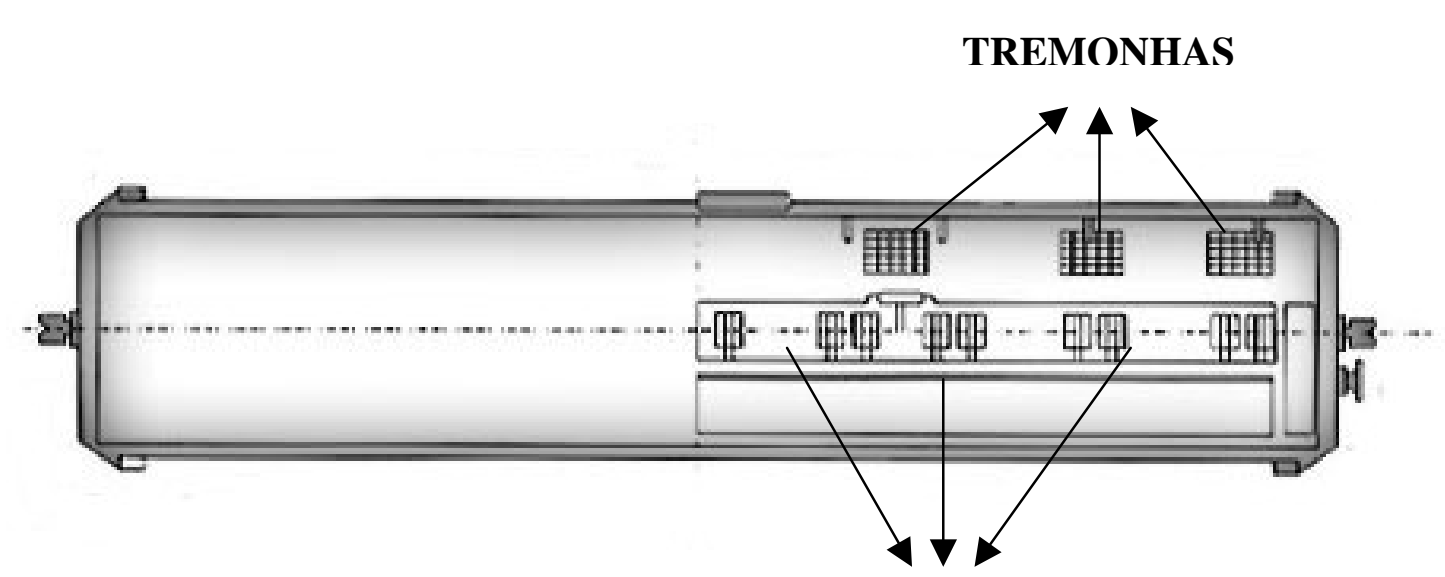

ESCOTILHAS

Figura 1.7: Vagão tipo FHD de 14,00 m. (vista de cima) 


\subsection{Objetivo da Pesquisa}

O objetivo dessa pesquisa é investigar as principais alternativas de transporte existentes para o açúcar a granel de exportação, e propor estratégias que orientem os agentes envolvidos neste mercado a racionalizar seus custos de distribuição.

Para isso, será conduzido um estudo de caso envolvendo um grupo de usinas que comercializam seus produtos em bloco, o qual representará o cenário do mercado de exportação de açúcar.

São criados três grupos de cenários que representam as principais alternativas de transporte neste setor:

- o rodoviário porta-a-porta;

- o rodo-ferroviário com restrição de capacidade de embarque de açúcar;

- e um cenário de longo prazo de transporte rodo-ferroviário sem restrição de capacidade de embarque de açúcar.

Em cada um desses grupos existe a opção de se transportar nos trechos rodoviários, tanto no porta-a-porta como nas pontas de acesso à ferrovia, com frota própria ou terceirizada. As alternativas tecnológicas rodoviárias investigadas nessa pesquisa são:

- Semi-reboque graneleiro convencional (2S3);

- Semi-reboque basculante (3S3);

- Bitrem graneleiro de 7 eixos (3S2B2);

- Bitrem graneleiro de 9 eixos (3S3B3).

As etapas preliminares necessárias para o cumprimento do objetivo principal são:

- Elaboração de um modelo baseado nos custos operacionais rodoviários e nos valores de frete cobrados para as usinas do estudo de caso;

- Elaboração de um modelo de custos rodo-ferroviários baseado nos fretes ferroviários (transporte e transbordo) e nos custos e fretes rodoviários;

- Simulação dos modelos elaborados com auxílio de um Sistema de Informação Geográfica e de planilhas eletrônicas; e

- Comparação dos custos econômicos das alternativas de transporte. 


\subsection{Organização da Dissertação}

A organização dos capítulos dessa dissertação reflete o método utilizado nessa pesquisa pelo seu autor:

- No Capítulo 1, apresenta-se o cenário escolhido como tema e identificam-se seus problemas e questões pertinentes, bem como se definem as justificativas e os objetivos da pesquisa;

- Nos Capítulos 2 e 3, apresentam-se os conceitos técnicos e as principais pesquisas relacionadas ao tema que embasam as conclusões do autor;

- Nos Capítulos 4 e 5 apresentam-se os instrumentos de auxílio à resolução dos problemas levantados, por meio da modelagem de custos e redes de transporte e suas aplicações em simulações de cenários;

- No Capítulo 6 fazem-se as análises e discussões dos resultados gerados pela aplicação dos modelos;

- No Capítulo 7 conclui-se a pesquisa e indicam-se novos temas que podem ser desenvolvidos a partir deste trabalho. 


\section{TRANSPORTE DE CARGAS}

Segundo Martins e Caixeta-Filho (1998) os transportes têm a função básica de proporcionar elevação na disponibilidade de bens ao permitirem o acesso a produtos que, de outra maneira, não estariam disponíveis para uma dada sociedade, ou o estariam apenas a um elevado preço; têm, assim, a função econômica de promover a integração entre sociedades que produzem bens diferentes entre si.

Com o propósito de proporcionar um transporte de carga eficiente e a menor custo, faz-se necessário entender os fatores geradores e influenciadores de sua demanda, bem como os aspectos técnicos, estruturais e organizacionais, que fazem com que os modos atuantes tenham vantagens e desvantagens num determinado segmento de mercado.

\subsection{Demanda por Transportes de Carga}

Embora o objetivo global do trabalho não seja apresentar modelos de demanda, os fatores que a caracterizam e influenciam são importantes para que os tomadores de decisões envolvidos nesse mercado façam as suas melhores escolhas. De uma forma geral, o conhecimento da demanda dá ao contratante de transportes a visão dos requisitos que ele espera de seu contratado.

O transporte de cargas é um componente vital da economia, pois esse dá suporte à produção, ao comércio, e às atividades de consumo, assegurando a movimentação eficiente e disponibilidade oportuna de matérias primas e bens de consumo. O transporte justifica uma parcela significativa dos custos finais dos produtos e representa uma componente importante nas despesas nacionais de qualquer país. (CRAINIC e LAPORTE, 1997).

O conceito básico da demanda por transporte é, segundo Kawamoto (1999), o desejo de uma entidade de locomover alguma coisa de um lugar para outro. Algumas citações conservadoras sobre o termo descrevem que sem atividades acontecendo na 
origem e no destino, o transporte perderia seu propósito e não aconteceria (BAMFORD, 2001). Conseqüentemente, o transporte é uma atividade que depende de outras atividades; uma atividade auxiliar bem como um serviço (RODRIGUE, 2004).

A princípio, Kanafani (1983) divide sua análise do fluxo de carga sob os pontos de vistas micro e macroeconômicos, e modelos de interação espacial. No entanto aqui, somente os conceitos atribuídos à análise microeconômica serão abordados, pois esses refletem melhor a realidade do objeto desta pesquisa.

Nessa análise, a unidade de decisão é a própria firma ou indivíduo envolvido em alguma atividade econômica. Essa firma pode ser a produtora de um determinado bem, para o qual necessita que suas matérias-primas sejam trazidas de um outro local. Ou ainda, essa firma pode ser uma revendedora de bens ou serviços que necessitam do transporte de cargas entre o local onde elas são produzidas e o local de revenda.

Na maioria das conceitualizações, a demanda por transporte de carga é rotulada como uma variável dependente, afetada por um conjunto de fatores complexos e interdependentes, cada um com seu respectivo peso (RODRIGUE, 2004). São eles:

- Economia;

- Estrutura espacial;

- Globalização;

- Acordos internacionais;

- Práticas de JIT (just in time) e armazenagem;

- Alianças estratégicas;

- Embalagem (empacotamento) e reciclagem;

- Custos dos combustíveis, taxas e subsídios;

- Infraestrutura e congestionamentos;

- Segurança e políticas ambientais;

- Tecnologia. 
Além desses fatores externos que influenciam a demanda pelo transporte de carga, faz-se necessário dar enfoque especial a escolha modal, uma vez que um dos objetivos deste trabalho é comparar modos de transportes num determinado setor da economia. Assim, sabe-se que diferentes modos de transporte estão disponíveis no mercado com diferentes níveis de serviço que afetam o custo do produto final. Portanto, a empresa deve concentrar seus esforços de forma a minimizar os custos generalizados de transporte e prover um serviço rápido e eficiente, seja pela opção de um determinado modo, ou pela harmoniosa integração entre modos, chamada de intermodalidade.

Para Woodburn (2003), tem havido muitas modificações proporcionadas pela logística que potencialmente afetam a escolha modal. Citam-se, por exemplo: mudança no local de atividade da empresa, na estrutura das redes de manufatura e distribuição, nas relações de mercado entre empresas, e no planejamento da produção e distribuição. Todas essas combinadas podem ser importantes fatores que influenciam a escolha modal no transporte de cargas.

Diversos autores complementam esse conceito com outros fatores que os influenciam (Krapfel e Mentzer, 1982; McGinnis, 1990; Murphy e Hall, 1995; Evers et al., 1996; Regan e Golob, 2000). São eles: os tempos de viagem, a confiança (variação no tempo de viagem), a probabilidade de perdas e danos à carga, a necessidade de embalagens especiais, a conveniência (por exemplo, a necessidade de se pegar uma carga no terminal versus um serviço porta-a-porta) e a disponibilidade para serviços especiais (refrigeração, ou água e ração para armazéns vivos). Uma decisão baseada nesses fatores apresentados, nas características do produto, e nas formalidades contratuais, dá ao tomador de decisão uma chance maior de acerto quanto à escolha modal.

Outro aspecto que tem ganhado importância na pesquisa sobre o assunto é a influência que a logística e a distribuição tem exercido sobre o conceito tradicional de demanda por transportes. Segundo alguns autores (RODRIGUE, 2004; MOKHTARIAN e SALOMON, 2001; CORTRIGHT, 2001), em um mundo globalizado onde as barreiras geográficas devem ser minimizadas, a distribuição não deve ser apenas uma variável dependente do processo econômico, e sim uma variável responsável pela moldagem da produção. Para Rodrigue (2004), isso implica que a 
distribuição passa a ser concomitantemente, um fator derivado e também indutor na demanda pelo transporte de carga.

Essa observação ganha sentido no cenário brasileiro uma vez que se observa uma infra-estrutura de transportes, em sua maioria, precária e de grandes limitações. Nos últimos anos, os recordes da produção agrícola brasileira tem sido batidos sucessivamente, assim como as exportações de commodities. Em alguns anos, quando a infra-estrutura brasileira não for mais capaz de escoar nem armazenar o que for produzido, veremos o que está sendo prenunciado atualmente como “apagão logístico”. A partir desse momento, se não houver expansão e melhora da infra-estrutura de transportes brasileira, a produção passará a ser moldada e restringida em relação ao sistema de distribuição existente.

\subsection{Aspectos Sobre o Transporte Rodoviário de Cargas Utilizando CVCs}

Segundo Schroeder e Castro (2002), a opção pela modalidade rodoviária como principal meio de transporte de carga é um fenômeno que se observa a nível mundial desde a década de 50, causado pela expansão da indústria automobilística e pelos baixos preços dos combustíveis derivados do petróleo. Desde então, percebeu-se neste mercado, a busca incessante por tecnologias que aumentem a produtividade, baixem os custos operacionais, e aumentem a satisfação de seus usuários.

A introdução das CVCs no mercado de transporte de carga rodoviário reflete exatamente essa busca preconizada. A combinação de veículo de carga (CVC) é definida como qualquer veículo de carga que não seja unitário (FILGUEIRAS et al., 2004). De acordo com diversas publicações pesquisadas por Widmer (1990), depreendese que pressões econômicas e políticas do mercado em meados da década de 70 forçaram a operação limitada dessas combinações em alguns Estados norte-americanos, canadenses e australianos. As principais vantagens dessas combinações são: os relativos ganhos na capacidade volumétrica, gerado pelo aumento de suas dimensões, no transporte de carga fracionada de alto valor agregado; e o aumento capacidade de carga para granéis sólidos e líquidos, os quais possuem baixo valor agregado (WIDMER, 2002). 
Durante a última década, portanto, muitas pesquisas foram conduzidas com o intuito de fornecer embasamento técnico para que houvesse uma regulamentação adequada quanto à utilização das CVCs. É o caso dos estudos conduzidos pelo Transportation Research Board (TRB, 1990a; TRB 1990b) e pelo Department of Transportation dos Estados Unidos (DOT, 1995a; DOT, 1995b; DOT, 2000) os quais investigam e propõem regulamentações quanto aos pesos e dimensões das combinações que trafegam nas rodovias americanas. Segundo Clarke (1999), os principais temas abordados por essas pesquisas podem ser resumidos em:

- Custos e efeitos do aumento individual da carga por eixo nos pavimentos e obras de arte;

- Efeitos da interação entre a configuração do veículo, a geometria das vias e as operações de tráfego;

- Métodos que analisam o efeito em situações dinâmicas de estabilidade (e segurança, conseqüentemente), de vários projetos de configurações, espaçamento entre eixos, pesos específicos e solicitações de carga;

- Impactos e conseqüências sobre outros modos de transporte gerados pela migração de cargas para o modo rodoviário; e por fim

- A opinião pública sobre dividir as rodovias com combinações maiores e mais pesadas.

No Brasil, os pesos e dimensões dos veículos de carga são regulamentados pelo Código de Trânsito Brasileiro, do Conselho Nacional de Trânsito (BRASIL, 1999a). A Resolução $\mathrm{n}^{\mathrm{0}} 12$ de 06 de fevereiro de 1998 descreve a lei que estabelece os limites de peso por eixo, comprimento e largura que transitam por vias terrestres (BRASIL, 1999b). Essa lei prevê que para CVCs de comprimentos entre 19,80 e 30,00 metros, há necessidade de utilização de Autorização Especial de Trânsito, descrita na Resolução ${ }^{\circ}$ 68 de 23 de setembro de 1998 (BRASIL, 1999c). No entanto, recentemente, a Resolução $n^{\circ} 164$ de 10 de setembro de 2004 acresce à Resolução no 68 que ficam dispensados da AET os veículos com Peso Bruto Total Combinado (PBTC) superior a 45 toneladas e até 57 toneladas, desde que esses possuam máximo de 7 eixos, comprimento máximo de 19,80 metros e mínimo de 17,5 metros, unidade tratora do tipo cavalo mecânico, e acoplamento com pino rei e quinta roda (BRASIL, 2004). 
Perdura ainda a discussão sobre outras alterações na Resolução ${ }^{\circ} 68$ envolvendo CVCs do tipo bitrens de 9 eixos. As mudanças planejadas pela Associação Nacional do Transporte de Cargas e Logística (NTC) entre outras são (REIS, 2003):

- Liberação de CVCs com tandem triplo de forma a se permitir o uso de bitrens de 9 eixos, 74 toneladas e 25 metros, não previstos na Resolução nº 68;

- Permitir a circulação diuturna dessas CVCs em qualquer rodovia brasileira.

Os fundamentos dessas modificações nas regulamentações brasileiras podem ser encontrados em Widmer (2002) e Reis (2003), os quais seguem basicamente os mesmos preceitos apresentados por Clarke (1999):

- Impacto sobre obras de artes: segundo relatório do DER-SP (2001), as CVCs de 9 eixos até 25 metros, tanto os rodotrens quanto os bitrens, são compatíveis com as pontes classes 36 e 45;

- Impacto sobre o pavimento: de acordo com critérios da AASHTO encontrados em Pereira (1992), o fator equivalente de carga por tonelada das CVCs de 9 eixos são inferiores aos de semi-reboques convencionais de 6 eixos, especialmente para os bitrens de 25 metros;

- Segurança: a estabilidade das conexões tipo B são comprovadamente mais seguras do que as do tipo A utilizada nos rodotrens (DOT, 2000), os quais já são previstos pela Resolução $n^{\circ} 68$;

- Cruzamentos: baseado num modelo de simulação de Machado Neto e Setti (1994), observa-se que o acréscimo de 5 metros no comprimento máximo das combinações resulta de 1 a 5 segundos a mais no tempo de ultrapassagem em média. No entanto, não há levantamentos estatísticos de tentativas de ultrapassagem envolvendo CVCs que comprovem a incidência dos mesmos em função do acréscimo de comprimento das combinações. Em contrapartida, é sabido que no Canadá os condutores se habituaram a identificar as CVCs e as aceitam no trânsito sem restrições;

- Cruzamentos em interseções: a partir de um estudo de Demarchi (1995) observa-se que combinações mais longas necessitam de uma maior distância de visibilidade em acessos e cruzamentos. Uma solução que amenizaria este 
problema seria a imposição legal de unidades tratoras com relações maiores de potência/peso nas CVCs, o que também influenciaria positivamente no aumento da velocidade de equilíbrio nos aclives;

- Sobrelargura e arrasto em curvas: segundo estudos da USP São Carlos, o arrasto em curvas dos bitrens de 9 eixos e 25 metros é ligeiramente inferior a composições que têm tráfego livre atualmente em todas as rodovias brasileiras (cavalo mecânico 4x2 tracionando semi-reboque de um eixo e 18,15 metros) (WIDMER, 2002).

Apesar de existirem argumentos técnicos favoráveis que respaldam a operação do bitrem de 9 eixos de 25 metros, não há ainda previsão para que essa combinação tenha sua utilização regulamentada, pois ainda não há entendimento entre os órgãos reguladores (TRANSPORTE MODERNO, 2003). Na esfera pública, tal impasse acontece porque segundo o Ministério dos Transportes, o DENATRAN (órgão com o qual as questões têm sido discutidas) não tem competência para emitir AETs. Essa competência cabe ao DNIT - Departamento Nacional de Infra-Estrutura em Transportes, o qual avaliará a inclusão do bitrem de 9 eixos e 25 metros na Resolução ${ }^{\circ}$ 68, a partir de relatórios operacionais elaborados pelos beneficiados de autorizações provisórias, concedidas enquanto a combinação estava em caráter experimental (REIS, 2003).

Ao que parece, deverá acontecer, por analogia aos casos da América do Norte, Austrália, e do próprio bitrem de 7 eixos recentemente no Brasil, uma forte pressão econômica e política pela regulamentação do bitrem de 9 eixos e 25 metros, como prenunciado por Widmer (1990) no início da década de 90. As pesquisas sobre os impactos de sua utilização devem, portanto, continuar a ser tema de diversas pesquisas, especialmente as que abordam os parâmetros de custos operacionais e divisão modal numa nova realidade tecnológica rodoviária. 


\subsection{Estratégias Aplicadas ao Modo Ferroviário para Obter Maior Inserção no Mercado de Transporte de Cargas}

Segundo Martins e Caixeta-Filho (1998), as ferrovias desempenharam importante contribuição ao desenvolvimento econômico de grande parte das nações no século XIX, devido ao fato de terem preenchido a lacuna deixada pelo transporte hidroviário, que não conseguia movimentar cargas pesadas a grandes distâncias e apresentava dificuldade para suplantar barreiras naturais.

Mesmo passados quase dois séculos desde sua criação, o transporte ferroviário de carga ainda é tema de muitas pesquisas visto que, após vários períodos de crises diversas por todo mundo, destacando-se, por exemplo, a concorrência com o modo rodoviário, a sua participação no transporte intermodal é fundamental para os objetivos do mercado globalizado, o qual busca eficiência, confiabilidade e rapidez a custos cada vez menores.

Sob este aspecto, Takahashi et al. (2001) destacam que as ferrovias, por apresentarem custos fixos altos e custos variáveis relativamente baixos, quando bem planejadas e operadas, representam interessante alternativa no transporte de elevadas quantidades de carga. Segundo Krüger (2003), os pontos fortes potencias do transporte ferroviários são:

- Maior capacidade de transporte;

- Menor consumo energético;

- Menor espaço físico;

- Possibilidade de automação;

- Maior segurança;

- Menor poluição;

- Integração com outros modos;

- Rendimento crescente;

- Menor custo social de produção. 
No entanto, há de se destacar principalmente quais são as dificuldades que o transporte ferroviário vem apresentando para assumir esse papel no transporte intermodal, para que dessa forma, os esforços realizados pelos órgãos reguladores e as empresas envolvidas tenham maior efetividade.

Para entender as atuais necessidades do transporte ferroviário deve-se remeter aos anos 80 quando alguns dos mais importantes países do mundo passaram por processos de desestatizações do sistema ferroviário. A crise do petróleo na década de 70, o excesso de pessoal, a falta de capacidade de investimentos do setor público e a existência de dívidas crônicas, fizeram com que países como os Estados Unidos, Inglaterra, Japão, Suécia, Alemanha, Espanha e França, promovessem a desregulamentação e privatização do setor, com o objetivo de torná-lo um modo eficiente e competitivo (MARTINS e CAIXETA-FILHO, 1998).

De fato, a medida teve efeito positivo, pois segundo Resor e Thompson (1999), foi a partir da desregulamentação que as grandes fortunas dos investidores em transporte ferroviário se formaram. Isso se deveu a duas posturas basicamente: melhora expressiva da operação, manutenção das vias, confiabilidade e segurança no transporte ferroviário; e o abandono de milhares de quilômetros de vias com o intuito de reduzir custos de manutenção e pessoal. Para Resor e Thompson (1999), o resultado desta segunda postura tem sido um dos principais fatores da limitação da capacidade de carga no transporte ferroviário americano.

Tal situação é análoga ao cenário brasileiro de transporte de carga. Segundo Castro (2002), a privatização de serviços de transporte avançou com inegável êxito nos últimos anos. No caso do setor ferroviário, as realizações de destaque incluem o desmanche das onerosas organizações que operavam e administravam o sistema, e os ganhos significativos de produtividade obtidos pelas concessionárias privadas (CASTRO, 2002). A continuidade desse processo, no entanto, exige uma reflexão aprofundada sobre as reais possibilidades da ferrovia vir a desempenhar um papel de destaque na matriz modal brasileira, a qual corresponde hoje por cerca de $20 \%$ de toda a movimentação de carga brasileira, contra aproximadamente $60 \%$ do modo rodoviário, 13\% do aquaviário, 5\% do dutoviário e 1\% do aeroviário (CNT, 2002).

Diversos fatores influenciam para que o transporte ferroviário de carga brasileiro tenha limites de capacidade de transporte. Segundo Ramos e Widmer (2003) os 
problemas estruturais e conjunturais das ferrovias brasileiras são decorrentes de seu processo histórico de construção. Castro e Lamy (1994) ainda complementam que o gerenciamento estatal que perdurou até a privatização na década de 90 também teve sua contribuição para o atual estado da infra-estrutura ferroviária.

Martins e Caixeta-Filho (1998) destacam primeiramente, o fator operacional limitante referente à diversidade de bitolas na malha nacional. Enquanto nos antigos sistemas Nordeste e Sul da RFFSA predomina a bitola métrica, nos demais, São Paulo e Centro (também da RFFSA), são encontradas bitolas métrica e larga. Isso decorre da construção descoordenada do final do século XIX, quando se possibilitava a particulares construir ferrovias sem prévio enquadramento em objetivos nacionais, guiados apenas por suas próprias necessidades.

De uma forma geral, Ramos e Widmer (2003) destacam ainda que além de antigas e encontrarem-se em situação precária, as linhas férreas atravessam áreas habitadas (ou invadidas), limitando ainda mais a velocidade dos trens e induzindo acidentes.

Para exemplificar o problema de infra-estrutura ferroviária quanto à troca de bitola e a transposição de áreas ocupadas, Castro (2002) aborda a atual situação da malha do Estado de São Paulo, mais especificamente o grande centro de convergência das malhas da ALL, Ferronorte, Novoeste, MRS e FCA no espaço geográfico que engloba a região de São Paulo, Campinas, Santos e adjacências, maior centro econômico do Brasil, e interligado ferroviariamente em todas as direções.

Neste caso, a malha que serve à Região Sul do país é de bitola métrica (ALL), e ao chegar à região de transposição (Região Metropolitana de São Paulo - RMSP), a qual antecede o acesso ao Porto de Santos, se conecta aos subsistemas que servem à Região Centro-Oeste, Triângulo Mineiro e Goiás em bitola métrica (Novoeste e FCA), e de novo à Região Centro-Oeste e Sudeste em bitola larga (MRS e Ferronorte). Essa transposição Sudeste - Sul, Sul - Sudeste se dá então na RMSP, obrigando a utilização de linhas congestionadas pelo tráfego de trens de passageiros, que têm prioridade sobre o tráfego de cargas. Isso cria uma barreira concreta para o desenvolvimento de serviços de transporte ferroviário que cruzem o maior pólo industrial do país (CASTRO, 2002).

Como solução para esse problema de convergência de concessionárias que atuam em bitolas diferentes numa região metropolitana de grande tráfego de trens de 
passageiros, o Plano Diretor de Transportes do Estado de São Paulo (PDDT, 2000) prevê a construção de um ferroanel no perímetro da RMSP o qual permitirá superar o gargalo de transposição da região, o qual deverá ser complementado ainda por modernos terminais de integração modal em seu entorno (CASTRO, 2002).

Após a transposição da Região Metropolitana de São Paulo, outro gargalo ferroviário surge no próprio Porto de Santos: o acesso às margens do estuário, as quais estão sob concessão da MRS. Pelos contratos vigentes, a MRS deve conceder tráfego mútuo em sua linha para as composições de outras concessionárias, sobre o qual incide uma cobrança de tarifas extras pelo serviço; ou em caso de impossibilidade, permitir direito de passagem. Nesse contexto, as concessionárias que necessitam do acesso ao trecho reclamam da improdutividade gerada pelas longas esperas para trafegar no trecho e das altas taxas cobradas no tráfego mútuo . Por sua vez, a MRS está respaldada pelo contrato firmado com o Governo Federal no processo de privatização, portanto, está em seu pleno direito. A solução para o conflito, recém encaminhada pela Agência Nacional de Transportes Terrestres (ANTT), está na construção de um novo trecho de acesso ao Porto de Santos (GAZETA MERCANTIL, 2004), sem que haja prejuízo e desrespeito ao contrato da MRS, mediante a permuta de ativos entre a concessionária e a holding Brasil Ferrovias, maior interessada na solução do problema.

No entanto Castro (2002) ainda discute um outro fator limitante ao desenvolvimento do transporte ferroviário, não mais de ordem estrutural, e sim de ordem institucional. O questionamento a ser feito é: quem de fato deve ser o responsável pela construção, financiamento e operação desses empreendimentos necessários? Isso porque há diversos interessados nesses projetos, por exemplo: Estados servidos por essas ferrovias, municípios, concessionárias ferroviárias, portos e operadores portuários, o próprio Governo Federal, entre outros. Mesmo com essa dificuldade para se estabelecer um ordenamento dos interesses, sabe-se que esse não se trata de um mercado de soma final nula, dada as possibilidades de crescimento do setor, conseqüentemente, todos os agentes envolvidos (públicos ou privados) só teriam a ganhar.

Finalmente, Krüger (2003) faz menção ao problema de desigualdade de tratamento e atendimento a pequenos clientes no mercado de transporte ferroviário. Isso nada mais é do que o reflexo de todos os problemas estruturais levantados até aqui. Ou 
seja, as concessionárias por apresentarem uma estrutura limitada, e ao mesmo tempo, metas a serem cumpridas e apresentadas às agências reguladoras do Governo Federal, são obrigadas a venderem seus serviços àqueles que podem oferecer um melhor preço e durante um período maior. Infelizmente não se podem crucificar as concessionárias por tal atitude, pois elas estão atuando dentro de um regime de mercado onde quem pode pagar mais tem preferência pelo transporte, visto que este tem uma limitação. Castro et al. (1997) ainda ressaltam que a presença de usuários cativos do transporte ferroviário (mineradoras e siderúrgicas) no comando acionário das principais concessões ferroviárias brasileiras, também contribui para essa desigualdade de tratamento.

Como solução para esse problema, alguns produtores e empresas que demandam esse serviço, já se dispõem a investir em vagões e terminais intermodais com intuito de serem atendidos pelas concessionárias ferroviárias. No entanto, nem todos são capazes de financiar estes investimentos e tal fato não pode passar desapercebido, uma vez que nessa demanda por transportes reside um grande potencial de expansão para o modo ferroviário.

\subsection{Estrutura de Formação dos Custos dos Fretes no Transporte Rodoviário e Ferroviário de Cargas}

Um tema que tem sido amplamente discutido nos últimos tempos remete à competição entre os custos dos fretes entre os modos rodoviário e ferroviário de cargas. Segundo Fleury et al. (2000), cada modo, em função de suas características, possui uma vocação específica para o deslocamento de alguns tipos de produtos. No Brasil, no entanto, percebe-se através da análise da matriz modal de transportes um grande desequilíbrio entre os modos, decorrente do uso intensivo do modo rodoviário. No transporte de açúcar a granel, por exemplo, o qual é um produto de baixo valor agregado e grande fluxo de movimentação, é possível perceber a maciça participação do modo rodoviário ao invés do ferroviário.

Em parte, isso se deve à baixa disponibilidade da ferrovia para o transporte de açúcar, que em boa parte do ano encontra-se ocupada com outras commodities (geralmente a soja e seus derivados), provenientes da Região Centro-Oeste do país (item 2.3). Por outro lado, a presença de fretes rodoviários cada vez mais competitivos frente 
aos ferroviários, faz desse modo de transporte a principal forma de exportação do açúcar a granel brasileiro durante as safras.

Segundo Uelze (1974), no Brasil o mercado do transporte rodoviário de carga tende à concorrência perfeita. Isto se explica pela inexistência de qualquer dispositivo regulatório, tanto em nível federal quanto estadual, que controle a entrada e saída de profissionais autônomos e empresas do mercado; que exija requisitos mínimos para licenciamento da atividade; ou que disponibilize tabelas referenciais que induzam a um valor mínimo para fretes. Para Moreira e Ratton Neto (2003), enquanto a ferrovia, concedida, possui metas a cumprir e é regulamentada e regulada, o transporte rodoviário é apenas monitorado. Ou seja, existem dentro de um mercado livre, modos com diferentes formas de tratamento pelo poder público.

Essa situação fatalmente afeta a concorrência interna no modo rodoviário (entre empresas de transporte de carga - ETC e transportadores comerciais autônomos TCA), bem como entre os outros modos de transporte. Nesse contexto, Danilevicz et al. (2003) fazem uma extensa argumentação de que os maiores prejudicados nesse mercado são os transportadores autônomos.

No caso dos transportadores autônomos, a capacidade técnica limitada e a falta de estrutura de apoio ao cliente na prestação de serviços restringem significativamente o acesso ao transporte de mercadorias de valor agregado elevado, cujo preço dos fretes é maior. Resta então, o transporte de mercadorias de valor agregado mais baixo, onde existe uma grande pressão por parte dos embarcadores (fabricantes, atacadistas, varejistas) no sentido de reduzir o valor dos fretes.

Aliadas a esta situação estão os avanços de produtividade alcançados pelos modos ferroviário e hidroviário (especialmente após a privatização das ferrovias) e a crescente massa de desempregados provenientes de outras áreas da economia que proporcionam um aumento na oferta de transportes.

Por fim, Danilevicz et al. (2003) analisam índices de insatisfação quanto a fatores que influenciam a prestação de serviço dos transportadores autônomos. Destacou-se por ordem de prioridade: o preço dos combustíveis, o preço de pneus e peças de manutenção, o preço dos pedágios e o baixo retorno financeiro do transporte de cargas. Em contrapartida, menor insatisfação foi demonstrada aos fatores: financiamentos 
acessíveis para a renovação da frota e isenção fiscal para aquisição de frota. Esses fatores em conjunto explicam a existência de tarifas de fretes baixas, suficientes apenas para arcar os custos operacionais e manter uma margem mínima de retorno, bem como justifica a existência de uma frota de veículos de carga antiga e sem presença maciça de novas tecnologias, como os bitrens, por exemplo, que contribuem para o aumento da produtividade e diminuem os custos unitários.

No transporte ferroviário a maior crítica quanto a sua tarifação decorre do não cumprimento da Lei 8.987/95, a qual proíbe a prática de preços predatórios, evitando concentrações indevidas de mercado, assim como a discriminação de usuários e de outros operadores, salvo em decorrência de características técnicas e de custos específicos (BRASIL, 1995). Castro et al. (1997) reforçam que essa é uma prática corrente nas concessionárias ferroviárias, uma vez que os custos comuns aos usuários são de difíceis divisões, conseqüentemente, há uma padronização de tarifas, o que acaba sendo a maior fonte de cobertura dos custos dessas empresas.

Castro et al. (1997) justificam que essa prática é possível de acontecer, pois existem brechas na Lei 8.987/95 que não especificam claramente o método de cálculo de custos ferroviários, havendo apenas uma tabela de referência apresentando as tarifas. A tarifa máxima é estipulada em relação a essas referências; as tarifas mínimas devem ser calculadas em função de custos variáveis de longo prazo, os quais também não são devidamente determinados por métodos de cálculo. Por fim, em caso de divergência quanto à tarifa estipulada, entre o prestador de serviço e os usuários cativos, cabe ao Poder Concedente definir o valor. No entanto, não há definição clara do significado de usuário cativo.

Embora essa prática possa ser considerada abusiva para alguns usuários, é ela que abre espaço para que haja concorrência do modo ferroviário com o modo rodoviário em termos tarifários. Pois, considerando a flexibilidade dos transportadores rodoviários, certamente a concorrência encontrará nesse nicho campos férteis para conquistar fatias desse mercado (CASTRO et al., 1997). 


\section{FLUXO EM REDE E APLICAÇÃO EM SIGs}

Neste capítulo serão apresentados os conceitos básicos referentes aos fluxos em rede. Isso é importante para entender o princípio de funcionamento das chamadas "caixas pretas" que acompanham os solvers dos softwares disponíveis para a solução dos clássicos Problemas do Transporte e do Caminho Mínimo. Essas serão as técnicas executadas pelo programa escolhido nesta pesquisa (SIG-T TransCAD) para otimização dos fluxos e custos na rede de transporte rodoviário do estudo de caso (capítulo 5).

Além disso, exemplos diversos de aplicações dos Sistemas de Informação Geográfica na Engenharia de Transportes encontrados na literatura serão apresentados.

\subsection{Grafos e Redes de Transporte}

Os grafos constituem uma técnica extensivamente aplicada para a solução de alguns algoritmos de programação matemática, como por exemplo, o Problema de Transporte e o da Atribuição (NOVAES, 1978).

Segundo a terminologia da teoria dos grafos, citada por Hillier e Lieberman (1988), um grafo consiste num conjunto de pontos de junção chamados de nós, com certos pares de nós unidos por linhas chamadas de ramos (ou arcos, ou ligações, ou arestas). A Figura 10 exemplifica a forma de um grafo.

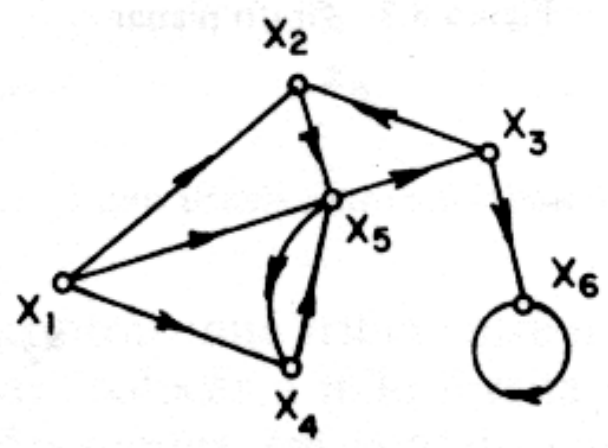

Figura 3.1: Exemplo de grafo (NOVAES, 1978). 
Uma rede é considerada um grafo com um fluxo de algum tipo em seus ramos. Já uma rede de transporte, segundo Novaes (1978), é um grafo finito, sem voltas, ou seja, não há arcos ligando um nó a si mesmo, tal que:

a) A cada arco $u_{i}$ é associado um número $W\left(u_{i}\right) \geq 0$, denominado capacidade do arco;

b) Existe apenas um nó $F$, chamado fonte, a partir do qual saem somente arcos efluentes (isto é, com sentido do nó para fora);

c) Existe apenas um nó $Z$, denominado dreno, ao qual chegam somente arcos afluentes.

A seguir é apresentado um exemplo de uma rede de transporte (Figura 11).

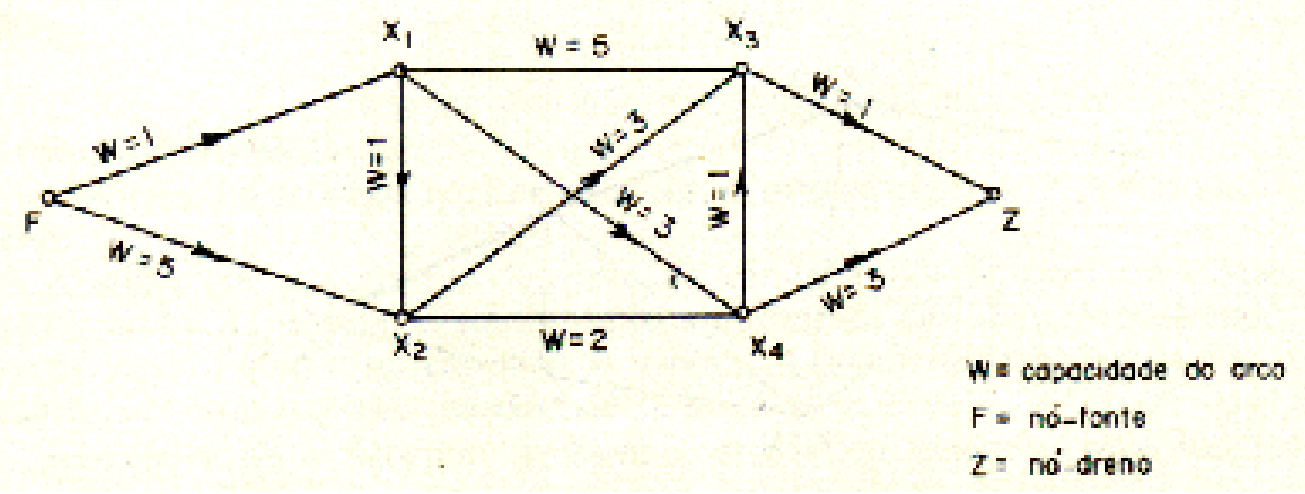

Figura 3.2: Exemplo de uma rede de transporte (NOVAES, 1978).

E ainda, a cada arco $u_{i}$ associa-se um número inteiro, denominado fluxo $\phi\left(u_{i}\right)$, tal que:

a) $\phi\left(u_{i}\right) \geq 0$

b) $\phi\left(u_{i}\right) \leq W\left(u_{i}\right)$

c) o fluxo total que entra num nó deve ser igual ao fluxo total emergente desse nó, a exceção da fonte e do dreno.

Alguns problemas são básicos na aplicação da teoria das redes, geralmente aqueles relacionados ao estudo dos sistemas de transporte, como por exemplo, encontrar a rota mais curta numa rede, minimizar a distância total de conexões, maximizar o fluxo na 
rede, e também planejar e controlar projetos relacionados às técnicas de PERT (Program Evaluation and Review Techique) e CPM (Critical Path Method).

\subsection{Programação Linear}

Segundo Novaes (1978), a programação linear é uma técnica utilizada para resolver determinada classe de problemas em que se procura alocar recursos limitados a atividades ou decisões diversas, de maneira ótima. Hillier e Lieberman (1988) citam ainda que esses problemas de alocação referem-se tipicamente a atividades em competição. Esses problemas aparecem com freqüência nos setores de planejamento e operação de indústrias, empresas de transporte, órgãos governamentais, entre outros, sendo a programação linear talvez a técnica de pesquisa operacional mais difundida e utilizada nas suas diversas formas.

Para de Neufville e Stafford (1971), as técnicas de programação matemática tiram vantagem da capacidade dos computadores por executarem cálculos simples extremamente rápido. Isso se deve a duas estratégias fundamentais: a primeira é utilizar o escalonamento similar ao procedimento da análise marginal; a segunda é enumerar todas as possíveis combinações de variáveis e selecionar a melhor entre elas. De uma maneira geral, a programação linear apresenta-se da seguinte forma matemática:

- Função objetivo: representa a variável principal $(Z)$ que deseja-se otimizar. Nos casos de maximização representam geralmente a receita monetária, lucro, benefícios, etc; na minimização representam custos ou benefícios negativos.

- $\quad \max$ ou $\min Z=c_{1} x_{1}+c_{2} x_{2}+\ldots+c_{n} x_{n}$

- Restrições: limitações físicas, de recursos humanos, monetários, socioeconômicos, etc.

$$
\begin{aligned}
& a_{11} x_{1}+a_{12} x_{2}+\ldots+a_{1 n} x_{n} \leq b_{1} \\
& a_{12} x_{1}+a_{22} x_{2}+\ldots+a_{2 n} x_{n} \leq b_{2} \quad \text { e mais } \\
& \mathrm{M} \\
& a_{m 1} x_{1}+a_{m 2} x_{2}+\ldots+a_{m n} x_{n} \leq b_{m} \\
& \operatorname{com} i=1,2, \ldots, m, \mathrm{e}
\end{aligned}
$$




$$
\begin{aligned}
& j=1,2, \ldots, n \\
& \text { - } \quad x_{i} \geq 0 \text { para } i=1,2, \ldots, m
\end{aligned}
$$

Sendo que $a_{i j}, b_{i}$ e $c_{i}$ são constantes e os $x_{i}(i=1,2, \ldots, m)$ são variáveis do tipo decisão.

\subsubsection{O Problema do Transporte e do Caminho Mínimo}

Alguns tipos de problemas possuem estruturas especiais em sua formulação que permitem simplificações ao algoritmo básico da programação linear (de NEUFVILLE e STAFFORD, 1971). Assim, o Problema do Transporte constitui uma das primeiras aplicações de programação linear a uma determinada situação bastante comum em planejamento e operação de sistemas de transporte (NOVAES, 1978). Esse problema foi proposto inicialmente por Hitchcock (HITCHCOCK, 1941), tendo sido discutido mais tarde por Koopmans (KOOPMANS, 1949).

Segundo Hillier e Lieberman (1988), o Problema do Transporte geral diz respeito (literal ou figurativamente) à distribuição de qualquer mercadoria de qualquer grupo de centros de oferta, chamados de fontes, para qualquer grupo de centros de recebimento, chamados de destinos, de tal modo que minimize os custos totais de distribuição.

Conhecendo as $m$ origens; os $n$ centros consumidores; as quantidades $a_{1}, a_{2}, \ldots, a_{n}$ disponíveis nas origens $m$; as demandas $b_{1}, b_{2}, \ldots, b_{n}$, em cada $n$ consumidor; e o custo unitário em cada rota entre a origem $i$ e o destino $j$, representado por $C_{i j}$, podemos representar o modelo matemático como:

$$
\begin{aligned}
& \operatorname{Min} \sum_{i=1}^{m} \sum_{j=1}^{n} C_{i j} x_{i j}, \quad \text { sujeito a } \sum_{i=1}^{\sum_{j=1}^{n} x_{i j} \leq a_{i}} \\
& \operatorname{com} i=1,2, \ldots, m \text {, } \\
& j=1,2, \ldots, n, \mathrm{e} \\
& x_{i j} \geq 0 \text { para qualquer } i \text { e } j \text {, onde } x_{i j} \text { representa a quantidade do produto que } \\
& \text { deve ir da origem } i \text { para o destino } j \text {. }
\end{aligned}
$$


A peculiaridade do problema do Transporte permite uma simplificação onde a soma das ofertas $a_{1}, a_{2}, \ldots, a_{m}$ seja igual à soma das demandas $b_{1}, b_{2}, \ldots, b_{n}$. Com isso, a mesma função objetivo inicial fica sujeita às seguintes restrições:

$$
\begin{aligned}
& \sum_{j=1}^{n} x_{i j}=a_{i} \\
& \sum_{i=1}^{m} x_{i j}=b_{j} \\
& \text { onde } i=1,2, \ldots, m ; \text { e } j=1,2, \ldots, n
\end{aligned}
$$

Um outro problema importante envolvendo fluxo em rede é o Problema do Caminho Mínimo. Para a resolução desse tipo problema, diversos autores descrevem técnicas e algoritmos de programação linear (FORD e FULKERSON, 1962; POTTS e OLIVER, 1972; RAVINDRAN et al., 1987; BAZARAA et al., 1990), como por exemplo: o método simplex, o algoritmo de Shimbel, de Murchland, de Hu, o out-ofkilter, e outros. No entanto, o intuito deste trabalho é apenas apresentar a formulação matemática básica a ser aplicada em qualquer uma das técnicas citadas.

Assim, suponha uma rede $G$ com $m$ nós, $n$ arcos, e um custo associado a cada arco $C_{i j}$ em $G$. Segundo Bazaraa et al. (1990), o problema do caminho mínimo é então: encontrar o menor caminho (ou custo) a partir do nó 1 ao nó $m$ em $G$. Isso quer dizer que o custo da rota é igual à soma dos custos dos arcos que a compõem, acrescidos eventualmente dos custos de transposição dos nós, que podem ser atrasos em interseções ou penalidades (POTTS e OLIVER, 1972). A formulação matemática para solução em programação linear é portanto:

$$
\operatorname{Min} \sum_{i=1}^{m} \sum_{j=1}^{m} C_{i j} x_{i j}, \quad \text { sujeito a: }\left\{\begin{array}{c}
\sum_{j=1}^{m} x_{i j}-\sum_{k=1}^{m} x_{k i}=1 \text { se } i=1 \\
\sum_{j=1}^{m} x_{i j}-\sum_{k=1}^{m} x_{k i}=0 \text { se } i \neq 1 \text { ou } m \\
\sum_{j=1}^{m} x_{i j}-\sum_{k=1}^{m} x_{k i}=-1 \text { se } i=m \\
\quad i, j=1,2, \ldots, m
\end{array}\right.
$$


onde as somatórias e as condições 0 - 1 são consideradas para os arcos existentes em $G$. A restrição $x_{i j}=0$ ou 1 indica se o arco faz parte ou não do caminho (matriz de incidência).

O Problema dos Transportes e do Caminho Mínimo são duas das mais utilizadas aplicações da pesquisa operacional em trabalhos científicos de modo geral. Embora essas sejam formulações que remontam ao início dos estudos em pesquisa operacional, muitos pesquisadores continuaram a pesquisá-los e utilizá-los em novas técnicas e ferramentas que vêm surgindo no decorrer dos anos. Isso dá a entender que, mesmo sendo matematicamente simples de serem solucionadas e compreendidas, essas técnicas são eficientes e capazes de resolver uma série de problemas relacionados ao cotidiano.

Dentre alguns dos muitos trabalhos que podem ser citados na aplicação do Problema dos Transportes estão: Tada e Ishii (1996); Marín e Pelegrín (1996); Sun et al. (1998); Sharma e Sharma (1998); Sun (2001). Cada um ao seu modo, destaca esse modelo aplicado a técnicas como branch-and-bound, lógica fuzzy, busca tabú, etc.

Já para o Problema do Caminho Mínimo podem-se citar os trabalhos de: Winston (1995); Bookbinder e Fox (1998); Kalsaas (1999); Davis Jr. (2000) e Teixeira e Cunha (2002), os quais aplicam essa técnica para planejar e avaliar operações de intermodalidade, roteamento de veículos, custos de transporte e escolha modal.

No entanto, percebe-se desses exemplos de aplicação, que há primordialmente uma preocupação em desenvolver as ferramentas utilizadas e testar suas capacidades. As conclusões geralmente fazem pouca menção à contribuição dessas pesquisas ao mercado de transportes, o que difere do cerne dessa pesquisa. Apesar disso, se expressa grande gratidão a esse tipo de pesquisa, as quais possibilitaram o desenvolvimento de novos programas e técnicas de ambientes cada vez mais familiares aos usuários em geral.

\subsection{Aplicações de Teorias de Fluxo em Rede nos SIGs}

Depois de feita as discussões sobre as bases teóricas relacionadas aos modelos de redes de transporte, é necessário que se faça a escolha da ferramenta de aplicação do modelo. Neste trabalho, uma preocupação análoga ao estudo de Miller et al. (1996) 
pode ser notada. A adoção de um programa computacional comercial, de inteface amigável para seus usuários, é algo interessante do ponto de vista do tempo economizado para a modelagem do problema. Embora existam solvers computacionais acompanhados de algumas linguagens ( $\mathrm{C}$ ou Fortran, por exemplo) que possibilitem uma maior flexibilidade ao modelo, é necessário que o usuário despenda, nesses casos, de um longo período para o desenvolvimento da formulação e do código fonte do programa, além da habilidade em modelagem de programação matemática que esse deve possuir. Como exemplo, podem-se citar os seguintes programas que se encaixam neste perfil: GAMS, MINOS, OSL e MPSIII (MILLER et al., 1996).

Utilizar um software de Sistema de Informação Geográfica, no caso o TransCAD, foi, portanto, uma forma de utilizar uma ferramenta difundida no meio de transportes, a qual possibilita uma interface amigável para o usuário, principalmente durante a modelagem, bem como para aqueles que farão uso apenas dos seus resultados gerados, por meio de mapas temáticos e tabelas dos bancos de dados. Além disso, essa é uma ferramenta que para o mercado de transportes e outros setores de planejamento, possibilita a utilização de uma gama de recursos em situações distintas, como será mostrado a seguir.

Por definição, o Sistema de Informação Geográfica é um sistema de gerenciamento de banco de dados computacional com função de capturar, armazenar, recuperar, analisar e visualizar informações espaciais (LEWIS, 1990; SIMONETT, 1993). Esse representa no mercado de ferramentas computacionais um meio poderoso para gerenciar e integrar eficientemente vários tipos de informações necessárias para o planejamento, desenvolvimento, análise, operação, manutenção e administração de sistemas de transporte. Destaca-se entre suas vantagens a facilidade de edição e representação gráfica, tratamento topológico, ferramentas para pesquisa operacional, análises estatísticas, etc.

Na Engenharia de Transportes os SIGs recebem a denominação de SIG-T e podem ter aplicações diversas. Neste sentido, Kahn e Armstrong (2001) fazem uma revisão bibliográfica do papel dos SIGs-T no aumento da flexibilidade e confiabilidade do gerenciamento e planejamento dos transportes urbanos. Especificamente como ferramenta de suporte ao planejamento urbano, Souza (2000) faz uso da aplicação de um SIG-T na análise e otimização do atendimento a locais de potencial risco de 
incêndio na cidade de São Carlos-SP. Lima (2003) utiliza um SIG-T com o propósito de fornecer suporte a problemas de decisão espacial na implantação e utilização de equipamentos coletivos públicos (escolas, postos de saúde, etc.) com o objetivo de reduzir os custos de transporte ao usuário.

Os SIGs também podem ser utilizados como ferramentas de um sistema de gerência de manutenção de vias, como aplicado por Viviani (1998), onde são armazenadas e manipuladas informações referentes a estradas rurais não pavimentadas. Com relação às rodovias pavimentadas, Lotti (2002) adota um SIG-T para investigar a relação dos acidentes acontecidos numa estrada às suas características físicas básicas (raio de curva horizontais e verticais, declividade e comprimento de rampas). Nessa aplicação é escolhido um SIG em virtude de sua capacidade de integração de diversas fontes de dados e apresentação gráfica de resultados. Amorim et al. (2001) descrevem os métodos utilizados para construir um Sistema de Apoio Rodoviário sobre uma plataforma SIG-T. Tal ferramenta possui um extenso banco de dados sobre as rodovias brasileiras, que em conjunto com os mapas gerados pelo SIG-T, têm o objetivo de auxiliar o planejamento de viagens e prover segurança aos usuários do transporte rodoviário.

Autores como Beghini (2002) e Tiago (2002) utilizam ferramentas de pesquisa operacional disponíveis em softwares de SIG-T para investigar a localização de pontos promissores de determinadas instalações (incinerados para resíduos de saúde e terminais intermodais respectivamente). O intuito neste caso é minimizar os custos de transporte dos pontos de demanda da rede aos pontos selecionados pelo programa. Kalsaas (1999) também lança mão de um SIG-T para obter a melhor localização de um terminal intermodal, porém seu objetivo principal é encontrar a melhor opção sustentável em seu cenário, aumentando a participação dos modos ferroviários e hidroviários em detrimento ao modo rodoviário. Outras ferramentas de pesquisa operacional num software de SIG-T também são aplicadas a problemas de minimização de custos, caminhos mínimos e roteirização em redes de transporte, como nos trabalhos de Collishonnn e Pilar (1999), Sarkis (2000), Davis Jr. (2000) e Rorato (2003).

Outros trabalhos têm objetivos específicos mais relacionados à criação de mapas temáticos sobre custos gerados em redes de transportes utilizando softwares de SIG-T. Horner e O'Kelly (2001), por exemplo, estudam a economia de escala gerada por 
terminais do tipo hub, localizados estrategicamente em algumas cidades americanas, usando um modelo não linear de custos de transportes. Southworth e Peterson (2000) constroem representações temáticas do movimento de cargas anuais por região geográfica, combinação de modos, tonelagem e tamanho da carga nos Estados Unidos. Já Beuthe et al. (2002) desenvolvem um modelo para comparar os custos externos (congestionamento, poluição, ruído, danos ao pavimento e acidentes) gerados pelo fluxo de cargas no transporte rodoviário, e o custo de operação no transporte multimodal, para esse mesmo fluxo de carga.

Dessa forma fica exemplificada a vasta aplicação dos Sistemas de Informação Geográfica na Engenharia de Transportes, bem como o seu potencial em auxiliar os profissionais da área na análise de problemas de forma mais rápida e confiável, inclusive nas atividades que envolvem fluxo em rede. 


\section{MODELOS DE CUSTOS E REDES DE TRANSPORTE}

A representação do fenômeno por um modelo matemático representativo requer a adoção de uma série de modelos que representem o valor esperado de custo de transporte entre um nó de origem e um nó de destino, passando eventualmente, por nós intermediários (terminais de transbordo) que também agregarão custos à operação de transporte.

Essa representação não é simples e depende da adoção de uma série de critérios, ou hipóteses, que restringem a acurácia dos valores finais do modelo para uma série de cenários que se quer investigar.

Se uma empresa possui uma frota rodoviária própria então um modelo de custo operacional pode representar bem o valor esperado do custo de transportar. Se, por outro lado, a estratégia adotada é a de contratar transporte com terceiros, então o frete médio pode representar o valor esperado do custo de transportar ao longo de um período (uma safra, por exemplo).

Quando existe variação sazonal considerável nos fretes e nos volumes transportados, o que é freqüente no transporte rodoviário de produtos agrícolas, então, avaliar o transporte por frota própria versus contratação de fretes pode ser um objetivo da investigação e requer uma modelagem mais detalhada dos fretes e volumes transportados em cada período. Portanto, comparar modelos de custos e fretes em cenários diversos é uma alternativa para sinalizar a melhor estratégia de transportes por uma determinada empresa e produto.

Essa avaliação também é válida no transporte intermodal rodo-ferroviário, pois os percursos da ponta necessários para abastecer os nós intermediários (terminais de transbordo) são efetuados pelo modo rodoviário, portanto, passíveis de uma opção entre frota própria ou terceirizada. No entanto, a operação ferroviária é totalmente terceirizada pelas concessionárias, daí a adoção de um modelo ferroviário estritamente baseado em fretes. Esses fretes, ao contrário do modo rodoviário, geralmente são constantes ao longo da safra, o que sugere uma estrutura de cálculo em sua formação diferente do modo rodoviário. 
Neste capítulo serão discutidos os modelos de custos e valores de fretes para a modelagem do sistema de transporte rodo-ferroviário de açúcar, e as limitações que eles impõem aos resultados numéricos do modelo.

\subsection{Custo Operacional Rodoviário}

Antes de tudo é necessário esclarecer o termo “custo operacional” rodoviário que será amplamente utilizado nesta dissertação. Faz-se necessário dizer que este se refere exclusivamente ao custo desembolsado pelo transportador responsável pela transferência do açúcar a granel das usinas ao porto, ou aos terminais intermodais rodoferroviários. Eventualmente a palavra “custo” poderá aparecer no texto ou nos apêndices desacompanhada das palavras “operacional” ou "percebido”, o que poderia causar alguma dúvida quanto ao seu conceito básico. No caso, a palavra custo poderia ter o sentido de custo total, o que se subentende que além dos custos operacionais, outros custos como o de construção da infra-estrutura, impactos ambientais e tempo, por exemplo, deveriam estar inclusos. O fato é que nessa dissertação apenas o custo percebido (ou desembolsado) pelo transportador será considerado.

Para a determinação dos custos operacionais rodoviários é utilizado um modelo construído pela Associação Nacional do Transporte de Cargas e Logística (NTC), atualizado e adaptado para as condições dessa pesquisa. Todos os dados de entrada do modelo, os quais foram executados em planilhas de cálculo no MS Excel, são do mês de junho do ano de 2004.

Uma suposição básica importante neste modelo é que o custo por quilômetro calculado é igual para todas as usinas, independente das localizações geográficas variadas. Assim, o que faz com que o custo absoluto se diferencie entre as usinas são as respectivas distâncias até o porto (ou terminais) e os valores dos pedágios cobrados nos arcos.

Esses valores de pedágios foram levantados nos sites da Associação Brasileira das Concessionárias Rodoviárias (ABCR, 2004) e da Agência Reguladora de Transportes do Estado de São Paulo (ARTESP, 2004). No entanto, a sua inclusão na modelagem acontece apenas na etapa de simulação (capitulo 5), uma vez que essas são penalidades impostas à rede de transportes na simulação. 
O objetivo específico da modelagem dos custos rodoviários é, portanto, fornecer um valor de custo operacional por quilômetro $(\mathrm{R} \$ / \mathrm{km})$ para cada alternativa de CVC, o qual será utilizado como dado de entrada na etapa de simulação (capítulo 5). A partir desta informação, poder-se-á estimar o custo absoluto para um ciclo de viagem, que indiretamente leva em consideração a capacidade de cada CVC, pois, de acordo com a lotação de uma combinação, mais ou menos viagens deverão ser feitas para suprir a demanda por transporte das usinas em questão, o que pode ser subentendido como um custo por tonelada quilômetro.

A composição dos custos operacionais nesse modelo divide-se em duas parcelas:

- Custos diretos das operações dos veículos;

- Despesas indiretas administrativas da operação.

\subsubsection{Custos Diretos das Operações dos Veículos}

Os custos diretos, responsáveis pela maior parte do custo rodoviário total, correspondem às despesas do transporte de cargas entre dois terminais, e são divididos em duas partes: custos fixos e variáveis (Kawamoto, 1999; NTC, 2001).

No entanto, antes de apresentar as descrições desses custos, os conceitos de produtividade e taxa de utilização das combinações serão apresentados, pois esses influenciam diretamente na formação dos custos diretos.

\section{Quilometragem Percorrida Mensalmente (QPM)}

A quilometragem percorrida mensalmente é a variável que determina a produtividade da combinação. Essa variável tem efeito direto sobre os custos fixos. pois um aumento na produtividade significa um decréscimo relativo nos custos, pois há uma divisão desses custos por uma utilização maior em um intervalo fixo de tempo.

Dependendo do comprimento do arco percorrido existe uma variação da produtividade mensal, por exemplo, em função do tempo perdido nas operações de embarque e desembarque da carga nos terminais.

As produtividades adotadas para esse trabalho são de 15.000 quilômetros para as combinações que fazem o ciclo usina-terminal -usina, e de 20.000 quilômetros para as 
que fazem o ciclo usina-porto-usina. A forma como essas produtividade foram estimadas neste trabalho encontram-se no Apêndice A.

\section{Taxa de Utilização de uma CVC}

A taxa de utilização de uma CVC equivale à lotação que é efetivamente ocupada durante um ciclo. Essa informação diz respeito à incidência do frete de retorno. Na modelagem inicial do problema de transporte de açúcar para o Porto, não há consideração de carga de retorno, ou seja, o veículo tem sua lotação ocupada apenas no percurso de ida e em sua volta encontra-se descarregado. No entanto, na análise de sensibilidade do potencial de competitividade do transporte rodoviário, que será tratada no capítulo de resultados (capítulo 6), haverá simulações de casos com incidência de fretes de retorno da ordem de 20, 35 e 50\%. Como ilustração, isso significa dizer que, no primeiro caso, uma combinação do tipo bitrem de 7 eixos (3S2B2), com oferta de transporte de 37 toneladas em um sentido (ou 74 toneladas no ciclo), voltará com frete de retorno do porto em $20 \%$ dos seus ciclos. Pressupõe-se então que a receita gerada pelo frete de retorno abata uma parte proporcional dos custos totais de transporte, ou seja, que o frete unitário de retorno gera uma receita igual ao custo operacional unitário.

Um exemplo de aplicação da taxa de utilização para ilustrar como o seu cálculo será efetuado encontra-se no Apêndice B.

\subsubsection{Custo Fixo Mensal}

É o custo que decorre independente da movimentação do veículo. Nesse modelo o custo fixo mensal é composto pelas seguintes parcelas:

- Remuneração de capital da composição (RCC);

- Salário do motorista (SM);

- Salário de oficina (SO);

- Depreciação da unidade tratora (DT);

- Depreciação do implemento (DI);

- Licenciamento $(L I)$;

- Seguro de casco da unidade tratora (SCT); 
- Seguro de casco do implemento (SI);

- Seguro de responsabilidade civil facultativo (SRCF);

- Seguro da carga (açúcar a granel) (SC);

- Sistema de monitoramento por satélite (SMS);

- Autorização Especial de Trânsito (AET).

O custo fixo $(C F)$ mensal resulta por fim da soma das parcelas mencionadas:

$C F=R C C+S M+S O+D T+D I+L I+S C T+S C I+S C+S R C F+S M S+A E T$

O Apêndice C apresenta a descrição detalhada do modelo de custos fixos, e o Apêndice E a sua aplicação em planilha eletrônica para o cálculo dos custos operacionais rodoviários, em situações operacionais de 15.000 e 20.000 quilômetros mensais.

\subsubsection{Custo Variável por Quilômetro}

É o custo decorrente da movimentação do veículo, variável em função da quilometragem percorrida mensalmente $(Q P M)$. Nesse modelo, o custo variável por quilômetro é composto pelas seguintes parcelas:

- Peças, acessórios e material de manutenção (PM);

- Combustível (CO);

- Lubrificantes $(L U)$;

- Lavagem e lubrificação externa (LLE);

- Pneus e recauchutagem $(P R)$.

O custo variável total $(C V)$ é obtido pela soma das cinco parcelas mencionadas:

$C V=P M+C O+L U+L L E+P R$

O Apêndice D apresenta a descrição detalhada do modelo de custos variáveis, e o Apêndice E a sua aplicação em planilha eletrônica para o cálculo dos custos 
operacionais rodoviários, em situações operacionais de 15.000 e 20.000 quilômetros mensais.

\subsubsection{Despesas Indiretas Administrativas da Operação}

As despesas indiretas são aquelas que não estão relacionadas diretamente com a operação do veículo (Kawamoto, 1999; NTC, 2001). Essas, compostas com as despesas de transferência, formam o custo operacional da combinação. As parcelas das despesas indiretas são:

- Salários e encargos sociais do pessoal envolvido com a operação dos veículos (pessoal administrativo, vendas, diretoria, etc.);

- Despesas necessárias para o funcionamento da empresa: aluguel, impostos, material de escritório, comunicações, depreciação de máquinas e equipamentos, etc.

Como a estrutura deste modelo é aplicada a um universo de oito usinas, cujas informações individuais seriam de difícil estimativa, preferiu-se adotar uma relação entre custo direto e indireto da ordem de $88 \%$ para os diretos e $12 \%$ para os indiretos, os quais retratam satisfatoriamente o cenário do mercado de transportes, como ilustrado por Neuto Gonçalves dos Reis, em e-mail e anexos enviados para o autor presentes no Apêndice F.

Assim, o equacionamento das despesas indiretas (DIn) fica:

$$
D I n=\frac{(C F+(C V \times Q P M)) \times i d i}{i d d}
$$

onde,

$C F$ : custo fixo (R\$);

CV: custo variável $(\mathrm{R} \$ / \mathrm{km})$;

QPM: quilometragem percorrida mensalmente $(\mathrm{km})$;

idi: 0,12 (índice de despesas indiretas);

idd: 0,88 (índice de despesas diretas). 
O cálculo em planilha eletrônica dos custos indiretos é apresentado conjuntamente com os outros custos no Apêndice E.

\subsubsection{Cálculo Final dos Custos Rodoviários Percebidos}

O custo operacional rodoviário por quilômetro calculado ao final deste modelo resulta por fim da seguinte equação:

$C R o d=\frac{(C F+\operatorname{Din})}{Q P M}+C V$

onde,

CRod: custo rodoviário percebido por quilômetro $(\mathrm{R} \$ / \mathrm{km})$;

CF: custo fixo (R\$);

$C V$ : custo variável por quilômetro $(\mathrm{R} \$ / \mathrm{km})$;

Din: despesas indiretas administrativas (R\$);

QPM: quilometragem percorrida mensalmente $(\mathrm{km})$.

Os resumos dos custos rodoviários percebidos, para as produtividades de 15.000 e 20.000 quilômetros, são apresentados no Apêndice G.

\subsection{Frete do Transporte Rodoviário}

Como preconizado anteriormente, para efeito de comparação entre a operação de combinações próprias ou terceirizadas, será utilizado um modelo com os fretes rodoviários de açúcar a granel cobrados entre um conjunto de empresas e o porto de Santos, bem como entre as usinas e os terminais intermodais.

O frete por definição representa os preços negociados, que pode variar em cada ocasião, e tem como objetivo cobrir os custos e gerar uma margem de lucro conveniente para o prestador do serviço. O preço do frete pode ser estipulado de acordo com o objetivo do prestador do serviço de transporte, podendo este ser em função do custo médio, marginal ou pelo valor do serviço (KAWAMOTO, 1999). Deve-se ressaltar também que, teoricamente, na contratação do frete rodoviário, o prestador de serviço 
também está embutindo em seus custos as despesas relativas à volta da combinação vazia.

Uma hipótese adotada pelo modelo de fretes rodoviários é que, especificamente para as combinações que perfazem a ponta entre as usinas e os terminais de transbordo, o frete cobrado será constante durante a safra. Isso porque, avaliando os dados inicias de fretes fornecidos pelas usinas, percebe-se pouca (ou quase nenhuma) variação em seus valores, tanto nos percursos entre as usinas e os terminais servidos pela FCA (Ribeirão Preto e São Joaquim da Barra), quanto nos da Brasil Ferrovias (Engenheiro Schmidt). Embora as operações tenham durações diferentes (como será esclarecido mais adiante), os negociadores ainda conseguem, para os trajetos das pontas, fechar contratos com valores mais constantes. O Apêndice $\mathrm{H}$ apresenta os valores dos fretes cobrados entre as usinas e os terminais intermodais utilizados neste trabalho.

Para as demais combinações que perfazem o ciclo rodoviário completo, o valor do frete é variável ao longo da safra. O Apêndice I apresenta os valores médios dos fretes mensais cobrados de cada usina do grupo objeto do estudo de caso no trajeto até o porto de Santos, os quais serão utilizados na modelagem. Na composição da tabela de fretes, as usinas 1, 2, 3, 4 e 7 têm seus valores negociados pela trading responsável pela comercialização do grupo; já as usinas 5, 6 e 8 têm autonomia para negociar seus próprios valores de fretes.

Percebe-se pela análise dos valores da safra 2004/2005 (Apêndice I) que o frete nem sempre segue um padrão de acréscimo ou decréscimo em relação à variação da produção, ou da distância. Isso leva a crer que a variação do frete está mais relacionada ao poder de negociação de ambas as partes (contratante e contratado) do que a um modelo racional de remuneração dos custos totais. Outros fatores também podem servir de diferencial da composição dos valores de fretes, como: a concorrência de outros produtos para serem transportados, novas transportadoras no mercado, tecnologia de transporte e estrutura física das empresas.

\subsection{Frete do Transporte Ferroviário}

Em virtude da dificuldade para se encontrar informações para a montagem de um modelo de custos ferroviários, adotou-se para esse modelo os valores de fretes cobrados 
pelas concessionárias para o transporte de açúcar a partir de determinados terminais intermodais, os quais são utilizados atualmente pelo conglomerado de usinas que forneceram os dados para essa investigação. Tal adoção já pode ser verificada em trabalhos como os de Takahashi et al. (2001), Tiago (2002), Souza et al. (2002) e Castro (2002).

A operação ferroviária envolvida nesta pesquisa apresenta duas situações distintas: a primeira envolve os terminais de Ribeirão Preto e São Joaquim da Barra, conectados à malha da Ferrovia Centro Atlântica (FCA). Nestes terminais, a trading responsável pela negociação com a concessionária ferroviária estabeleceu um contrato de embarque de açúcar durante toda a safra (abril a janeiro). Isso é possível porque esses terminais são exclusivos para embarque de açúcar, e não há risco de contaminação do produto em armazéns e nas operações de transbordo.

Pelo contrato firmado entre a trading e a FCA, o serviço de transporte ferroviário está limitado em 450.000 toneladas de açúcar, de abril a janeiro, divididos igualmente entre os dois terminais. Embora este seja o limite estabelecido (e utilizado como restrição neste trabalho), segundo a trading, apenas metade deste total é embarcado durante a safra, devido à falta de vagões e locomotivas de tração, manutenção das vias, dentre outros fatores. Assim, na prática, uma programação semanal para embarque de açúcar é feita de acordo com as disponibilidades operacionais da FCA.

A segunda envolve o terminal de Engenheiro Schmidt conectado à malha da Brasil Ferrovias. Nesse terminal a operação só é possível entre os meses de setembro e janeiro, pois nos meses anteriores, há utilização dos armazéns com outros produtos. Além disso, por ser de administração pública (CEAGESP), o armazém do terminal tem o caráter de servir a pequenos produtores da região, não podendo desta forma dar exclusividade aos produtores de açúcar. Em virtude dessa falta de exclusividade, apenas 10.000 toneladas de açúcar podem ser embarcadas por mês nesse período, sendo que em alguns casos, o transbordo é direto dos caminhões para os vagões, pois não há possibilidade de armazenagem e para se evitar contaminações com os demais produtos dos armazéns.

O frete ferroviário cobrado pelas concessionárias contempla duas parcelas diferentes: o transbordo da carga do modo rodoviário para o modo ferroviário no terminal intermodal; e o transporte entre o terminal intermodal e o porto de Santos, 
também denominado de frete operacional. A soma dessas duas parcelas corresponde à tarifa total cobrada para o transporte de açúcar a granel. É importante ressaltar que o transbordo para o modo marítimo hidroviário (também chamado de elevação) no Porto de Santos não foi considerado em nenhum dos modelos de custos elaborados.

Algumas suposições iniciais foram impostas ao modelo de custos ferroviários:

- Ao contrário do que acontece no modo rodoviário, o frete negociado para o modo ferroviário será considerado constante durante os períodos de operação (abril a janeiro - FCA, e setembro a janeiro - Brasil Ferrovias), como geralmente acontece na prática;

- Será considerado um limite de capacidade de embarque de açúcar por mês em cada terminal intermodal, em virtude da indisponibilidade operacional dos terminais e/ou de vagões e veículos de tração, alocados em sua maioria no transporte de outros produtos;

- Inicialmente, toda a demanda por transporte de açúcar será alocada ao modo ferroviário até que o limite de capacidade de cada terminal seja alcançado. A partir daí, todo o restante da demanda será alocada ao modo rodoviário porta-aporta, o qual é chamado de porta-a-porta complementar.

\subsubsection{Custo de Transbordo}

O custo do transbordo no transporte ferroviário é relativo às despesas de transferência da carga a granel do modo rodoviário para o modo ferroviário. Num cenário hipotético, esse seria o custo atribuído a um nó intermediário entre os pontos de origem e destino, aonde acontece a mudança de modos.

O custo de transbordo está associado à operação da ferrovia, e portanto, tem sua variação em função da quantidade transferida entre modos (em toneladas). Por isso, é comum que se adicione diretamente os dois custos (transbordo e transporte ferroviário).

Nesse modelo, assume-se que os terminais de transbordo selecionados para a transferência entre modos possui infra-estrutura física e tecnológica para operar as CVCs investigadas por essa pesquisa. Tal fato é relevante, pois, itens como geometria das vias de acesso, pisos dos estacionamentos e pátios, balanças e tombadores, por 
exemplo, são restrições importantes na operação das CVCs de 7 e 9 eixos, ainda pouco convencionais no mercado de açúcar a granel.

Além desses fatores existe o fato, já discutido anteriormente, de concorrência de produtos em alguns terminais, impedindo o escoamento do açúcar durante um período da safra.

Dessa forma, as informações relativas ao modelo de custos ferroviários operacionais e de transbordo coletados no mercado são as apresentadas na Tabela 4.3. Vale ressaltar que esses serão os valores utilizados para o cálculo dos custos no transporte intermodal do modelo.

Nota-se que no modelo de custos ferroviários o valor cobrado ao embarcador depende da quantidade embarcada em toneladas. Essa quantidade embarcada será definida em função da produção mensal de cada usina durante a safra, de suas localizações em relação aos terminais de transbordo, e dos limites de capacidade mensal de cada terminal, uma vez que essas serão as variáveis utilizadas pelo programa que fará a alocação das demandas de transporte de açúcar por terminal.

Tabela 4.3: Tarifas de frete cobradas no transporte ferroviário de açúcar a granel

\begin{tabular}{lrrrrrr}
\hline Terminal & $\begin{array}{c}\text { Distância } \\
(\mathrm{km})\end{array}$ & Operação & $\begin{array}{r}\text { Restrição } \\
\text { (ton/mês) }\end{array}$ & $\begin{array}{r}\text { Transbordo } \\
(\mathrm{R} \$ / \text { ton })\end{array}$ & $\begin{array}{r}\text { Frete Op. } \\
(\mathrm{R} \$ / \text { ton })\end{array}$ & $\begin{array}{c}\text { Frete Total } \\
(\mathrm{R} \$)\end{array}$ \\
\hline S.J. Barra & 623,0 & Abr - Jan & 22.500 & 4,50 & 38,51 & 43,01 \\
\hline Rib. Preto & 550,0 & Abr - Jan & 22.500 & 3,80 & 35,42 & 39,22 \\
\hline $\begin{array}{l}\text { Eng. } \\
\text { Schmidt }\end{array}$ & 645,0 & Set - Jan & 10.000 & 4,38 & 40,70 & 45,08 \\
\hline
\end{tabular}

Fonte: Crystalsev Comércio e Representação Ltda.

Percebe-se também da Tabela 4.3 que há proporção entre o frete total cobrado e a distância ao porto entre todas as opções apresentadas. Segundo Kawamoto (1999), isso acontece devido ao objetivo que os transportadores ferroviários têm na formação do frete. Geralmente, como também acontece nos modos aéreos e hidroviários, essa tarifação é estabelecida em função do valor de serviço, ou seja, ignoram-se os custos e cobra-se o equivalente ao serviço prestado, ou um valor que o usuário pode pagar. 
Nesse caso, a tarifa tem como limite superior o valor de se obter o serviço de uma fonte alternativa (transporte rodoviário), daí a razão dos fretes no modo ferroviário serem ligeiramente mais baixos do que os fretes do principal modo concorrente.

Para que esse esquema de tarifação tenha sucesso é necessário que ocorram as seguintes situações:

- Deve haver um certo grau de monopólio;

- Deve haver diferenciação entre usuários;

- Deve haver mercadorias cujas elasticidades em relação ao preço de transporte sejam diferentes.

Relacionando-se essas situações ao transporte de cargas no modo ferroviário, percebe-se que este é um exemplo típico de tarifação pelo valor do serviço.

Como se quer avaliar também uma situação hipotética em que não existem restrições de capacidade nos terminais de transbordo, tração e vagões, ocorre um problema na avaliação da tarifa ferroviária nessa condição de oferta do serviço. Adotarse-á, portanto, a hipótese de que a tarifa permanece inalterada durante toda a safra.

\subsubsection{Composição do Custo Total Rodo-Ferroviário}

Além das tarifas de fretes cobrados na operação do transporte e no transbordo da carga no modo ferroviário, deve-se adicionar aos custos ferroviários, os custos rodoviários relativos aos ciclos usina-terminal-usina, como já apresentados. Para critério de comparação, essa ponta rodoviária também será avaliada para o caso da contratação do transporte com terceiros.

No entanto, como o transporte ferroviário é capacitado nesse modelo, deve-se considerar também o custo adicional ocasionado pelo transporte da carga excedente não transportado pelo modo ferroviário (custo rodoviário porta-a-porta complementar). Assim como nas pontas, os custos dessa operação também serão avaliados para o transporte terceirizado.

Dessa forma, o custo total intermodal fica sendo então:

$$
C T_{R F}=\left(C F e r+C R_{\text {ponta }}\right)+C R_{\text {comp }}
$$


onde,

$C T_{R F}:$ custo total rodo-ferroviário (R\$);

CFer: custo ferroviário de transporte (R\$);

$C R_{\text {ponta: }}$ : custo rodoviário entre as usinas e os terminais intermodais (R\$);

$C R_{\text {comp: }}$ custo rodoviário porta-a-porta complementar (R\$).

\subsection{Modelo de Rede de Transportes}

O modelo de rede de transportes utilizado nesta pesquisa foi elaborado com o SIG TransCAD, versão 3.6. O objetivo específico dessa rede é representar a malha rodoviária e ferroviária do Estado de São Paulo, as usinas, terminais e cidades envolvidas na investigação, além de agregar às suas bases de dados informações relevantes para a etapa de simulação.

A base geográfica digital das rodovias de São Paulo foi obtida junto ao ex-aluno do Departamento de Transportes da EESC-USP, engenheiro Rafael José Rorato (RORATO, 2003), o qual baseou-se em informações do Instituto Brasileiro de Geografia e Estatística (IBGE), do Instituto Nacional de Pesquisas Espaciais (INPE), e do Programa de Engenharia de Transportes da Universidade Federal do Rio de Janeiro (PET-COPPE).

Já a base geográfica ferroviária foi obtida junto à empresa Brasil Ferrovias, por intermédio do engenheiro João Artur. No entanto, essa última base foi elaborada pela Fundação Seade - Sistema Estadual de Análise de Dados, e contempla dados históricos entre os períodos de 1983 a 1996, disponíveis para o SIG MapInfo. Embora possa parecer uma base desatualizada, pode-se afirmar que desde esse período praticamente nenhuma alteração ocorreu na malha ferroviária brasileira, e comparado a outras bases disponíveis para utilização, essa apresenta uma riqueza maior de detalhes quanto ao traçado das vias e localização de terminais.

No entanto, mesmo tendo-se trabalhado na atualização e adaptação das bases geográficas ferroviárias e rodo-ferroviária conjugadas, optou-se no decorrer da pesquisa a não utilizá-las na etapa posterior de simulação, onde o TransCAD deveria calcular o 
custo de uma viagem intermodal completa de uma usina ao porto. Isso se deu pela incompatibilidade das capacidades de carga dos veículos utilizados - no caso, caminhões com lotações entre 27 e 45 toneladas, e composições ferroviárias que variam suas lotações em função do número de vagões combinados - e das unidades de custo rodoviário $(\mathrm{R} \$ / \mathrm{km})$ e frete ferroviário (R\$/ton). Por esse motivo, optou-se por calcular os custos nos trechos rodoviários, através da simulação dos custos das viagens utilizando o TransCAD, e nos trechos ferroviários, através de planilhas eletrônica do MS Excel.

O intuito do autor é que essa base geográfica rodo-ferroviária elaborada seja disponibilizada para futuras pesquisas, onde o custo econômico por quilômetro do modo ferroviário possa ser mensurado, e, dessa forma, possa-se dar maior utilidade ao modelo sobre uma plataforma SIG.

Devido a esses motivos apresentados, apenas os procedimentos relativos à rede de transporte rodoviário serão aqui discutidos.

\subsubsection{Procedimento de Elaboração da Rede de Transportes Rodoviário}

Para a elaboração da rede rodoviária digital do Estado de São Paulo num Sistema de Informação Geográfica, adequada ao cenário proposto nesta pesquisa, foi necessário mesclar informações de diferentes origens. Os comandos dos procedimentos apresentados a seguir são encontrados em Caliper (1996a), Caliper (1996b), Silva e Waerden (1997) e Silva (2003), sendo que:

a.) da base geográfica de Rorato (2003) selecionou-se:

- Um arquivo de área referente aos limites territoriais do Estado de São Paulo;

- Um arquivo de pontos referente aos municípios do Estado de São Paulo;

- Um arquivo de pontos referentes às praças de pedágios do Estado de São Paulo;

- Um arquivo de linhas referente às rodovias em utilização do Estado de São Paulo. 
b.) da base geográfica do SEADE selecionou-se:

- Um arquivo de pontos referentes às estações e terminais ferroviários do Estado de São Paulo;

- Um arquivo de pontos referente ao Porto de Santos.

c.) dos dados fornecidos pelas usinas e coletados em campo com um GPS de navegação, inseriu-se:

- Um arquivo de pontos referente às usinas analisadas no estudo de caso.

Em seguida foram necessárias algumas adequações na base de dados de cada arquivo geográfico para que essas se adaptassem à realidade do cenário avaliado. Assim, foi necessário:

a.) no arquivo de pontos referentes aos municípios de São Paulo:

- Selecionar algumas cidades importantes do Estado somente como referências na rede.

b.) no arquivo de pontos referentes aos pedágios:

- Inserir novas praças do Estado de São Paulo, bem como outras que não estavam presentes no trabalho original;

- Atualizar o sentido de cobrança de algumas praças;

- Atualizar as tarifas nas praças do Estado de São Paulo.

c.) no arquivo de linhas da rede rodoviária:

- Excluir os campos que continham informações de tempo, velocidade e custos que se referiam exclusivamente ao trabalho original;

- Inserir vias de acesso conectando as usinas, terminais e o Porto à rede rodoviária do Estado de São Paulo;

- Inserir campos referentes aos custos absolutos para cada tipo de combinação de veículo; 
- Preencher os campos de custos de cada combinação de veículo multiplicando os comprimentos dos arcos pelos custos por quilômetro (calculados no modelo de custos rodoviários).

d.) no arquivo de pontos referentes aos terminais ferroviários:

- Selecionar somente os terminais que foram escolhidos para a pesquisa;

- Inserir um campo denominado Capacidade, contendo as capacidades de processamento mensal de carga em cada terminal.

e.) no arquivo de pontos referentes às usinas:

- Inserir um campo denominado Demanda, a ser preenchido com a demanda mensal por transportes de cada usina durante a etapa de simulação.

Terminadas as etapas de adaptação dos arquivos geográficos gerou-se um mapa digital da rede rodoviária do Estado de São Paulo, o qual é composto pela sobreposição dos layers dos arquivos geográficos, como mostrado na Figura 4.1. A partir do arquivo geográfico de linhas das rodovias foi gerada a rede rodoviária propriamente dita. Na criação da rede definiu-se que as distâncias devem ser lidas a partir do campo Length, os custos nos campos GRANEL(R\$), BASCULANTE(R\$), BITREM7(R\$) e BITREM9(R\$), e que seria permitido a essa rede a inclusão de penalidades (pedágios). Essas informações serão utilizadas na etapa de simulação. A Figura 4.2 mostra o banco de dados do arquivo de linhas referente às rodovias com os campos mencionados acima.

Para testar a integridade da rede elaborada, utilizou-se um método expedito para verificação da consistência de redes para uso em SIGs, formulado por Raia Jr. e Silva (1998). Esse método é uma aplicação do conceito de acessibilidade proposto por Allen et al. (1993), os quais a definem como a medida de esforço para superar a separação espacial entre dois pontos dentro de uma área (Raia Jr. e Silva, 1998). 


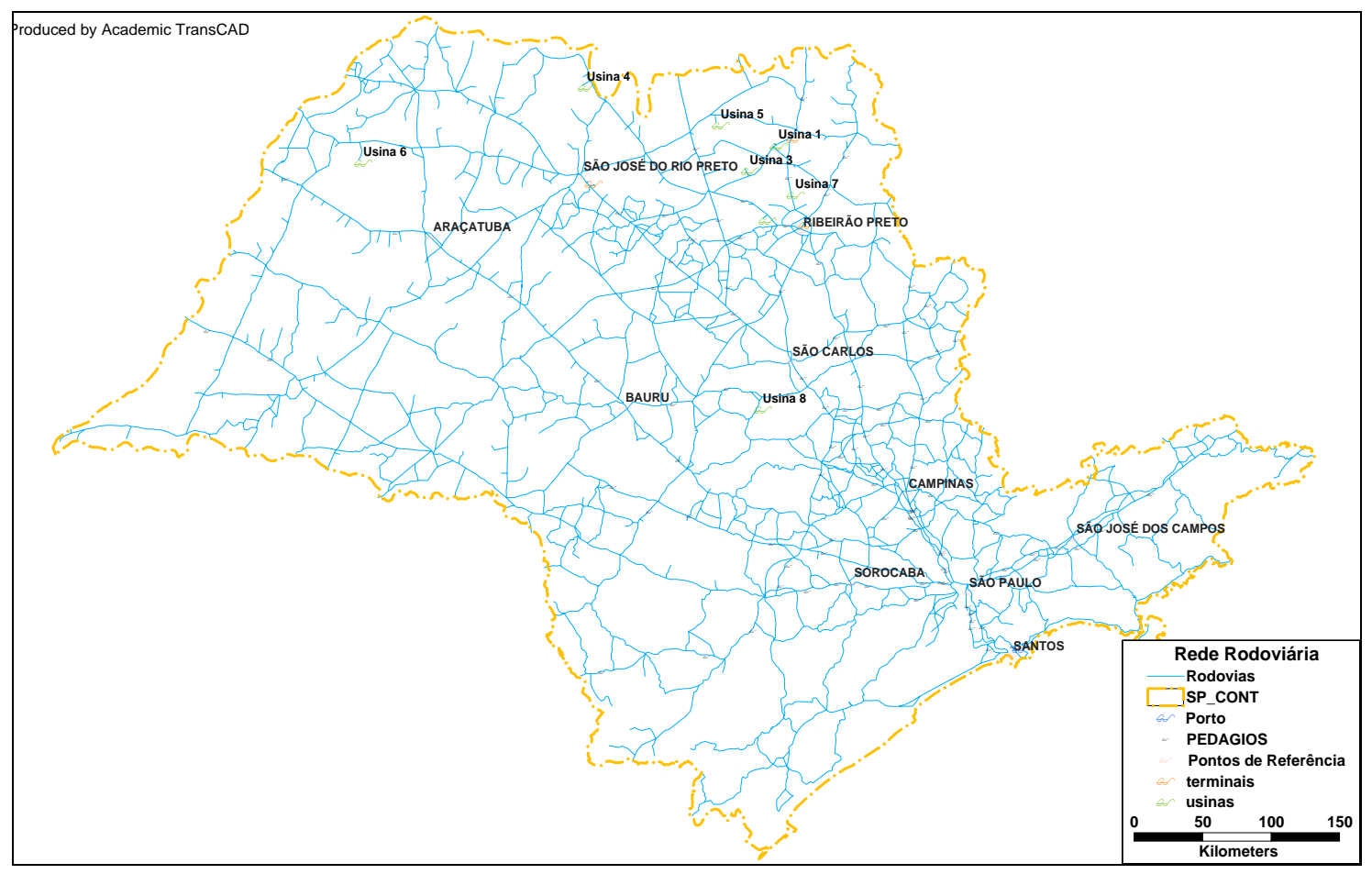

Figura 4.1: Mapa rodoviário do Estado de São Paulo.

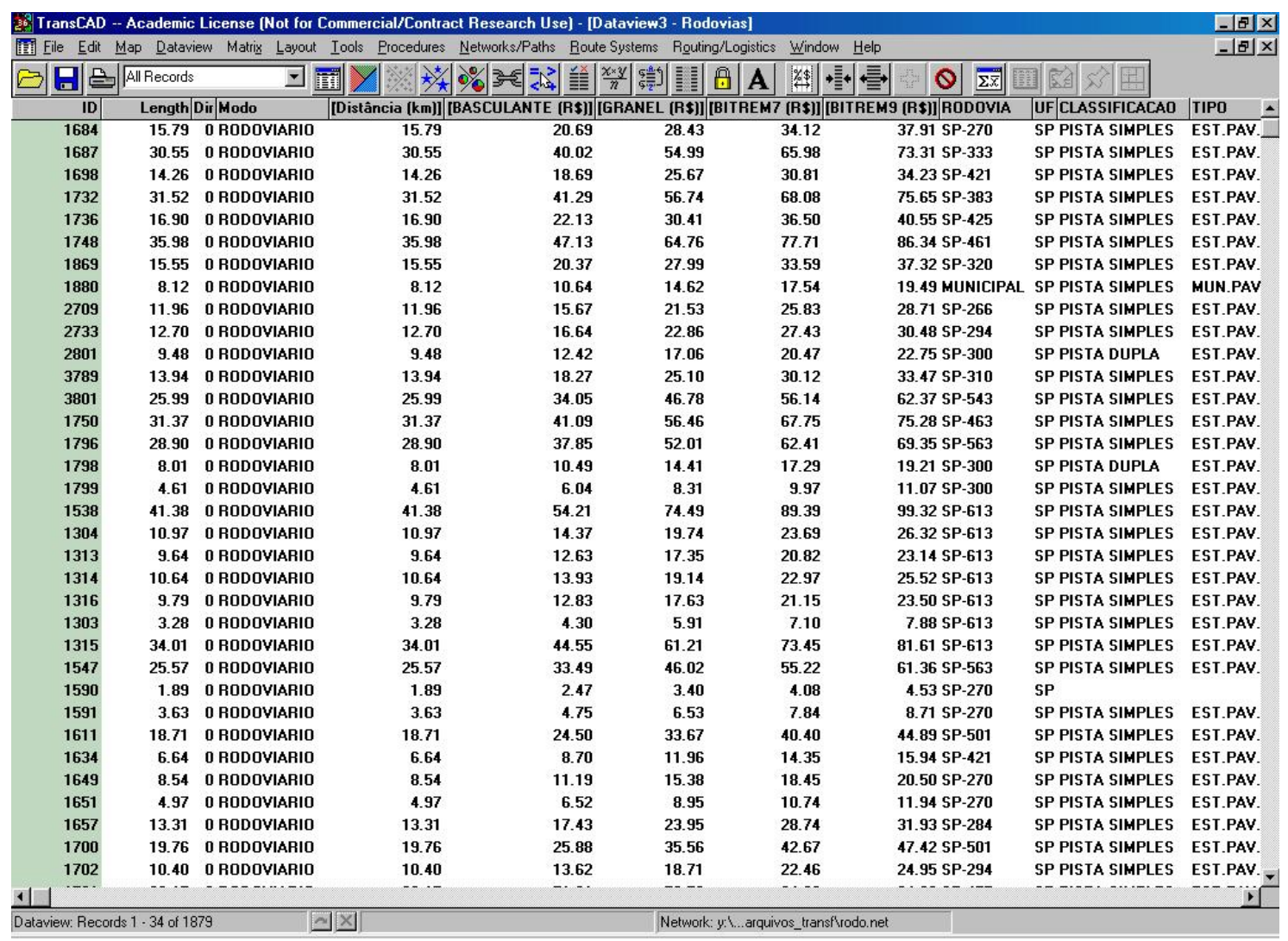

Figura 4.2: Banco de dados do arquivo de linhas referente às rodovias.

Seguindo o método proposto por Raia Jr. e Silva (1998) elaborou-se um mapa temático representando a acessibilidade de cada nó, como mostrado na Figura 4.3. A 
medida de acessibilidade de Allen et al. (1993) leva em consideração apenas os menores caminhos entre os pontos da rede, logo, os pontos nas regiões mais densas do Estado como nas proximidades das cidades de São Paulo, Campinas, Ribeirão Preto, São José do Rio Preto e Bauru - apresentam menores valores absolutos, e por conseqüência, maiores níveis de acessibilidade, pois os nós estão mais próximos entre si (pontos mais escuros do mapa). À medida que se afastam em direção às regiões mais periféricas, os nós apresentam valores absolutos maiores, ou seja, níveis menores de acessibilidade (pontos mais claros). Portanto, uma transição gradativa da coloração dos pontos das regiões mais densas para as regiões periféricas significa dizer que a rede não apresenta falha. Caso houvesse distorção nessa transição, algum ponto numa região periférica apresentaria alta acessibilidade. Isto sugere que haveriam nós desconectados na rede, que por apresentarem distâncias médias curtas entre si, esses nós teriam alta acessibilidade. Nesse caso, haveria necessidade de se reparar as conexões e refazer o teste de acessibilidade.

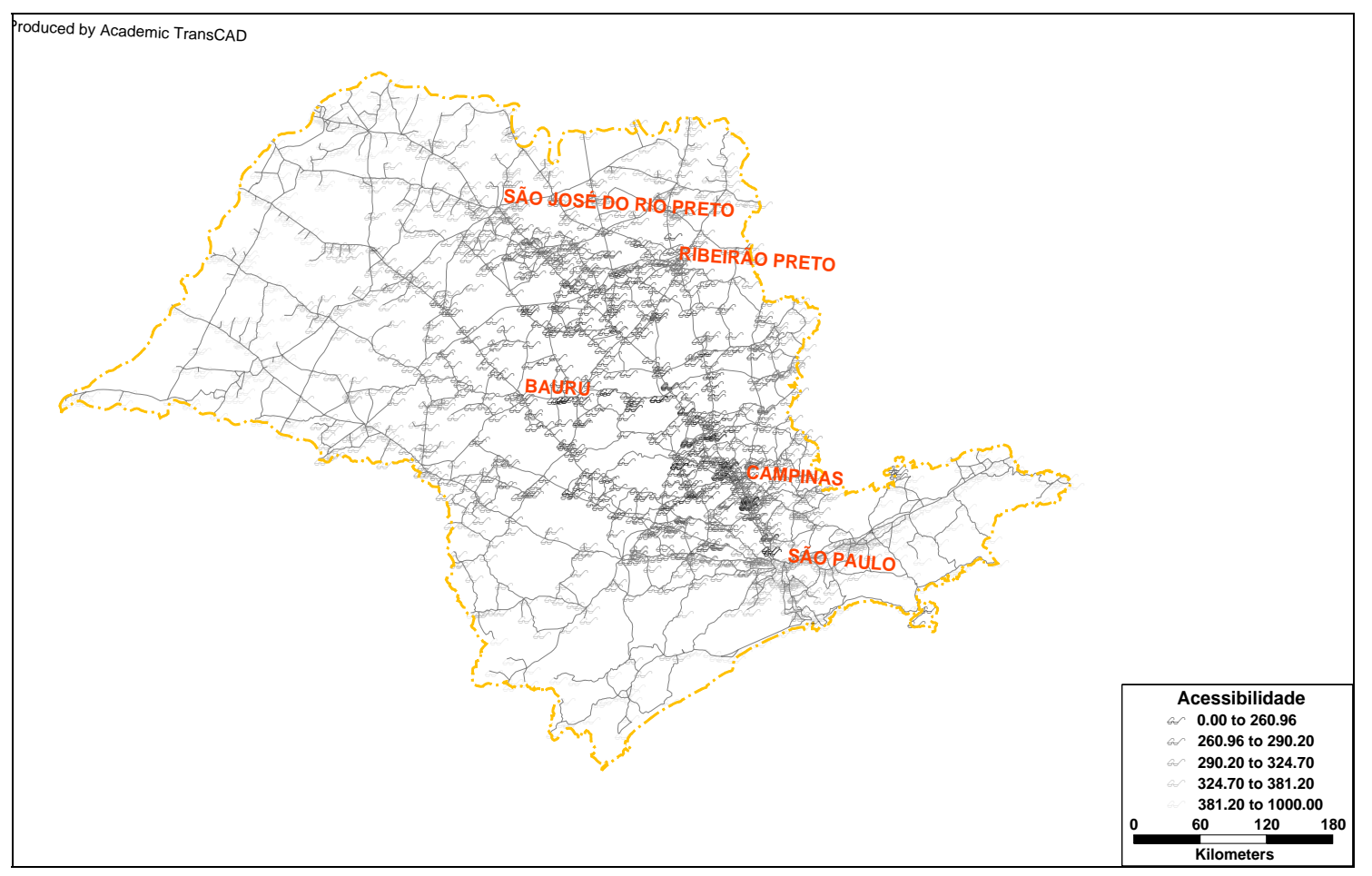

Figura 4.3: Mapa de acessibilidade da rede rodoviária do Estado de São Paulo.

Por uma análise visual da Figura 4.3 apresentada, constata-se que a rede não apresenta falhas de conexão, pois seus níveis de acessibilidade sofrem mudanças gradativas da região central para a periférica, sem a presença de pontos escuros em regiões de baixa acessibilidade. 


\section{ESTUDO DE CASO}

Neste capítulo serão mostradas as aplicações dos modelos até aqui apresentados, através de simulações de fluxos de transporte de açúcar, envolvendo usinas do Estado de São Paulo e o Porto de Santos.

A divisão em cenários se deve em função das alternativas entre modos de transporte (rodoviário e ferroviário), das tecnologias presentes no modo rodoviário (graneleiros de 5 eixos, basculantes de 6 eixos e bitrens de 7 e 9 eixos), da opção entre utilizar frota própria ou terceirizada, e da limitação de capacidade no transporte ferroviário.

Desta forma, o objetivo específico que se busca aqui, é estimar os custos do transporte de açúcar em valores absolutos, em diferentes situações (ou cenários), mensalmente durante uma safra. Essas informações serão então, o ponto de partida para o capítulo seguinte de análise de resultados.

Os dados apresentados a seguir são reais para a safra que se iniciou em abril de 2004 e perdurou até janeiro de 2005. Esses dados foram cedidos em parte por uma trading que comercializa o açúcar tipo VHP de 8 usinas que participam de seu conglomerado. Em alguns momentos, as próprias usinas envolvidas forneceram dados para alimentar os modelos.

Em termos espaciais, essas usinas encontram-se espalhadas heterogeneamente no Estado de São Paulo, predominantemente nas regiões de Ribeirão Preto e São José do Rio Preto, que a pedido delas próprias, serão identificados apenas pela numeração de $1 \mathrm{a}$ 8. Como já dito anteriormente, os terminais intermodais rodo-ferroviários utilizados são os de Ribeirão Preto e São Joaquim da Barra, pertencentes à malha da FCA, e o de Engenheiro Schmidt, na malha da Brasil Ferrovias. O destino final de escoamento é o Porto de Santos. A Figura 4.1 do capítulo anterior ilustra o posicionamento geográfico de todos esses pontos relevantes.

O procedimento de simulação neste trabalho seguiu as seguintes etapas:

- Definição dos cenários; 
- Preparação dos campos de custos referentes a cada alternativa tecnológica na base dos dados rodoviários (TransCAD);

- Preparação do arquivo de penalidades (pedágios) para a rede rodoviária (TransCAD);

- Execução da rotina do Problema dos Transportes para alocação de fluxos aos terminais intermodais nos cenários rodo-ferroviários, a cada mês durante a safra (TransCAD);

- Execução da rotina de Caminhos Mínimos para estimar os custos absolutos dos ciclos usina-terminal-usina e usina-porto-usina para cada alternativa tecnológica rodoviária (TransCAD);

- Introdução nas planilhas eletrônicas dos fluxos de transporte de açúcar alocados a cada terminal intermodal mensalmente (Excel);

- Introdução nas planilhas eletrônicas dos custos absolutos dos ciclos usinaterminal-usina e usina-porto-usina (Excel);

- Introdução nas planilhas eletrônicas dos valores de frete relativos ao transporte rodoviário (pontas e porta-a-porta) e ferroviário (custos de transporte e transbordo);

- Estimativa dos custos absolutos totais para cada cenário (Excel).

\subsection{Apresentação dos Cenários}

Os cenários de simulação escolhidos para representar o fenômeno do transporte de açúcar neste estudo de caso são:

- Cenário 1 (Tabela 5.1): estima os custos de transporte numa operação exclusivamente rodoviária, no ciclo usina-porto-usina, para tecnologias atualmente em uso no mercado (2S3 e 3S3) e potenciais (3S2B2 e 3S3B3), sendo que a simulação é feita individualmente para cada tecnologia de transporte. Nesse cenário a frota considerada é própria. 
Tabela 5.1: Descrição do cenário 1

\begin{tabular}{ll}
\hline Modo & Rodoviário \\
\hline Operação & Porta-a-porta \\
\hline Frota Rodoviária & Própria \\
\hline Tecnologia Rodoviária & 2S3 (lotação de 27 toneladas) \\
& 3S3 (lotação de 30 toneladas) \\
& 3S2B2 (lotação de 37 toneladas) \\
& 3S3B3 (lotação de 45 toneladas)
\end{tabular}

- Cenário 2 (Tabela 5.2): assim como no cenário 1, a operação no cenário 2 é exclusivamente rodoviária, no ciclo usina-porto-usina, porém com frota totalmente terceirizada. A CVC escolhida é a 3S3, no entanto, tal fato é apenas ilustrativo, pois atualmente não há diferenciação no frete cobrado pelas empresas de transporte para combinações de 5 ou de 6 eixos, ou seja, independente da combinação, o frete por tonelada permanece o mesmo.

\section{Tabela 5.2: Descrição do cenário 2}

\begin{tabular}{ll}
\hline Modo & Rodoviário \\
\hline Operação & Porta-a-porta \\
\hline Frota Rodoviária & Terceirizada \\
\hline Tecnologia Rodoviária & 3S3 (lotação de 30 toneladas) \\
\hline
\end{tabular}

- Cenário 3 (Tabela 5.3): esse cenário estima os custos de transportes utilizando os modos rodoviários e ferroviários de forma combinada e complementar. Como há limitação de capacidade embarcada no modo ferroviário (apresentado no capítulo 4), todo o excedente que não pode ser embarcado por esse modo é transportado pelo modo rodoviário porta-a-porta. A frota que perfaz os ciclos usina-terminal-usina e 
usina-porto usina é própria, e todas as tecnologias rodoviárias investigadas neste trabalho são simuladas em ambos os trechos individualmente (2S3, 3S3, 3S2B2 e 3S3B3).

Tabela 5.3: Descrição do cenário 3

\begin{tabular}{ll}
\hline Modo & Rodo-ferroviário \\
\hline Operação & Com restrição de capacidade ferroviária \\
\hline Frota Rodoviária & Própria \\
\hline Tecnologia Rodoviária & 2S3 (lotação de 27 toneladas) \\
& 3S3 (lotação de 30 toneladas) \\
& 3S2B2 (lotação de 37 toneladas) \\
& 3S3B3 (lotação de 45 toneladas) \\
\hline
\end{tabular}

- Cenário 4 (Tabela 5.4): esse cenário é similar ao cenário 3, a exceção de que a frota rodoviária utilizada para os trechos usina-terminal-usina e usina-porto-usina é toda terceirizada.

Tabela 5.4: Descrição do cenário 4

\begin{tabular}{ll}
\hline Modo & Rodo-ferroviário \\
\hline Operação & Com restrição de capacidade ferroviária \\
\hline Frota Rodoviária & Terceirizada \\
\hline Tecnologia Rodoviária & 3S3 (lotação de 30 toneladas) \\
\hline
\end{tabular}

- Cenário 5 (Tabela 5.5): esse cenário rodo-ferroviário é considerado hipotético, pois atualmente não há operação ferroviária de transporte de açúcar sem restrição de embarque, ao menos na região englobada por esse estudo de caso. Isso quer dizer que toda a demanda por transporte de açúcar das usinas do conglomerado poderia ser 
suprida pelo transporte ferroviário. Na ponta rodoviária é utilizada frota própria, sendo que em cada simulação é considerada uma tecnologia diferente de CVC.

Tabela 5.5: Descrição do cenário 5

\begin{tabular}{ll}
\hline Modo & Rodo-ferroviário \\
\hline Operação & Sem restrição de capacidade ferroviária \\
\hline Frota Rodoviária & Própria \\
\hline Tecnologia Rodoviária & 2S3 (lotação de 27 toneladas) \\
& 3S3 (lotação de 30 toneladas) \\
& 3S2B2 (lotação de 37 toneladas) \\
\hline
\end{tabular}

- Cenário 6 (Tabela 5.6): assim como o cenário 5, este também é um cenário rodoferroviário hipotético, por não apresentar restrição de embarque de açúcar nos terminais intermodais. No entanto, aqui são estimados os custos de transporte agregados dos dois modos, onde a operação da ponta rodoviária é feita com frota terceirizada.

Tabela 5.6: Descrição do cenário 6

\begin{tabular}{ll}
\hline Modo & Rodo-ferroviário \\
\hline Operação & Sem restrição de capacidade ferroviária \\
\hline Frota Rodoviária & Terceirizada \\
\hline Tecnologia Rodoviária & 3S3 (lotação de 30 toneladas) \\
\hline
\end{tabular}




\subsection{Preparação do banco de dados do TransCAD}

Para que o software TransCAD possa encontrar o caminho mínimo entre as diversas origens e destinos simulados, é necessário que os arcos que compõem a rede rodoviária sejam carregados com custos relativos às suas transposições.

A atribuição dos custos em cada arco varia, portanto, em função do custo operacional por quilômetro modelado para cada alternativa tecnológica no modo rodoviário. Assim, os campos GRANEL(R\$), BASCULANTE(R\$), BITREM7(R\$) e BITREM9(R\$) (Figura 4.2) referentes aos custos dos arcos são preenchidos genericamente da seguinte maneira:

$\operatorname{CUSTO}_{\text {arco }}(R \$)=$ Length $\times$ custo $_{\text {operacional }}$

onde,

CUSTO $_{\text {arco: }}$ : custo absoluto em cada arco da rede para cada alternativa tecnológica utilizada (graneleira 5 eixos, basculante de 6 eixos, bitrem de 7 e 9 eixos) (R\$);

Length: comprimento do arco (km);

Custo $_{\text {operacional: }}$ custo operacional modelado para cada alternativa tecnológica $(\mathrm{R} \$ / \mathrm{km})$.

\subsection{Preparação do Arquivo de Penalidades (pedágios)}

As penalidades impostas à rede rodoviária modelada são referentes aos pedágios cobrados nas rodovias estaduais e federais da malha do Estado de São Paulo. Sempre que há fluxo entre dois arcos adjacentes, os quais possuem um ponto de penalidade intermediário, é adicionado um valor arbitrado de penalidade.

Como os custos atribuídos aos arcos estão em unidade de valor absoluto (R\$), é necessário que as penalidades obedeçam ao mesmo padrão de unidades. Para isso, calculam-se previamente todas as tarifas de pedágio em valor absoluto, referente a cada alternativa tecnológica, as quais possuem valores diferentes em função da variação do número de eixos. 
Em seguida, deve-se preparar um arquivo em planilha Excel apenas com os IDs (código de identificação) dos arcos à jusante e montante dos pontos de penalidades, respeitando o sentido da cobrança, e seus respectivos valores de pedágios. Esse arquivo que possui os campos FROM, TO e PENALTY, é carregado sempre antes do início da simulação, dependendo da combinação que será utilizada.

\subsection{Execução da Rotina do Problema dos Transportes para o Modelo Rodo- Ferroviário}

No modelo ferroviário onde os terminais intermodais apresentam restrições de capacidade no carregamento de açúcar, é necessário que se atribua a cada usina do conglomerado qual a tonelagem específica mensal que deve ser embarcada durante a safra.

Para solucionar este problema, aplicou-se nessa simulação, uma rotina do Problema dos Transportes. Nessa rotina, as usinas que apresentam custos de transporte menores em relação a um terminal intermodal têm prioridade de embarque de açúcar. A atribuição de carregamento de açúcar das usinas acontece até que a capacidade do terminal seja atingida.

Inicialmente deve-se construir uma matriz de custos mínimos múltiplos entre as origens e os destinos desejados. Dependendo do cenário, esse par origem-destino pode ser entre as usinas e o porto, ou entre as usinas e os terminais intermodais. No entanto, o procedimento de execução da rotina é similar para ambos. A Figura 5.1 apresenta uma matriz de custos mínimos entre usinas e terminais intermodais. Nessa simulação, o tipo da CVC carregada na rede não interfere na alocação final dos fluxos. Isso porque, quando se alteram os custos nos arcos em função do tipo de CVC e das penalidades, a proporcionalidade entre esses custos é mantida, e a distribuição permanece a mesma. 


\begin{tabular}{|c|c|c|c|}
\hline 萑腊253_cen3.myw & ew Matrix File [I & EL [Rs]]] & - \\
\hline & Eng. Schmidt & S. J. Barra & Ribeirāo Preto \\
\hline Usina 6 & 350.84 & 660.43 & 713.94 \\
\hline Usina 4 & 178.07 & 368.51 & 422.02 \\
\hline Usina 5 & 233.08 & 135.02 & 290.45 \\
\hline Usina 1 & 340.96 & 29.91 & 161.33 \\
\hline Usina 3 & 291.45 & 94.57 & 197.33 \\
\hline Usina 2 & 330.01 & 191.69 & 86.57 \\
\hline Usina 7 & 401.89 & 105.82 & 55.35 \\
\hline Usina 8 & 451.36 & 570.42 & 426.24 \\
\hline
\end{tabular}

Figura 5.1: Matriz dos múltiplos caminhos de menores custos entre usinas e terminais intermodais.

Em seguida, devem-se inserir as demandas por transporte e as capacidades de carregamento nos bancos de dados das usinas e terminais respectivamente. Nesse caso, a cada mês da safra deve-se fazer uma atualização, para que diferentes fluxos sejam atribuídos mensalmente. As Figuras 5.2 e 5.3 mostram esses bancos de dados preenchidos para o mês de dezembro, como exemplo.

\begin{tabular}{|c|c|c|c|}
\hline \multicolumn{3}{|c|}{ 醀Datayiew1 - usinas } & - \\
\hline ID & Longitude & Latitude & Demanda|Empresas \\
\hline 7303 & -47998194 & -20618583 & 31500.00 Usina 1 \\
\hline 7306 & -48074722 & -21111667 & 0.00 Usina 2 \\
\hline 7304 & -48201943 & -20781943 & 8000.00 Usina 3 \\
\hline 7297 & -49356766 & -20236419 & 23500.00 Usina 4 \\
\hline 7299 & -48407501 & -20480000 & 15000.00 Usina 5 \\
\hline 7292 & -50942501 & -20727222 & 8173.00 Usina 6 \\
\hline 7308 & -47878861 & -20943278 & 12000.00 Usina 7 \\
\hline 7310 & -48107896 & -22349458 & 9000.00 Usina 8 \\
\hline
\end{tabular}

Figura 5.2: Banco de dados referente às usinas contendo a demanda por transporte de açúcar do mês de dezembro.

\begin{tabular}{|c|c|c|c|c|}
\hline \multicolumn{4}{|c|}{ in Dataview1 - terminais } & $-\nabla \mid x$ \\
\hline ID & Longitude & Latitude & Capacidade Terminal & \\
\hline 7314 & -47879270 & -20572104 & 22500.00 S. J. Barra & \\
\hline 7321 & -47795796 & -21138426 & 22500.00 Ribeirāo Preto & \\
\hline 7313 & -49310057 & -20869647 & 10000.00 Eng. Schmidt & \\
\hline
\end{tabular}

Figura 5.3: Banco de dados referente aos terminais intermodais contendo as capacidades de embarque de açúcar no mês de dezembro. 
Com a matriz de custos mínimos entre origens e destinos, e suas respectivas demandas por transporte e capacidade inseridas, é possível executar a rotina Transportation Problem do TransCAD. A matriz de saída de resultados apresenta por fim, quanto cada usina deve carregar de açúcar em cada um dos terminais intermodais, como mostra a Figura 5.4, a exemplo do mês de dezembro. Percebe-se pela figura que, uma mesma usina, dependendo de sua distância ao terminal, da demanda por transporte, e da capacidade do terminal, pode embarcar em mais de um terminal no mesmo mês.

Assim, esse procedimento é seguido análogo para todos os meses da safra, fazendo-se sempre as devidas alterações necessárias mostradas acima.

\begin{tabular}{|c|c|c|c|}
\hline \multicolumn{3}{|c|}{ 隹 253_12.myw - Transportation Problem [Flow] } & -0 \\
\hline & Eng. Schmidt & S. J. Barra & Ribeirāo Preto \\
\hline Usina 6 & -- & - & -- \\
\hline$U \sin a 4$ & 10000.00 & -- & -- \\
\hline Usina 5 & -- & -- & -- \\
\hline Usina 1 & -- & 22500.00 & 9000.00 \\
\hline Usina 3 & -- & -- & 1500.00 \\
\hline Usina 2 & -- & -- & - \\
\hline Usina 7 & -- & -- & 12000.00 \\
\hline Usina 8 & -- & -- & -- \\
\hline
\end{tabular}

Figura 5.4: Matriz de alocação dos fluxos de transporte de açúcar entre usinas e teminais intermodais.

\subsection{Execução da Rotina de Caminhos Mínimos para Frota Própria}

Para as simulações que envolvem frota própria, é necessário calcular inicialmente os custos absolutos de transporte nos ciclos, podendo estes ser entre as usinas e o porto, ou entre as usinas e os terminais intermodais.

Dessa forma, pode-se estimar os custos das viagens nos ciclos pela rotina Shortest Path do TransCAD. Nessa rotina, deve-se fazer a seleção dos pontos de origem e destino, carregar as penalidades relativas à tecnologia que se deseja simular, e indicar qual o campo de custos que deve ser utilizado (GRANEL(R\$), BASCULANTE(R\$), $\operatorname{BITREM7(R\$ )~ou~BITREM9(R\$ )).~}$ 
Assim, uma simulação diferente deve ser feita para cada alternativa tecnológica, variando dentro dos cenários rodoviário porta-a-porta e rodo-ferroviário que utilizam frota própria.

As Figuras 5.5 e 5.6 mostram exemplos de saídas de resultados de uma simulação, envolvendo as usinas do conglomerado e o terminal intermodal de São Joaquim da Barra, para CVCs tipo 3S3B3. Os resultados dessa rotina são apresentados em forma de mapas contendo as rotas de caminhos mínimos e um banco de dados com as distâncias percorridas e respectivos custos de transporte.

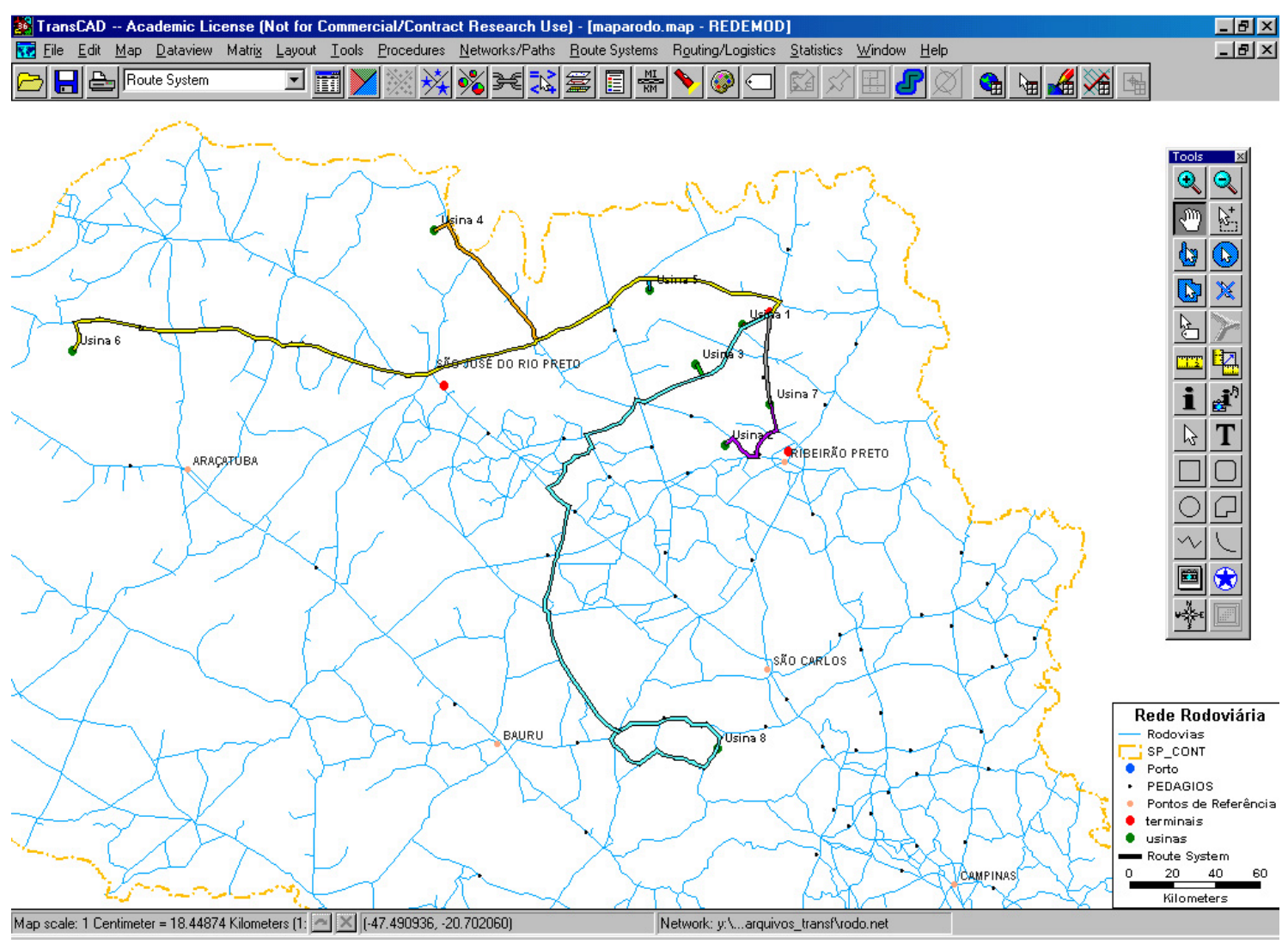

Figura 5.5: Mapa de caminhos mínimos no ciclo usina-terminal-usina. 


\begin{tabular}{|r|r|r|r|}
\hline \multicolumn{7}{|c|}{ Dataview1 - Route System } & $-\mid \square]$ \\
\hline ID & \multicolumn{1}{|c|}{ Length $\mid$ Dir| Trajeto } & [3S3B3 [R\$)] \\
\hline 9 & 33.23 & 1 Usina 1 - SJB - Usina 1 & 79.75 \\
10 & 181.88 & 1 Usina 2 - SJB - Usina 2 & 436.52 \\
11 & 105.08 & 1 Usina 3 - SJB - Usina 3 & 252.19 \\
12 & 409.45 & 1 Usina 4 - SJB - Usina 4 & 982.69 \\
13 & 150.03 & 1 Usina 5 - SJB - Usina 5 & 360.06 \\
14 & 733.82 & 1 Usina 6 - SJB - Usina 6 & 1761.16 \\
15 & 86.47 & 1 Usina 7 - SJB - Usina 7 & 207.53 \\
16 & 670.53 & 1 Usina 8 - SJB - Usina 8 & 1609.27 \\
\hline
\end{tabular}

Figura 5.6: Custos mínimos absolutos relativos a um ciclo usina-terminal-usina utilizando uma CVC tipo 3S3B3.

\subsection{Simulações com Frota Terceirizada}

Antes de apresentar a parte final das simulações dos cenários em planilhas eletrônicas, é necessário fazer uma ressalva sobre a lógica da simulação adequada às frotas terceirizadas, mais especificamente, a todos que utilizam o frete (R\$/ton) como unidade de valor, como também é o caso do transporte ferroviário.

Nesses casos, onde as informações de valor de frete coletadas estão expressas em unidade de valor por tonelada, a solução para saber o quanto se despende mensalmente com transportes é direta, e depende exclusivamente do quanto é transportado e do frete cobrado. Ou seja, nas planilhas eletrônicas, ao invés de um campo com os custos das viagens nos ciclos, como nos cenários com frota própria, optou-se pelo valor do frete por tonelada, que multiplicado pela demanda por transporte mensal de uma usina, resulta no custo absoluto despendido diretamente, independente do número de viagens, da CVC utilizada ou do número de vagões, por exemplo.

Esse procedimento adotado, embora simples, ajudou para a simulação em conjunto principalmente nos cenários rodo-ferroviários. Isso porque, as unidades de custos fornecidas diretamente pelo modelo de custos rodoviários são diferentes das unidades de frete coletadas. Essa não conformidade de unidades impediu que um modelo de rede rodo-ferroviário integrado fosse utilizado, para evitar que alguma distorção pudesse influenciar os resultados das simulações. 
Por outro lado, o tipo de simulação disponível no software TransCAD é do tipo estática, e nesse caso, não há compreensão pelo programa, da diferença de ordem de grandeza nas lotações das CVCs e das composições ferroviárias, até porque, as composições ferroviárias têm suas lotações variáveis em função do número de vagões. Assim, a dinâmica do transporte intermodal prevê que várias viagens de CVCs sejam necessárias para suprir o carregamento de uma composição ferroviária, seja estabelecendo armazenagem nos terminais intermodais, ou descarregando direto nos vagões, o que não é possível de simular no TransCAD.

Percebeu-se, ao final, que o emprego de planilhas eletrônicas, abordando o transporte rodoviário e ferroviário separadamente, permitia que tais problemas não influenciassem o resultado final do trabalho.

\subsection{Cálculo Final dos Custos Absolutos de Transporte no Estudo de Caso}

Após a execução das etapas de preparação de dados, como comentado até aqui, são calculados efetivamente os custos absolutos mensais de transporte para todos os cenários propostos. Nessa última etapa, todas os cálculos são executados em planilhas eletrônicas do Excel.

Em virtude do grande número de planilhas geradas para simular todos os cenários possíveis, optou-se por apresentar no Apêndice J, um exemplo de cálculo dos custos absolutos para todos os cenários num determinado mês (dezembro/04) e uma alternativa de CVC (3S3B3), no caso das simulações que envolvem frota própria.

A primeira consideração sobre as planilhas de simulação diz respeito ao campo de número de viagens nos cenários que utilizam frota própria (1, 3 e 5). Em função da lotação das CVCs e da demanda por transportes de cada usina por mês, o número de viagens necessárias para suprir essa demanda também é variável. Essa precaução faz com que a simulação independa do tamanho da frota de quem é responsável pelo transporte da carga.

Os campos com as variáveis de carregamento são utilizados em todos os cenários, uma vez que essa é quem determina a tonelagem transportada por cada modo de transporte (rodoviário ou ferroviário). Percebe-se pelos exemplos do Apêndice J que, 
nos cenários exclusivamente rodoviários (1 e 2), 100\% do carregamento de açúcar deve ser feito pelo modo rodoviário; nos cenários 3 e 4, a tonelagem de carregamento é determinada pelos resultados provenientes da rotina do Problema dos Transportes descritos anteriormente; e os cenários 5 e 6, por não apresentarem limitações de capacidade no transporte ferroviário, têm 100\% dos seus carregamentos por este modo. É válido recordar que nos Cenários 3 e 4, o carregamento que excede o limite de capacidade dos terminais intermodais é todo alocado para a planilha de transporte rodoviário porta-a-porta complementar similar ao do Cenário 1.

Os campos de custos das viagens são provenientes da simulação dos Caminhos Mínimos. No Cenário 1, considera-se os custos da viagens usina-porto-usina; no Cenário 3, consideram-se os custos das viagens usina-porto-usina e usina-terminalusina; e no Cenário 5, apenas os custos das viagens usina-terminal-usina. Isso acontece em função das características assumidas nas definições dos cenários.

Os fretes para o transporte rodoviário porta-a-porta e das pontas são inseridos a partir dos dados coletados junto à trading do conglomerado e as próprias usinas, e utilizados nos Cenários 2, 4 e 6.

Os fretes ferroviários de operação e transbordo, utilizados nos Cenários 3, 4, 5 e 6, são todos fixos, e multiplicados pelas tonelagens carregadas, fornecem os custos ferroviários relativos a cada usina. Para esses mesmos cenários, os campos de custos rodo-ferroviários fornecem por fim, a soma dos custos rodoviários que perfazem a ponta (próprios ou terceirizados) mais os custos ferroviários (operação e transbordo).

Além dessas informações, as planilhas dos cenários rodo-ferroviários ainda apresentam as tonelagens carregadas entre os modos rodoviário e rodo-ferroviário, e seus respectivos custos relativos percentuais.

Os custos absolutos finais são, portanto:

- No Cenário 1: o produto dos custos das viagens pelo número de viagens necessárias para suprir a demanda;

- No Cenário 2: o produto do frete rodoviário pela demanda por transporte de açúcar ; 
- Nos Cenários 3 e 4: a somatória dos custos da ponta rodoviária, da operação ferroviária e do rodoviário complementar;

- Nos Cenários 5 e 6: a somatória dos custos da ponta rodoviária e da operação ferroviária.

No Apêndice K apresentam-se os resumos dos custos absolutos de transporte em cada cenário apresentado, sem a riqueza dos detalhes dispostas no exemplo do Apêndice J. Esses quadros resumos contêm especificamente os dados utilizados para a montagem dos gráficos das análises dos resultados do próximo capítulo. 


\section{ANÁLISE E DISCUSSÃO DOS RESULTADOS}

Nesse capítulo serão apresentados e discutidos os resultados gerados pelas simulações dos cenários enunciados no Capítulo 5. A organização das análises acontece em função dos objetivos estipulados no início deste trabalho.

As características dos cenários estabelecidos neste trabalho permitem um agrupamento das análises em três grupos de opções de transporte: o rodoviário porta-aporta; o rodo-ferroviário com restrição de capacidade de embarque de açúcar; e o rodoferroviário sem restrição de capacidade de embarque de açúcar. Em cada um desses grupos existe a opção de se transportar nos trechos rodoviários, tanto no porta-a-porta como nas pontas, operando frota própria ou terceirizada. O objetivo é, portanto, apresentar a opção mais vantajosa, em termos de custo absoluto, dentro de cada grupo de análise e no conjunto global dos cenários.

Além disso, por meio de análises de sensibilidade, exploram-se relações entre algumas variáveis envolvidas na modelagem para ilustrar alternativas não previstas inicialmente ou para complementar justificativas sobre determinada análise.

\subsection{Transporte Rodoviário Porta-a-Porta: Análise dos Cenários 1 e 2}

A partir dos resultados apresentados no Apêndice K são construídas as Figuras 6.1 e 6.2, as quais comparam a competitividade existente entre as novas CVCs propostas para o mercado de açúcar (3S2B2 e 3S3B3) e as atualmente utilizadas (2S3 e 3S3). Percebe-se pela Figura 6.1 que frente às alternativas correntes, o 3S2B2 - que já tem permissão de tráfego sem AET, mas tem uso incipiente nesse mercado - apresenta viabilidade econômica em sua utilização, pois a custos relativamente inferiores (10\% e 3,5\% sobre o $2 \mathrm{~S} 3$ e o 3S3, respectivamente) a combinação pode transportar maior carga líquida (37\% e 23,3\% a mais do que no 2S3 e 3S3). O mesmo acontece para o 3S3B3, que dentre todas as alternativas tecnológicas rodoviárias, apresentou a melhor relação custo - capacidade de carga. Como mostra a Figura 6.2, o 3S3B3 possui, pelos resultados da simulação, 20,7\% de vantagem sobre os custos do 2S3, $13 \%$ sobre 
os do $3 \mathrm{~S} 3$ e $9,2 \%$ sobre os do 3S2B2; e pode transportar $66,7 \%, 50,0 \%$ e $21,6 \%$ a mais do que essas CVCs na mesma ordem.

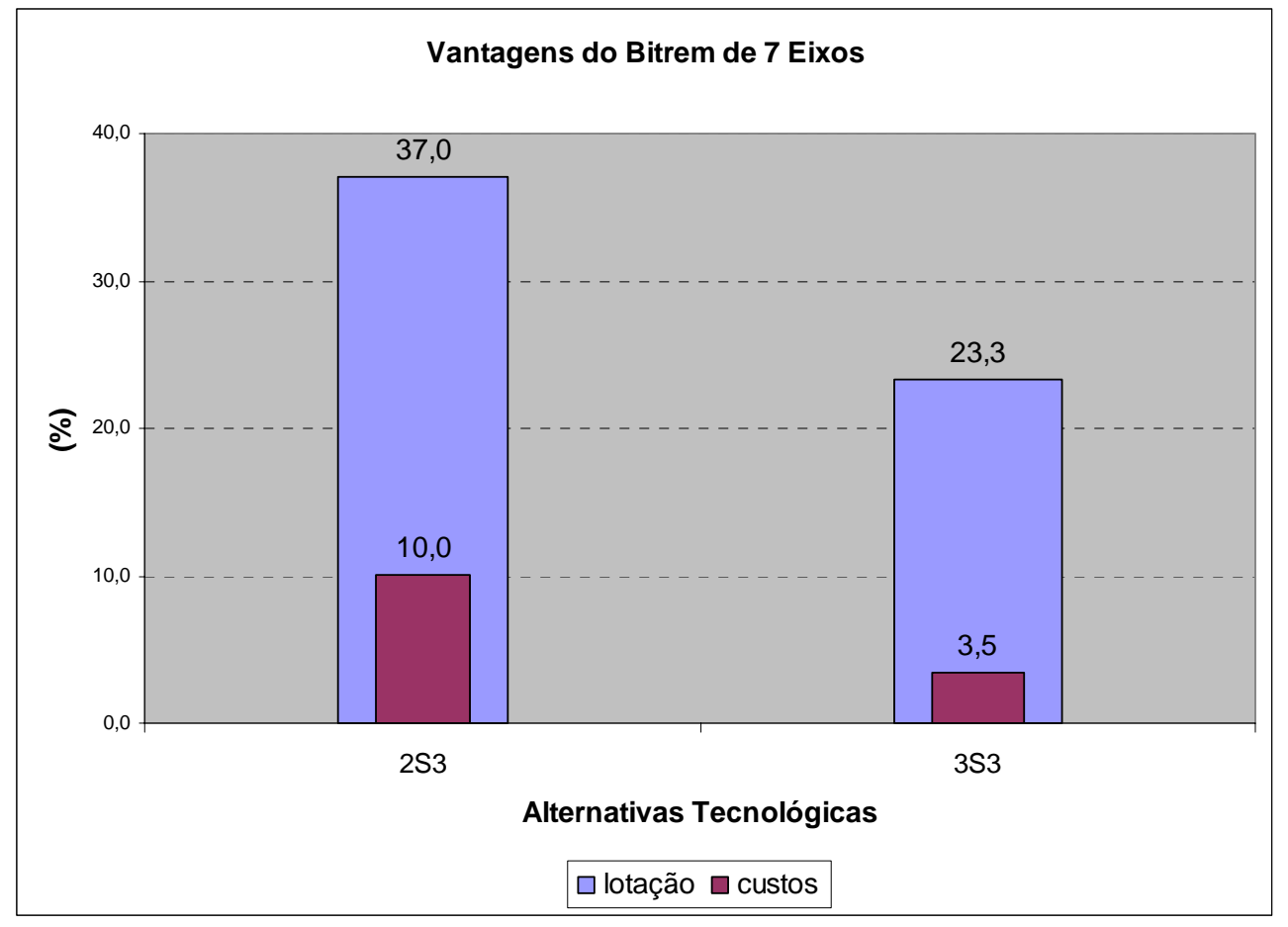

Figura 6.1: Vantagem competitiva do 3S2B2 sobre o 2S3 e o 3S3.

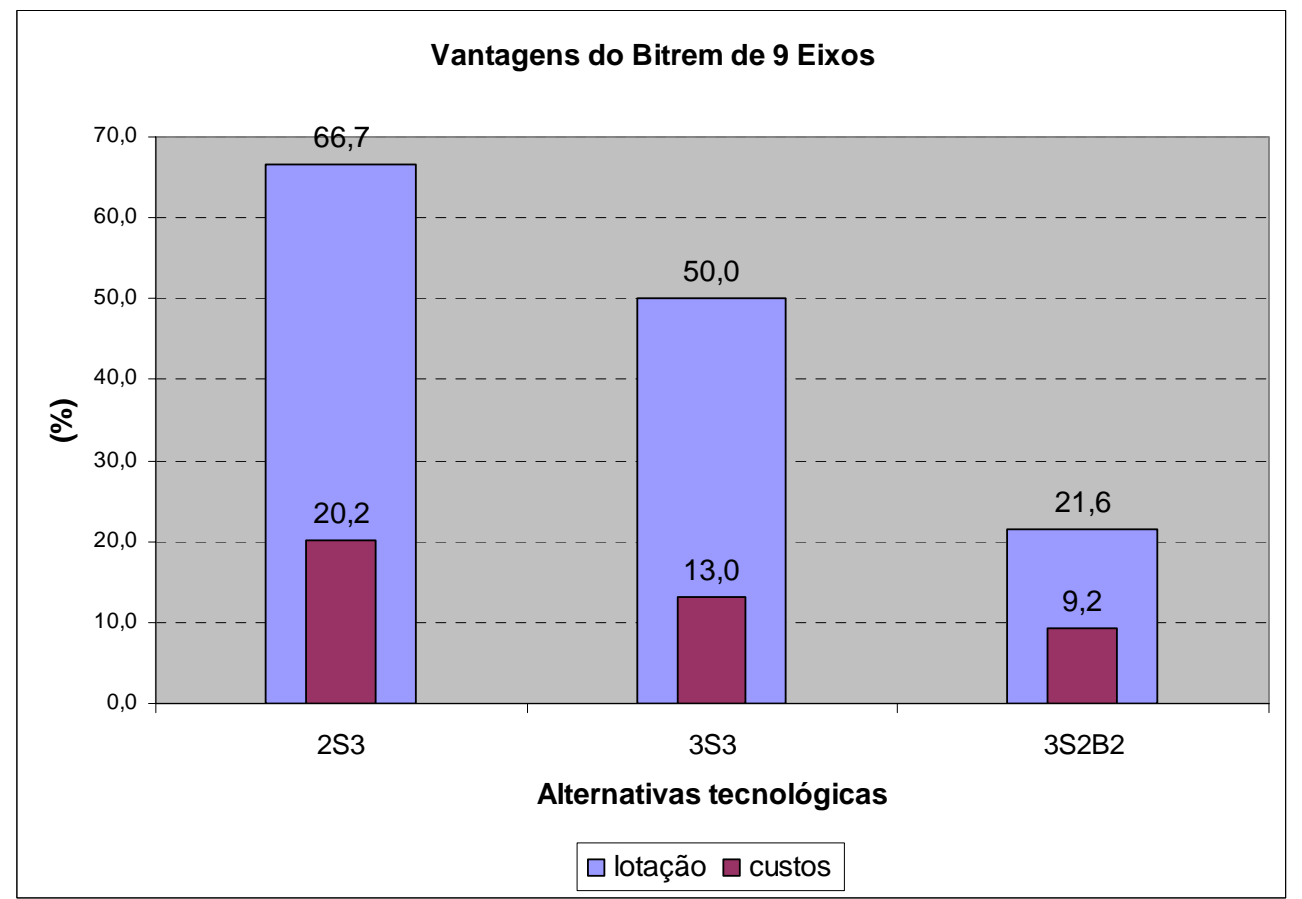

Figura 6.2: Vantagem competitiva do 3S3B3 sobre as alternativas rodoviárias. 
É importante destacar as competitividades das novas sobre as atuais tecnologias rodoviárias, pois essas devem apontar, em virtude dos resultados apresentados, uma nova tendência de investimento dos transportadores do mercado de açúcar em combinações que, dentre outras benefícios, diminuem os custos unitários e danificam menos os pavimentos.

Para analisar a competitividade econômica entre os Cenários 1 e 2, construiu-se a Figura 6.3 com as curvas que mostram os custos absolutos de cada alternativa ao longo da safra 2004/2005. É conveniente explicar que as formas das curvas de custos absolutos se dão em função da curva de produção total das usinas a cada mês, como mostra a Figura 6.4.

Da Figura 6.3 percebe-se claramente a vantagem econômica (na visão do conglomerado como um todo) de se contratar uma empresa de transportes ao invés de operar frotas próprias no transporte de açúcar no percurso usina-porto-usina, independente da CVC adotada. Essa é uma constatação relevante visto que, teoricamente, os custos absolutos deveriam ser mais baixos do que os custos despendidos com o transporte terceirizado. No entanto, como dito no capítulo de modelagem, os resultados apresentados são decorrentes dos parâmetros e hipóteses assumidos pelo modelo. Por esse motivo, algumas variáveis que podem estar causando esta discrepância serão avaliadas na análise de sensibilidade mais adiante, tais como: taxa de retorno, quilometragem percorrida mensalmente e parcelas do custo fixo (remuneração de capital, depreciações, seguros e monitoramento por satélite). 


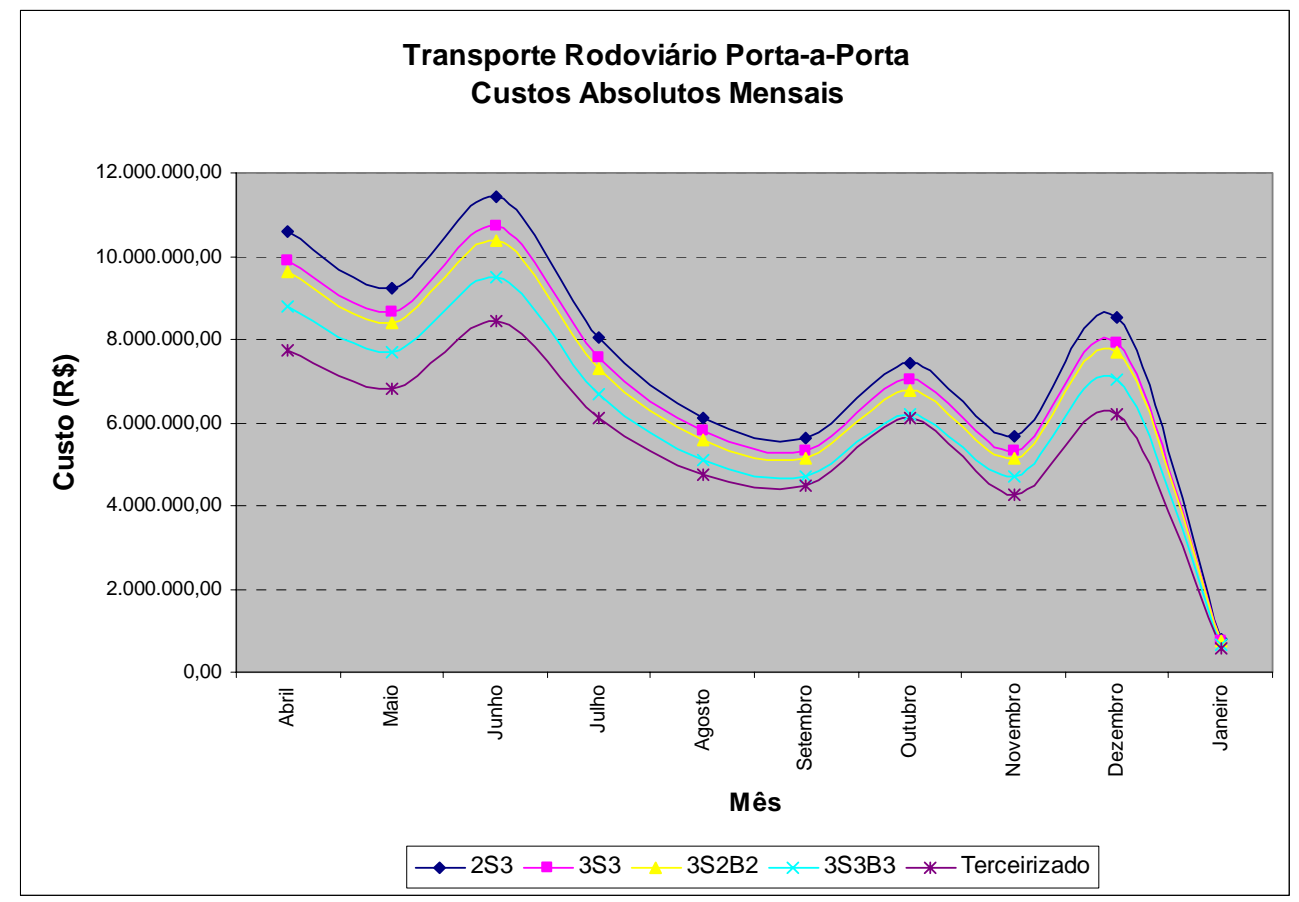

Figura 6.3: Custos absolutos de transporte nas alternativas dos Cenários 1 e 2.

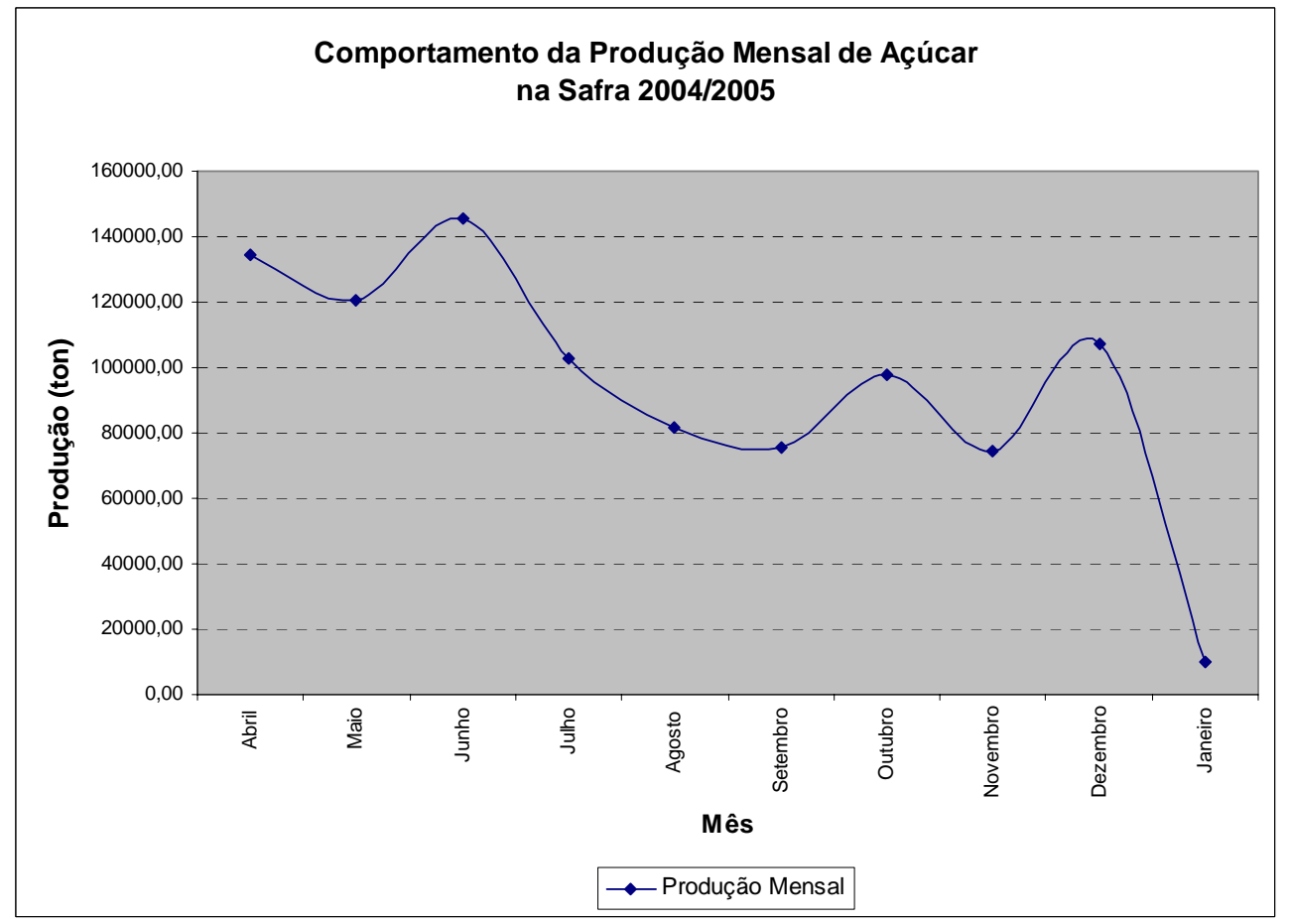

Figura 6.4: Produção mensal de açúcar ao longo da safra 2004/2005 para o conglomerado de usinas.

A Figura 6.5 mostra as vantagens econômicas que o transporte porta-a-porta terceirizado apresenta sobre as operações com frota própria. A princípio, portanto, em se tratando da estratégia a ser adotada por um conglomerado na definição do transporte 
porta-a-porta, é mais interessante economicamente buscar parceiros para desempenhar o serviço ao invés de investir em sua própria frota. No entanto, cabe ao contratante do transporte, incitar o parceiro de negócio a adquirir novas tecnologias de CVCs, ou mesmo propor uma parceria na aquisição de cavalos mecânicos e/ou implementos, uma vez que essa adoção acarretaria na diminuição dos valores do frete para o mesmo, desde que houvesse infra-estrutura compatível em terminais e vias. Isso porque, por analogia a Figura 6.2, se a empresa de transportes consegue operar uma CVC $3 \mathrm{S3}$ a um determinado nível de frete, teoricamente o frete para uma CVC 3S3B3 deveria ser da ordem de $13 \%$ mais baixo.

Todavia, deve-se mencionar que tal medida causaria impactos na classe transportadora, principalmente para os autônomos, como descrevem Danilevicz et al. (2003). Por conseqüência à queda do valor do frete causada pela entrada de novas CVCs, os transportadores autônomos seriam obrigados também a baixar seus fretes para entrar na divisão do mercado. Nesse contexto de queda do frete, os transportadores autônomos estariam trabalhando abaixo dos custos econômicos, o que de imediato causa problemas sócio-econômicos para os motoristas, em função da queda dos rendimentos da atividade, e promove o envelhecimento da frota nacional, em função da falta de capital para troca das combinações.

Tal impasse deve então ser tratado com cuidado pelo poder público, associações da classe, academia e sociedade. Nesse caso, a regulamentação das atividades do transporte rodoviário se faz necessária para manter níveis aceitáveis e justos de rentabilidade e custeio para os envolvidos. 


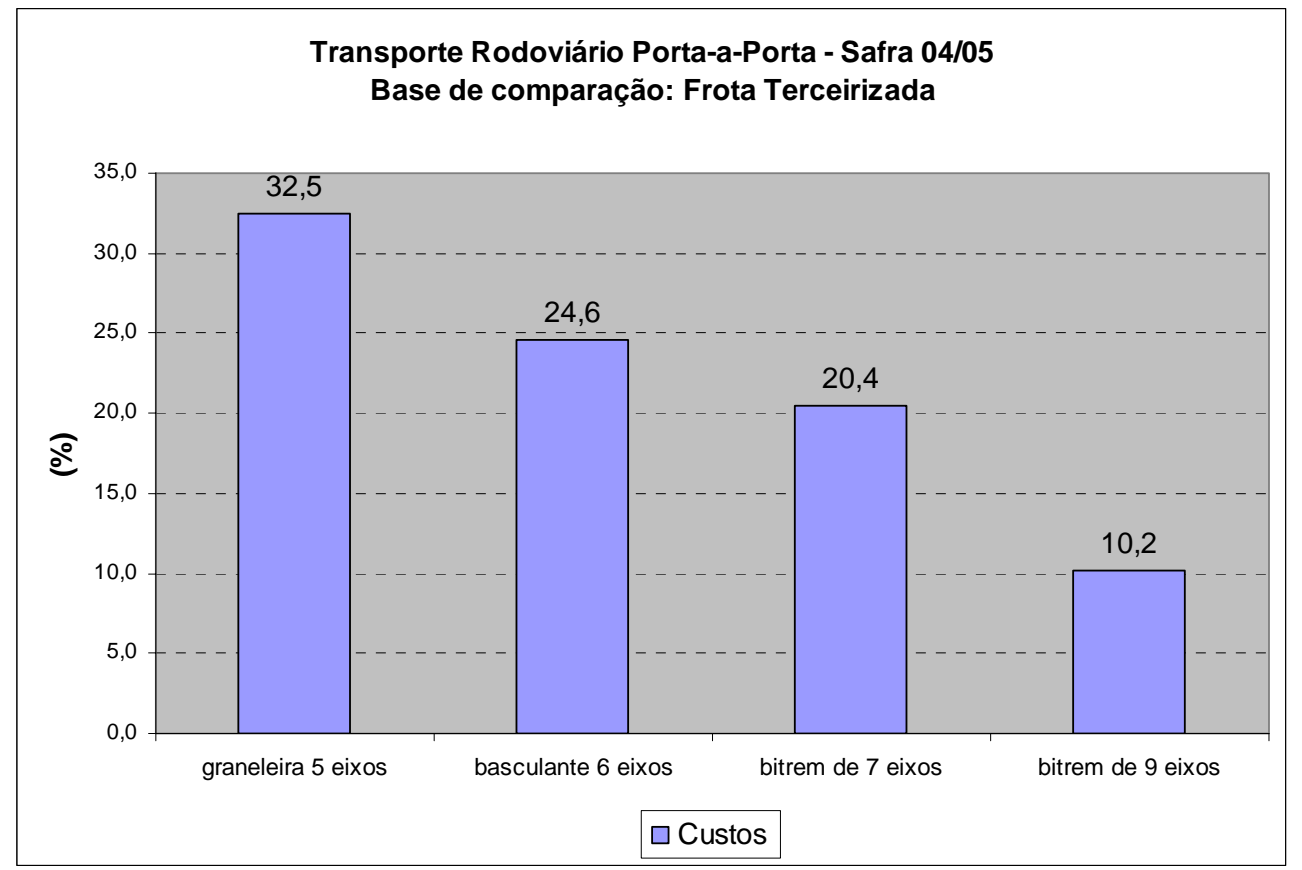

Figura 6.5: Vantagem econômica da operação com frota terceirizada sobre a operação com frota própria.

A última análise referente ao transporte rodoviário porta-a-porta diz respeito à vantagem econômica relativa das frotas terceirizadas sobre as frotas próprias numa avaliação mês a mês, como mostra a Figura 6.6. Essa avaliação é interessante, pois, embora na avaliação global da safra a vantagem dos terceirizados seja ampla, existem meses que essa diferença diminui, podendo chegar a quase $0 \%$, como é o caso do 3S3B3 no mês de outubro da safra 2004/2005. Isso se deve ao comportamento dos fretes cobrados para o transporte de açúcar, que em média seguem o padrão mostrado na Figura 6.7, com tendência de alta entre os meses de maio a outubro, e baixa de outubro até o início da próxima safra. Dessa forma, as vantagens relativas dos custos tendem a baixar à medida que os valores dos fretes cobrados às usinas sobem e permanecem em alta, e vice-versa. 


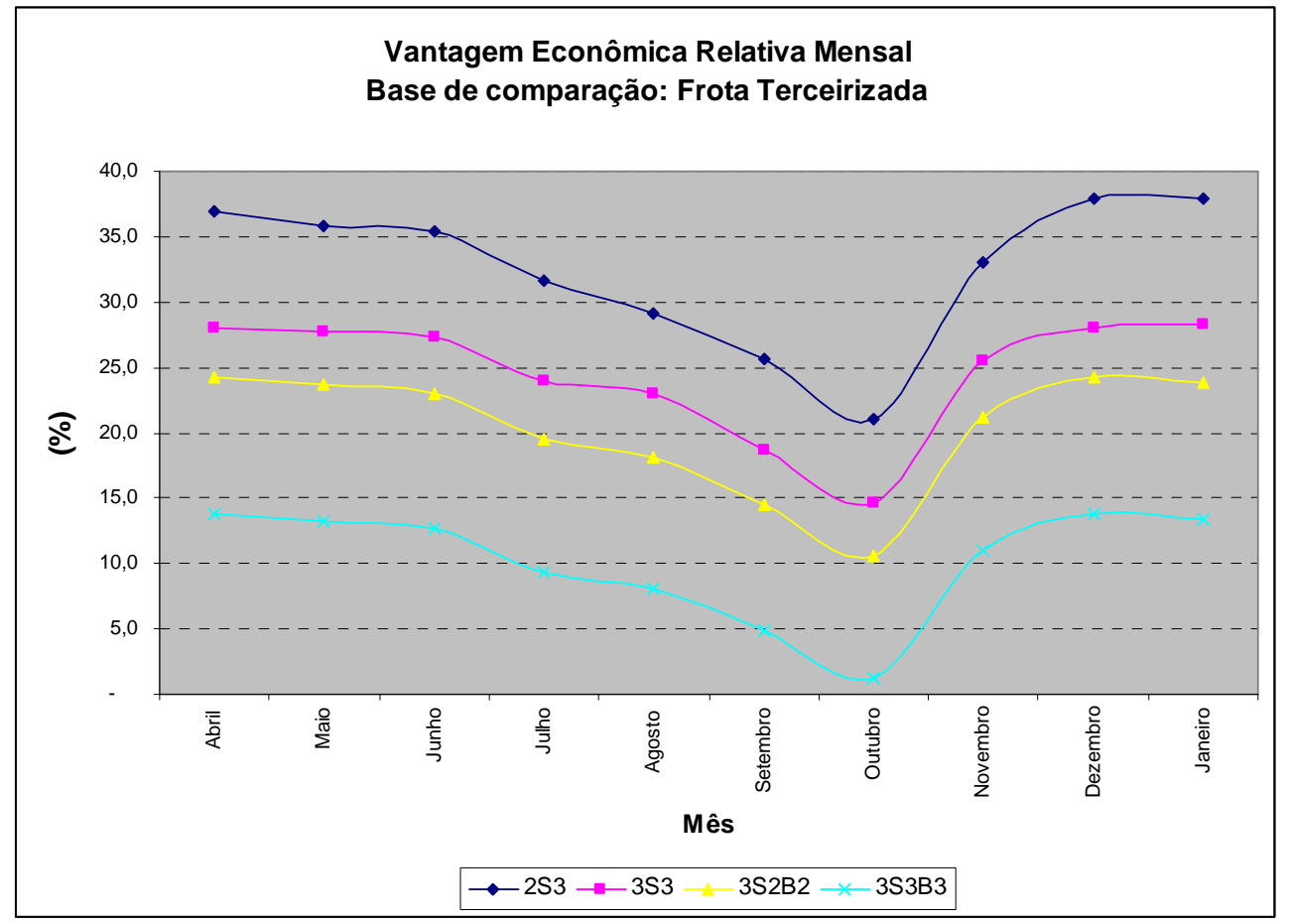

Figura 6.6: Vantagem econômica relativa mensal da operação com frota terceirizada.

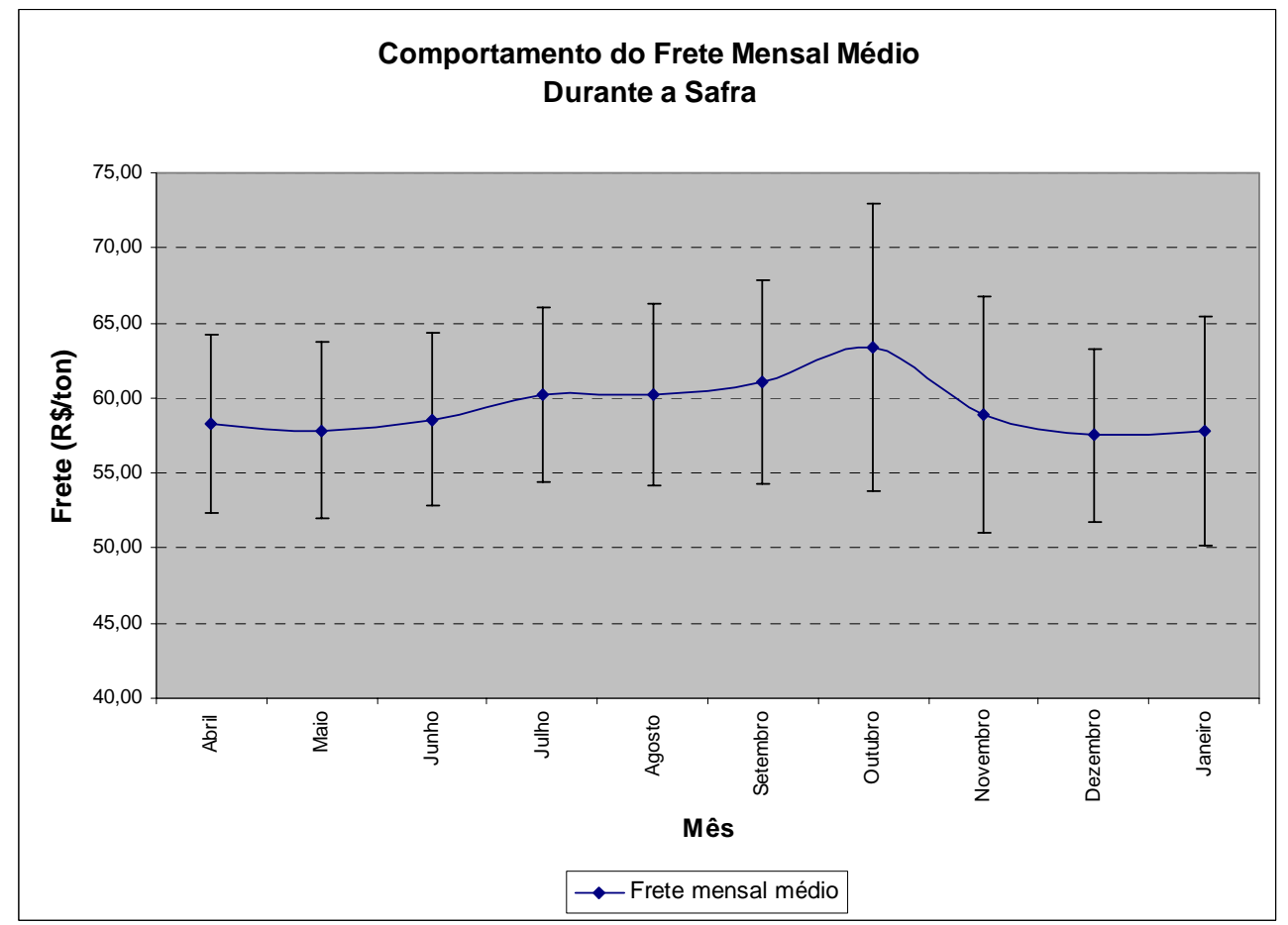

Figura 6.7: Frete mensal médio e intervalo de confiança de fretes observados entre usinas mês a mês. 


\subsection{Transporte Rodo-Ferroviário com Restrição de Capacidade: Análise dos Cenários 3 e 4.}

Os Cenários 3 e 4 são os retratos atuais do transporte de açúcar para o conglomerado investigado nesse estudo de caso. As limitações de embarque de açúcar por parte das ferrovias são acordadas em contratos comerciais entre as concessionárias e os demandantes por transportes (tradings, cooperativas e usinas individuais). Esses limites dependem a princípio, de quantos vagões, trações e área de armazenagem as concessionárias podem disponibilizar para o transporte do produto demandado.

Para analisar os ganhos econômicos gerados pela introdução do transporte ferroviário, construíram-se as curvas de custos absolutos mensais despendido pelo conglomerado durante a safra 2004/2005. Comparando a Figura 6.8 com os resultados apresentados na Figura 6.3, percebe-se numa primeira análise visual, que o conjunto de resultados gerados para o transporte rodo-ferroviário possui ordens de grandeza menores do que no transporte porta-a-porta. Foi introduzida também na Figura 6.8 a curva de custos da operação com frota terceirizada, a qual apresentou a maior competitividade entre alternativas porta-a-porta.

Percebe-se mais uma vez que, a opção de contratar transportes no mercado para execução das pontas e do excedente não transportado pela ferrovia é a alternativa mais viável economicamente dentre as possibilidades apresentadas, inclusive do que o transporte rodoviário porta-a-porta terceirizado.

Um aspecto importante que a análise dos Cenários 3 e 4 permite fazer, é que a vantagem relativa do transporte rodo-ferroviário utilizando frota terceirizada nas pontas e no complementar diminui frente as outras alternativas de combinação rodoviária rodo-ferroviária, como mostra a Figura 6.9. Essas vantagens caem de 32,5\%, 24,6\%, 20,4\% e 10,2\% (Figura 6.3) para 19,8\%, 14,5\%, 11,0\% e 4,5\%, nas CVCs 2S3, 3S3, 3S2B2 e 3S3B3, respectivamente. Deduz-se pela comparação dos resultados das Figuras 6.3 e 6.9 que isso se deve a cobrança de valores de frete por tonelada quilômetro nas pontas mais alta que os cobrados no porta-a-porta. 


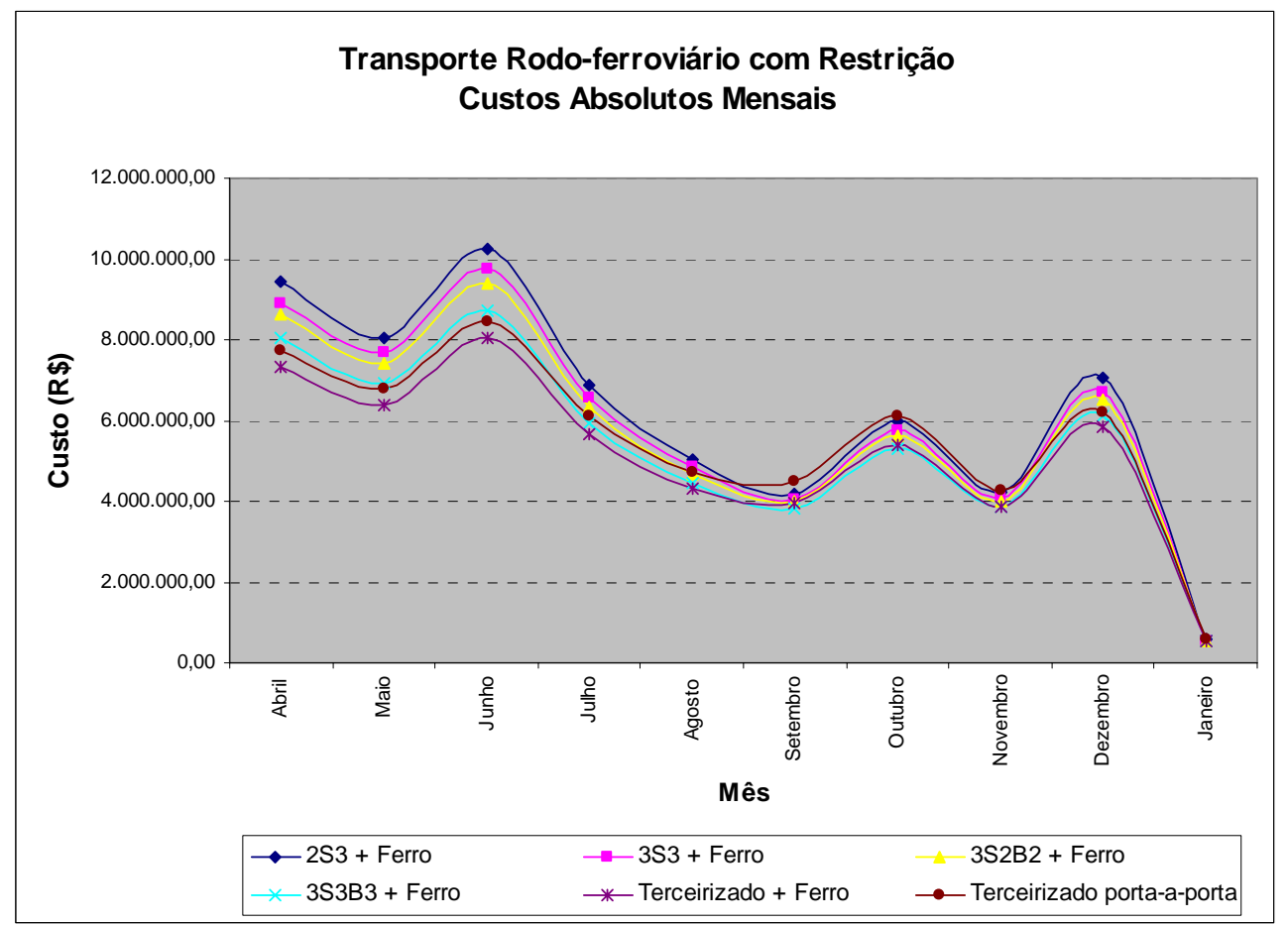

Figura 6.8: Custos absolutos mensais no transporte rodoviário e rodo-ferroviário com restrição de capacidade de embarque de açúcar.

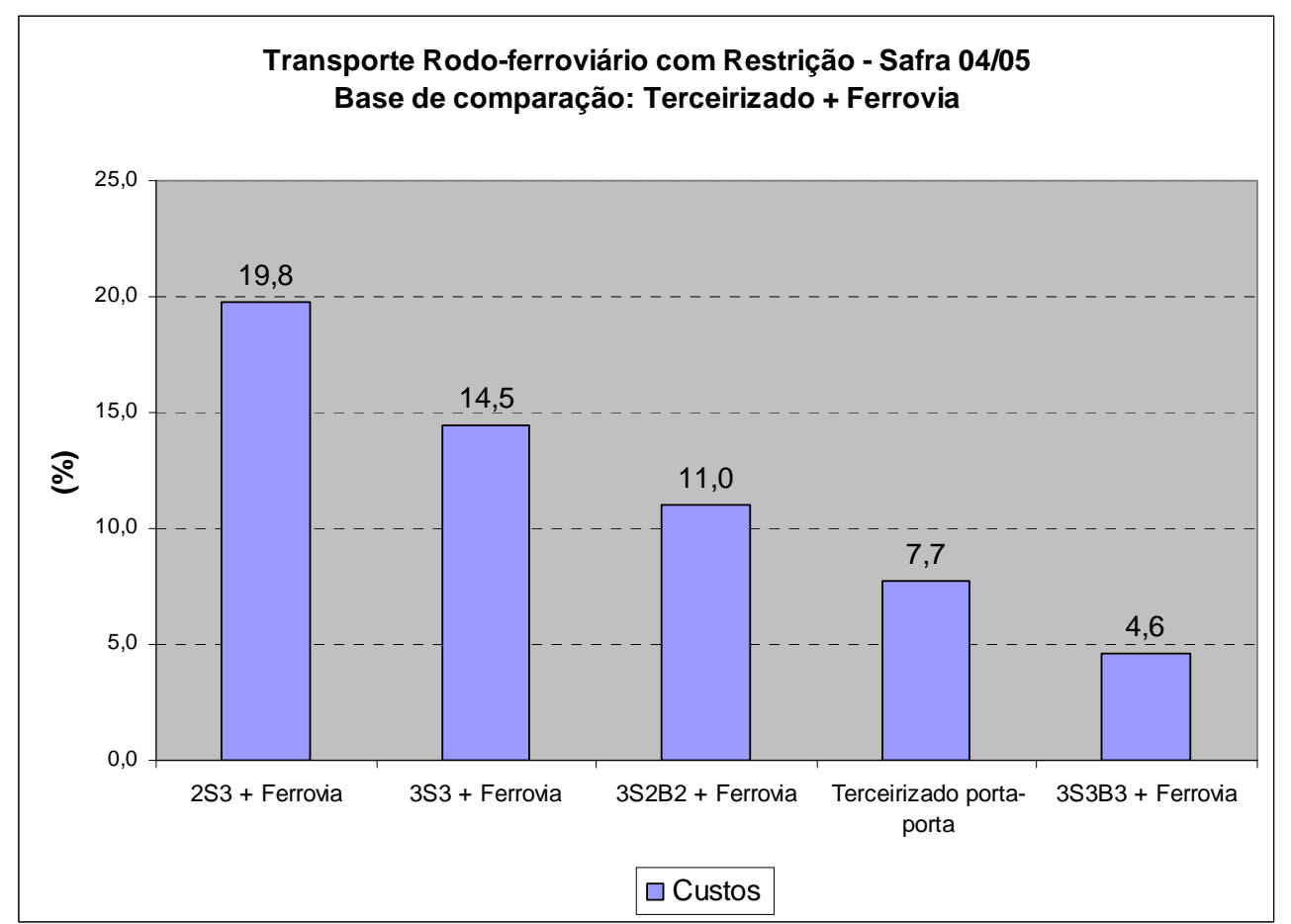

Figura 6.9: Vantagem econômica da operação rodo-ferroviária utilizando frotas terceirizadas nas pontas e nos complementos rodoviários. 
Para ilustrar tal fato toma-se, por exemplo, o mês de maio simulado para a Usina 1, nas alternativas utilizando frota própria 3S3B3 e frota terceirizada, a qual possui demanda por transporte de 28.500 toneladas de açúcar. Nessa situação, 21,10\% do transporte será executado pelo rodoviário porta-a-porta complementar. Assim, em níveis comparativos, a relação de vantagem do frete terceirizado sobre a frota própria 3S3B3 nessa parcela de custos de transporte permanece a mesma (10,2\%). No entanto, para os 78,9\% transportados pelo modo rodo-ferroviário deve-se analisar o custo econômico e o frete por tonelada aplicada às alternativas, como mostra a Figura 6.10. Percebe-se que, no caso deste exemplo, o custo econômico incidente é da ordem de R\$ 2,00 por tonelada e o frete cobrado para o trecho usina-terminal intermodal é da ordem de R\$ 4,00 por tonelada (incremento de 100\%). Embora essa não seja a regra para todas as usinas que utilizam o transporte rodo-ferroviário, na somatória global dos custos do conglomerado, as vantagens relativas das frotas terceirizadas sobre as frotas próprias são reduzidas em função dessa disparidade.

Estrategicamente, portanto, entre as melhores alternativas do transporte rodoviário porta-a-porta e do rodo-ferroviário com restrição de capacidade, é mais interessante economicamente contratar o transporte terceirizado para perfazer as pontas e os complementos rodoviários, em conjunto com a operação ferroviária. No entanto, para participar da fatia de mercado que transporta pela ferrovia, ou diminuir as limitações de capacidade acordadas em contrato, é necessário que os conglomerados deixem de ser exclusivamente usuários do transporte de carga e passem a posição de parceiros das concessionárias na aquisição de vagões, trações e reforma/construção de terminais, por exemplo. Outros fatores que também devem ser analisados são os custos econômicos e os fretes cobrados para perfazer as pontas e os ciclos porta-a-porta rodoviários. Isso porque, eventualmente, os valores dos fretes nas pontas, mesmo sendo praticamente constantes durante a safra, podem inviabilizar economicamente o transporte rodoferroviário utilizando frota terceirizada. 


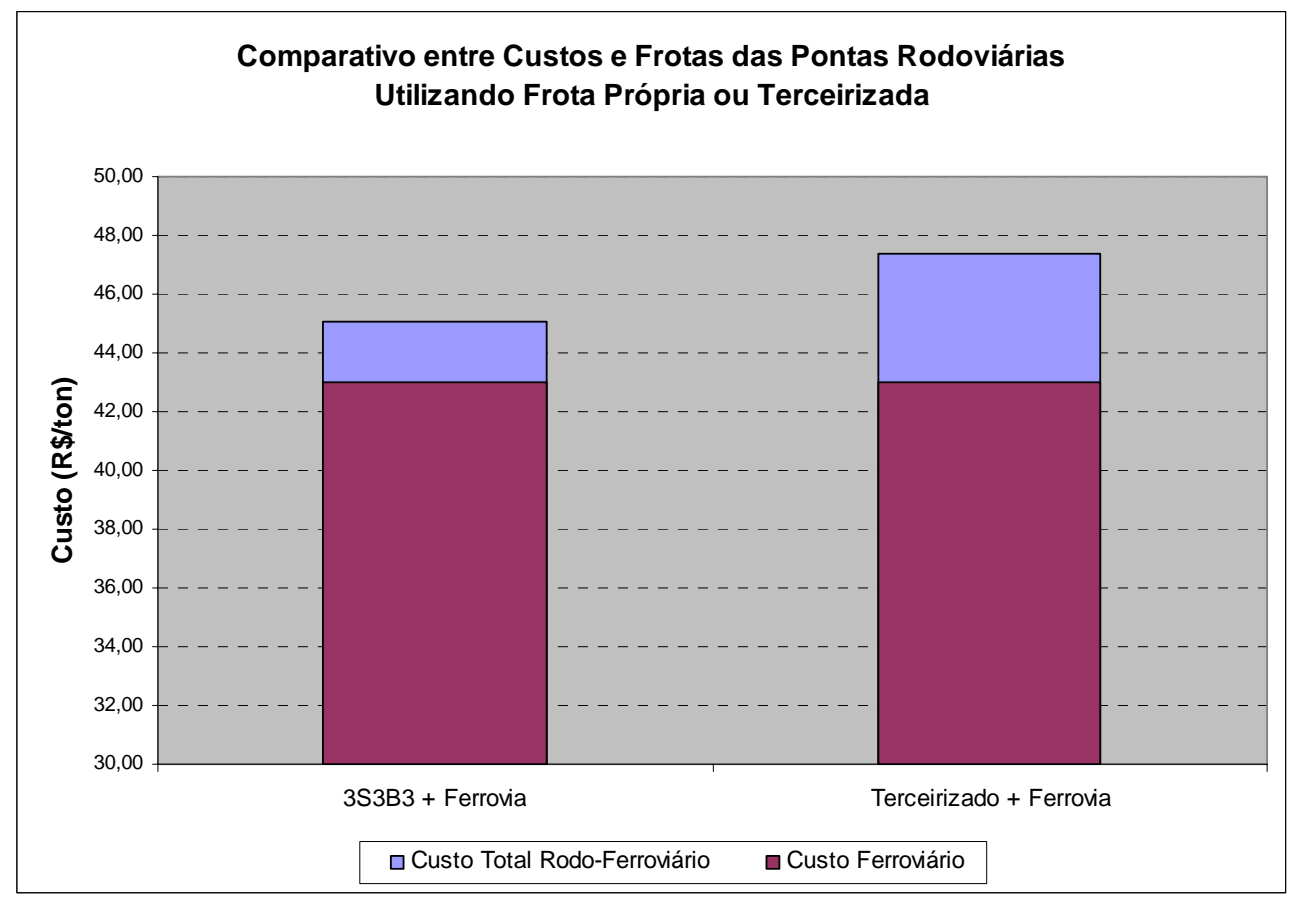

Figura 6.10: Exemplo comparativo de custos e fretes por tonelada referente às pontas rodoviárias.

\subsection{Transporte Rodo-Ferroviário sem Restrição de Capacidade: Análise dos Cenários 5 e 6.}

Dois motivos levam a simulação dos Cenários hipotéticos 5 e 6: o primeiro diz respeito a grande possibilidade de expansão na utilização do modo ferroviário no transporte de açúcar, visto que, segundo informação da trading que forneceu os dados para esse trabalho, apenas 220.000 dos cerca 1.000.000 de toneladas produzidas pelas usinas do conglomerado foram escoadas por este modo na safra 2004/2005, lembrando que na simulação foi considerado a restrição de contrato, o que acumulou em torno de 500.000 toneladas nessa mesma safra.

Em segundo lugar, espera-se que num futuro breve o transporte ferroviário brasileiro possa apresentar melhores condições operacionais a ponto de atender a todos os seus possíveis clientes, e eventualmente, sem restrição na capacidade de transporte. É importante salientar que a atual configuração privatizada do transporte ferroviário brasileiro é relativamente nova (cerca de 10 anos), e somente nos últimos anos as concessionárias passaram a reverter os quadros de sucessivos déficits em suas balanças. 
Considerando que a desregulamentação do setor sucroalcooleiro também tem pouco mais de 10 anos, ambos os setores, em contínua expansão, podem começar desde já a estabelecer metas para que a atual divisão da matriz modal neste mercado tenha uma distribuição mais favorável ao modo rodo-ferroviário.

Nesse sentido, a Figura 6.11 mostra o comportamento dos custos absolutos para cada alternativa dos Cenários 5 e 6. Foi adicionado também a curva de custos da opção rodo-ferroviária com frota terceirizada do Cenário 4 (com restrição de capacidade), pois essa se mostrou a mais competitiva dentre todas as alternativas mostradas até o momento. Nota-se pela análise visual da Figura 6.11 que, comparado com a Figura 6.8, as ordens de grandeza das alternativas rodo-ferroviárias sem restrição de capacidade são menores do que as com restrição de capacidade nos terminais.

No entanto, ao contrário do que aconteceu nos dois grupos de análises anteriores, a alternativa mais vantajosa economicamente na análise global do conglomerado é a que utiliza frota própria tipo 3S3B3 nas pontas rodoviárias. Essa vantagem pode ser percebida mais claramente na Figura 6.12, no comparativo relativo das alternativas analisadas nesses cenários. Isso acontece porque não há parcelas de custos absolutos referentes ao transporte rodoviário porta-a-porta complementar, nos quais as frotas terceirizadas se sobressaem sobre as frotas próprias, e também porque no geral, os fretes nas pontas estão acima dos custos econômicos estimados, o que corresponde à teoria de formação de fretes.

Outro ponto que chama atenção nesses cenários sem restrição de capacidade são as baixas vantagens relativas apresentadas entre as alternativas de transporte. Isso acontece devido ao fato das diferenças existentes entre os custos das pontas rodoviárias serem muito baixas se comparados aos custos despendidos no transporte ferroviário, ou seja, nos Cenários 5 e 6, a parcela mais significativa dos custos absolutos do conglomerado está em função dos fretes ferroviários (transporte e transbordo).

Em termos estratégicos, buscar uma operação sem restrição de capacidade no transporte ferroviário, é a melhor alternativa econômica que um conglomerado pode estabelecer como meta, dentre todas as alternativas apresentadas neste trabalho. No entanto, a opção de investir em frota própria para suprir a ponta rodoviária, como mostraram os resultados, deve ser analisada com cautela, uma vez que as margens de vantagem econômica em relação às alternativas com frota terceirizadas são pequenas 
(1,7\%). Eventualmente, com essa margem de vantagem econômica reduzida, o risco do investimento não compensa os ganhos proporcionados pela alternativa de frota própria, e contratar o transporte terceirizado acaba sendo menos arriscado.

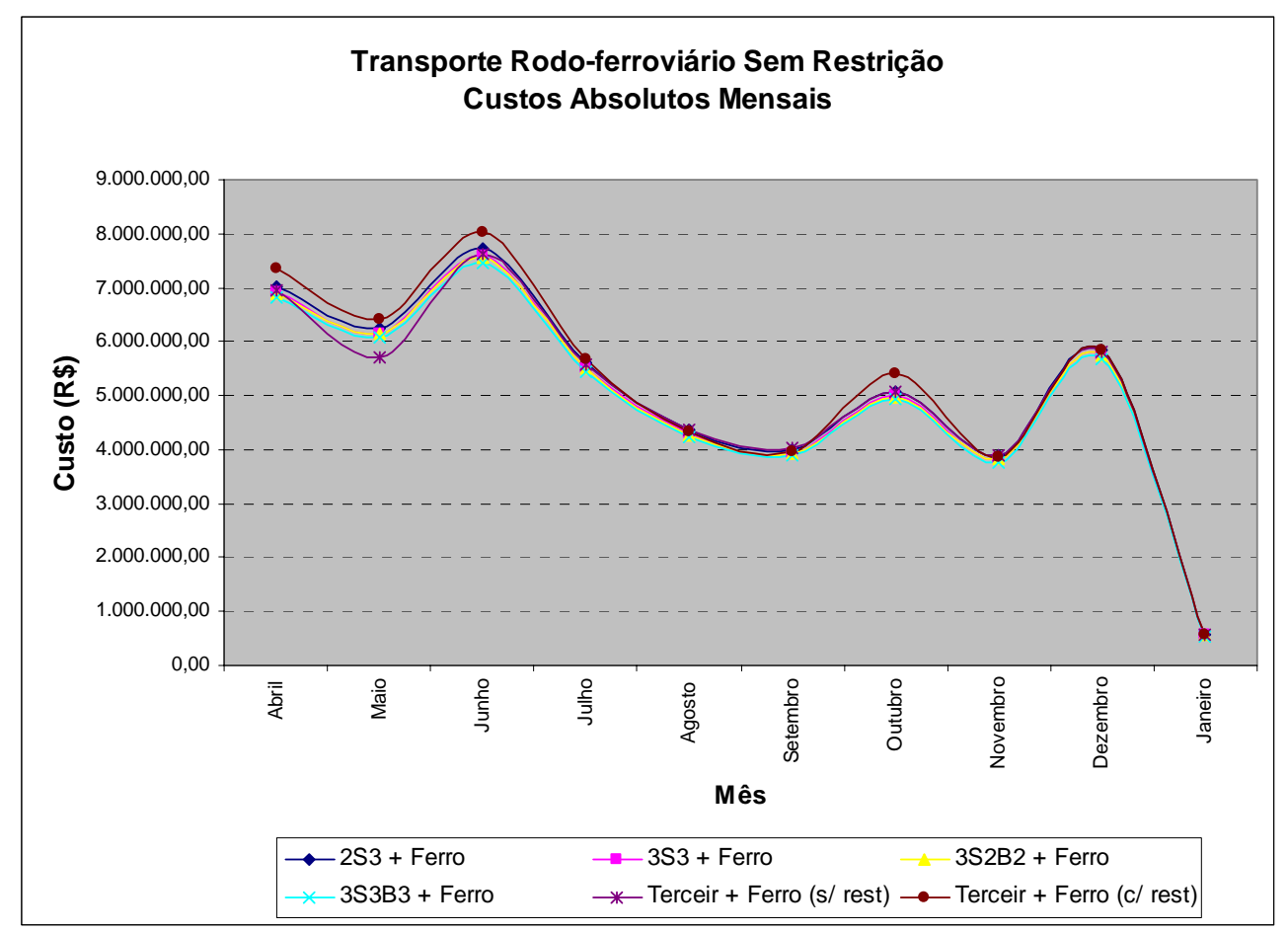

Figura 6.11: Custos absolutos mensais no transporte rodo-ferroviário com e sem restrição de capacidade de embarque de açúcar.

\subsection{Análises de Sensibilidade}

Inicialmente deve-se dizer que as análises de sensibilidade referem-se exclusivamente a simulação dos cenários em suas condições iniciais, ou seja, não será considerada a hipótese de superposição de resultados das análises de sensibilidade, o que geraria múltiplas combinações de resultados. Assim, o objetivo específico da análise de sensibilidade é apresentar a influência isolada de uma variável sobre os custos absolutos de um cenário.

Decorrentes das análises iniciais do capítulo surgem alguns questionamentos os quais serão apresentadas a seguir. 
1.) Por que os custos econômicos para operar frotas próprias apresentados no Cenário 1 são maiores que os custos despendidos com a operação de frota terceirizada apresentado no Cenário 2 ?

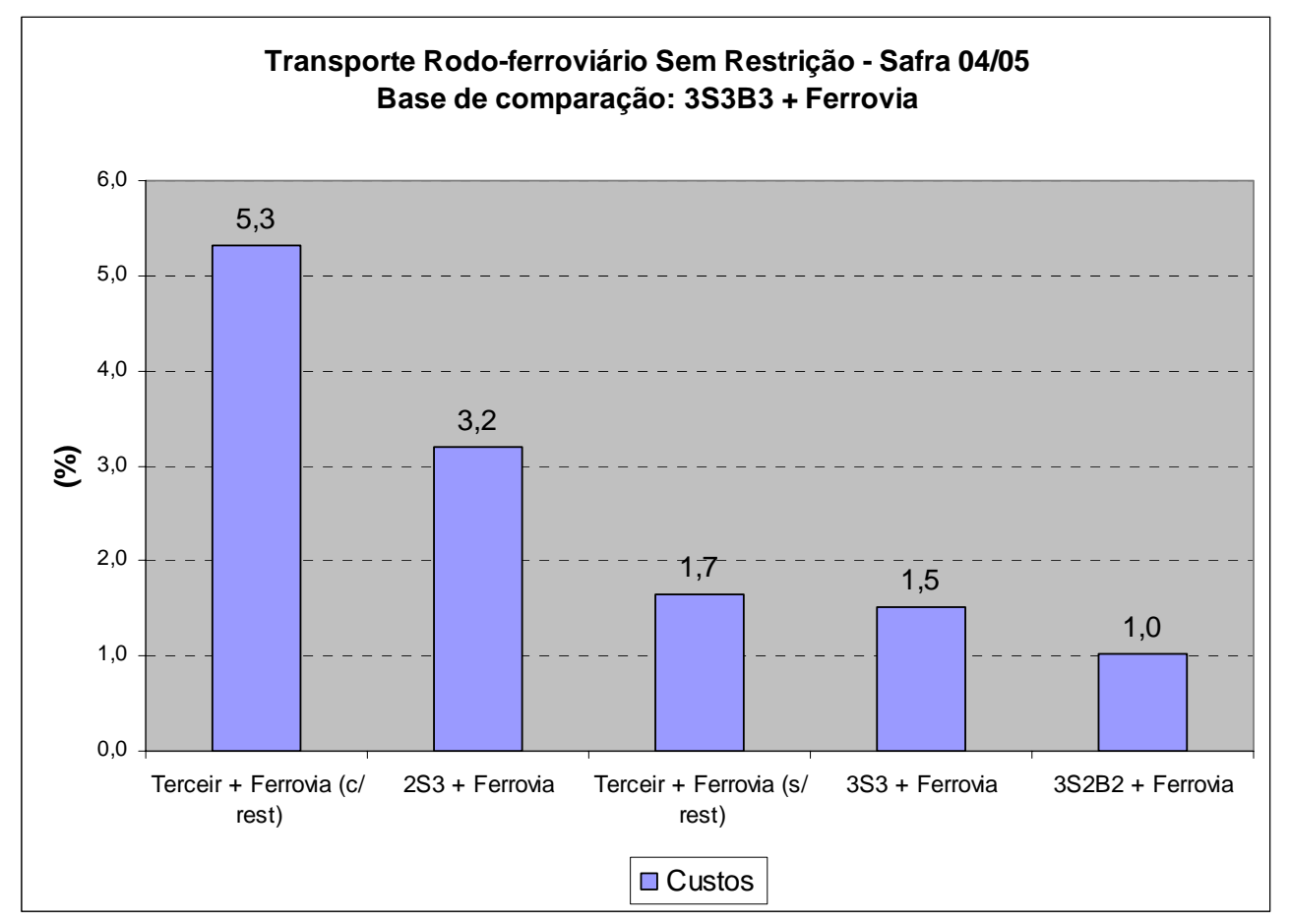

Figura 6.12: Vantagem econômica da operação rodo-ferroviária utilizando frota própria nas pontas rodoviárias.

Para critério de comparação de alternativas tecnológicas semelhantes, serão considerados nas hipóteses a seguir, os custos econômicos para operar frotas próprias constituídas por CVCs tipo 3S3, como as utilizadas pelas frotas terceirizadas.

Primeira hipótese: a incidência de frete de retorno do Porto de Santos para o interior reduz os custos operacionais das empresas de transporte de carga.

Para avaliar essa possibilidade na redução dos custos operacionais das empresas terceirizadas, procedeu-se à análise de sensibilidade para a incidência de fretes de retorno em 20, 35 e 50 \% dos ciclos usina-porto-usina, como mostrado na Figura 6.13.

Pressupõem-se nessas análises que o valor do frete pago para o retorno é equivalente ao custo econômico da volta da combinação no sentido porto-usina, modelado anteriormente. 
Percebe-se pela Figura 6.13 que os custos econômicos de transporte utilizando frota própria se equiparam aos custos com operação terceirizada quando há incidência do frete de retorno da ordem de $40 \%$ do número de viagens necessárias para suprir a demanda por transporte de açúcar do conglomerado.

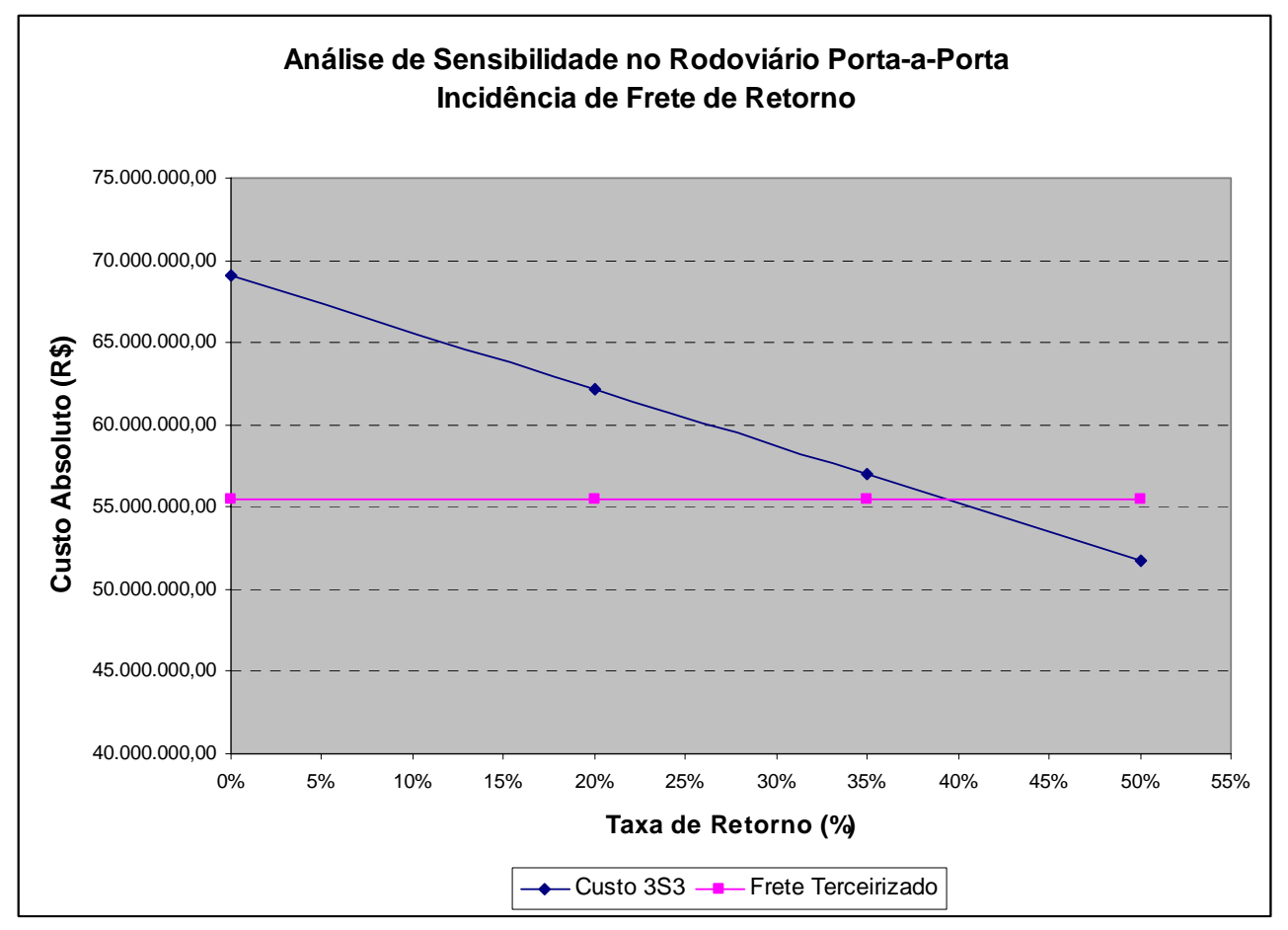

Figura 6.13: Sensibilidade dos custos de operação da frota própria à incidência do frete de retorno.

Segunda hipótese: a produtividade das CVCs são maiores do que as modeladas inicialmente neste trabalho.

Nesse caso, as empresas de transporte de carga conseguem dar maior produtividade durante um mês às CVCs do que o inicialmente modelado neste trabalho. Para isso, é necessário, por exemplo, que as transportadoras mantenham um padrão de operações de transporte sem perdas de tempo em filas no embarque e desembarque nos terminais, sem desligar o veículo (operação tipo hot seat) e que haja uma demanda por transporte contínua e capaz de manter a frota toda ocupada.

Assim, essa análise de sensibilidade avalia o comportamento dos custos absolutos em situações onde a produtividade mensal é da ordem de 25.000, 30.000 e 35.000 quilômetros percorridos nas operações rodoviárias porta-a-porta, como mostrado na Figura 6.14 a seguir. 


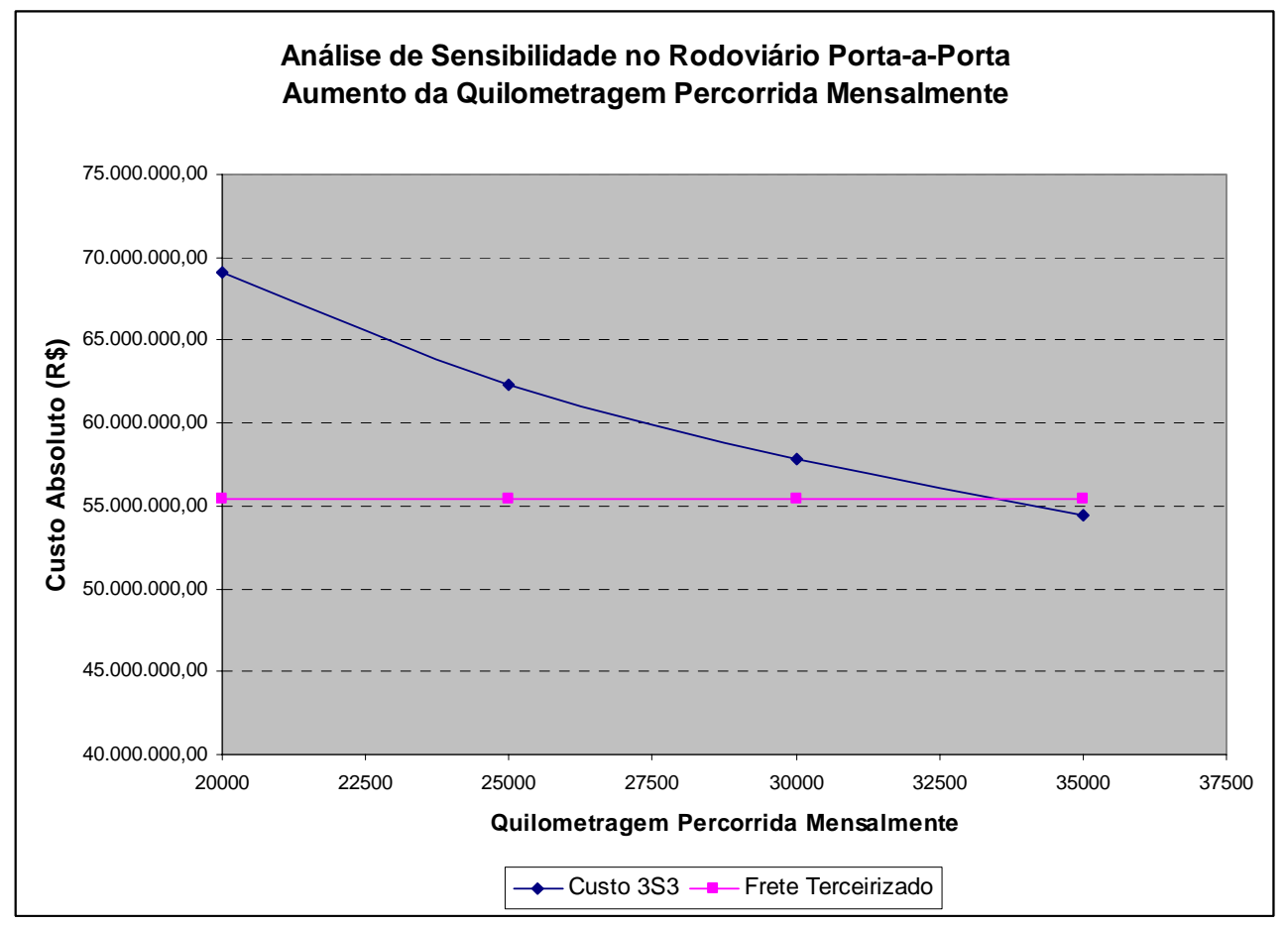

Figura 6.14: Sensibilidade dos custos de operação da frota própria ao aumento da quilometragem percorrida mensalmente.

Percebe-se pelos resultados da análise de sensibilidade que, variando apenas a quilometragem percorrida mensalmente, é necessário que a produtividade alcance grandezas da ordem de 33.000 quilômetros para que os custos econômicos se equiparem aos custos proporcionados pela operação terceirizada, o que sugere um alto nível de serviço durante toda a cadeia de distribuição, além da demanda contínua por transporte de açúcar.

Terceira hipótese: na formação do frete as empresas transportadoras não levam em consideração:

- a remuneração de capital;

- a depreciação das unidades tratora e rebocada;

- seguros e sistemas de monitoramento.

Essa hipótese decorre da idéia de que algumas empresas transportadoras e profissionais autônomos, por desconhecimento ou por pressão dos preços de mercado, atuam com fretes abaixo dos custos econômicos reais. Nesse caso, as parcelas citadas acima não são repassadas para os fretes cobrados aos demandantes por transporte de 
açúcar. Essa atitude é o principal motivo da descapitalização das empresas e autônomos do transporte, que reflete na dificuldade que esses têm para renovar suas frotas.

A Figura 6.15 a seguir mostra a sensibilidade dos custos operacionais das frotas próprias à essas parcelas dos custos fixos. Impressiona o fato de que, mantidas as outras variáveis constantes, é necessário que se subtraiam os custos de remuneração de capital, depreciação da unidade tratora e rebocada, dos seguros também das unidades tratora e rebocada, e do sistema de monitoramento por satélite, para que os custos operacionais das frotas terceirizadas se equivalham aos custos de operação das frotas terceirizadas.

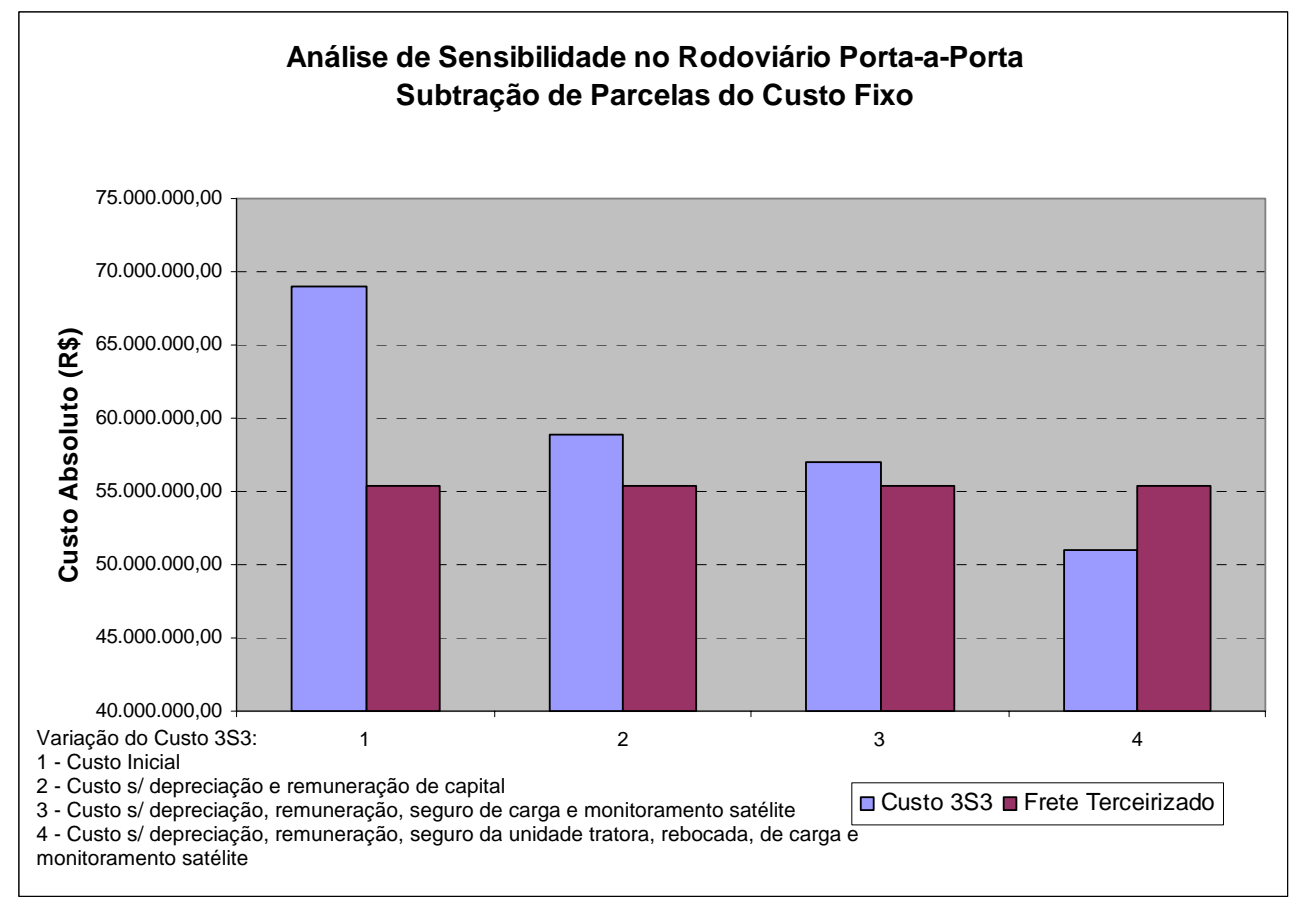

Figura 6.15: Sensibilidade dos custos de operação da frota própria à subtração de parcelas do custo fixo.

É razoável pensar que combinações das análises de sensibilidade mostradas amenizariam a impressão de que os custos operacionais das frotas terceirizadas são muito mais baixos do que os custos operacionais de uma frota própria utilizando a mesma tecnologia. Mesmo assim, fica claro que, se os transportadores não operarem com altos índices de produtividade e taxa de retorno em suas CVCs, os empresários e autônomos encontrar-se-ão em situação defasada do ideal econômico para o seguimento, o que requer intervenções urgentes do poder público, associações da classe e sociedade. 
2.) De que forma a operação com frota própria utilizando a CVC 3S3B3, a qual é a mais competitiva do Cenário 1, se torna viável economicamente no transporte rodoviário porta-a-porta frente a alternativa com frota terceirizada?

Primeira hipótese: disponibilizar a frota própria para efetuar fretes de retorno provenientes do Porto de Santos com destino ao interior.

Análogo a análise de sensibilidade desenvolvida na resposta 1, a Figura 6.16 mostra a sensibilidade da frota própria com 3S3B3 à incidência de fretes de retorno, da ordem de 20, 35 e 50\% do total de viagens necessárias para suprir a demanda por transporte de açúcar do conglomerado de usinas.

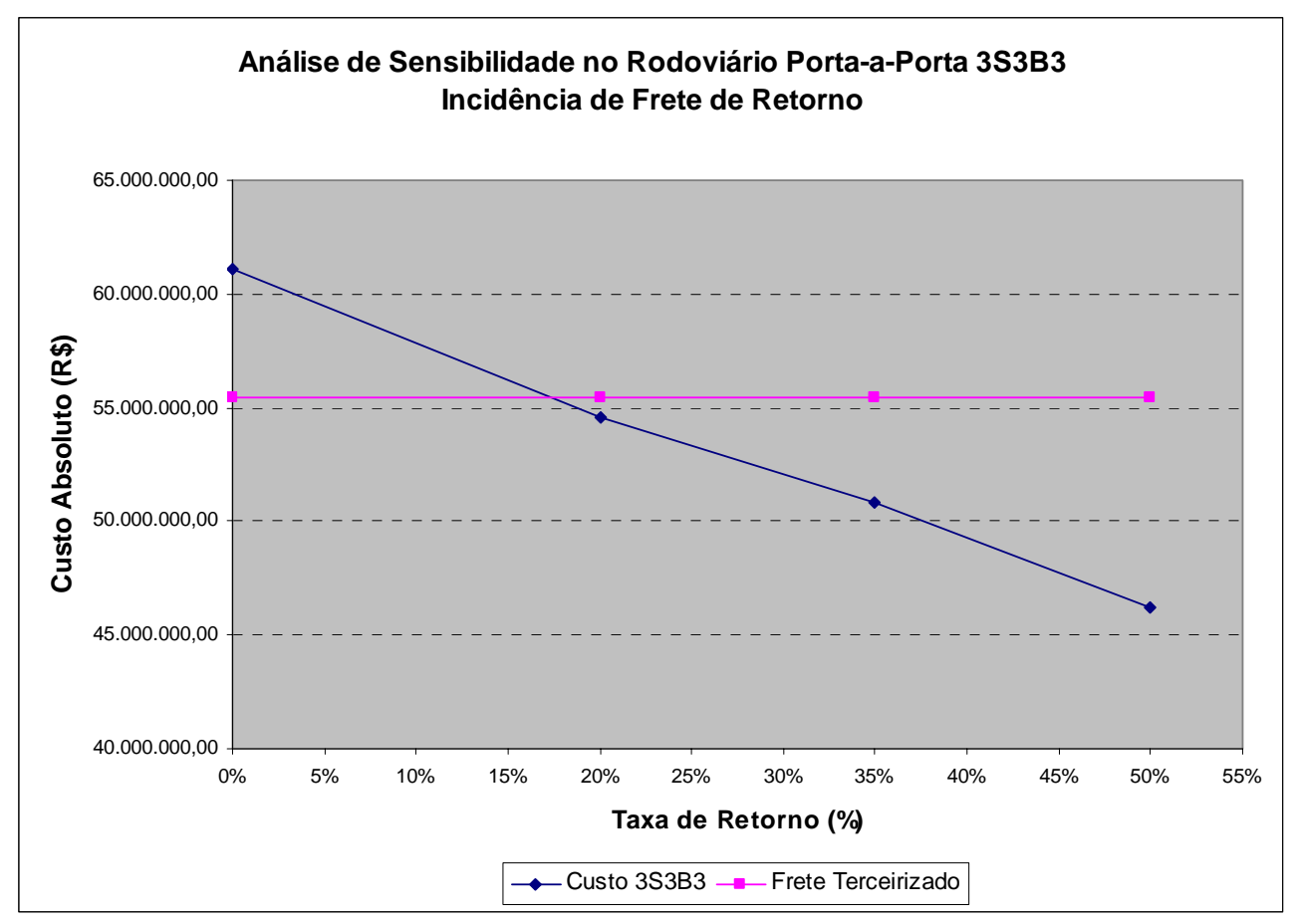

Figura 6.16: Sensibilidade dos custos de operação da frota própria 3S3B3 à incidência do frete de retorno.

Percebe-se pela análise da Figura 6.16 que a incidência de taxa de retorno da ordem de $17,5 \%$ é suficiente para que os custos operacionais do 3S3B3 sejam equivalentes aos custos das frotas terceirizadas que utilizam o 3S3. Incidências de retorno da ordem de 35 e 50\% dão aos custos das frotas próprias, por exemplo, vantagens sobre as frotas terceirizadas de cerca de 8 e $20 \%$ respectivamente. 
Segunda hipótese: a produtividade mensal do 3S3B3 deve ser superior aos 20.000 quilômetros adotados pelo modelo de custos operacionais.

Eventualmente, a produtividade das CVCs 3S3B3 podem alcançar ordens de grandeza superiores ao que foi adotado inicialmente pelo modelo de custos operacionais rodoviários (20.000 quilômetros). Assim, é relevante avaliar a competitividade dos custos da frota própria utilizando 3S3B3 no transporte porta-a-porta para produtividades de 25.000, 30.000 e 35.000 quilômetros mensais.

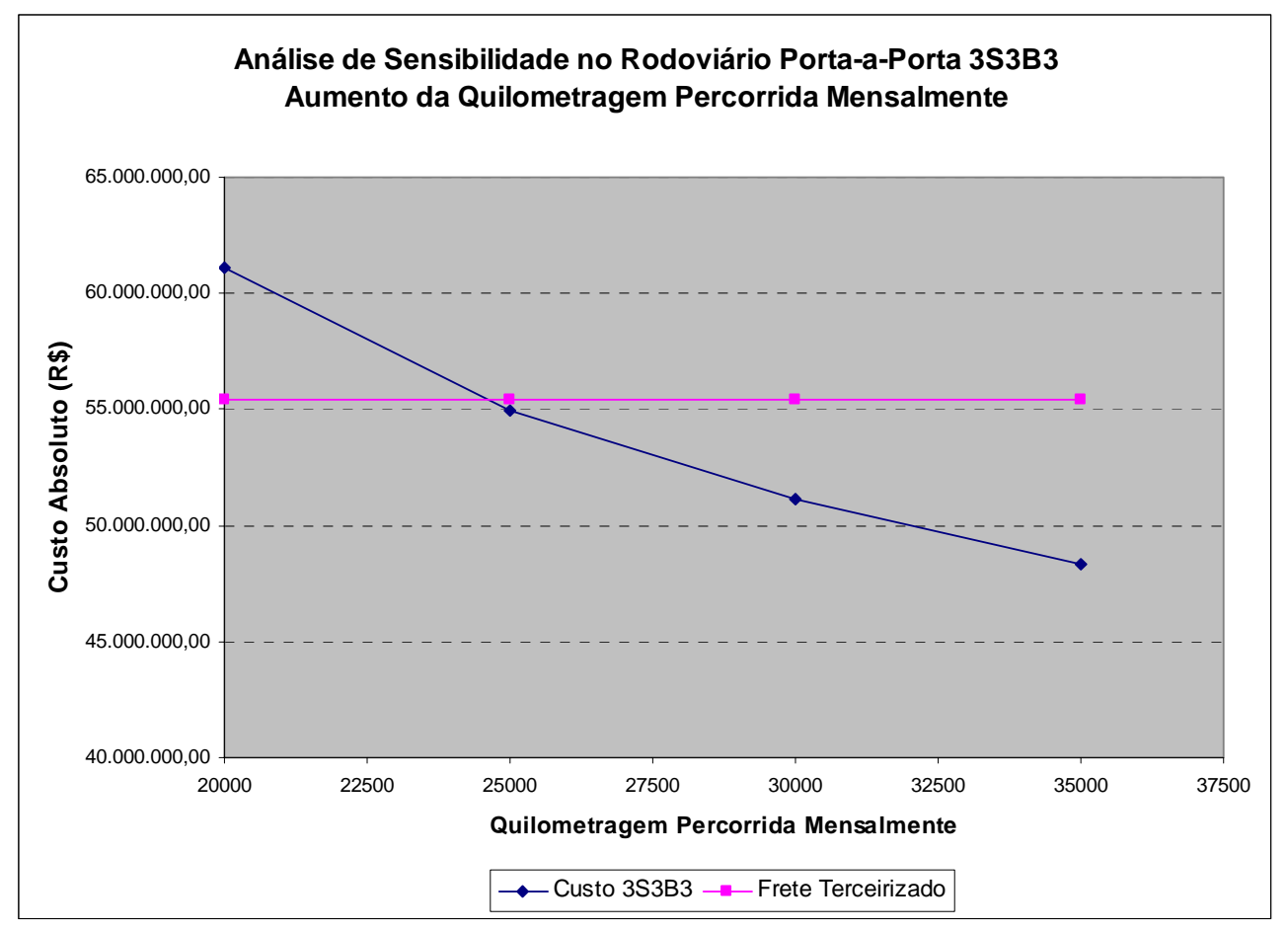

Figura 6.17: Sensibilidade dos custos de operação da frota própria 3S3B3 ao aumento da quilometragem percorrida mensalmente.

Pela inspeção da Figura 6.17 percebe-se que para produtividades de 24.000 quilômetros mensais aproximadamente, os custos operacionais do 3S3B3 já são equivalentes aos custos das frotas terceirizadas. Se os incrementos das produtividades alcançarem 30.000 ou 35.000 quilômetros mensais, as vantagens econômicas da frota própria chegam a 8 ou 15\% sobre os custos das frotas terceirizadas, respectivamente.

Por fim, conclui-se que para a operação de frota própria do 3S3B3 ser competitiva à alternativa de frota terceirizada, não são necessários grandes incrementos nas situações previstas inicialmente pelo modelo deste trabalho. No entanto, para que tais situações sejam possíveis de serem realizadas, é necessário que a legislação permita a 
utilização dessas tecnologias, a infra-estrutura seja compatível nas vias e terminais intermodais, e que a operação tenha bons níveis de eficiência. 


\section{CONCLUSÕES E RECOMENDAÇÕES}

\subsection{Conclusões}

Este trabalho teve por o objetivo principal investigar as principais alternativas de transporte existentes para o açúcar a granel de exportação e propor estratégias que orientem os demandantes por transporte de carga deste mercado a racionalizar seus custos de distribuição.

Dessa forma, pôde-se ao final constatar em termos econômicos, que as novas tecnologias rodoviárias 3S2B2 e 3S3B3 são mais vantajosas do que os 3S3 e 2S3 amplamente utilizados nesse mercado, como já era de se esperar. A contribuição importante neste caso foi o estabelecimento das ordens de grandeza das vantagens relativas entre as alternativas, onde as CVCs tipo 3S3B3 têm ganhos econômicos entre $13 \%$ e $20 \%$, e de capacidade de transporte entre $50 \%$ e $66,7 \%$ a mais do que as alternativas $3 \mathrm{~S} 3$ e 2S3. As CVCs tipo 3S2B2 por sua vez tem ganhos econômicos entre $3,5 \%$ e $10 \%$, e capacidades de transporte de $23,3 \%$ a $37 \%$ a mais do que os mesmos $3 \mathrm{~S} 3$ e $2 \mathrm{~S} 3$.

No entanto, nenhuma das novas tecnologias apresentou-se mais competitiva em termos de custos econômicos nas operações de frotas próprias do que as operações com frotas terceirizadas, ambas no porta-a-porta. Mesmo assim, estrategicamente é interessante para os demandantes por transporte estimularem seus parceiros, ou proporem parcerias com os mesmos, a adquirir essas novas tecnologias, com o objetivo de baixar os custos econômicos das frotas terceirizadas, e conseqüentemente, o repasse desses custos para os usuários do transporte de carga.

A análise de sensibilidade feita ao final do capítulo de análises de resultados mostrou que para oferecerem fretes tão inferiores em relação aos custos econômicos das frotas próprias de mesma tecnologia, as empresas de transporte de carga devem operar com níveis elevados de produtividade (33.000 quilômetros por mês) de suas CVCs ou taxas significativas de fretes de retorno (40\%), as quais reduzem proporcionalmente seus custos fixos por quilômetro percorrido. 
Já para os 3S3B3 tornarem-se competitivos frente à operação terceirizada, são necessários incrementos relativamente menores do que os dos 3S3. Nesse caso, a incidência de fretes de retorno de 17,5\% ou produtividades de 24.000 quilômetros mensais são suficientes para a equiparação entre custos econômicos e fretes, o que também não dispensa cuidados especiais de operação, infra-estrutura adequada e fornecimento contínuo de produto pelo conglomerado.

Outro ponto relevante que teve sua sensibilidade analisada diz respeito a algumas parcelas do custo fixo relativos ao transporte terceirizado. O que acontece é que os transportadores podem estar formando seus valores de frete sem considerar algumas parcelas do custo fixo, como remuneração de capital, depreciações das unidades tratoras e rebocadas, alguns seguros não obrigatórios e sistemas de monitoramento por satélite, por exemplo. Constatou-se que, mantidas fixas todas as outras variáveis, somente quando todas essas parcelas de custo fixo mencionadas são subtraídas há equiparação entre custos e fretes para mesmas tecnologias.

Essa atitude é preocupante, e já foi abordada em outros trabalhos como Danilevicz et al. (2003) e Moreira e Ratton Neto (2003), pois a descapitalização desse mercado reflete no envelhecimento da frota nacional, além de socialmente causar a marginalização da classe transportadora. Por isso, nesse momento de introdução de novas CVCs no mercado, deve ser discutida a regulamentação do setor de transporte de carga rodoviária para que a própria classe transportadora não seja prejudicada.

É importante ressaltar que, eventualmente, a disparidade entre custos e fretes possa ser justificada também pela combinação desses fatores que tiveram suas sensibilidades analisadas (produtividade, taxa de retorno e parcelas do custo fixo), as quais não foram consideradas neste trabalho.

Quando as análises se estendem ao modo rodo-ferroviário, percebeu-se que este é mais atraente do que o rodoviário porta-a-porta para o mercado de exportação de açúcar, mesmo quando a operação tem restrições de capacidade.

Nos cenários em que ocorrem restrições de capacidade no transporte ferroviário, utilizar frota terceirizada para executar as pontas e o complemento rodoviário mostrouse a melhor alternativa dentre todas as outras. No entanto, atenta-se para o fato de que, nas pontas de acesso à ferrovia, algumas usinas pagam valores de frete por tonelada 
quilômetro superiores ao que pagam para o transporte direto ao Porto de Santos. Os demandantes por transporte devem, portanto, verificar este parâmetro quando no fechamento de contratos com os transportadores.

No transporte rodo-ferroviário sem restrição de capacidade, podem ser obtidos ganhos expressivos em relação ao transporte rodo-ferroviário com restrição, o que também já era esperado. No entanto, ao contrário das duas outras análises, verificou-se que para as pontas rodoviárias, a operação de frota própria com a CVC tipo 3S3B3 é, neste caso a mais atraente economicamente dentre todas as outras apresentadas na investigação. Mesmo assim, a adoção dessa prática pode ser arriscada, pois as margens de vantagens econômicas são relativamente pequenas frente à ponta terceirizada (1,7\%), e eventualmente não justificam o risco do investimento.

Mas, estrategicamente para o mercado de açúcar, buscar restrições de capacidades ferroviárias cada vez menores parece o objetivo final a ser alcançado. Para tal, os conglomerados precisam aumentar seus poderes de negociação frente às concessionárias e usuários concorrentes, propondo parcerias na aquisição de material rodante, adequação/construção de terminais e armazéns, em troca de participações maiores no transporte ferroviário.

\subsection{Recomendações}

Para trabalhos futuros e complementares a esse, recomenda-se que seja investigada com maior profundidade a formação dos fretes rodoviários praticados pelas empresas de transporte de carga, já que os resultados das simulações executadas mostraram que na maior parte dos cenários, o valor pago pelo frete aparentemente não cobre os custos econômicos reais dos transportadores.

Em outras simulações pode-se considerar nos modelos de custos rodoviários as alterações de custos variáveis como preços de combustíveis, lubrificantes, pneus, serviços, entre outros, nas planilhas eletrônicas de modelagem mensal. Ao contrário do modelo adotado com valores médios anuais, essas variações poderiam apresentar novos resultados para as operações com frota própria. 
Eventualmente, utilizando os modelos construídos, podem-se analisar os resultados sob o ponto de vista de uma usina em particular. Salientou-se sempre nas análises, que os resultados apresentados referem-se aos custos do conglomerado. Assim, é possível que numa análise individual a estratégia adotada possa ser diferente da adotada pelo conglomerado.

Recomenda-se também que um modelo de custos ferroviário seja desenvolvido, mesmo sabendo-se da grande dificuldade de fazê-lo. Esse trabalho é importante para que os usuários e a sociedade como um todo tenham uma visão mais clara sobre as bases em que os fretes ferroviários são estabelecidos, visto que nem mesmo a legislação do setor prevê um modelo como este e é possível que os fretes não correspondam a uma realidade econômica da operação. A partir dessa modelagem, poder-se-ia aproveitar melhor a potencialidade de ferramentas de modelagem de rede, como a utilizada neste trabalho, para estimar custos econômicos de transporte envolvendo modos de transportes diferentes e complementares.

Por fim, no setor sucroalcooleiro, sugere-se uma investigação do custo-benefício de se prover investimentos na implantação/adequação de terminais intermodais, armazéns, vias permanentes e na aquisição de material rodante, para viabilizar a alternativa rodo-ferroviária sem restrição de capacidade. 


\section{REFERÊNCIAS BIBLIOGRÁFICAS}

ABCR (2004). Associação Brasileira das Concesionárias Rodoviárias. Disponível em: $<$ http://www.abcr.org.br>. Acesso em 20 jun. 2004.

AMORIM, M.D; SILVA, L.F.C.F.; STRAUCH, J.M. (2001). Sistema de Apoio Rodoviário: Uma Abordagem Metodológica. Disponível em: $<$ http://www.ic.unicamp.br/ cmbm/geoinfo/papers/141marceloamorim.pdf $>$. Acesso em 31 jan. 2005.

ARTESP (2004). Agência Reguladora dos Transportes do Estado de São Paulo. Disponível em: <http://www.artesp.sp.gov.br>. Acesso em: 20 jun. 2004.

BAMFORD, C.G. (2001). Transport Economics, 2. ed., Ed. Heinemann. Oxford.

BANCO CENTRAL DO BRASIL (2004). Balança Comercial 2003. Disponível em: <http://www.bcb.gov.br>. Acesso em: 14 jan. 2005.

BAZARAA, M.S.; JARVIS, J.J.; SHERALI, H.D. (1990). Linear Programming and Network Flows. 2.ed. New York, Chichester, Brisbane, Toronto, Singapore. John Wiley \& Sons.

BEGHINI, P.P. (2002). Estudo Logístico do Uso Consorciado de Incineradores para Resíduos de Serviços de Saúde. Dissertação (Mestrado) - Escola de Engenharia de São Carlos, Universidade de São Paulo, São Carlos-SP. 2002.

BELIK, W.; RAMOS, P.; VIAN, C.E.F. (1998). Mudanças Institucionais e Seus Impactos Nas Estratégias dos Capitais do Complexo Agroindustrial Canavieiro no Centro-Sul do Brasil. Assunto: Economia Agrícola. Poços de Caldas-MG. Anais do XXXVI Encontro Nacional do Saber.

BEUTHE, M.; DEGRANDSART, F.; GEERTS, J.F.; JOURQUIN, B. (2002). External Costs of The Belgian Interurban Freight Traffic: A Network Analysis of their Internalisation. Tranportation Research, part D, vol. 7, pp. 285-301.

BOOKBINDER, J.; FOX, N.S. (1998). Intermodal Routing of Canada - Mexico Shipments under NAFTA. Transportation Research, part E, vol. 34, n. 4, pp. 289-303. 
BRASIL (1995). Lei no 8.987, de 13 Fevereiro de 1995. Dispõe sobre o regime de concessão e permissão da prestação de serviços públicos previsto no art. 175 da Constituição Federal, e dá outras providëncias.

BRASIL (1999a). Lei n ${ }^{\circ}$ 9.503, de 23 de Setembro de 1998. Institui o código de trânsito brasileiro. Lex: Nova Coletânea de Legislação de Trânsito, Porto Alegre-RS, $16^{a}$ ed., p. 9-90.

BRASIL (1999b). Resolução ${ }^{0} 12$ de 06 de Fevereiro de 1998. Estabelece os limites de pesos e dimensões para veículos que transitem por vias terrestres. Conselho Nacional de Trânsito. Lex: Nova Coletânea de Legislação de Trânsito, Porto Alegre-RS, $16^{a}$ ed., p. 437-38.

BRASIL (1999c). Resolução no 68 de 23 de Setembro de 1998. Requisitos de segurança necessários à circulação de combinação de veículos de carga - CVC, a que se refere os arts. 97, 99 e 314 do Código de Trânsito Brasileiro - CTB e os $\S 3^{\circ}$ e $4^{\circ}$ dos arts. $1^{\circ}$ e $2^{\circ}$, respectivamente, da Resolução 12/98 - CONTRAN. Conselho Nacional de Trânsito. Lex: Nova Coletânea de Legislação de Trânsito, Porto Alegre-RS, 16a ed., p. 500-03.

BRASIL (2004). Resolução $n^{0}$ 164, de 10 de Setembro de 2004. Acresce parágrafo único ao art. $1^{\circ}$ da Resolução do CONTRAN n ${ }^{\circ}$ 68/98. Estabelece a suspensão de AETs para veículos com PBTC superior a 45 toneladas e até 57 toneladas. Disponível em: <http://www.mj.gov.br/consultafacil/>. Acesso em: 10 jan. 2005.

CAIXETA-FILHO, J.V.; GAMEIRO, A.H. (2001). Transporte e Logística em Sistemas Agroindustriais. São Paulo-SP, Atlas.

CALIPER (1996a). TransCAD Transportation GIS Software. User’s Guide Version 3.0 for Windows. Caliper Corporation, Newton, EUA.

CALIPER (1996b). TransCAD Transportation GIS Software. Routing and Logistics with TransCAD 3.0. Caliper Corporation, Newton, EUA.

CASTRO, N. (2002). Estrutura, Desempenho e Perspectivas do Transporte Ferroviário de Cargas. Núcleo de Estudos e Modelos Espaciais Sistêmicos - NEMESIS. Disponível em: <http://www.nemesis.org.br>. Acesso em: 24 jan. 2005.

CASTRO, N.; CARDOSO, L.C.; ESPOSITO, J.R. (1997). Definição e Implementação dos Novos Marcos Regulatórios nas Áreas de Infra-Estrutura - Setor Ferroviário. 
Núcleo de Estudos e Modelos Espaciais Sistêmicos - NEMESIS. Disponível em: $<$ http://www.nemesis.org.br>. Acesso em: 24 jan. 2005.

CASTRO, N.; LAMY, P. (1994). A Reforma e a Mordenização do Setor de Transporte Ferroviário de Carga. Ipea, Rio de Janeiro-RJ.

CLARKE, R.M. (1999). Motor Vehicle Size and Weight Considerations. A1B04: Committee on Motor Vehicle Size and Weight. Transportation Research Board.

CNT (2002). Pesquisa Ferroviária. Relatório Analítico - Confederação Nacional do Transporte. Brasília-DF.

COLLISCHONN, J.; PILAR, V. (1999). Caminhos de Mínimo Custo no Projeto de Canais de Irrigação. In: Congresso Brasileiro de Engenharia Agrícola, Pelotas-RS, 1999. Anais.

CORTRIGHT, J. (2001). Transportation, Industrial Location and the New Economy: How Will Changes in Information Technology Change the Demand for Freight Transportation and Industrial Location? Impresa Inc. Artigo preparado para a Roundtable E-Freight, Portland, Oregon, USA.

CRAINIC, T.G.; LAPORTE, G. (1997). Planning Models for Freight Transportation. European Journal of Operation Research, v. 97 (3), pp. 409-38.

DANILEVICZ, A.M.F.; GIUSTINA, C.D.; ARAÚJO, R.R. (2003). Uma Análise Exploratória dos Problemas Associados ao Transporte Rodoviário de Carga por Autônomos. In: XVII ANPET. Congresso Nacional de Ensino e Pesquisa em Transportes, Rio de Janeiro -RJ, 2003. Anais, v. 2, p. 1203-15.

DAVIS JR., C.A. (2000). Aumentando a Eficiência da Solução de Problemas de Caminho Mínimo em SIG. Empresa de Informática e Informação de Belo Horizonte S.A. - PRODABEL.

DEMARCHI, S.H. (1995). Influência dos Veículos Pesados na Capacidade de Interseções Rodoviárias. Dissertação (Mestrado) - Escola de Engenharia de São Carlos, Universidade de São Paulo. São Carlos-SP.

DER-SP (2001). Análise das Conseqüências do Tráfego de CVCs (Combinações de Veículos de Carga) sobre as Obras de Arte Especiais da Rede Viária do DER-SP. Relatório Técnico, contrato DER11.118-0. 
DOT (1995a). U.S. Department of Transportation. Roadway Geometry and Truck Size and Weight Regulations: Comprehensive Truck Size and Weight Study, Phase I Synthesis: Working Paper 5. FHWA, fev.

DOT (1995b). U.S. Department of Transportation. Traffic Operations and Truck Size and Weight Regulations: Comprehensive Truck Size and Weight Study, Phase I Synthesis: Working Paper 6. FHWA, fev.

DOT (2000). Department of Transportation. Comprehensive Truck Size and Weight Study. Ago.

EVERS, P.T.; HARPER, D.V.; NEEDHAM, P.M. (1996). The Determinants of Shippers Perceptions of Modes. Transportation Journal, v. 36, pp. 13-25.

FILGUEIRAS, J.; WIDMER, J.A.; SOBRADO, V.T. (2004). Departamento Nacional de Trânsito - DENATRAN. Grupo Técnico de Pesos, Dimensões e Combinações de Veículos. Relatório Técnico.

FLEURY, P.F.; WENKE, P.; FIGUEIREDO, K.F. (2000). Logística Empresarial: A Perspectiva Brasileira. Ed. Atlas, São Paulo-SP.

FORD, L.R.; FULKERSON, D.R. (1962). Flows in Transportation Networks. New Jersey, Princeton University Press.GAZETA MERCANTIL (2004). ANTT Propõe Novo Acesso a Santos. Gazeta Mercantil. São Paulo, 29 set. 2004.

HILLIER, F.S.; LIEBERMAN, J. (1988). Introdução à Pesquisa Operacional. 3.ed. (1.ed. em português). São Paulo-SP. Universidade de São Paulo.

HITCHCOCK, F.L. (1941). Distribution of a Product from Several Sources to Numerons Localities, Journal of Math. Physics, vol. 20.

HORNER, M.W.; O’KELLY, M.E. (2001). Embendding Economies of Scale Concepts for Hub Network Design. Journal of Transport Geography, vol. 9, pp. 255-65.

INSTITUTO BRASILEIRO DE GEOGRAFIA E ESTATÍSTICA (IBGE). Disponível em : <http://www.ibge.gov.br/>. Acesso em: 30 ago. 2004.

INSTITUTO DE ECONOMIA AGRÍCOLA DO ESTADO DE SÃO PAULO (IEA). Disponível em: <http://www.iea.sp.gov.br>. Acesso em : 29 ago. 2004. 
KALSAAS, T. (1999). An Analysis of the Location of a Freight Terminal with GIS-T Based Methods. Disponível em: <http://stratema.sigis.net/cupum/pdf/G8.pdf > . Acesso em: 31 jan. 2005.

KANAFANI, A. (1983). Transportation Demand Analysis. New York, St. Louis, San Francisco, Auckland, Bogotá, Hamburg, Johannesburg, London, Madrid, Mexico, Montreal, New Delhi, Panama, Paris, São Paulo, Singapore, Sydney, Tokyo, Toronto. McGraw-Hill.

KAWAMOTO, E. (1999). Análise de Sistemas de Transporte. Escola de Engenharia de São Carlos-USP. 2.ed. rev. e aum. São Carlos-SP. (reimpressão).

KHAN, A.M.; ARMSTRONG, J.M. (2001). Role os GIS in Improving the Flexibility and Reliability of Urban Transportation Planning and Management. Disponível em: <http://www.geog.umd.edu/gis/literature/conferences/CUPUM01/Papers/A_158.PDF>. Acesso em: 31 jan. 2005.

KOOPMANS, T.C. (1949). Optimum Utilization of the Transportation System, Econometrica, vol. 17, Supl.

KRAPFEL, R.E.; MENTZER, J.T. (1982). Shippers’ Transportation Choice Processes Under Deregulation. Industrial Marketing Management, vol. 11, pp. 117-24.

KRÜGER, M.A. (2003). Sistemática de Avaliação da Viabilidade de Empresas de Transporte Ferroviário de Cargas. Dissertação (Mestrado) - Universidade Federal de Santa Catarina. Florianópolis-SC.

LAMBERT, D. M.; STOCK, J.R.; VANTINE, E.J.G. (1998). Administração Estratégica da Logística. São Paulo: Vantine Consultoria.

LAITILA, T.; WESTIN, K. (2001). The Eco Factor in Freight Transportation Demand. Transportation Reseach Unit, Department of Statistics, Department of Social and Economic Geography. University of Umea, Umea, Sweden.

LEWIS, S. (1990). Use of Geographical Information Systems in Transportation Modeling. ITE Journal, p.34-38, mar.

LIMA, R.S. (2003). Bases para uma Metodologia de Apoio à Decisão para Serviços de Educação e Saúde sob a Ótica dos Transportes. Tese (Doutorado). - Escola de Engenharia de São Carlos, Universidade de São Paulo, São Carlos-SP. 2003. 
LOTTI, C.P. (2002). Método de Sistematização e Levantamento de Dados para o Estudo da Relação de Acidentes com o Alinhamento em Planta e Perfil de uma Rodovia. Tese (Doutorado). - Escola de Engenharia de São Carlos, Universidade de São Paulo, São Carlos-SP. 2002.

MACHADO NETO, E.F.; SETTI, J.R. (1994). Um Modelo de Ultrapassagem em Rodovias de Pista Simples e Dupla Mão de Direção. In: VII ANPET. Congresso de Pesquisa e Ensino em Transportes, Anais. Recife-PE, p. 258-68.

MARÍN, A.; PELEGRÍN, B. (1996). A Branch and Bound Algorithm for the Transportation Problem with Location of $p$ Transshipment Points. Computers Operations Research, vol. 24, n. 7, pp. 659-78.

MARTINS, R.S.; CAIXETA-FILHO, J.V. (1998). O Desenvolvimento dos Sistemas de Transporte: Auge, Abandono e Reativação Recente das Ferrovias. Revista Teoria e Evidência Econômica, v. 6, n. 11, pp. 69-91.

McGINNIS, M.A. (1990). The Relative Importance of Service Cost and Service in Freight Transportation Choice: Before and After Deregulation. Transportation Journal, v. 30, pp. 12-9.

MILLER, T.; WISE, D.; CLAIR, L. (1996). Transport Network Design and Mode Choice Modeling for Automobile Distribution: A Case Study. Location Science, vol. 4, n. 1/2, pp. 37-48.

MOKHTARIAN, P.L.; SALOMON, I. (2001). How Derived is the Travel Demand? Some Conceptual and Measurement Considerations. Transportation Research, part A, vol. 34, pp. 695-719.

MOREIRA, C.C.A.; RATTON NETO, H.X. (2003). Análise das Estratégias Competitivas das Concessionárias Ferroviárias. In: XVII ANPET. Congresso Nacional de Ensino e Pesquisa em Transportes, Rio de Janeiro -RJ, 2003. Anais, v. 2, p. 1476-87.

MURPHY, P.R.; HALL, P.K. (1995). The Relative Importance of Service Cost and Service in Freight Transportation Choice Before and After Deregulation: Update. Transportation Journal, v. 35, pp. 30-8.

NEUFVILLE, R. de; STAFFORD, J.H. (1971). Systems Analysis for Engineers and Managers. 1.ed. McGraw-Hill. 
NOVAES, A.G. (1978). Métodos de Otimização: Aplicações aos Transportes. 1.ed. TRANSESP, São Paulo-SP. Edgard Blücher Ltda.

NTC (2001). Manual de Cálculo de Custos e Formação de Preços do Transporte Rodoviário de Cargas. Departamento de Custos operacionais (DECOPE) da Associação Nacional de Transportes de Carga e Logística (NTC). São Paulo - SP.

NTC (2004). Custos Operacionais dos Veículos mais Utilizados (planilha eletrônica em Excel). Disponível para associados em: <http://www.ntcelogistica.org.br/>. Acesso em: 10 dez. 2004.

PDDT (2000). Plano Diretor de Desenvolvimento de Transportes do Estado de São Paulo. Governo do Estado de São Paulo.

PEREIRA, D.R.A.M. (1992). Contribuição ao Estudo dos Fatores de Equivalência de Carga. Dissertação (Mestrado) - Escola Politécnica, Universidade de São Paulo, São Paulo-SP.

POTTS, R.B.; OLIVER, R.M. (1972). Flows in Transportation Network. v. 90 In: Mathematics in Science and Engineering. New York, London. Academic Press.

RAMOS, G.M.; WIDMER, J.A. (2003). Análise Prospectiva da Capacidade de Processamento de Cargas pela Ferrovia no Porto de Santos. In: XVII ANPET. Congresso Nacional de Ensino e Pesquisa em Transportes, Rio de Janeiro -RJ, 2003. Anais, v. 2, p. 744-56.

RAVINDRAN, A.; PHILLIPS, D.T.; SOLBERG, J.J. (1987). Operations Research: Principles and Practice. 2.ed. New York, Chichester, Brisbane, Toronto, Singapore. John Wiley \& Sons.

REGAN, A.C.; GOLOB, T.F. (2000). Impacts of Information Technology on Personal Travel and Commercial Vehicle Operations: Research Challenges and Opportunities. Transportation Research Board, 80 ${ }^{\text {th }}$ Annual Meeting. Paper n. 01-3378.

REIS, N.G. (2003). Em Defesa dos Bitrens de 9 Eixos e da Flexibilização das CVCs. NTCNet. Disponível em: <http://www.ntc.org.br/bitrem_9eixos.htm>. Acesso em: 10 ago. 2004. 
RESOR, R.R.; THOMPSON, G.L. (1999). Do North American Railroads Understand Their Costs? Implications for Strategic Decision Making. Transportation Research Record, 1653, n. 99-1395.

RODRIGUE, J.P. (2004). Challenging the Derived Transport Demand: Geographical Issues in Freight Distribution. Environment \& Planning A. Disponível em: http://people.hofstra.edu/faculty/Jean-

paul_Rodrigue/downloads/Derived\%20Demand.pdf

RORATO, J.R. (2003). Alternativas de Transporte Rodo-Marítimo na Distribuição de Cargas Frigoríficas no Brasil. Dissertação (Mestrado) - Escola de Engenharia de São Carlos, Universidade de São Paulo, São Carlos-SP. 2003.

SARKIS, L.F.P.G. (2000). Resíduos de Serviços de Saúde em Cidades de Médio Porte: Caracterização de Sistemas de Coleta e Aplicação de um Sistema de Informação Geográfica na Roteirização de Veículos de Coleta e Transporte. Dissertação (Mestrado) - Escola de Engenharia de São Carlos, Universidade de São Paulo, São Carlos-SP. 2000 .

SCHROEDER, E.M.; CASTRO, J.C. (2002). Transporte Rodoviário de Cargas: Situação Atual e Perspectivas. Gerência de Estudos Setoriais 2, da Área de InfraEstrutura do BNDES.

SHARMA, R.R.K; SHARMA, K.D. (2000). A New Dual Based Procedure for the Transportatin Problem. European Journal of Operational Research, Theory and Methodology, vol. 122, pp. 611-24.

SILVA, A. N. R. (2003). Ferramentas de um Sistema de Informações Geográficas para Transportes, ilustrado, São Carlos-SP.

SILVA, A. N. R.; WAERDEN, P. van der. (1997). First Steps with a Geographic Information System for Transportation. Ed. São Francisco, Ribeirão Preto-SP.

SIMONETT, O. (1993). Geographic Information Systems for Enviromenment and Development. Geoprocessing Series, vol. 22, Universität Zürich, Zürich.

SOARES, M.G.; GALVANI, P.R.C.; CAIXETA-FILHO, J.V. Características do Transporte de Açúcar no Brasil. Preços Agrícolas, Piracicaba: Fealq, nº 123, p. 19-22, jan. 1997a. 
SOUTHWORTH, F.; PETERSON, B.E. (2000). Intermodal and International Freight Network Modeling. Transportation Research, part C, vol. 8, pp. 147-66.

SOUZA, J.M. (2000). Uso do Sistema de Informações Geográficas na Análise e Otimização do Atendimento a Locais de Potencial Risco de Incêndios, para a Cidade de São Carlos. Dissertação (Mestrado) - Escola de Engenharia de São Carlos, Universidade de São Paulo, São Carlos-SP. (2000).

SOUZA, F.M.; MANFRINATO, J.W.S.; NETO, L.F.F. (2002). Análise Econômica da Implantação de um Sistema de Transporte Combinado Rodo-Ferroviário no Corredor Bauru - São Paulo. Disponível em:

<http://www.simpep.feb.unesp.br/anais10/gestaodaproducao/arq35.PDF>. Acesso em: 28 jan. 2005.

SUN, M. (2002). The Transportation Problem with Exclusionary Side Constraints and Two Branch-and-Bound Algorithms. European Journal of Operational Research, Discrete Optmization, vol. 140, pp. 629-47.

SUN, M.; ARONSON, J.E.; McKEOWN, P.G.; DRINKA, D. (1998). A Tabu Search Heuristic Procedure for the Fixed Charge. European Journal of Operational Research, vol. 106, pp. 451-56.

TADA, M.; ISHII, H. (1996). An Integer Fuzzy Transportation Problem. Computers \& Mathematics with Applications, vol. 31, n. 9, pp. 71-87.

TAKAHASHI, L.S.; SILVA, T.F.; CAIXETA-FILHO, J.V. (2001). Aspectos Logísticos da Importação da Cultura do Alho no Brasil: Um Estudo de Caso. Revista Teoria e Evidência Econômica, v. 9, n. 17, pp. 123-41.

TEIXEIRA, R.G.; CUNHA, C.B. (2002). Heurística para o Problema de Dimensionamento e Roteirização de uma Frota Heterogênea Utilizando o Algoritmo Out-of-Kilter. In: XVI ANPET. Congresso Nacional de Ensino e Pesquisa em Transportes, Natal -RN, 2002. Anais, v. 2, pp. 555-66.

TIAGO, R.P. (2002). Estudo de Pontos Promissores para Instalação de Terminais Intermodais Rodo-Ferroviários de Contêineres no Estado de São Paulo. Dissertação (Mestrado) - Escola de Engenharia de São Carlos, Universidade de São Paulo, São Carlos-SP. 2002.

TRANSPORTE MODERNO (2003). Futuro dos Bitrens de 9 Eixos Ainda Indefinido. Revista Transporte Moderno - Todos os Modais. Ano 41, n 406, outubro. 
TRB (1990a). Transportation Research Board. Special Report 225: Truck Weigth Limits: Issues and Options. National Research Council. Washington, DC.

TRB (1990b). Transportation Research Board. Special Report 227: New Trucks for Greater Productivity and Less Road Wear: Na Evaluation of the Turner Proposal. National Research Council. Washington, DC.

UELZE, R. (1974). Logística Empresarial - Uma Introdução à Administração de Transportes. Ed. Pioneira, São Paulo-SP.

UNIÃO DA AGROINDÚSTRIA CANAVIEIRA DO ESTADO DE SÃO PAULO (UNICA). Disponível em:<http://www.unica.com.br >. Acesso em: 27 ago. 2004.

VICENTE, J.R.; GONÇALVES, J.S.; MARTIN, N.B.; SOUZA, S.A M. (2004). Balança Comercial dos Agronegócios, Janeiro a Dezembro de 2003. São Paulo: IEA/APTA, 2004. Disponível em: <http://www.iea.sp.gov.br/out/icomex.htm>. Acesso em 30 ago. 2004.

VIVIANI, E. (1998). A Utilização de um Sistema de Informação Geográfica como Auxílio à Gerência de Manutenção de Estradas Rurais Não-Pavimentadas. Tese (Doutorado). - Escola de Engenharia de São Carlos, Universidade de São Paulo, São Carlos-SP. 1998.

WIDMER, J.A. (1990). Transporte de Carga Rodoviária: Evolução da Legislação de Dimensões e Pesos no Exterior. In: V ANPET. Congresso Nacional de Ensino e Pesquisa em Transportes, Porto Alegre-RS, 1990. Anais, p. 75.

WIDMER, J.A. (2002). Compatibilidade de Tráfego de Bitrens de 25 Metros com a Infra-Estrutura Viária Brasileira In: COLLOQUIUM DE IMPLEMENTOS RODOVIÁRIOS E MOSTRA DE ENGENHARIA, 1., Caxias do Sul-RS. Anais, p. 712.

WIDMER, J.A. (2004). Proposta de Nomenclatura para Caminhões, Ônibus, CVCs Combinações de Veículos de Carga e CVPs - Combinaçõs de Veículos de Passageiros. In: XVIII ANPET. Congresso Nacional de Ensino e Pesquisa em Transportes, Florianópolis - SC, 2004. Anais, v. 1, p. 624-35.

WINSTON, W. (1995). Operations Research: Applicatins and Algorithms, 3 ed., Ed. Duxbury. Wadsworth, CA. 
WOODBURN, A.G. (2003). A Logistical Perspective on the Potential for Modal Shift of Freight from Road to Rail in Great Britain. International Journal of Transport Management 1, pp. 237-45. 
APÊNDICE A

QUILOMETRAGEM PERCORRIDA MENSALMENTE 


\section{Adoção da Quilometragem Percorrida Mensalmente (QPM)}

A partir de dados coletados de transportadores de açúcar da região Ribeirão Preto, pôde-se elaborar as Tabelas A.1 e A.2 mostradas a seguir. Dessas tabelas, calculando-se as produtividades dos ciclos usina-terminal-usina e usina-porto-usina, durante 27 dias ininterruptos, ter-se-iam produtividades médias de aproximadamente 15.000 e 27.000 quilômetros por mês por combinação.

No entanto, segundo os próprios transportadores, nem sempre se consegue dar utilização total às combinações durante os 27 dias, o que acaba por reduzir essas produtividades. Por esse motivo, optou-se pelas produtividades de 15.000 quilômetros nos ciclos usina-terminal-usina (também chamadas de pontas), e 20.000 quilômetros nos ciclos usina-porto-usina, pois esses são valores intermediários no intervalo real de produtividade das combinações.

Tabela A.1: Dados de um ciclo usina-porto-usina para uma distância média de $1100,0 \mathrm{~km}$.

\begin{tabular}{|c|c|c|c|}
\hline Atividade & Distância média (km) & Tempo (h) & $\mathrm{V}_{\mathrm{m}}(\mathrm{km} / \mathrm{h})$ \\
\hline Carregamento na usina & 0,0 & 3,0 & 0,0 \\
\hline Percurso de ida & 550,0 & 8,5 & 64,7 \\
\hline Descarga no porto & 0,0 & 7,0 & 0,0 \\
\hline Percurso de volta & 550,0 & 7,5 & 73,3 \\
\hline TOTAL & $1.100,0$ & 26,0 & 42,3 \\
\hline
\end{tabular}

Fonte: Transportadora Bombo 
Tabela A.2: Dados de um ciclo usina-terminal-usina para uma distância média de $120,0 \mathrm{~km}$.

\begin{tabular}{lccc}
\hline \multicolumn{1}{c}{ Atividade } & Distância média $(\mathrm{km})$ & Tempo $(\mathrm{h})$ & $\mathrm{V}_{\mathrm{m}}(\mathrm{km} / \mathrm{h})$ \\
\hline Carregamento na usina & 0,0 & 2,0 & 0,0 \\
\hline Percurso de ida & 60,0 & 1,2 & 50,0 \\
\hline Descarga no terminal & 0,0 & 2,0 & 0,0 \\
\hline Percurso de volta & 60,0 & 1,0 & 60,0 \\
\hline TOTAL & 120,0 & 5,2 & 19,4
\end{tabular}

Fonte: Tempos de terminal coletados in loco.

Atenta-se das Tabelas A.1 e A.2 acima, as influências dos tempos de terminais na produtividade das combinações. No primeiro caso, a combinação passa cerca de 10 horas em terminais, o que corresponde a 38,5\% do tempo total. No segundo, a combinação permanece parada por aproximadamente 4 horas, correspondentes a 64,5\% do tempo total. Dessa forma, conclui-se que mesmo que houvesse um aumento das velocidades médias no espaço no segundo caso (ciclo usina-terminal-usina), os ganhos de produtividade seriam pouco significativos, daí a sua baixa quilometragem mensal percorrida.

A respeito das velocidades apresentadas, percebem-se altas médias em ambas as situações, comparadas ao valor médio sugerido pela NTC em seus cálculos para dimensionamento de frotas (NTC, 2004), que é da ordem de 45 quilômetros por hora. Dessa informação deduz-se que em média, há boas condições de infra-estrutura e tráfego no trajeto entre Ribeirão Preto e o Porto de Santos, que possibilitam altas médias de velocidade. 
APÊNDICE B

EXEMPLO DE APLICAÇÃO DA TAXA DE UTILIZAÇÃO 


\section{Exemplo de Aplicação da Taxa de Utilização}

Será apresentado a seguir um exemplo de aplicação da taxa de utilização para que não restem dúvidas quanto a este conceito.

A principal hipótese adotada neste modelo é que o valor do frete de retorno pago é equivalente ao seu custo econômico.

Exemplo:

Dados: Usina A

CVC: 3S2B2

Lotação: 37 toneladas

Demanda (abril): 20.000 toneladas

Custo absoluto do ciclo: $\mathrm{R} \$ 2.000,00$

Frete de retorno: $20 \%$

Pede-se: Calcular os custos absolutos relativos à Usina A no mês de abril, em situações sem e com frete de retorno; calcular a receita gerada pelo frete de retorno.

- Resolução 1: Situação sem incidência de frete de retorno

1.) Determinação do número de viagens:

$$
N_{1}=\frac{\text { demanda }}{\text { lotação }_{1}}=\frac{20.000}{37}=541 \text { viagens }
$$

2.) Determinação do custo absoluto sem incidência de frete de retorno:

$C_{1}=N_{1} \times$ custo $_{\text {ciclo }}=541 \times 2.000=1.082 .000,00 \mathrm{R} \$$ 
- Resolução 2: Situação com incidência de frete de retorno

1.) Determinação do número de viagens:

$N_{2}=N_{1} \times 0,2=541 \times 0,2=108$ viagens

2.) Determinação do custo da viagem de volta:

custo $_{\text {volta }}=$ custo $_{\text {ciclo }} \div 2=2.000 \div 2=1.000,00 \mathrm{R} \$$

3.) Determinação do custo absoluto com incidência de frete de retorno:

$C_{2}=N_{2} \times$ custo $_{\text {volta }}=108 \times 1.000,00=108.000,00 \mathrm{R} \$$

4.) Receita gerada pelo frete de retorno:

$R=C_{2}-C_{1}=1.082 .000,00-108.000,00=974.000,00 \mathrm{R} \$$

Conclusão: A incidência de frete de retorno em $20 \%$ dos ciclos efetuados pela Usina A no mês de abril, resultou na geração de uma receita equivalente ao decréscimo de $\mathrm{R} \$ 108.000,00$ em seus custos absolutos, o que equivale a uma economia de $10,0 \%$ sobre o custo absoluto inicial. Essa receita é o que a Usina A irá arrecadar com o frete de retorno e abater de seu custo absoluto de transporte. 


\section{APÊNDICE C}

DESCRIÇÃO DOS CUSTOS VARIÁVEIS 


\section{Custo Fixo Mensal (CF)}

- Remuneração de capital da composição (RCC): corresponde ao ganho no mercado financeira caso o capital não tivesse sido usado para adquirir o veículo (NTC, 2001).

$$
\begin{aligned}
R C C= & \frac{(V+I+r d+t e+q p i \times(v p+v c+v p r)) \times \operatorname{trcc}}{12}+ \\
& \frac{(V+I+r d+t e+q p i \times(v p+v c+v p r)) \times \operatorname{trp}}{12}
\end{aligned}
$$

onde,

$V$ : valor da unidade tratora $(\mathrm{R} \$)$;

I: valor do implemento sem pneus (R\$);

rd: valor do rodoar $(\mathrm{R} \$)$;

te: valor de instalação do terceiro eixo (R\$);

qpi: quantidade de pneus do implemento;

$v p$ : valor do pneu (R\$);

vc: valor da câmara $(\mathrm{R} \$)$;

vpr: valor do protetor $(\mathrm{R} \$)$;

trcc: 0,12 ao ano (taxa de remuneração do capital da combinação) (NTC);

trp: 0,01 ao ano (taxa de remuneração das peças) (NTC).

- Salário do motorista $(S M)$ : são as despesas com salário e encargos sociais relacionados ao motorista, correspondentes a $96,14 \%$.

$S M=s m \times e s$

onde,

sm: salário do motorista (R\$); 
es: 1,9614 (encargos sociais sobre o salário do motorista) (NTC).

- Salário de oficina (SO): são as despesas com salário e encargos sociais, também correspondentes a 96,14\%. Por hipótese admite-se que um mecânico seja capaz de fazer manutenção em três caminhões pesados por mês (NTC, 2001).

$S O=\frac{s O \times e s}{q v}$

onde,

so: salário médio do mecânico (R\$);

es: 1,9614 (encargos sociais sobre o salário do mecânico) (NTC);

qv: quantidade de veículos atendidos por mecânico em média (NTC).

- Depreciação da unidade tratora (DT): é a quantia que deve ser poupada para que um novo veículo seja comprado ao final da vida útil do veículo usado. Para a depreciação da unidade tratora adotou-se um valor residual de $30 \%$ do valor inicial durante uma vida útil de 120 meses (10 anos), como praticado no mercado. O valor do veículo deve excluir os pneus, os quais são computados na parcela de custos variáveis separadamente.

$D T=\frac{(V-q p t \times(v p+v c+v p r)+r d+t e) \times t d t}{v u t}$

onde,

$V$ : valor da unidade tratora $(\mathrm{R} \$)$;

qpt: quantidade de pneus na unidade tratora;

$v p$ : valor do pneu (R\$);

$v c$ : valor da câmara (R\$);

vpr: valor do protetor $(\mathrm{R} \$)$; 
$r d$ : valor do rodoar $(\mathrm{R} \$)$;

te: valor de instalação do terceiro eixo (R\$);

tdt: 0,70 (taxa de depreciação da unidade tratora);

vut: vida útil da unidade tratora (meses).

- Depreciação do implemento (DI): tem a mesma função da depreciação da unidade tratora, no entanto aqui se adotou um valor residual de $20 \%$ do valor inicial durante uma vida útil de 240 meses (20 anos), como praticado no mercado. Geralmente o valor do implemento informado pelos fabricantes já exclui o valor dos pneus.

$D I=\frac{I \times t d i}{v u i}$

onde,

I: valor do implemento sem pneus (R\$);

tdi: 0,80 (taxa de depreciação do implemento);

vui: vida útil do implemento (meses).

- Licenciamento (LI): são os tributos que devem ser recolhidos antes da circulação dos veículos. No Estado de São Paulo o percentual do IPVA é de 1,5\% sobre o valor do veículo automotor.

$L I=\frac{(D P V A T+I P V A+t l)}{12}$

onde,

DPVAT: seguro por danos pessoais causados por veículos automotores (R\$);

IPVA: $V \times 0,015$ (imposto sobre propriedade de veículos automotores) $(\mathrm{R} \$$ );

tl: taxa de licenciamento paga ao Detran (R\$). 
- Seguro do casco da unidade tratora (SCT): é a despesa mensal alocada para pagamento de um seguro para eventuais sinistros ocorridos com a unidade tratora (colisão, incêndio, roubo etc).

$$
S C T=\frac{(((V+r d) \times i s)+a p) \times I O F}{12}
$$

onde,

$V$ : valor da unidade tratora (R\$);

$r d$ : valor do rodoar $(\mathrm{R} \$)$;

is: 0,10 (coeficiente sobre importância segurada) (NTC);

ap: custo da apólice $(\mathrm{R} \$)$;

IOF: 1,07 (imposto sobre operações financeiras) (NTC).

- Seguro do implemento (SI): tem o mesmo objetivo do seguro de casco da unidade tratora e seu cálculo é similar ao mesmo.

$S I=\frac{((I+q p i \times(v p+v c+v p r) \times i s)+a p) \times I O F}{12}$

onde,

I: valor do implemento sem pneus (R\$);

qpi: quantidade de pneus do implemento;

$v p$ : valor do pneu (R\$);

$v c$ : valor da câmara (R\$);

$v p r$ : valor do protetor $(\mathrm{R} \$)$;

is: 0,10 (coeficiente sobre importância segurada) (NTC); 
ap: custo da apólice (R\$);

IOF: 1,07 (imposto sobre operações financeiras) (NTC).

- Seguro de responsabilidade civil facultativo (SRCF): é a despesa mensal que se destina ao pagamento de um seguro que cobre danos materiais causados a terceiros, já que o valor de cobertura do DPVAT é limitado.

$S R C F=\frac{p d \times I O F}{12}$

onde,

pd: prêmio por danos materiais e pessoais $(\mathrm{R} \$)$;

IOF: 1,07 (imposto sobre operações financeiras) (NTC).

- Seguro da carga (açúcar a granel) (SC): é a despesa mensal destinada ao pagamento de um seguro para a carga, especificamente açúcar a granel, em caso de ocorrência de algum sinistro (roubou, colisão com dano ao produto etc).

No caso específico do açúcar a granel, que é um produto de baixo valor agregado, as seguradoras cobram geralmente um valor médio mensal de R\$ 500,00, incluindo os impostos incididos.

$S C=500$

- Sistema de monitoramento por satélite $(S M S)$ : é a despesa equivalente mensal à aquisição de um sistema de monitoramento por satélite (o qual deve ser compensado ao longo da vida útil da unidade tratora) e a operação de monitoramento por uma empresa especializada.

$S M S=\frac{e m}{v u t}+o m$

onde,

em: valor de aquisição do equipamento de monitoramento (R\$); 
vut: vida útil da unidade tratora (meses);

om: valor mensal da operação de monitoramento (R\$).

- Autorização Especial de Trânsito (AET): é a despesa mensal com a autorização que permite a circulação de combinações em condições especiais diferentes das previstas pela Resolução nº 68/98 do CONTRAN (DENATRAN, 2005).

$A E T=\frac{a e t}{12}$

onde,

aet: valor da licença anual de autorização especial de trânsito (DER-SP).

Atualmente, das CVCs escolhidas para esta investigação, apenas para a combinação 3S3B3 (bitrem de 9 eixos) é aplicada a AET, isto porque essa combinação possui mais de 19,80 metros de comprimento (25,00 metros) e PBTC acima das 57 toneladas (74 toneladas) permitidas pela Resolução nº 68/98, acrescida pela Resolução 164/04 do CONTRAN (BRASIL, 2004). Desta forma, faz-se necessário à aplicação da AET, com o intuito de restringir horários e rodovias (as quais devem possuir sistemas de sinalização adequados), e permitir apenas que motoristas qualificados as dirijam. 


\section{APÊNDICE D}

DESCRIÇÃO DOS CUSTOS VARIÁVEIS 


\section{Custos Variáveis por Quilômetro (CV)}

- Peças, acessórios e material de manutenção $(P M)$ : corresponde à previsão de despesas mensais com peças, acessórios e materiais de manutenção. Adotou-se para esse modelo a taxa de $1 \%$ da combinação completa subtraída do valor dos pneus.

$P M=\frac{((V-q p t \times(v p+v c+v p r)+I+r d+t e) \times t p a m)}{Q P M}$

onde,

$V$ : valor da unidade tratora $(\mathrm{R} \$)$;

qpt: quantidade de pneus na unidade tratora;

$v p$ : valor do pneu (R\$);

$v c$ : valor da câmara $(\mathrm{R} \$)$;

vpr: valor do protetor $(\mathrm{R} \$)$;

I: valor do implemento sem pneus(R\$);

$r d$ : valor do rodoar $(\mathrm{R} \$)$;

te: valor de instalação do terceiro eixo (R\$);

tpam: 0,1 (taxa relativa às despesas mensais com peças, acessórios e material de manutenção) (NTC);

QPM: quilometragem percorrida mensalmente $(\mathrm{km})$.

- Combustível (CO): são as despesas com combustível por quilômetro rodado da unidade tratora.

$C O=\frac{p c}{r c}$ 
onde,

pc: preço do combustível por litro $(\mathrm{R} \$ / \mathrm{l})$;

rc: rendimento do combustível por quilômetro $(\mathrm{km} / \mathrm{l})$.

- Lubrificantes $(L U)$ : é a despesa mensal com a lubrificação interna do motor, da caixa de câmbio e do diferencial. Além disso, admite-se uma taxa de reposição até que a próxima troca se efetue.

$L U=\left(\frac{((c c+r t) \times p o c)}{q t o}\right)+\left(\frac{(c c d \times p o c d)}{q t o c d}\right)$

onde,

cc: capacidade volumétrica do cárter (l);

$r t$ : reposição até a próxima troca (l);

poc: preço do óleo para cárter (R $\$ / \mathrm{l})$;

qto: quilometragem percorrida até a troca de óleo do cárter $(\mathrm{km})$;

ccd: capacidade volumétrica da caixa de câmbio e diferencial (km);

pocd: preço do óleo da caixa de câmbio e diferencial (R $\$ / 1)$;

qtocd: quilometragem percorrida até a troca de óleo da caixa de câmbio e diferencial $(\mathrm{km})$.

- Lavagem e lubrificação externa (LLE): são as despesas com a lavagem e lubrificação externa do veículo.

$$
L L E=\frac{\text { ple }}{q l e}
$$


onde,

ple: preço de lavagem completa da composição (R\$);

qle: quilometragem percorrida até a próxima lavagem e lubrificação externa $(\mathrm{km})$ (NTC).

- Pneus e recauchutagem $(P R)$ : são as despesas resultantes do consumo de pneus na unidade tratora e no implemento. Admite-se uma perda prematura de $20 \%$ dos pneus, ou seja, a cada cinco, apenas quatro permitem recauchutagem. Além disso, admite-se que cada pneu pode ser recauchutado duas vezes.

$P R=\frac{(((v p+v c+v p r) \times q t p) \times c p c+(n r \times p r p \times q t p))}{v u p}$

onde,

$v p$ : valor do pneu $(\mathrm{R} \$)$;

$v c$ : valor da câmara $(\mathrm{R} \$)$;

vpr: valor do protetor $(\mathrm{R} \$)$;

$c p c: 1,2$ (coeficiente de perda do pneu novo) (NTC);

qtp: quantidade total de pneus na combinação;

nr: número de recauchutagens durante a vida útil do pneu;

prp: preço da recauchutagem do pneu (R\$);

vup: vida útil total do pneu, incluindo duas recauchutagens $(\mathrm{km})$. 
APÊNDICE E

PLANILHAS DE CUSTOS OPERACIONAIS RODOVIÁRIOS PARA 15.000 E 20.000 KM/MÊS 


\section{CUSTOS OPERACIONAIS RODOVIÁRIOS PARA \\ O TRANSPORTE DE AÇÚCAR TIPO EXPORTAÇÃO}

$\begin{array}{ll}\text { CUSTOS OPERACIONAIS } & \\ \text { Tipo de Carga: } & \text { Açúcar a granel } \\ \text { Tipo de Veículo: } & \text { VOLVO FH12 4X2 } 380 \\ \text { Implemento: } & \text { Semi-reboque } 3 \text { eixos } \\ \text { KM/MÊS: } & 15.000\end{array}$

Data:

$1 / 6 / 2004$

Dados de entrada:

02 - Valor da unidade tratora

03 - Valor do semi-reboque sem pneus

04 - Valor do $3^{\circ}$ eixo $\mathrm{s} /$ pneus

05 - Rodoar

07 - Taxa para Licenciamento

08 - DEPVAT

09 - Valor do estepe - unidade tratora

10 - Valor do pneu - 1100/22 R- unidade tratora

11 - Valor da câmara - unidade tratora

12. Valor do protetor - unidade tratora

13 - Valor da recapagem a frio - unidade tratora

14 - Quantidade de pneus - unidade tratora

15 - Valor do estepe - semi-reboque

16 - Valor da recauchutagem - semi-reboque

17 - Quantidade pneus - semi-reboque

18 - Salário do motorista $(1,4 \times$ piso SP)

19 - Salário do mecânico - Dissíd.Colet.

20 - Preço combustível p/litro - diesel

21 - Preço óleo do cárter p/litro

22 - Preço óleo câmbio/diferencial p/litro

23 - Preço lavagem da composição

24 - Taxa de remuneração do capital da composição (a.a)

25 - Taxa de remuneração de peças (a.a)

26 - Taxas sobre peças, aces. e mat.manutenção

27 - Encargos Sociais

28 - Quant.veículos atendidos por mecânico

29 - Taxa depreciação da unidade tratora

30 - Vida útil da unidade tratora

31 - Vida útil do semi-reboque
32 - Taxa de depreciação do semi-reboque

33 - Coeficiente sobre importância segurada

34 - Custo da apólice

35 - Imposto sobre Operações Financeiras

36 - Coeficiente sobre importância segurada

37 - S.R.C.F. Prêmio de DM (R\$50 mil)/DP(R\$100 mil)

38 - Quilometragem percorrida mensalmente

39 - Rendimento do combustível

40 - Capacidade de óleo do cárter

41 - Reposição até a próxima troca

42 - Troca de óleo do cárter

43 - Capacidade de óleo caixa diferencial

44 - Troca de óleo diferencial

45 - Periodiocidade lavagem da composição

45 - Periodiocidade lavagem da composiçãa

47 - Vida útil do pneu com duas recapagens

48 - Equipamento de monitoramento por satélite

49 - Sistema de monitoramento po satélite

50 - Seguro da carga (açúcar a granel)

51 - Índice de despesas indiretas (em relação ao custo total operacional)

52 - Índice de despesas diretas (em relação ao custo total operacional)

Resumo dos Custos (A, B e C)

A - Custos Fixos Mensais : $(a+b+c+d+e+f+g+h+i+j+1)$

a - Remuneração de capital da composição

$3.568,75$

b - Salário do motorista

$2.030,96$

c - Salário de oficina

$1.543,29$

d - Depreciação do veículo

e - Depreciação do semi-reboque

350,47

g - Seguro do casco da unidade tratora

$2.548,11$

h - Seguro do casco do implemento

469,32

i - Seguro de responsabilidade civil facultativo

111,67

j - Seguro de carga (açúcar a granel)

500,00

I- Sistema de monitoramento por satélite

325,37

B - Custos Variáveis: $(a+b+c+d+e)$

a - Peças, acessórios e materiais de manutenção

b - Combustíveis 
e - Índice de despesas diretas

a - Remuneração de Capital da composição: [(11)+ (13)]:12

$3.568,75$

01 - Valor da unidade tratora

02 - Rodoar

03 - Valor do semi-reboque

04 - Valor do $3^{\circ}$ eixo s/pneus

05 - Quantidade de pneus - semi-reboque

06 - Valor do pneu do semi-reboque

07 - Valor da câmara do semi-reboque

08 - Valor do protetor do semi-reboque

09 - Valor Total $(01+02+03+04+(05 \times(06+07+08)))$

10 - Taxa de remuneração do capital da composição (a.a)

11 - Valor anual da remuneração do capital: $(09 \times 10)$

12 - Taxa de remuneração de peças (a.a)

13 - Valor anual de remuneração de peças - $(09 \times 12)$

b - Salário do motorista: (01×02)

$2.030,96$

01 - Salário do motorista

02 - Encargos Sociais sobre salário do motorista

c - Salário de oficina: (01:02)×03

01 - Salário do mecânico - média

02 - Quantidade de veículos atendido p/ mecânico

03 - Encargo sociais sobre salário do mecânico

$1.543,29$

d - Depreciação da unidade tratora: ((01-(02×(03+04+05))+06+07)×08):09

01 - Valor da unidade tratora

02 - Quantidade de pneus - unidade tratora

03 - Valor do pneu - unidade tratora

04 - Valor da câmara - unidade tratora

05 - Valor do protetor - unidade tratora

06 - Valor do $3^{\circ}$ eixo $\mathrm{s} /$ pneus

06 - Valor do

08 - Taxa depreciação da unidade tratora

08 - Vida útil da unidade tratora

e - Depreciação do semi-reboque: (01×02):03

01 - Valor do semi-reboque

02 - Taxa de reposição do semi-reboque

03 - Vida útil do semi-reboque

$276.000,00$

863,00
$37.800,00$

0,00

12,00
$1.117,25$

73,41

$329.422,64$

0,12
$39.530,72$

0,01

$3.294,23$

$1.034,78$

034,78
1,96

840,76

2,50
1,96

f - Licenciamento: (01+02+03):12 meses

350,47

01 - DEPVAT

02 - I.P.V.A

03 - Taxa para licenciamento

$276.000,00$

10,00

$1.117,25$

73,41
39,31

0,00

863,00

120,00

$37.800,00$

0,20
240,00

$\mathrm{g}$ - Seguro casco da unidade tratora: [05x(01+02)+03]) $\times 04): 12$ meses

$2.548,11$

01 - Valor da unidade tratora

01 - Valor da
02 - Rodoar

02 - Rodoar

03 - Custo da apólice

05 - Coeficiente sobre importância segurada

h - Seguro casco do implemento: [05x(01+02)+03]×04:12 meses

469,32

01 - Valor do semi-reboque sem pneus

02 - Pneus do semi-reboque

03 - Custo da apólice

04 - Imposto sobre Operações Financeiras - IOF

05 - Coeficiente sobre importância segurada

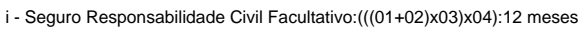

01 - S.R.C.F. prêmio danos materiais e pessoais (corporais)

02 - Imposto sobre Operações Financeiras- IOF

j - Seguro de carga (açúcar a granel) - valor mensal: 01 
01 - Equipamentos de monitoramento

02 -

03 - Vida útil da unidade tratora

$10.844,00$

235,00

B - Custos Variáveis por KM: $(a+b+c+d+e)$

a - Peças, acessórios e materiais de manutenção (((01-(02x(03+04+05))+06+07+08)×09):10

01 - Valor da unidade tratora

02 - Quantidade de pneus - unidade trator

03 - Valor do pneu - unidade tratora

04 - Valor da câmara - unidade tratora

05 - Valor do protetor - unidade tratora

06 - Valor do semi-reboque sem pneus

07 - Valor do $3^{\circ}$ eixo s/pneus

08 - Rodoar

09 - Taxa sobre peças, acessórios mat. de manutenção

10 - Quilometragem percorrida mensalmente

b - Combustível: (01:02)

01 - Preço do combustível por litro

02 - Rendimento do combustivel

C - Lubrificantes: $((01 \times(02+03)): 04)+((05 \times 06): 07)$

01 - Preço do óleo de cárter p/ litro

02 - Capacidade de óleo do cárter

03 - Reposição até a próximo troca

04 - Troca de óleo do cárter

05 - Preço do óleo de câmbio/diferencial p/litro

06 - Capacidade de óleo do diferencial

07 - Troca de óleo do diferencial

d - Lavagem e lubrificação: (01:02)

01 - Preço de lavagem da composição

02 - Periodicidade de lavagem da composição

e - Pneus: $((01+02+03) \times 05 \times 06+(08 \times 04 \times 05)): 07$

01 - Valor do pneu

02 - Valor da câmara

3 - Valor do protetor

04 - Valor da recauchutagem

5 - Quantidades de pneus - unidade tratora mais semi-reboque

06 - Perda de pneu novo

07 - Vida útil do pneu

08 - Número de recapagens
$276.000,00$

10,00

10,00
$.229,97$

73,41
39,31

39,31
$37.800,00$

0,00

863,00

0,01
$15.000,00$

1,39

2,50

0,01

4,85

36,00

9,00
$.000,00$

6,95
32,00

$20.000,00$

0,04

170,00

$4.000,00$

0,22

$1.117,25$

73,41

39,31

245,00

22,00

1,20
$200.000,00$

2,00 


\section{CUSTOS OPERACIONAIS RODOVIÁRIOS PARA \\ O TRANSPORTE DE AÇÚCAR TIPO EXPORTAÇÃO}

CUSTOS OPERACIONAIS
Tipo de Carga:
Tipo de Veículo:
Implemento:
KM/MÊS:

Açúcar a grane

VOLVO FH12 6X2 380

15.000
Caçamba basculante 3 eixos

Dados de entrada:

02 - Valor da unidade tratora

03 - Valor do basculante sem pneus

04 - Valor do $3^{\circ}$ eixo $s /$ pneus

05 - Rodoar

07 - Taxa para Licenciamento

08 - DEPVAT

09 - Valor do estepe - unidade tratora

10 - Valor do pneu - $1100 / 22 \mathrm{R}$ - unidade tratora

11 - Valor da câmara - unidade tratora

12 - Valor do protetor - unidade trator

13 - Valor da recapagem a frio - unidade trator

14 - Quantidade de pneus - unidade tratora

15 - Valor do estepe - basculante

16 - Valor da recauchutagem - basculante

17 - Quantidade pneus - basculante

18 - Salário do motorista ( $1,4 \times$ piso $\mathrm{SP})$

19 - Salário do mecânico - Dissíd.Colet.

20 - Preço combustível p/litro - diesel

21 - Preço óleo do cárter p/litro

22 - Preço óleo câmbio/diferencial p/litro

23 - Preço lavagem da composição

24 - Taxa de remuneração do capital da composição (a.a)

25 - Taxa de remuneração de peças (a.a)

26 - Taxas sobre peças, aces. e mat.manutenção

27 - Encargos Sociais

28 - Quant.veículos atendidos por mecânico

29 - Taxa de depreciação da unidade tratora

30 - Vida útil da unidade tratora

31 - Vida útil do basculante

32 - Taxa de depreciação basculante

33 - Coeficiente sobre importância segurada

34 - Custo da apólice

35 - Imposto sobre Operações Financeiras

36 - Coeficiente sobre importância segurada

37 - S.R.C.F. Prêmio de DM (R\$ 50 mil)/DP(R\$ 100 mil)

38 - Quilometragem percorrida mensalmente

39 - Rendimento do combustível

40 - Capacidade de óleo do cárter

41 - Reposição até a próxima troca

42 - Troca de óleo do cárter

43 - Capacidade de óleo caixa diferencia

44 - Troca de óleo diferencial

45 - Periodiocidade de lavagem da composição

46 - Perda do pneu novo

47 - Vida útil do pneu com duas recapagens

48 - Equipamento de monitoramento por satélite

49 - Operação de monitoramento por satélite

50 - Seguro da carga (açúcar a granel)

51 - Índice de despesas indiretas (em relação ao custo total)

52 - índice de despesas diretas (em relação ao custo total)

Resumo dos Custos (A, B e C)

A - Custos Fixos Mensais : $(a+b+c+d+e+f+g+h+i+j+1)$

a - Remuneração de capital da composição

b - Salário do motorista

c - Salário de oficina

d - Depreciação da unidade tratora

e - Depreciação do basculante

$f$ - Licenciamento

g - Seguro do casco da unidade tratora

h - Seguro do casco do implemento

i - Seguro de responsabilidade civil facultativo

j - Seguro de carga (açúcar a granel)

I- Sistema de monitoramento por satélite

B - Custos Variáveis: $(a+b+c+d+e)$

a - Peças, acessórios e materiais de manutenção

b - Combustíveis

c - Lubrificantes

d - Lavagem e lubrificação
Data:

$1 / 6 / 2004$

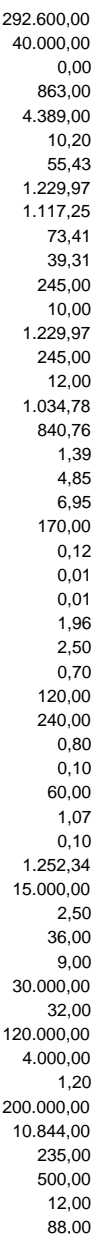

$.600,00$

0,00

$4.389,00$

10,20

$1.229,97$

117,25

39,31

245,00
10,00

10,00
$.229,97$

245,00
12,00

$.034,78$

840,76

4,85

6,95

70,00
0,12

0,01
0,01
0

meses

meses

$\mathrm{R} \$$
$\mathrm{IOF}$

$\mathrm{R} \$ / a n o$

$\mathrm{km}$

$\mathrm{km}$

litros

litros

litros

$\mathrm{km}$

$\mathrm{km}$

$\mathrm{km}$
$\mathrm{R} \$$
$\mathrm{R} \$ / m e ̂ s$

$\mathrm{R} \$ / \mathrm{mês}$

$\%$

$12.734,45$

$3.772,41$

$2.030,96$

660,06

$1.640,12$

133,33

371,22

$2.700,56$

488,74

111,67

500,00

325,37 
c - Quilometragem percorrida mensalmente

06 - Valor do pneu do basculante

07 - Valor da câmara do basculante

08 - Valor do protetor do basculante
09 - Valor Total $(01+02+03+04+(05 \times(06+07+08)))$

10 - Taxa de remuneração do capital da composição (a.a)

11 - Valor anual da remuneração do capital da composição

12 - Taxa de remuneração de peças (a.a)

13 - Valor anual de remuneração de peças - $(09 \times 12)$

$2.030,96$

b - Salário do motorista: (01×02)

01 - Salário do motorista

02 - Encargos Sociais sobre salário do motorista

c - Salário de oficina: (01:02)×03

05 - Valor do protetor - unidade tratora

06 - Valor do $3^{\circ}$ eixo s/ pneus

07 - Rodoar

08 - Taxa de depreciação da unidade tratora

08 - Taxa de depreciação da un

e - Depreciação do basculante: (01×02):03

01 - Valor do basculante

02 - Taxa de depreciação do basculante

03 - Vida útil do basculante

f - Licenciamento: (01+02+03):12 meses

03 - Taxa para licenciamento

$\mathrm{g}$ - Seguro casco da unidade tratora: [05x(01+02)+03])x04):12 meses

01 - Valor do basculante sem pneus

02 - Pneus do basculante

03 - Custo da apólice

04 - Imposto sobre Operações Financeiras - IOF

05 - Coeficiente sobre importância segurada

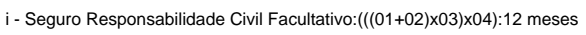

01 - S.R.C.F. prêmio danos materiais e pessoais (corporais)

02 - Imposto sobre Operações Financeiras- IOF

j - Seguro de carga (açúcar a granel) - valor mensal: 01 
a - Peças, acessórios e materiais de manutenção (((01-(02×(03+04+05))+06+07+08)×09):10

01 - Valor da unidade tratora

02 - Quantidade de pneus - unidade tratora

03 - Valor do pneu - unidade tratora

04 - Valor da câmara - unidade tratora

05 - Valor do protetor - unidade tratora

06 - Valor do basculante

07 - Valor do $3^{\circ}$ eixo s/pneus

08 - Rodoar

09 - Taxa sobre peças, acessórios mat. de manutenção

10 - Quilometragem percorrida mensalmente

b - Combustível: (01:02)

$292.600,00$

10,00

$1.229,97$
73,41

39,31

$40.000,00$

0,00
863,00

0,01

$15.000,00$

01 - Preço do combustível por litro

02 - Rendimento do combustível

1,39

2,50

C - Lubrificantes: $((01 \times(02+03)): 04)+((05 \times 06): 07)$

01 - Preço do óleo de cárter $\mathrm{p} /$ litro

02 - Capacidade de óleo do cárter

03 - Reposição até a próximo troc

04 - Troca de óleo do cárter

05 - Preço do óleo de câmbio/diferencial p/ litro

06 - Capacidade de óleo do diferencial

07 - Troca de óleo do diferencial

d - Lavagem e lubrificação: (01:02)

01 - Preço de lavagem da composição

02 - Periodicidade de lavagem da composição

e - Pneus: $((01+02+03) \times 05 \times 06)+(08 \times 04 \times 05)): 07$

01 - Valor do pneu

02 - Valor da câmara

03 - Valor do protetor

04 - Valor da recauchutagem

05 - Quantidades de pneus - unidade tratora mais basculante

06 - Perda de pneu novo

07 - Vida útil do pneu

08 - Número de recapagens
0,01

0,04

$4.000,00$

$1.117,25$

73,41

39,31
245,00

22,00

$200.000,00$ 


\section{CUSTOS OPERACIONAIS RODOVIÁRIOS PARA \\ O TRANSPORTE DE AÇÚCAR TIPO EXPORTAÇÃO}

$\begin{array}{ll}\text { CUSTOS OPERACIONAIS } & \\ \text { Tipo de Carga: } & \text { Açúcar a granel } \\ \text { Tipo de Veículo: } & \text { VOLVO FH12 6X4 420 } \\ \text { Implemento: } & \text { Bitrem graneleiro } 4 \text { eixos } \\ \text { KM/MÊS: } & 15.000\end{array}$

Data:

1/6/2004

Dados de entrada:

02 - Valor da unidade tratora

03 - Valor do implemento bitrem sem pneus

04 - Valor do $3^{\circ}$ eixo $s /$ pneus

05 - Rodoar

06 - I.P.V.A

07 - Taxa para Licenciamento

08- DEPVAT

09 - Valor do estepe - unidade tratora

10 - Valor do pneu - 1100/22 R- unidade tratora

11 - Valor da câmara - unidade tratora

12 - Valor do protetor - unidade tratora

13 - Valor da recapagem a frio - unidade tratora

14 - Quantidade de pneus - unidade tratora

15 - Valor do estepe - implemento bitrem

16 - Valor da recauchutagem - implemento bitrem

17 - Quantidade pneus - implemento bitrem

18 - Salário do motorista ( $1,4 \times$ piso $\mathrm{SP})$

19 - Salário do mecânico - Dissíd.Colet.

20 - Preço combustível p/litro - diesel

21 - Preço óleo do cárter p/litro

22 - Preço óleo câmbio/diferencial p/litro

22- Preço lavagem da composição

24 - Taxa de remuneração do capital da composição (a.a)

25 - Taxa de remuneração de peças (a.a)

26 - Taxas sobre peças, aces. e mat.manutenção

27 - Encargos Sociais

28 - Quant.veículos atendidos por mecânico

29 - Taxa de depreciação da unidade tratora

30 - Vida útil da unidade tratora

31 - Vida útil do implemento bitrem

32 - Taxa de depreciação da unidade rebocada

33 - Coeficiente sobre importância segurada

34 - Custo da apólice

35 - Imposto sobre Operações Financeiras

36 - Coeficiente sobre importância segurada

37 - S.R.C.F. Prêmio de DM (R\$ 50 mil)/DP(R\$100 mil)

38 - Quilometragem percorrida mensalmente

39 - Rendimento do combustível

40 - Capacidade de óleo do cárter

41 - Reposição até a próxima troca

42 - Troca de óleo do cárter

43 - Capacidade de óleo caixa diferencial

44 - Troca de óleo diferencial

45 - Periodiocidade lavagem da composição

46- Perda do pneu novo

47 - Vida útil do pneu com duas recapagens

48 - Equipamento de monitoramento por satélite

49 - Operação de monitoramento por satélite

50 - Seguro da carga (açúcar a granel)

51 - Índice de despesas indiretas (em relação ao custo total operacional)

52 - Índice de despesas diretas (em relação ao custo total operacional)

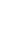

(1)

Resumo dos Custos (A, B e C)

A - Custos Fixos Mensais : $(a+b+c+d+e+f+g+h+i+j+l)$

$15.135,37$

a - Remuneração de capital da composição

$357.039,06$
$64.260,00$
0,00
863,00
$5.355,59$
10,20
55,43
$1.229,97$
$1.117,25$
73,41
39,31
245,00
10,00
$1.229,97$
245,00
16,00
$1.034,78$
840,76
1,39
4,85
6,95
170,00
0,12
0,01
0,01
1,96
2,50
0,70
120,00
240,00
0,80
0,10
60,00
1,07
0,10
$1.252,34$
$15.000,00$
2,20
36,00
9,00
$30.000,00$
65,00
$120.000,00$
$4.000,00$
1,20
$200.000,00$
$10.844,00$
235,00
500,00
12,00
88,00

b - Salário do motorista

$4.786,62$

$2.030,96$

660,06

$2.016,01$

214,20

451,77

f - Licenciamento

$3.292,38$

$\mathrm{g}$ - Seguro do casco da unidade tratora

746,33

111,67

i- Seguro de responsabilidade civil facultativo

500,00

j - Seguro da carga (açúcar a granel)

325,37

I- Sistema de monitoramento por satélite

B - Custos Variáveis: $(a+b+c+d+e)$

a - Peças, acessórios e materiais de manutenção

c - Lubrificantes 
a - Remuneração de Capital da composição [(11)+ (13)]:12

$4.786,62$

01 - Valor da unidade tratora

02 - Rodoar

03 - Valor do implemento bitrem

04 - Valor do $3^{\circ}$ eixo s/pneus

05 - Quantidade de pneus - implemento bitrem

06 - Valor do pneu do implemento bitrem

07 - Valor da câmara do implemento bitrem

08 - Valor do protetor do implemento bitrem
09 - Valor Total $(01+02+03+04+(05 x(06+07+08))$

10 - Taxa de remuneração do capital da composição (a.a)

11 - Valor anual da remuneração do capital

12 - Taxa de remuneração de peças (a.a)

13 - Valor anual de remuneração de peças - $(09 \times 12)$

$2.030,96$

b - Salário do motorista: (01×02)

01 - Salário do motorista

02 - Encargos Sociais sobre salário do motorista

c-

02 - Quantidade de veículos atendido $p /$ mecânico

03 - Encargo sociais sobre salário do mecânico

d - Depreciação da unidade tratora: ((01-(02×(03+04+05))+06+07) x08):09

01 - Valor da unidade tratora

02 - Quantidade de pneus - unidade tratora

03 - Valor do pneu - unidade tratora

04 - Valor da câmara - unidade tratora

05 - Valor do protetor - unidade tratora

06 - Valor do $3^{\circ}$ eixo $\mathrm{s} /$ pneus

07 - Rodoar

08 - Taxa de depreciação da unidade tratora

09 - Vida útil da unidade tratora

e - Depreciação do implemento bitrem: (01×02):03

01 - Valor do implemento bitrem

02 - Taxa de depreciaçào implemento bitrem

03 - Vida útil do implemento bitrem

f - Licenciamento: (01+02+03):12 meses

03 - Taxa para licenciamento

g - Seguro casco da unidade tratora: [05x(01+02)+03])x04):12 meses

01 - Valor da unidade tratora

02 - Rodoar

03 - Custo da apólice

03 - Custo da apólice

04 - Coeficiente sobre importância segurada

h - Seguro casco do implemento bitrem: [05x(01+02)+03]x04:12 meses

01 - Valor do implemento bitrem sem pneus

02 - Pneus do implemento bitrem

03 - Custo da apólice

04 - Imposto sobre Operações Financeiras - IOF

05 - Coeficiente sobre importância segurada

i - Seguro Responsabilidade Civil Facultativo:(01+02):12 meses

01 - S.R.C.F. prêmio danos materiais e pessoais (corporais)

02 - Imposto sobre Operaç̃̃es Financeiras- IOF

j - Seguro de carga (açúcar a granel) - valor mensal: 01

01 - Equipamentos de monitoramento

02 - Operação de monitoramento - valor mensal

03 - Vida útil da unidade tratora 
a - Peças, acessórios e materiais de manutenção (((01-(02×(03+04+05))+06+07+08)×09):10

0,27

01 - Valor da unidade tratora

02 - Quantidade de pneus - unidade tratora

03 - Valor do pneu - unidade tratora

04 - Valor da câmara - unidade tratora

05 - Valor do protetor - unidade tratora

06 - Valor do implemento bitrem sem pneus

07 - Valor do $3^{\circ}$ eixo s/pneus

08 - Rodoar

09 - Taxa sobre peças, acessórios mat. de manutenção

10 - Quilometragem percorrida mensalmente

b - Combustível: (01:02)

01 - Preço do combustível por litro

02 - Rendimento do combustível

C - Lubrificantes: ((01×(02+03)):04)+((05×06) : 07)

01 - Preço do óleo de cárter $\mathrm{p} /$ litro

02 - Capacidade de óleo do cárter

03 - Reposição até a próximo troc

04 - Troca de óleo do cárter

05 - Preço do óleo de câmbio/diferencial p/ litro

06 - Capacidade de óleo do diferencial

07 - Troca de óleo do diferencial

d - Lavagem e lubrificação: (01:02)

01 - Preço de lavagem da composição

02 - Periodicidade de lavagem da composição

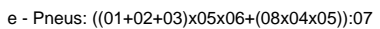

01 - Valor do pneu

02 - Valor da câmara

03 - Valor do protetor

04 - Valor da recauchutagem

05 - Quantidades de pneus - unidade tratora mais implemneto bitrem

06 - Perda de pneu novo

07 - Vida útil do pneu

08 - Número de recapagens
$357.039,06$ 10,00 1117,25 39,31 64.260,00

0,00
863,00

863,00
0,01

$15.000,00$

$30.000,00$
6,95

6,95
65,00

$120.000,00$

170,00
$4.000,00$

0,26

$1.117,25$

73,41

39,31
245,00

26,00

200.000,00

2,00 


\section{CUSTOS OPERACIONAIS RODOVIÁRIOS PARA \\ O TRANSPORTE DE AÇÚCAR TIPO EXPORTAÇÃO}

CUSTOS OPERACIONAIS
Tipo de Carga:
Tipo de Veículo:
Implemento:
KM/MÊS:

Açúcar a grane

VOLVO FH12 6X4 420

Bitrem
15.000

Dados de entrada:

02 - Valor da unidade tratora

03 - Valor do implemento bitrem sem pneus

04 - Valor do $3^{\circ}$ eixo $\mathrm{s} /$ pneus

05 - Rodoar

06 - I.P.V.A

07 - Taxa para Licenciamento

08 - DEPVAT

09 - Valor do estepe - unidade tratora

10 - Valor do pneu - 1100/22 R- unidade tratora

11 - Valor da câmara - unidade tratora

12 - Valor do protetor - unidade tratora

13 - Valor da recapagem a frio - unidade tratora

14 - Quantidade de pneus - unidade tratora

15 - Valor do estepe - implemento bitrem

16 - Valor da recauchutagem - implemento bitrem

17- Quantidade pneus - implemento bitrem

18 - Salário do motorista (1,4 $\times$ piso $\mathrm{SP})$

19 - Salário do mecânico - Dissíd.Colet.

20 - Preço combustível p/litro - diesel

21 - Preço óleo do cárter p/litro

22 - Preço óleo câmbio/diferencial p/litro

23 - Preço lavagem da composição

24 - Taxa de remuneração do capital da composição (a.a)

25 - Taxa de remuneração de peças (a.a)

26 - Taxas sobre peças, aces. e mat.manutenção

27 - Encargos Sociais

28 - Quant.veículos atendidos por mecânico

29 - Taxa de depreciação da unidade tratora

30 - Vida útil da unidade tratora

31 - Vida útil do implemento bitrem

32 - Taxa de depreciação da unidade rebocada

33 - Coeficiente sobre importância segurada

34 - Custo da apólice

35 - Imposto sobre Operações Financeiras

36 - Coeficiente sot

37 - S.R.C.F. Prêmio de DM (R\$ 50 mil)/DP(R\$100 mil)

38 - Quilometragem percorrida mensalmente

39 - Rendimento do combustível

40 - Capacidade de óleo do cárter

41 - Reposição até a próxima tro

42 - Troca de oleo do cárter

43 - Capacidade de óleo caixa diferencia

44 - Troca de óleo diferencial

45 - Periodiocidade lavagem da composição

46 - Perda do pneu novo

47 - Vida útil do pneu com duas recapagens

48 - Autorização Especial de Trânsito

49 - Equipamento de monitoramento por satélite

50 - Operação de monitormente por satélite

51 - Seguro de carga (açúcar a granel)

52 - Índice de despesas indiretas (em relação ao custo total operacional)

53 - Índice de despesas diretas (em relação ao custo total operacional)

Resumo dos Custos (A, B e C)

$A$ - Custos Fixos Mensais : $(a+b+c+d+e+f+g+h+i+j+l+m)$

a - Remuneração de capital da composição

b - Salário do motorista

c - Salário de oficina

d - Depreciação da unidade tratora

e - Depreciação do implemento bitrem

$f$ - Licenciamento

$\mathrm{g}$ - Seguro do casco da unidade tratora

h - Seguro do casco do implemento bitrem

i - Seguro de responsabilidade civil facultativo

j- Seguro da carga (açúcar a granel)

I - Sistema de monitoramento por satélite

m - Autorização Especial de Trânsito

B - Custos Variáveis: $(a+b+c+d+e)$

Data:

1/6/2004

$96.390,00$

0,00

863,00
$5.355,59$

10,20

55,43

1.229,97

$1.117,25$
73,41

73,41
39,31

245,00

10,00
1229,97

229,97
245,00

24,00
24,00

$1.034,78$
840,76

840,76

1,39
5,71

6,95

170,00

0,12
0,01

0,01
1,96

1,96
2,50

0,70
120,00

meses

meses

$\mathrm{R} \$$
$\mathrm{IOF}$

$\mathrm{R} \$ /$ ano

$\mathrm{km}$

$\mathrm{km}$

litros

litros

litros

$\mathrm{km}$

$\mathrm{km}$

$\mathrm{R} \$ /$ ano

$\mathrm{R} \$$

$\mathrm{R} \$ /$ mês

$\mathrm{R} \$$ /mês

$\%$

120,00
240,00

0,80

0,10
60,00

1,07
0,10

0,10
$.252,34$

$1.252,34$

$5.000,00$
2,00

36,00

9,00
$.000,00$

65,00
$.000,00$

$120.000,00$

$4.000,00$
1,20

1,20
$200.000,00$

$\begin{array}{r}1,000,00 \\ 90,00 \\ \hline\end{array}$

$10.844,00$
235,00

235,00

500,00
12,00

12,00
88,00

a - Peças, acessórios e materiais de manutenção 
03 - Valor do implemento bitrem

04 - Valor do $3^{\circ}$ eixo s/pneus

05 - Quantidade de pneus - implemento bitrem

06 - Valor do pneu do implemento bitrem

07 - Valor da câmara do implemento bitrem

08 - Valor do protetor do implemento bitrem

09 - Valor Total $(01+02+03+04+(05 \times(06+07+08)))$

10 - Taxa de remuneração do capital da composição (a.a)

11 - Valor anual da remuneração do capital

12 - Taxa de remuneração de peças (a.a)

b - Salário do motorista: (01×02)

01 - Salário do mecânico - média

02 - Quantidade de veículos atendido p/ mecânico

03 - Encargo sociais sobre salário do mecânico

$2.016,01$

01 - Valor da unidade tratora

02 - Quantidade de pneus - unidade tratora

03 - Valor do pneu - unidade tratora

04 - Valor da câmara - unidade tratora

05 - Valor do protetor - unidade tratora

06 - Valor do

07 - Rodoar
08 - Taxa de depreciação da unidade tratora

09 - Vida útil da unidade tratora

e - Depreciação do implemento bitrem: (01×02):03

01 - Valor do implemento bitrem

02 - Taxa de depreciaçào implemento bitrem

03 - Vida útil do implemento bitrem

f - Licenciamento: (01+02+03):12 meses

03 - Taxa para licenciamento

$\mathrm{g}$ - Seguro casco da unidade tratora: $[05 \times(01+02)+03]) \times 04): 12$ meses

04 - Imposto sobre Operações Financeiras - IOF

05 - Coeficiente sobre importância segurada

h - Seguro casco do implemento bitrem: [05x(01+02)+03] x04:12 meses

01 - Valor do implemento bitrem sem pneus

03 - Custo da apólice

04 - Imposto sobre Operações Financeiras - IOF

05 - Coeficiente sobre importância segurada

60,00

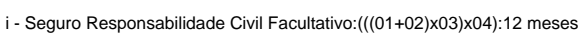


01 - Equipamentos de monitoramento

02 - Operação de monitoramento - valor mensal

02 - Operação de monitoramento -

$10.844,00$

235,00

m - Autorização Especial de Trânsito-AET: 01:12 meses

01 - Valor da licença anual (DER-SP)

90,00

B - Custos Variáveis por KM: $(a+b+c+d+e)$

a - Peças, acessórios e materiais de manutenção (((01-(02x(03+04+05))+06+07+08)x09):10

01 - Valor da unidade tratora

$357.039,06$

02 - Quantidade de pneus - unidade trator

03 - Valor do pneu - unidade tratora

04 - Valor da câmara - unidade tratora

05 - Valor do protetor - unidade tratora

06 - Valor do implemento bitrem sem pneus

07 - Valor do $3^{\circ}$ eixo s/pneus

08 - Rodoar

09 - Taxa sobre peças, acessórios mat. de manutenção

10 - Quilometragem percorrida mensalmente

b - Combustível: (01:02)

$$
\begin{array}{r}
7.039,06 \\
10,00 \\
1.229,97 \\
73,41 \\
39,31 \\
96.390,00 \\
0,00 \\
863,00 \\
0,01 \\
0,00
\end{array}
$$

$15.000,00$

01 - Preço do combustível por litro

02 - Rendimento do combustível

1,39

2,00

C - Lubrificantes: $((01 \times(02+03)): 04)+((05 \times 06): 07)$

01 - Preço do óleo de cárter p/ litro

02 - Capacidade de óleo do cárter

03 - Reposição até a próximo troca

04 - Troca de óleo do cárter

05 - Preço do óleo de câmbio/diferencial p/ litro

06 - Capacidade de óleo do diferencial

07 - Troca de óleo do diferencial

01 - Preço de lavagem da composição

02 - Periodicidade de lavagem da composição

70,00

$4.000,00$

e - Pneus: $((01+02+03) \times 05 \times 06+(08 \times 04 \times 05)): 07$

01 - Valor do pneu

02 - Valor da câmara

03 - Valor do protetor

04 - Valor da recauchutagem

05 - Quantidades de pneus - unidade tratora mais implemneto bitrem

06 - Perda de pneu novo

08 - Número de recapagens 


\title{
CUSTOS OPERACIONAIS RODOVIÁRIOS PARA \\ O TRANSPORTE DE AÇÚCAR TIPO EXPORTAÇÃO
}

\begin{tabular}{ll} 
CUSTOS OPERACIONAIS & \\
Tipo de Carga: & Açúcar a granel \\
Tipo de Veículo: & VOLVO FH12 $4 \times 2 \quad 380$ \\
Implemento & Semi-reboque 3 eixos \\
KM/MÊS: & 20.000 \\
\hline
\end{tabular}

\author{
Data:
}

$1 / 6 / 2004$

Dados de entrada:

02 - Valor da unidade tratora

03 - Valor do semi-reboque sem pneus

04 - Valor do $3^{\circ}$ eixo $\mathrm{s} /$ pneus

05 - Rodoar

06 - I.P.V.A

07 - Taxa para Licenciamento

08 - DEPVAT

09 - Valor do estepe - unidade tratora

10 - Valor do pneu - 1100/22 R- unidade tratora

11 - Valor da câmara - unidade tratora

12 - Valor do protetor - unidade tratora

13 - Valor da recapagem a frio - unidade tratora

14 - Quantidade de pneus - unidade tratora

15 - Valor do estepe - semi-reboque

16- Valor da recauchutagem - semi-reboque

17 - Quantidade pneus - semi-reboque

18 - Salário do motorista ( $1,4 \times$ piso SP)

19 - Salário do mecânico - Dissíd.Colet.

20 - Preço combustível p/litro - diesel

21 - Preço óleo do cárter p/litro

22 - Preço óleo câmbio/diferencial p/litro

23 - Preço lavagem da composição

24 - Taxa de remuneração do capital da composição (a.a)

25 - Taxa de remuneração de peças (a.a)

26 - Taxas sobre peças, aces. e mat.manutenção

27 - Encargos Sociais

28 - Quant.veículos atendidos por mecânico

29 - Taxa depreciação da unidade tratora

30 - Vida útil da unidade tratora

31 - Vida útil do semi-reboque

32 - Taxa de depreciação do semi-reboque

33 - Coeficiente sobre importância segurada

34 - Custo da apólice

35 - Imposto sobre Operações Financeiras

36 - Coeficiente sobre importância segurada

37 - S.R.C.F. Prêmio de DM (R\$50 mil)/DP(R\$100 mil)

38 - Quilometragem percorrida mensalmente

39 - Rendimento do combustível

40 - Capacidade de óleo do cárter

41 - Reposição até a próxima troca

42 - Troca de óleo do cárter

43 - Capacidade de óleo caixa diferencial

44 - Troca de óleo diferencial

45 - Periodiocidade lavagem da composição

46 - Perda do pneu novo

47 - Vida útil do pneu com duas recapagens

48 - Equipamento de monitoramento por satélite

49 - Sistema de monitoramento po satélite

50 - Seguro da carga (açúcar a granel)

51 - Indice de despesas indiretas (em relação ao custo total operacional)

52 - Índice de despesas diretas (em relação ao custo total operacional)

Resumo dos Custos (A, B e C)

A - Custos Fixos Mensais : $(a+b+c+d+e+f+g+h+i+j+1)$

a - Remuneração de capital da composição

$3.568,75$

b - Salário do motorista

$2.030,96$

c - Salário de oficina

660,06

d - Depreciação do veículo

$1.543,29$

e - Depreciação do semi-reboque

$f$ - Licenciamento

$\mathrm{g}$ - Seguro do casco da unidade tratora

$\mathrm{h}$ - Seguro do casco do implemento

i - Seguro de responsabilidade civil facultativo

j - Seguro de carga (açúcar a granel)

500,00

I- Sistema de monitoramento por satélite

325,37

B - Custos Variáveis: $(a+b+c+d+e)$

a - Peças, acessórios e materiais de manutenção

b- Combustíveis 
c - Quilometragem percorrida mensalmente

e - Índice de despesas diretas

a - Remuneração de Capital da composição: [(11)+ (13)]:12

$3.568,75$

01 - Valor da unidade tratora

02 - Rodoar

03 - Valor do semi-reboque

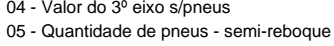

06 - Valor do pneu do semi-reboque

07 - Valor da câmara do semi-reboque

08 - Valor do protetor do semi-reboque

09 - Valor Total $(01+02+03+04+(05 \times(06+07+08)))$

10 - Taxa de remuneração do capital da composição (a.a)

11 - Valor anual da remuneração do capital: $(09 \times 10)$

12 - Taxa de remuneração de peças (a.a)

13 - Valor anual de remuneração de peças - $(09 \times 12)$

b - Salário do motorista: (01×02)

$2.030,96$

01 - Salário do motorista

02 - Encargos Sociais sobre salário do motorista

c - Salário de oficina: (01:02)×03

01 - Salário do mecânico - média

02 - Quantidade de veículos atendido p/ mecânico

03 - Encargo sociais sobre salário do mecânico

$1.543,29$

d - Depreciação da unidade tratora: ((01-(02×(03+04+05))+06+07)×08):09

01 - Valor da unidade tratora

02 - Quantidade de pneus - unidade tratora

03 - Valor do pneu - unidade tratora

04 - Valor da câmara - unidade tratora

05 - Valor do protetor - unidade tratora

06 - Valor do $3^{\circ}$ eixo $\mathrm{s} /$ pneus

06 - Valor do

07 - Rodoar

08 - Taxa depreciação da unidade

e - Depreciação do semi-reboque: (01×02):03

01 - Valor do semi-reboque

02 - Taxa de reposição do semi-reboque

03 - Vida útil do semi-reboque

f - Licenciamento: (01+02+03):12 meses

01 - DEPVAT

02 - I.P.V.A

03 - Taxa para licenciamento

$276.000,00$

$\mathrm{g}$ - Seguro casco da unidade tratora: $[05 \times(01+02)+03]) \times 04): 12$ meses

01 - Valor da unidade tratora

01 - Valor da

02 - Rodoar
03 - Custo da apólice

03 - Custo da apólice

05 - Coeficiente sobre importância segurada

h - Seguro casco do implemento: [05x(01+02)+03]×04:12 meses

01 - Valor do semi-reboque sem pneus

02 - Pneus do semi-reboque

03 - Custo da apólice

04 - Imposto sobre Operações Financeiras - IOF

05 - Coeficiente sobre importância segurada

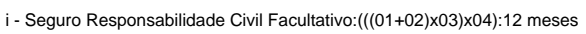

01 - S.R.C.F. prêmio danos materiais e pessoais (corporais)

02 - Imposto sobre Operações Financeiras- IOF

j - Seguro de carga (açúcar a granel) - valor mensal: 01 
03 - Valor do pneu - unidade tratora

04 - Valor da câmara - unidade tratora

05 - Valor do protetor - unidade tratora

06 - Valor do semi-reboque sem pneus

07 - Valor do $3^{\circ}$ eixo $\mathrm{s} /$ pneus

08 - Rodoar

09 - Taxa sobre peças, acessórios mat. de manutenção

10 - Quilometragem percorrida mensalmente

b - Combustível: (01:02)

$276.000,00$

10,00

$1.229,97$

73,41
39,31

$37.800,00$
0,00

0,00

863,00

$20.000,00$

01 - Preço do combustível por litro

02 - Rendimento do combustível

1,39

2,50

C - Lubrificantes: ((01×(02+03)):04)+((05×06) : 07)

01 - Preço do óleo de cárter $\mathrm{p} /$ litro

02 - Capacidade de óleo do cárter

03 - Reposição até a próximo troca

04 - Troca de óleo do cárter

05 - Preço do óleo de câmbio/diferencial p/ litro

06 - Capacidade de óleo do diferencial

07 - Troca de óleo do diferencial

d - Lavagem e lubrificação: (01:02)

01 - Preço de lavagem da composição

02 - Periodicidade de lavagem da composição

e - Pneus: $((01+02+03) \times 05 \times 06+(08 \times 04 \times 05)): 07$

0,22

01 - Valor do pneu

02 - Valor da câmara

03 - Valor do protetor

04 - Valor da recauchutagem

05 - Quantidades de pneus - unidade tratora mais semi-reboque

06 - Perda de pneu novo

07 - Vida útil do pneu

08 - Número de recapagens 


\section{CUSTOS OPERACIONAIS RODOVIÁRIOS PARA \\ O TRANSPORTE DE AÇÚCAR TIPO EXPORTAÇÃO}

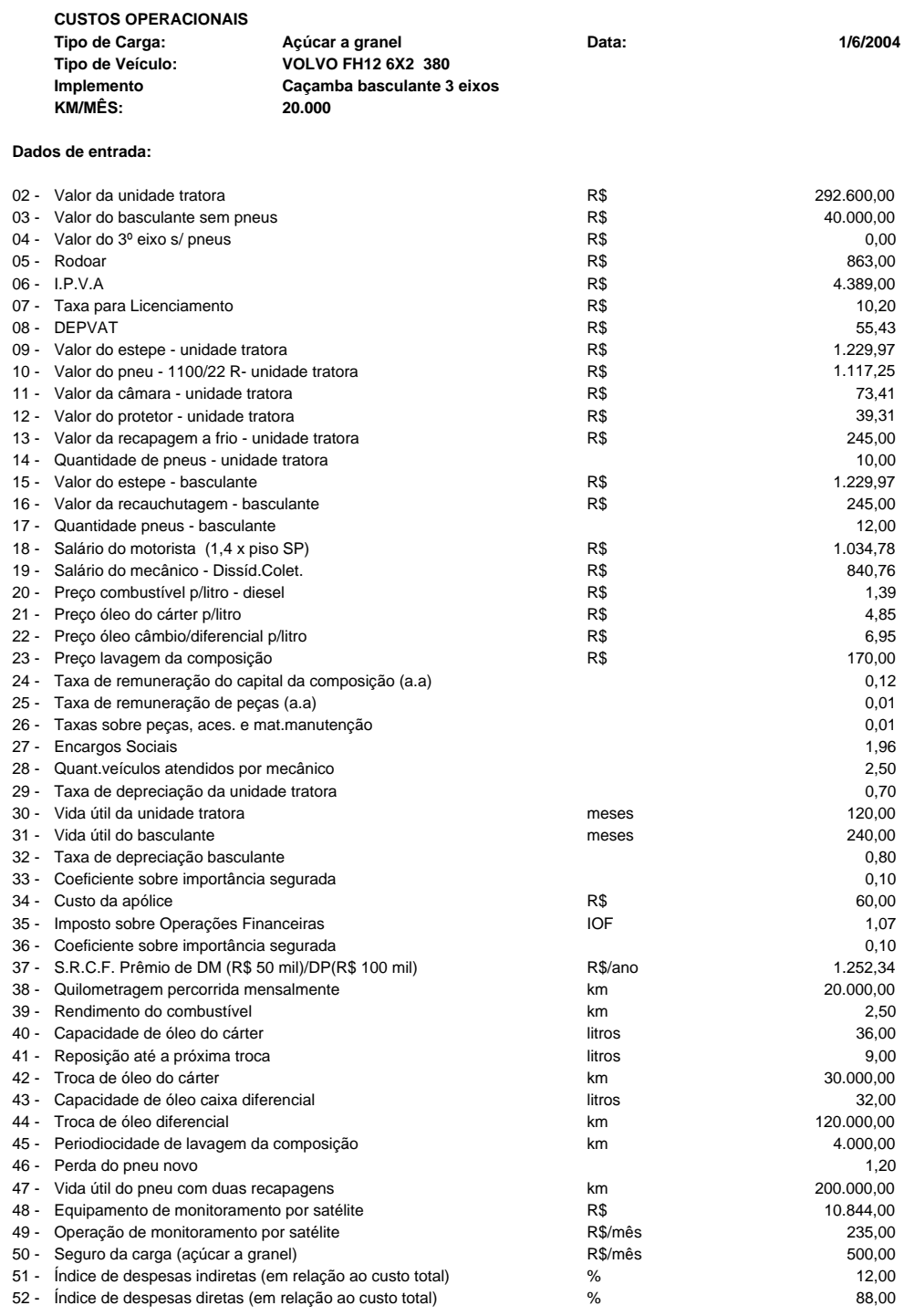

Resumo dos Custos (A, B e C)

A - Custos Fixos Mensais : $(a+b+c+d+e+f+g+h+i+j+l)$

a - Remuneração de capital da composição

$3.772,41$

b - Salário do motorista

c - Salário de oficina

d - Depreciação da unidade tratora

e - Depreciação do basculante

$f$ - Licenciamento

g - Seguro do casco da unidade tratora

h - Seguro do casco do implemento

i - Seguro de responsabilidade civil facultativo

j - Seguro de carga (açúcar a granel)

I- Sistema de monitoramento por satélite

B - Custos Variáveis: $(a+b+c+d+e)$

a - Peças, acessórios e materiais de manutenção

b - Combustíveis 
c - Quilometragem percorrida mensalmente

06 - Valor do pneu do basculante

07 - Valor da câmara do basculante

08 - Valor do protetor do basculante

09 - Valor Total $(01+02+03+04+(05 \times(06+07+08)))$

10 - Taxa de remuneração do capital da composição (a.a)

11 - Valor anual da remuneração do capital da composição

12 - Taxa de remuneração de peças (a.a)

13 - Valor anual de remuneração de peças - $(09 \times 12)$

$.030,96$

b - Salário do motorista: (01×02)

01 - Salário do motorista

02 - Encargos Sociais sobre salário do motorista

c - Salário de oficina: (01:02)×03

05 - Valor do protetor - unidade tratora

06 - Valor do $3^{\circ}$ eixo s/ pneus

07 - Rodoar

08 - Taxa de depreciação da unidade tratora

08 - Taxa de depreciação da uni

e - Depreciação do basculante: (01×02):03

01 - Valor do basculante

02 - Taxa de depreciação do basculante

03 - Vida útil do basculante

f - Licenciamento: (01+02+03):12 meses

03 - Taxa para licenciamento

$\mathrm{g}$ - Seguro casco da unidade tratora: [05x(01+02)+03])x04):12 meses

j - Seguro de carga (açúcar a granel) - valor mensal: 01 
a - Peças, acessórios e materiais de manutenção (((01-(02×(03+04+05))+06+07+08)×09):10

01 - Valor da unidade tratora

02 - Quantidade de pneus - unidade tratora

03 - Valor do pneu - unidade tratora

04 - Valor da câmara - unidade tratora

05 - Valor do protetor - unidade tratora

06 - Valor do basculante

07 - Valor do $3^{\circ}$ eixo s/pneus

08 - Rodoar

09 - Taxa sobre peças, acessórios mat. de manutenção

10 - Quilometragem percorrida mensalmente

b - Combustível: (01:02)

$292.600,00$

10,00

$1.229,97$
73,41

39,31

$40.000,00$

0,00
863,00

0,01

$20.000,00$

01 - Preço do combustível por litro

02 - Rendimento do combustível

1,39

2,50

C - Lubrificantes: $((01 \times(02+03)): 04)+((05 \times 06): 07)$

01 - Preço do óleo de cárter $\mathrm{p} /$ litro

02 - Capacidade de óleo do cárter

03 - Reposição até a próximo troca

04 - Troca de óleo do cárter

05 - Preço do óleo de câmbio/diferencial p/ litro

06 - Capacidade de óleo do diferencial

07 - Troca de óleo do diferencial

d - Lavagem e lubrificação: (01:02)

01 - Preço de lavagem da composição

02 - Periodicidade de lavagem da composição

e - Pneus: $((01+02+03) \times 05 \times 06)+(08 \times 04 \times 05)): 07$

01 - Valor do pneu

02 - Valor da câmara

03 - Valor do protetor

04 - Valor da recauchutagem

05 - Quantidades de pneus - unidade tratora mais basculante

06 - Perda de pneu novo

07 - Vida útil do pneu

08 - Número de recapagens
0,01

0,22 


\section{CUSTOS OPERACIONAIS RODOVIÁRIOS PARA O TRANSPORTE DE AÇÚCAR TIPO EXPORTAÇÃO}

$\begin{array}{ll}\text { CUSTOS OPERACIONAIS } & \\ \text { Tipo de Carga: } & \text { Açúcar a granel } \\ \text { Tipo de Veículo: } & \text { VOLVO FH12 6X4 420 } \\ \text { Implemento } & \text { Bitrem graneleiro 4 eixo } \\ \text { KMIMÊS: } & 20.000\end{array}$

$1 / 6 / 2004$

Dados de entrada:

02 - Valor da unidade tratora

03 - Valor do implemento bitrem sem pneus

04 - Valor do $3^{\circ}$ eixo $s /$ pneus

05 - Rodoar

07 - Taxa para Licenciamento

07 - Taxa para

09 - Valor do estepe - unidade tratora

10 - Valor do pneu - 1100/22 R- unidade tratora

11 - Valor da câmara - unidade tratora

12- Valor do protetor - unidade tratora
13 - Valor da recapagem a frio - unidade tratora

13- Valor da recapagem a frio - unidade trat

15 - Valor do estepe - implemento bitrem

16- Valor da recauchutagem - implemento bitrem

17 - Quantidade pneus - implemento bitrem

18 - Salário do motorista $(1,4 \times$ piso $S P)$

19 - Salário do mecânico - Dissíd.Colet.

20 - Preço combustível p/litro - diesel

21 - Preço óleo do cárter p/litro

22 - Preço óleo câmbio/diferencial p/litro

23 - Preço lavagem da composição

24 - Taxa de remuneração do capital da composição (a.a)

25 - Taxa de remuneração de peças (a.a)

26 - Taxas sobre peças, aces. e mat.manutenção

27 - Encargos Sociais

28 - Quant.veículos atendidos por mecânico

29 - Taxa de depreciação da unidade tratora

30 - Vida útil da unidade tratora

31 - Vida útil do implemento bitrem
32 - Taxa de depreciação da unidade rebocada

33 - Coeficiente sobre importância segurada

34 - Custo da apólice

35 - Imposto sobre Operações Financeiras

36 - Coeficiente sobre importância segurada

37 - S.R.C.F. Prêmio de DM (R\$50 mil)/DP(R\$100 mil)

38 - Quilometragem percorrida mensalmente

39 - Rendimento do combustível

40 - Capacidade de óleo do cárter

41 - Reposição até a próxima troca

42 - Troca de óleo do cárter

43 - Capacidade de óleo caixa diferencia

44 - Troca de óleo diferencial

45 - Periodiocidade lavagem da composição

46 - Perda do pneu novo

47 - Vida útil do pneu com duas recapagens

48 - Equipamento de monitoramento por satélite

49 - Operação de monitoramento por satélite

50 - Seguro da carga (açúcar a granel)

51 - Índice de despesas indiretas (em relação ao custo total operacional)

52 - Índice de despesas diretas (em relação ao custo total operacional)

Resumo dos Custos (A, B e C)

A - Custos Fixos Mensais : $(a+b+c+d+e+f+g+h+i+j+l)$

$15.135,37$

$4.786,62$

$2.030,96$

660,06

$2.016,01$

214,20

451,77

$3.292,38$

746,33

111,67

500,00

325,37

I- Sistema de monitoramento por satélite

B - Custos Variáveis: $(a+b+c+d+e)$

a - Peças, acessórios e materiais de manutenção

c - Lubrificantes

d - Lavagem e lubrificação 
a - Remuneração de Capital da composição [(11)+ (13)]:12

$4.786,62$

01 - Valor da unidade tratora

02 - Rodoar

03 - Valor do implemento bitrem

04 - Valor do $3^{\circ}$ eixo s/pneus

05 - Quantidade de pneus - implemento bitrem

06 - Valor do pneu do implemento bitrem

07 - Valor da câmara do implemento bitrem

08 - Valor do protetor do implemento bitrem
09 - Valor Total $(01+02+03+04+(05 x(06+07+08))$

10 - Taxa de remuneração do capital da composição (a.a)

11 - Valor anual da remuneração do capital

12 - Taxa de remuneração de peças (a.a)

13 - Valor anual de remuneração de peças - $(09 \times 12)$

$2.030,96$

b - Salário do motorista: (01×02)

01 - Salário do motorista

02 - Encargos Sociais sobre salário do motorista

c-

02 - Quantidade de veículos atendido $p /$ mecânico

03 - Encargo sociais sobre salário do mecânico

d - Depreciação da unidade tratora: ((01-(02×(03+04+05))+06+07) x08):09

01 - Valor da unidade tratora

02 - Quantidade de pneus - unidade tratora

03 - Valor do pneu - unidade tratora

04 - Valor da câmara - unidade tratora

06 - Valor do $3^{\circ}$ eixo $\mathrm{s} /$ pneus

07 - Rodoar

08 - Taxa de depreciação da unidade tratora

08 - Taxa de depreciação da unida útil da unidade tratora

e - Depreciação do implemento bitrem: (01×02):03

01 - Valor do implemento bitrem

02 - Taxa de depreciaçào implemento bitrem

03 - Vida útil do implemento bitrem

f - Licenciamento: (01+02+03):12 meses

01 - DEPVAT

02 - I.P.V.A

03 - Taxa para licenciamento

g - Seguro casco da unidade tratora: [05x(01+02)+03])x04):12 meses

01 - Valor da unidade tratora

02 - Rodoar

03 - Custo da apólice

03 - Custo da apólice

04 - Coeficiente sobre importância segurada

h - Seguro casco do implemento bitrem: [05x(01+02)+03] x04:12 meses

01 - Valor do implemento bitrem sem pneus

02 - Pneus do implemento bitrem

03 - Custo da apólice

04 - Imposto sobre Operações Financeiras - IOF

05 - Coeficiente sobre importância segurada

i - Seguro Responsabilidade Civil Facultativo:(01+02):12 meses

01 - S.R.C.F. prêmio danos materiais e pessoais (corporais)

02 - Imposto sobre Operações Financeiras- IOF

j - Seguro de carga (açúcar a granel) - valor mensal: 01

01 - Apólice e impostos atribuidos

I- Sistema de monitoramento por satélite: ((01:03)+02) - valor mensal 
a - Peças, acessórios e materiais de manutenção (((01-(02×(03+04+05))+06+07+08)×09):10

0,20

01 - Valor da unidade tratora

02 - Quantidade de pneus - unidade tratora

03 - Valor do pneu - unidade tratora

04 - Valor da câmara - unidade tratora

05 - Valor do protetor - unidade tratora
06 - Valor do implemento bitrem sem pneus

07 - Valor do $3^{\circ}$ eixo s/pneus

08 - Rodoar

09 - Taxa sobre peças, acessórios mat. de manutenção

10 - Quilometragem percorrida mensalmente

b - Combustível: (01:02)

01 - Preço do combustível por litro

02 - Rendimento do combustível

C - Lubrificantes: ((01×(02+03)):04)+((05×06) : 07)

01 - Preço do óleo de cárter $\mathrm{p} /$ litro

02 - Capacidade de óleo do cárter

03 - Reposição até a próximo troc

04 - Troca de óleo do cárter

05 - Preço do óleo de câmbio/diferencial p/ litro

06 - Capacidade de óleo do diferencial

07 - Troca de óleo do diferencial

d - Lavagem e lubrificação: (01:02)

01 - Preço de lavagem da composição

02 - Periodicidade de lavagem da composição

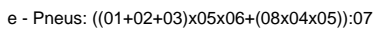

01 - Valor do pneu

02 - Valor da câmara

03 - Valor do protetor

04 - Valor da recauchutagem

05 - Quantidades de pneus - unidade tratora mais implemneto bitrem

06 - Perda de pneu novo

07 - Vida útil do pneu

08 - Número de recapagens
$357.039,06$ 10,00 1117,25 39,31 $64.260,00$

0,00
863,00

863,00
0,01

$20.000,00$

$30.000,00$
6,95

6,95
65,00

$120.000,00$

170,00
$4.000,00$

0,26

$1.117,25$

73,41

39,31
245,00

26,00

$200.000,00$

2,00 


\section{CUSTOS OPERACIONAIS RODOVIÁRIOS PARA \\ O TRANSPORTE DE AÇÚCAR TIPO EXPORTAÇÃO}

$\begin{array}{ll}\text { CUSTOS OPERACIONAIS } & \\ \text { Tipo de Carga: } & \text { Açúcar a granel } \\ \text { Tipo de Veículo: } & \text { VOLVO FH12 6X4 420 } \\ \text { Implemento } & \text { Bitrem graneleiro } 6 \text { eixo } \\ \text { KM/MÊS: } & 20.000\end{array}$

Data:

$1 / 6 / 2004$

Dados de entrada:

02 - Valor da unidade tratora

03 - Valor do implemento bitrem sem pneus

04 - Valor do $3^{\circ}$ eixo s/ pneus

05 - Rodoar

06 - I.P.V.A

07 - Taxa para Licenciamento

08 - DEPVAT

09 - Valor do estepe - unidade tratora

10 - Valor do pneu - 1100/22 R- unidade tratora

11 - Valor da câmara - unidade tratora

12. Valor do protetor - unidade tratora

13 - Valor da recapagem a frio - unidade tratora

14 - Quantidade de pneus - unidade tratora

15 - Valor do estepe - implemento bitrem

16 - Valor da recauchutagem - implemento bitrem

17 - Quantidade pneus - implemento bitrem

18 - Salário do motorista (1,4 $\times$ piso $\mathrm{SP})$

19 - Salário do mecânico - Dissíd.Colet.

20 - Preço combustível p/litro - diesel

21 - Preço óleo do cárter p/litro

22 - Preço óleo câmbio/diferencial p/litro

23 - Preço lavagem da composição

24 - Taxa de remuneração do capital da composição (a.a)

25 - Taxa de remuneração de peças (a.a)

26 - Taxas sobre peças, aces. e mat.manutenção

27 - Encargos Sociais

28 - Quant.veículos atendidos por mecânico

29 - Taxa de depreciação da unidade tratora

30 - Vida útil da unidade tratora

31 - Vida útil do implemento bitrem

32 - Taxa de depreciação da unidade rebocada

33 - Coeficiente sobre importância segurada

34 - Custo da apólice

35 - Imposto sobre Operações Financeiras

36 - Coeficiente sobre importância segurada

37 - S.R.C.F. Prêmio de DM (R\$50 mil)/DP(R\$100 mil)

38 - Quilometragem percorrida mensalmente

39 - Rendimento do combustível

40 - Capacidade de óleo do cárter

41 - Reposição até a próxima troca

42 - Troca de óleo do cárter

43 - Capacidade de óleo caixa diferencial

44 - Troca de óleo diferencial

45 - Periodiocidade lavagem da composição

46 - Perda do pneu novo

47 - Vida útil do pneu com duas recapagens

48 - Autorização Especial de Trânsito

49 - Equipamento de monitoramento por satélite

50 - Operação de monitormente por satélite

51 - Seguro de carga (açúcar a granel)

52 - Índice de despesas indiretas (em relação ao custo total operacional)

53 - índice de despesas diretas (em relação ao custo total operacional)

Resumo dos Custos (A, B e C)

A - Custos Fixos Mensais : $(a+b+c+d+e+f+g+h+i+j+l+m)$

a - Remuneração de capital da composição

$5.241,29$

b - Salário do motorista

c - Salário de oficina

d - Depreciação da unidade tratora

e - Depreciação do implemento bitrem

$\mathrm{f}$ - Licenciamento

$357.039,06$

$0.390,00$

863,00

$5.355,59$

10,20
55,43
$1.229,97$

$.229,97$
111,25

$-117,25$
73,41

39,31

245,00

$1.229,97$

245,00
24,00

$.034,78$
24,00

840,76

1,39
5,71

170,00

0,12

0,01

1,96
2,50
0,70

meses

120,00

mese

$\mathrm{R} \$$

$\mathrm{R} \$$ /ano

$1.252,34$

$20.000,00$

I- Sistema de monitoramento por satélite

m - Autorização Especial de Trânsito

B - Custos Variáveis: $(a+b+c+d+e)$

2.030,96

660,06

$2.016,01$

321,30

451,77

$3.292,38$

$1.116,81$

111,67

500,00

325,37

a - Peças, acessórios e materiais de manutenção 
03 - Valor do implemento bitrem

04 - Valor do $3^{\circ}$ eixo s/pneus

05 - Quantidade de pneus - implemento bitrem

06 - Valor do pneu do implemento bitrem

07 - Valor da câmara do implemento bitrem

08 - Valor do protetor do implemento bitrem

09 - Valor Total $(01+02+03+04+(05 \times(06+07+08)))$

10 - Taxa de remuneração do capital da composição (a.a)

11 - Valor anual da remuneração do capital

12 - Taxa de remuneração de peças (a.a)

b - Salário do motorista: (01×02)

01 - Salário do mecânico - média

02 - Quantidade de veículos atendido p/ mecânico

03 - Encargo sociais sobre salário do mecânico

$2.016,01$

d - Depreciação da unidade tratora: ((01-(02×(03+04+05))+06+07) ×08):09

01 - Valor da unidade tratora

02 - Quantidade de pneus - unidade tratora

03 - Valor do pneu - unidade tratora

04 - Valor da câmara - unidade tratora

05 - Valor do protetor - unidade tratora

06 - Valor do

07 - Rodoar
08 - Taxa de depreciação da unidade tratora

09 - Vida útil da unidade tratora

e - Depreciação do implemento bitrem: (01×02):03

01 - Valor do implemento bitrem

02 - Taxa de depreciaçào implemento bitrem

03 - Vida útil do implemento bitrem

f - Licenciamento: (01+02+03):12 meses

03 - Taxa para licenciamento

$\mathrm{g}$ - Seguro casco da unidade tratora: $[05 \times(01+02)+03]) \times 04): 12$ meses

04 - Imposto sobre Operações Financeiras - IOF

05 - Coeficiente sobre importância segurada

h - Seguro casco do implemento bitrem: [05x(01+02)+03] x04:12 meses

01 - Valor do implemento bitrem sem pneus

02 - Pneus do implemento bitrem

03 - Custo da apólice

04 - Imposto sobre Operações Financeiras - IOF

05 - Coeficiente sobre importância segurada

60,00

1,07

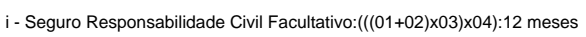


01 - Equipamentos de monitoramento

02 - Operação de monitoramento - valor mensal

02 - Operação de monitoramento -

$10.844,00$

235,00

m - Autorização Especial de Trânsito-AET: 01:12 meses

01 - Valor da licença anual (DER-SP)

90,00

B - Custos Variáveis por KM: $(a+b+c+d+e)$

a - Peças, acessórios e materiais de manutenção (((01-(02x(03+04+05))+06+07+08)x09):10

01 - Valor da unidade tratora

$357.039,06$

02 - Quantidade de pneus - unidade trator

03 - Valor do pneu - unidade tratora

04 - Valor da câmara - unidade tratora

05 - Valor do protetor - unidade tratora

06 - Valor do implemento bitrem sem pneus

07 - Valor do $3^{\circ}$ eixo s/pneus

08 - Rodoar

09 - Taxa sobre peças, acessórios mat. de manutenção

10 - Quilometragem percorrida mensalmente

b - Combustível: (01:02)

$$
\begin{array}{r}
357.039,06 \\
10,00 \\
1.229,97 \\
73,41 \\
39,31 \\
96.390,00 \\
0,00 \\
863,00 \\
0,01 \\
20.000,00
\end{array}
$$

01 - Preço do combustível por litro

02 - Rendimento do combustível

1,39

2,00

C - Lubrificantes: $((01 \times(02+03)): 04)+((05 \times 06): 07)$

01 - Preço do óleo de cárter p/ litro

02 - Capacidade de óleo do cárter

03 - Reposição até a próximo troca

04 - Troca de óleo do cárter

05 - Preço do óleo de câmbio/diferencial p/ litro

06 - Capacidade de óleo do diferencial

07 - Troca de óleo do diferencial

01 - Preço de lavagem da composição

02 - Periodicidade de lavagem da composição

70,00

$4.000,00$

e - Pneus: $((01+02+03) \times 05 \times 06+(08 \times 04 \times 05)): 07$

01 - Valor do pneu

02 - Valor da câmara

03 - Valor do protetor

04 - Valor da recauchutagem

05 - Quantidades de pneus - unidade tratora mais implemneto bitrem

06 - Perda de pneu novo

08 - Número de recapagens 
APÊNDICE F

ÍNDICES DE DESPESAS INDIRETAS 
Prezado Vitor;

O sistema adotado pela NTC e pela Fipe é o de ratear as despesas administrativas pela tonelagem transportada. Utiliza-se a tonelagem como direcionador (driver) de custos, para usar a moderna terminologia do custeio baseado em atividade (custeio ABC ou Activity Based Cost). Considera-se que estas despesas independem do percurso. No caso da lotação, este custo era em janeiro de 2005 de R\$ 9,02 por tonelada (arquivo anexo). Isso, num custo total (já incluida esta despesa) por tonelada transportada que varia entre $\mathrm{R} \$ 34,14$ para $50 \mathrm{~km}$ e $\mathrm{R} \$$ 543,34 para $6.000 \mathrm{~km}$. No percurso considerado médio (800 km), o custo é de R\$101,82. O percentual, obviamente reduz-se drasticamente à medida que o percurso aumenta.

O Professor Maurício Lima, do Coppead, trabalha com um valor constante adicionado ao custo fixo mensal do veículo, conforme você pode ver no artigo anexo. Ou seja, usa como direcionador (divisor) o número de veículos. Adotamos procedimento similar em nossa planilha de carga líquida (anexa).

Não temos nenhuma planilha onde tenhamos adotado percentual do custo total para as despesas administrativas. Mas cheguei a levantar isso para carga frigorífica. As empresas mais eficientes conseguiam trabalhar com $12 \%$ sobre o custo. Mas havia algumas onde este percentual dobrava.

Fico ao seu dispor para qualquer esclarecimento adicional.

Abraços,

Neuto

----- Original Message -----

From: "Vitor Borges da Silva" <vborges@sc.usp.br>

To: "Decope" <ngreis@ntc.org.br>

Sent: Wednesday, February 02, 2005 4:14 PM

Subject: Informação_USP São Carlos

Boa tarde Neuto,

Mais uma vez quem escreve é o Vitor, orientado do professor Widmer. Neuto, estou na fase de conclusão de minha dissertação e o Widmer pediu para que eu entrasse em contato com você para conseguir uma informação.

Em nosso modelo de custos rodoviários, adotamos uma parcela de $12 \%$ dos custos totais relativos aos custos indiretos de administração. Segundo o cenário que estamos avaliando (transporte de açúcar a granel), o qual o professor presta serviços de consultoria para algumas usinas, esse valor pode ser considerado razoável para adoção. Até porque, por se tratarem de várias usinas, seria muito difícil levantar esse valor com exatidão, além de não ser esse nosso objetivo. 
No entanto, falta-nos uma referência de algum trabalho que já tenha utilizado valores de custos indiretos dessa ordem. Ou se por acaso for de ordem de grandeza diferente, pelo menos eu tenho uma fonte para balizar minha adoção.

Será que você teria algum trabalho aí da NTC o qual eu possa utilizar como

referência para esse meu critério de adoção?

Desde já agradeço a ajuda.

Obrigado,

Eng. Vitor Borges da Silva

tel.: (16) 3376-9915

(16)9701-9425

(16)3373-9613

e-mail: vborges@sc.usp.br

A seguir, trecho destacado por Neuto Gonçalves dos Reis em anexo ao e-mail anterior.

\section{O Custeio do Transporte Rodoviário}

\section{Maurício Pimenta Lima}

$(\ldots)$

Os custos administrativos merecem um cuidado especial, pois são custos indiretos em relação ao veículo, e portanto, precisarão ser rateados. Assim, a empresa deve aplicar o critério de rateio que parecer mais justo. O mais simples a ser feito é dividir o custo administrativo mensal pelo número de veículos, que para grande maioria das situações é uma fórmula bastante justa. É importante tomar cuidado ao utilizar a informação desse item de custo para apoiar determinadas decisões, pois o fato dele ser rateado por veículo não garante que este seja eliminado, ou mesmo reduzido, caso se diminua o tamanho da frota.

$(\ldots)$ 
CUSTOS DO TRANSPORTE RODOVIÁRIO DE CARGA LOTAÇÃO

VARIAÇÃO MENSAL DOS CUSTOS

\begin{tabular}{|c|c|c|c|c|c|c|c|}
\hline \multirow{2}{*}{$\begin{array}{l}\text { TARIFA } \\
\text { NÚMERO }\end{array}$} & \multirow{2}{*}{\multicolumn{3}{|c|}{$\begin{array}{c}\text { CLASSES DE PERCURSO } \\
(\mathrm{km})\end{array}$}} & \multicolumn{2}{|c|}{ CUSTO TOTAL (R\$/t) } & \multirow{2}{*}{$\begin{array}{l}\text { VARIAÇÃO \% } \\
\text { MENSAL } \\
\end{array}$} & \multirow[b]{2}{*}{ DISTÂNCIAS } \\
\hline & & & & JANEIRO/05 & DEZEMBRO/04 & & \\
\hline 1 & 1 & $\bar{a}$ & 50 & 34.14 & 34.00 & $0.41 \%$ & Muito Curtas \\
\hline 5 & 51 & a & 100 & 38.31 & 38.14 & $0.43 \%$ & \\
\hline 10 & 101 & a & 150 & 42.47 & 42.28 & $0.45 \%$ & \\
\hline 15 & 151 & a & 200 & 46.63 & 46.41 & $0.47 \%$ & \\
\hline 20 & 201 & a & 250 & 50.78 & 50.54 & $0.48 \%$ & \\
\hline 25 & 251 & a & 300 & 56.73 & 56.45 & $0.49 \%$ & \\
\hline 30 & 301 & a & 350 & 60.88 & 60.58 & $0.50 \%$ & \\
\hline 35 & 351 & a & 400 & 65.03 & 64.70 & $0.51 \%$ & Curtas \\
\hline 40 & 401 & a & 450 & 69.18 & 68.83 & $0.52 \%$ & \\
\hline 45 & 451 & $a$ & 500 & 73.33 & 72.95 & $0.52 \%$ & \\
\hline 50 & 501 & $\mathrm{a}$ & 550 & 81.08 & 80.66 & $0.53 \%$ & \\
\hline 55 & 551 & a & 600 & 85.23 & 84.78 & $0.53 \%$ & \\
\hline 60 & 601 & $\mathrm{a}$ & 650 & 89.38 & 88.90 & $0.53 \%$ & \\
\hline 65 & 651 & $a$ & 700 & 93.53 & 93.03 & $0.54 \%$ & \\
\hline 70 & 701 & $\mathrm{a}$ & 750 & 97.67 & 97.15 & $0.54 \%$ & \\
\hline 75 & 751 & $\mathbf{a}$ & 800 & 101.82 & 101.27 & $0.55 \%$ & Médias - INCT-L \\
\hline 80 & 801 & $\mathrm{a}$ & 850 & 105.97 & 105.39 & $0.55 \%$ & \\
\hline 85 & 851 & $a$ & 900 & 110.11 & 109.51 & $0.55 \%$ & \\
\hline 90 & 901 & $\mathrm{a}$ & 950 & 114.26 & 113.63 & $0.55 \%$ & \\
\hline 95 & 951 & $a$ & 1000 & 118.40 & 117.75 & $0.56 \%$ & \\
\hline 100 & 1001 & a & 1100 & 128.50 & 127.78 & $0.56 \%$ & \\
\hline 110 & 1101 & $a$ & 1200 & 136.79 & 136.02 & $0.56 \%$ & \\
\hline 120 & 1201 & $\mathrm{a}$ & 1300 & 145.08 & 144.26 & $0.57 \%$ & \\
\hline 130 & 1301 & $\mathrm{a}$ & 1400 & 153.36 & 152.49 & $0.57 \%$ & \\
\hline 140 & 1401 & $\mathrm{a}$ & 1500 & 161.65 & 160.73 & $0.57 \%$ & \\
\hline
\end{tabular}




\begin{tabular}{|c|c|c|c|c|c|c|c|}
\hline 150 & 1501 & a & 1600 & 171.75 & 170.76 & $0.57 \%$ & \\
\hline 160 & 1601 & a & 1700 & 180.03 & 179.00 & $0.58 \%$ & \\
\hline 170 & 1701 & a & 1800 & 188.32 & 187.23 & $0.58 \%$ & \\
\hline 180 & 1801 & a & 1900 & 196.60 & 195.46 & $0.58 \%$ & \\
\hline 190 & 1901 & a & 2000 & 204.88 & 203.70 & $0.58 \%$ & \\
\hline 200 & 2001 & a & 2200 & 223.27 & 221.97 & $0.59 \%$ & \\
\hline 220 & 2201 & a & 2400 & 239.83 & 238.43 & $0.59 \%$ & Longas \\
\hline 240 & 2401 & a & 2600 & 256.40 & 254.90 & $0.59 \%$ & \\
\hline 260 & 2601 & a & 2800 & 274.78 & 273.17 & $0.59 \%$ & \\
\hline 280 & 2801 & a & 3000 & 291.35 & 289.63 & $0.59 \%$ & \\
\hline 300 & 3001 & a & 3200 & 309.73 & 307.90 & $0.59 \%$ & \\
\hline 320 & 3201 & a & 3400 & 326.29 & 324.36 & $0.60 \%$ & \\
\hline 340 & 3401 & $a$ & 3600 & 344.68 & 342.63 & $0.60 \%$ & \\
\hline 360 & 3601 & a & 3800 & 361.24 & 359.09 & $0.60 \%$ & \\
\hline 380 & 3801 & $a$ & 4000 & 377.80 & 375.55 & $0.60 \%$ & \\
\hline 400 & 4001 & a & 4200 & 394.37 & 392.01 & $0.60 \%$ & \\
\hline 420 & 4201 & a & 4400 & 410.93 & 408.47 & $0.60 \%$ & \\
\hline 440 & 4401 & a & 4600 & 427.49 & 424.93 & $0.60 \%$ & \\
\hline 460 & 4601 & a & 4800 & 444.05 & 441.39 & $0.60 \%$ & \\
\hline 480 & 4801 & a & 5000 & 460.62 & 457.85 & $0.60 \%$ & \\
\hline 500 & 5001 & a & 5200 & 477.18 & 474.31 & $0.60 \%$ & \\
\hline 520 & 5201 & a & 5400 & 493.74 & 490.77 & $0.61 \%$ & \\
\hline 540 & 5401 & a & 5600 & 510.30 & 507.23 & $0.61 \%$ & \\
\hline 560 & 5601 & a & 5800 & 526.86 & 523.69 & $0.61 \%$ & \\
\hline 580 & 5801 & a & 6000 & 543.42 & 540.14 & $0.61 \%$ & Muito Longas \\
\hline
\end{tabular}


APÊNDICE G

RESUMOS DOS CUSTOS OPERACIONAIS RODOVIÁRIOS 
CUSTOS RODOVIÁRIOS DOS VEÍCULOS UTILIZADOS

PARA O TRANSPORTE DE AÇÚCAR TIPO EXPORTAÇÃO

\begin{tabular}{|c|c|c|c|c|}
\hline Custos apurados em 01/06/2004 & $\begin{array}{l}\text { Composição } \\
\text { Bitrem } 7 \text { eixos }\end{array}$ & $\begin{array}{l}\text { Composição } \\
\text { Bitrem } 9 \text { eixos }\end{array}$ & $\begin{array}{c}\text { Composição } \\
\text { Basculante } 6 \text { eixos }\end{array}$ & $\begin{array}{c}\text { Composição } \\
\text { Graneleira } 5 \text { eixos }\end{array}$ \\
\hline \multicolumn{5}{|l|}{ 1.) CUSTO MENSAL EM VALOR ABSOLUTO (R\$) } \\
\hline CUSTO FIXO & $15.135,37$ & $16.075,13$ & $12.734,45$ & $12.139,49$ \\
\hline a - Remuneração de capital da composição & $4.786,62$ & $5.241,29$ & $3.772,41$ & $3.568,75$ \\
\hline b - Salário do motorista & $2.030,96$ & $2.030,96$ & $2.030,96$ & $2.030,96$ \\
\hline C - Salário de oficina & 660,06 & 660,06 & 660,06 & 660,06 \\
\hline d - Depreciação da unidade tratora & $2.016,01$ & $2.016,01$ & $1.640,12$ & $1.543,29$ \\
\hline e - Depreciação do implemento & 214,20 & 321,30 & 133,33 & 31,50 \\
\hline$f$ - Licenciamento & 451,77 & 451,77 & 371,22 & 350,47 \\
\hline g- Seguro do casco da unidade tratora & $3.292,38$ & $3.292,38$ & $2.700,56$ & $2.548,11$ \\
\hline h - Seguro do implemento & 746,33 & $1.116,81$ & 488,74 & 469,32 \\
\hline i - Seguro de responsabilidade civil facultativo & 111,67 & 111,67 & 111,67 & 111,67 \\
\hline j - Seguro da carga (açúcar granel) & 500,00 & 500,00 & 500,00 & 500,00 \\
\hline I - Sistema de monitoramento por satélite & 325,37 & 325,37 & 325,37 & 325,37 \\
\hline m - Autorização Especial de Trânsito & 0,00 & 7,50 & 0,00 & 0,00 \\
\hline CUSTO VARIÁVEL - para $15.000 \mathrm{~km}$ & $18.233,07$ & $20.691,80$ & $15.576,63$ & $15.388,63$ \\
\hline a - Peças, acessórios e materiais de manutenção & $4.098,62$ & $4.408,65$ & $3.200,36$ & $3.012,36$ \\
\hline b - Combustiveis & $9.497,73$ & $10.447,50$ & $8.358,00$ & $8.358,00$ \\
\hline c- Lubrificantes & 165,59 & 184,94 & 136,93 & 136,93 \\
\hline d - Lavagem e lubrificação & 637,50 & 637,50 & 637,50 & 637,50 \\
\hline e - Pneus & $3.833,63$ & $5.013,21$ & $3.243,84$ & $3.243,84$ \\
\hline CUSTO ADMINISTRATIVO & $4.550,24$ & $5.013,67$ & $3.860,60$ & $3.753,83$ \\
\hline \multicolumn{5}{|l|}{ 2.) CUSTO MENSAL POR KM (R\$/KM) } \\
\hline Quilometragem Mensal & $15.000,00$ & $15.000,00$ & $15.000,00$ & $15.000,00$ \\
\hline CUSTO FIXO & 1,01 & 1,07 & 0,85 & 0,81 \\
\hline CUSTO VARIÁVEL & 1,22 & 1,38 & 1,04 & 1,03 \\
\hline CUSTO ADMINISTRATIVO & 0,30 & 0,33 & 0,26 & 0,25 \\
\hline \multicolumn{5}{|l|}{ 3.) CUSTO TOTAL MENSAL } \\
\hline ABSOLUTO (R\$) & $37.918,68$ & $41.780,60$ & $32.171,68$ & $31.281,95$ \\
\hline POR KM (RS/KM) & 2,53 & 2,79 & 2,14 & 2,09 \\
\hline
\end{tabular}




\section{CUSTOS RODOVIÁRIOS DOS VEÍCULOS UTILIZADOS}

\section{PARA O TRANSPORTE DE AÇÚCAR TIPO EXPORTAÇÃO}

\begin{tabular}{|c|c|c|c|c|}
\hline Custos apurados em 01/06/2004 & $\begin{array}{l}\text { Composição } \\
\text { Bitrem } 7 \text { eixos }\end{array}$ & $\begin{array}{l}\text { Composição } \\
\text { Bitrem } 9 \text { eixos }\end{array}$ & $\begin{array}{c}\text { Composição } \\
\text { Basculante } 6 \text { eixos }\end{array}$ & $\begin{array}{c}\text { Composição } \\
\text { Graneleira } 5 \text { eixos }\end{array}$ \\
\hline \multicolumn{5}{|l|}{ 1.) CUSTO MENSAL EM VALOR ABSOLUTO (R\$) } \\
\hline CUSTO FIXO & $15.135,37$ & $16.075,13$ & $12.734,45$ & $12.139,49$ \\
\hline a - Remuneração de capital da composição & $4.786,62$ & $5.241,29$ & $3.772,41$ & $3.568,75$ \\
\hline b - Salário do motorista & $2.030,96$ & $2.030,96$ & $2.030,96$ & $2.030,96$ \\
\hline c - Salário de oficina & 660,06 & 660,06 & 660,06 & 660,06 \\
\hline d - Depreciação da unidade tratora & $2.016,01$ & $2.016,01$ & $1.640,12$ & $1.543,29$ \\
\hline e - Depreciação do implemento & 214,20 & 321,30 & 133,33 & 31,50 \\
\hline f - Licenciamento & 451,77 & 451,77 & 371,22 & 350,47 \\
\hline g - Seguro do casco da unidade tratora & $3.292,38$ & $3.292,38$ & $2.700,56$ & $2.548,11$ \\
\hline h - Seguro do implemento & 746,33 & $1.116,81$ & 488,74 & 469,32 \\
\hline i - Seguro de responsabilidade civil facultativo & 111,67 & 111,67 & 111,67 & 111,67 \\
\hline j - Seguro da carga (açúcar granel) & 500,00 & 500,00 & 500,00 & 500,00 \\
\hline I - Sistema de monitoramento por satélite & 325,37 & 325,37 & 325,37 & 325,37 \\
\hline m - Autorização Especial de Trânsito & 0,00 & 7,50 & 0,00 & 0,00 \\
\hline CUSTO VARIÁVEL - para $20.000 \mathrm{~km}$ & $22.944,56$ & $26.119,52$ & $19.702,05$ & $19.514,05$ \\
\hline a - Peças, acessórios e materiais de manutenção & $4.098,62$ & $4.408,65$ & $3.200,36$ & $3.012,36$ \\
\hline b - Combustíveis & $12.663,64$ & $13.930,00$ & $11.144,00$ & $11.144,00$ \\
\hline c - Lubrificantes & 220,79 & 246,59 & 182,57 & 182,57 \\
\hline d - Lavagem e lubrificação & 850,00 & 850,00 & 850,00 & 850,00 \\
\hline e - Pneus & $5.111,51$ & $6.684,28$ & $4.325,12$ & $4.325,12$ \\
\hline CUSTO ADMINISTRATIVO & $5.192,72$ & $5.753,82$ & $4.423,16$ & $4.316,39$ \\
\hline \multicolumn{5}{|l|}{ 2.) CUSTO MENSAL POR KM (R\$/KM) } \\
\hline Quilometragem Mensal & $20.000,00$ & $20.000,00$ & $20.000,00$ & $20.000,00$ \\
\hline CUSTO FIXO & 0,76 & 0,80 & 0,64 & 0,61 \\
\hline CUSTO VARIÁVEL & 1,15 & 1,31 & 0,99 & 0,98 \\
\hline CUSTO ADMINISTRATIVO & 0,26 & 0,29 & 0,22 & 0,22 \\
\hline \multicolumn{5}{|l|}{ 3.) CUSTO TOTAL MENSAL } \\
\hline ABSOLUTO (R\$) & $43.272,64$ & $47.948,46$ & $36.859,65$ & $35.969,93$ \\
\hline POR KM (R\$/KM) & 2,16 & 2,40 & 1,84 & 1,80 \\
\hline
\end{tabular}


APÊNDICE H

VALORES DOS FRETES NAS PONTAS RODOVIÁRIAS 
Fretes rodoviários nos ciclos usina-terminal-usina (pontas)

\begin{tabular}{cccc}
\hline Usina de origem & $\begin{array}{c}\text { Terminal de } \\
\text { destino }\end{array}$ & $\begin{array}{c}\text { Comp. do arco } \\
\mathbf{( k m )}\end{array}$ & Frete (R\$/ton) \\
\hline Usina $1(*)$ & S.J. Barra & 16,6 & 4,35 \\
\hline Usina $3(* *)$ & S.J. Barra & 52,5 & 7,80 \\
\hline Usina 5 & S.J. Barra & 75,0 & 8,00 \\
\hline Usina $7(* *)$ & S.J. Barra & 43,2 & 7,45 \\
\hline
\end{tabular}

\begin{tabular}{clcc}
\hline Usina de origem & $\begin{array}{c}\text { Terminal de } \\
\text { destino }\end{array}$ & $\begin{array}{c}\text { Comp. do arco } \\
(\mathbf{k m})\end{array}$ & Frete (R\$/ton) \\
\hline Usina 1 & Ribeirão Preto & 74,1 & 13,00 \\
\hline Usina 2 & Ribeirão Preto & 51,6 & 9,00 \\
\hline Usina 3 & Ribeirão Preto & 94,1 & 14,00 \\
\hline Usina 7 $(* * *)$ & Ribeirão Preto & 30,8 & 5,75 \\
\hline Usina 8 $(* *)$ & Ribeirão Preto & 256,7 & 38,00 \\
\hline
\end{tabular}

\begin{tabular}{cccc}
\hline Usina de origem & $\begin{array}{c}\text { Terminal de } \\
\text { destino }\end{array}$ & $\begin{array}{c}\text { Comp. do arco } \\
\mathbf{( k m )}\end{array}$ & Frete (R\$/ton) \\
\hline Usina 4 & Eng. Schmidt & 98,9 & 12,00 \\
\hline Usina 6 $\left(^{* *}\right)$ & Eng. Schmidt & 194,9 & 23,65 \\
\hline
\end{tabular}

(*) média aritmética entre dois valores: 3,70 R\$/ton e 5,00 R\$/ton.

$(* *)$ estimativa a partir de outros fretes cobrados e a distância da usina ao terminal.

$(* * *)$ média aritmética entre dois valores: 6,50 R\$/ton e 5,00 R\$/ton. 
APÊNDICE I

VALORES DOS FRETES RODOVIÁRIOS PORTA-A-PORTA 
FRETE RODOVIÁRIO NO CICLO USINA-PORTO-USINA (PORTA-A-PORTA)

\begin{tabular}{|c|c|c|c|c|c|c|c|c|c|c|c|}
\hline \multirow[b]{2}{*}{ USINA } & \multirow{2}{*}{$\begin{array}{l}\text { Arco } \\
\text { (km) }\end{array}$} & \multicolumn{2}{|c|}{ ABRIL } & \multicolumn{2}{|c|}{ MAIO } & \multicolumn{2}{|c|}{ JUNHO } & \multicolumn{2}{|c|}{ JULHO } & \multicolumn{2}{|c|}{ AGOSTO } \\
\hline & & Produção (t) & Frete $(\mathrm{R} \$ / \mathrm{t})$ & Produção (t) & Frete $(\mathrm{R} \$ / \mathrm{t})$ & Produção $(t)$ & Frete $(\mathrm{R} \$ / \mathrm{t})$ & Produção $(t)$ & Frete $(\mathrm{R} \$ / \mathrm{t})$ & Produção $(\mathrm{t})$ & Frete $(\mathrm{R} \$ / \mathrm{t})$ \\
\hline Usina 1 & 554,5 & 43.000 & 57,00 & 28.500 & 57,00 & 32.000 & 57,00 & 20.000 & 59,00 & 10.000 & 59,00 \\
\hline Usina 2 & 510,6 & 10.000 & 55,00 & 20.000 & 53,00 & 30.000 & 52,00 & 20.000 & 55,00 & 30.000 & 55,00 \\
\hline Usina 3 & 593,4 & 15.500 & 59,00 & 13.000 & 59,00 & 9.000 & 59,00 & 4.000 & 60,00 & 3.000 & 60,00 \\
\hline Usina 4 & 690,4 & 38.500 & 59,00 & 26.500 & 57,00 & 28.500 & 61,00 & 31.000 & 61,00 & 17.000 & 60,00 \\
\hline Usina 5 & 629,7 & 13.000 & 60,50 & 12.500 & 60,50 & 17.500 & 60,50 & 9.000 & 64,00 & 6.000 & 64,00 \\
\hline Usina 6 & 789,1 & 0 & 0,00 & 143 & 71,90 & 9.164 & 71,90 & 3.970 & 73,90 & 3.017 & 74,70 \\
\hline Usina 7 & 511,1 & 10.000 & 55,00 & 13.500 & 55,00 & 13.500 & 55,00 & 6.000 & 55,00 & 4.500 & 55,00 \\
\hline Usina 8 & 383,0 & 4.500 & 48,50 & 6.500 & 49,50 & 6.000 & 52,25 & 9.000 & 54,00 & 8.000 & 54,00 \\
\hline TOTAL & & 134.500 & & $120.643,00$ & & $145.664,00$ & & $102.970,00$ & & $81.517,00$ & \\
\hline
\end{tabular}

\begin{tabular}{|c|c|c|c|c|c|c|c|c|c|c|c|}
\hline \multirow[b]{2}{*}{ USINA } & \multirow{2}{*}{$\begin{array}{l}\text { Arco } \\
(\mathrm{km})\end{array}$} & \multicolumn{2}{|c|}{ SETEMBRO } & \multicolumn{2}{|c|}{ OUTUBRO } & \multicolumn{2}{|c|}{ NOVEMBRO } & \multicolumn{2}{|c|}{ DEZEMBRO } & \multicolumn{2}{|c|}{ JANEIRO } \\
\hline & & Produção (t) & Frete $(R \$ / t)$ & Produção (t) & Frete $(\mathrm{R} \$ / \mathrm{t})$ & Produção (t) & Frete $(\mathrm{R} \$ / \mathrm{t})$ & Produção (t) & Frete $(\mathrm{R} \$ / \mathrm{t})$ & Produção (t) & Frete $(\mathrm{R} \$ / \mathrm{t})$ \\
\hline Usina 1 & 554,5 & 15.000 & 59,00 & 18.000 & 59,00 & 15.000 & 56,00 & 31.500 & 56,00 & 2.000 & 56,00 \\
\hline Usina 2 & 510,6 & 20.000 & 57,00 & 30.000 & 57,00 & 20.000 & 53,00 & 0 & 53,00 & 0 & 53,00 \\
\hline Usina 3 & 593,4 & 4.500 & 60,00 & 4.500 & 60,00 & 3.000 & 57,00 & 8.000 & 57,00 & 2.000 & 57,00 \\
\hline Usina 4 & 690,4 & 11.000 & 62,00 & 16.500 & 81,00 & 11.000 & 63,00 & 23.500 & 59,00 & 2.000 & 55,00 \\
\hline Usina 5 & 629,7 & 10.000 & 64,00 & 14.500 & 64,00 & 11.500 & 61,00 & 15.000 & 61,00 & 1.000 & 61,00 \\
\hline Usina 6 & 789,1 & 1.669 & 78,00 & 1.527 & 78,70 & 2.477 & 78,20 & 8.173 & 71,00 & 1.133 & 77,50 \\
\hline Usina 7 & 511,1 & 5.000 & 55,00 & 7.500 & 55,00 & 6.500 & 52,00 & 12.000 & 52,00 & 1.000 & 52,00 \\
\hline Usina 8 & 383,0 & 8.500 & 54,00 & 5.500 & 52,50 & 5.000 & 51,00 & 9.000 & 51,00 & 1.000 & 51,00 \\
\hline TOTAL & & 75.669 & & 98.027 & & 74.477 & & 107.173 & & 10.133 & \\
\hline
\end{tabular}


APÊNDICE J

EXEMPLO DE PLANILHAS DE SIMULAÇÃO 
EXEMPLO CENÁRIO 1 - 3S3B3 - SAFRA 2004/2005

\section{TRANSPORTE RODOVIÁRIO PORTA-A-PORTA}

\begin{tabular}{|l|r|}
\hline Mês & Dezembro \\
\hline Composição & 3 S3B3 \\
\hline Lotação rodo. (ton) & 45 \\
\hline Rota & usina-porto-usina \\
\hline Frota & Própria \\
\hline
\end{tabular}

\begin{tabular}{|c|c|c|c|c|c|c|c|}
\hline Usina & $\begin{array}{l}\text { Produção } \\
\text { (ton) }\end{array}$ & $\begin{array}{l}\mathrm{N}^{\circ} \\
\text { viagens }\end{array}$ & $\begin{array}{l}\text { Comprimento } \\
\operatorname{Arco}(\mathrm{km})\end{array}$ & $\begin{array}{l}\text { Carregamento } \\
(\%)\end{array}$ & $\begin{array}{l}\text { Carregamento } \\
\text { (ton) }\end{array}$ & $\begin{array}{c}\text { Custo por viagem }(\mathrm{R} \$) \\
\text { TransCAD }\end{array}$ & $\begin{array}{c}\text { Custo Total } \\
\text { Rodoviário (R\$) }\end{array}$ \\
\hline Usina 1 & 31500 & 700 & 554,5 & 100 & 31500 & $2.869,67$ & $2.008 .769,00$ \\
\hline Usina 2 & 0 & 0 & 510,6 & 100 & 0 & $2.656,70$ & 0,00 \\
\hline Usina 3 & 8000 & 178 & 593,4 & 100 & 8000 & $2.851,67$ & $506.963,56$ \\
\hline Usina 4 & 23500 & 522 & 690,4 & 100 & 23500 & $3.313,73$ & $1.730 .503,44$ \\
\hline Usina 5 & 15000 & 333 & 629,7 & 100 & 15000 & $3.062,99$ & $1.020 .996,67$ \\
\hline Usina 6 & 8173 & 182 & 789,1 & 100 & 8173 & $3.846,51$ & $698.611,69$ \\
\hline Usina 7 & 12000 & 267 & 511,1 & 100 & 12000 & $2.645,08$ & $705.354,67$ \\
\hline Usina 8 & 9000 & 200 & 383,0 & 100 & 9000 & $1.839,73$ & $367.946,00$ \\
\hline TOTAL & 107173 & 2382 & - & 100 & 107173 & - & $7.039 .145,03$ \\
\hline
\end{tabular}

EXEMPLO CENÁRIO 2 - SAFRA 2004/2005

TRANSPORTE RODOVIÁRIO PORTA-A-PORTA

\begin{tabular}{|l|r|}
\hline Mês & Dezembro \\
\hline Composição & 353 \\
\hline Lotação rodo. (ton) & 30 \\
\hline Rota & usina-porto-usina \\
\hline Frota & Terceirizada \\
\hline
\end{tabular}

\begin{tabular}{|c|c|c|c|c|c|c|}
\hline Usina & $\begin{array}{l}\text { Produção } \\
\text { (ton) }\end{array}$ & $\begin{array}{l}\text { Comprimento } \\
\operatorname{Arco}(\mathrm{km})\end{array}$ & $\begin{array}{l}\text { Carregamento } \\
(\%)\end{array}$ & $\begin{array}{l}\text { Carregamento } \\
\text { (ton) }\end{array}$ & $\begin{array}{l}\text { Valor do frete } \\
\mathrm{R} \$ / \text { ton }\end{array}$ & $\begin{array}{c}\text { Custo Total } \\
\text { Rodoviário (R\$) }\end{array}$ \\
\hline Usina 1 & 31500 & 554,5 & 100 & 31500 & 56,00 & $1.764 .000,00$ \\
\hline Usina 2 & 0 & 510,6 & 100 & 0 & 53,00 & 0,00 \\
\hline Usina 3 & 8000 & 593,4 & 100 & 8000 & 57,00 & $456.000,00$ \\
\hline Usina 4 & 23500 & 690,4 & 100 & 23500 & 59,00 & $1.386 .500,00$ \\
\hline Usina 5 & 15000 & 629,7 & 100 & 15000 & 61,00 & $915.000,00$ \\
\hline Usina 6 & 8173 & 789,1 & 100 & 8173 & 71,00 & $580.283,00$ \\
\hline Usina 7 & 12000 & 511,1 & 100 & 12000 & 52,00 & $624.000,00$ \\
\hline Usina 8 & 9000 & 383,0 & 100 & 9000 & 51,00 & $459.000,00$ \\
\hline TOTAL & 107173 & - & 100 & 107173 & - & $6.184 .783,00$ \\
\hline
\end{tabular}


EXEMPLO CENÁRIO 3 - 3S3B3 - SAFRA 2004/2005

\section{TRANSPORTE RODO-FERROVIÁRIO}

\begin{tabular}{|l|r|}
\hline Terminal & S. J. da Barra \\
\hline Mês & Dezembro \\
\hline Composição rodoviária & $3 \mathrm{~S} 3 \mathrm{~B} 3$ \\
\hline Lotação rodo. (ton) & 45 \\
\hline Custo ferro. oper. $(\mathrm{R} \$ /$ ton) & 38,51 \\
\hline Custo de transb. (R\$/ton) & 4,50 \\
\hline
\end{tabular}

\begin{tabular}{|c|c|}
\hline Usina & $\begin{array}{l}\text { Produção } \\
\text { (ton) }\end{array}$ \\
\hline Usina 1 & 31500 \\
\hline Usina 2 & 0 \\
\hline Usina 3 & 8000 \\
\hline Usina 4 & 23500 \\
\hline Usina 5 & 15000 \\
\hline Usina 6 & 8173 \\
\hline Usina 7 & 12000 \\
\hline Usina 8 & 9000 \\
\hline TOTAL & 107173 \\
\hline Terminal & Ribeirão Preto \\
\hline Mês & Dezembro \\
\hline Composição rodoviária & 3S3B3 \\
\hline Lotação rodo. (ton) & 45 \\
\hline Custo ferro. oper. (R\$/ton) & 35,42 \\
\hline Custo de transb. (R\$/ton) & 3,80 \\
\hline
\end{tabular}

\begin{tabular}{|c|c|c|}
\hline & Usina & $\begin{array}{l}\text { Produção } \\
\text { (ton) }\end{array}$ \\
\hline & Usina 1 & 9000 \\
\hline & Usina 2 & 0 \\
\hline & Usina 3 & 8000 \\
\hline 点 & Usina 4 & 23500 \\
\hline & Usina 5 & 15000 \\
\hline & Usina 6 & 8173 \\
\hline & Usina 7 & 12000 \\
\hline & Usina 8 & 9000 \\
\hline
\end{tabular}

\begin{tabular}{|l|r|r|}
\hline \multicolumn{1}{|c|}{ Usina } & \multicolumn{1}{c|}{$\begin{array}{c}\text { Distância } \\
\text { usina-terminal }(\mathrm{km})\end{array}$} & $\begin{array}{c}\text { Distância } \\
\text { usina-porto }(\mathrm{km})\end{array}$ \\
\hline Usina 1 & 16,6 & 554,5 \\
\hline Usina 2 & 90,9 & 510,6 \\
\hline Usina 3 & 52,5 & 593,4 \\
\hline Usina 4 & 204,7 & 690,4 \\
\hline Usina 5 & 75,0 & 629,7 \\
\hline Usina 6 & 36,9 & 789,1 \\
\hline Usina 7 & 43,2 & 511,1 \\
\hline Usina 8 & 299,5 & 383,0 \\
\hline
\end{tabular}

Carregamento

Carregamento

$N^{\circ}$ viagens

usina-terminal-usina Rodo-ferro (ton)

(R\$) TransCAD

Custo rodo

ponta $(\mathrm{R} \$)$

Custo

erroviário $(\mathrm{R} \$)$

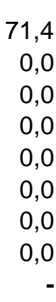

22500

507,45

293,17

1142,38

418,57

2047,45

241,26
1870,78

$46.355,93$

0,00

0,00

0,00

0,00

0,00

$46.355,93$

500

Distância

\begin{tabular}{|l|r|r|}
\hline \multicolumn{1}{|c|}{ Usina } & \multicolumn{1}{|c|}{$\begin{array}{c}\text { Distância } \\
\text { usina-terminal }(\mathrm{km})\end{array}$} & $\begin{array}{c}\text { Distância } \\
\text { usina-porto }(\mathrm{km})\end{array}$ \\
\hline Usina 1 & 74,1 & 554,5 \\
\hline Usina 2 & 51,6 & 510,6 \\
\hline Usina 3 & 94,1 & 593,4 \\
\hline Usina 4 & 229,6 & 690,4 \\
\hline Usina 5 & 146,1 & 629,7 \\
\hline Usina 6 & 391,8 & 789,1 \\
\hline Usina 7 & 30,8 & 511,1 \\
\hline Usina 8 & 176,8 & 383,0 \\
\hline
\end{tabular}

Carregamento

Rodo-ferro (\%)

Carregamento

$N^{\circ}$ viagens

usina-terminal-usina Rodo-ferro (ton)

Ponta rodo

(R\$) TransCAD

Custo ponta

413,32
287,63

413,32
287,63
524,92
1281,01

813,58

2185,98

171,57
146,03

$82.659,87$
0.00

0,00
0,00

0,00
0,00

0,00

0,00
0,00

0,00

967.744,35

Rodo-ferroviário $(\mathrm{R} \$)$ 1.014.100,28

1500

0

00,0

0,0
0,0
0,00
$17.497,33$
0,00
0,00
$45.752,00$

0,00
Custo

Ferroviário ( $R \$) \quad$ Custo

$\begin{array}{rr}0,00 & 0,00 \\ 58.830,00 & 76.327,33\end{array}$

$\begin{array}{ll}0,00 & 0,00 \\ 0,00 & 0,00\end{array}$

$0,00 \quad 0,00$

$470.640,00 \quad 516.392,00$
352.962,35 Rodo-ferroviário ( $R$ \$) 


TOTAL
\begin{tabular}{|l|r|}
\hline Terminal & $\mathbf{8 4 6 7 3}$ \\
\hline Mês & Eng. Schimitt \\
\hline Composição rodoviária & Dezembro \\
\hline Lotação rodo. (ton) & $3 \mathrm{S3B3}$ \\
\hline Custo ferro. oper. (R\$/ton) & 45 \\
\hline Custo de transb. (R\$/ton) & 40,70 \\
\hline
\end{tabular}

\begin{tabular}{|c|c|c|c|}
\hline \multirow{10}{*}{ 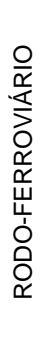 } & \multirow{10}{*}{$\begin{array}{l}\text { Usina } 1 \\
\text { Usina } 2 \\
\text { Usina } 3 \\
\text { Usina 4 } \\
\text { Usina } 5 \\
\text { Usina 6 } \\
\text { Usina } 7 \\
\text { Usina } 8 \\
\text { TOTAL }\end{array}$} & $\begin{array}{l}\text { Produção } \\
\text { (ton) }\end{array}$ & $\begin{array}{l}\text { Carregamento } \\
\text { Rodo-ferro (\%) }\end{array}$ \\
\hline & & 31500 & \\
\hline & & 0 & \\
\hline & & 8000 & \\
\hline & & 23500 & \\
\hline & & 15000 & \\
\hline & & 8173 & \\
\hline & & 12000 & \\
\hline & & 9000 & \\
\hline & & 107173 & \\
\hline
\end{tabular}

\begin{tabular}{|c|c|c|}
\hline \multicolumn{3}{|c|}{22500} \\
\hline Usina & $\begin{array}{c}\text { Distância } \\
\text { usina-terminal }(\mathrm{km})\end{array}$ & $\begin{array}{c}\text { Distância } \\
\text { usina-porto }(\mathrm{km})\end{array}$ \\
\hline Usina 1 & 189,4 & 554,5 \\
\hline Usina 2 & 175,0 & 510,6 \\
\hline Usina 3 & 161,9 & 593,4 \\
\hline Usina 4 & 98,9 & 690,4 \\
\hline Usina 5 & 129,5 & 629,7 \\
\hline Usina 6 & 194,9 & 789,1 \\
\hline Usina 7 & 214,9 & 511,1 \\
\hline Usina 8 & 250,8 & 383,0 \\
\hline
\end{tabular}

Carregamento
Rodo-ferro (ton)

$N^{\circ}$ viagens
ponta rodo

$\begin{array}{ll}0,0 & 0 \\ 0,0 & 0\end{array}$

$\begin{array}{lr}0,0 & 0 \\ 0,0 & 0\end{array}$

$\begin{array}{rr}0,6 & 10000 \\ 0,0 & 0\end{array}$

$\begin{array}{ll}0,0 & 0 \\ 0,0 & 0\end{array}$

$0,0 \quad 10000$
(RS) Trans-terminal-usina

Custo rodo

1056,97
976,53

$145.909,20$

$\begin{array}{rr}0 & 1056,97 \\ 0 & 976,53 \\ 0 & 903,50 \\ 222 & 552,01 \\ 0 & 722,54 \\ 0 & 1087,59 \\ 0 & 1199,37 \\ 0 & 1430,66 \\ \mathbf{2 2 2} & \text {. }\end{array}$

ponta $(\mathrm{R} \$)$
$882.432,35$

1.028.341,55

Custo Ferroviário $(\mathrm{R} \$) \quad$ Rodo-ferroviário $(\mathrm{R} \$)$ $\begin{array}{rrr}0,00 & 0,00 & 0,00 \\ 0,00 & 0,00 & 0,00\end{array}$ $\begin{array}{rrr}0,00 & 0,00 & 0,00 \\ 0,00 & 0,00 & 0,00\end{array}$ $\begin{array}{lll}122.665,45 & 450.787,38 & 573.452,83\end{array}$ $\begin{array}{lll}0,00 & 0,00 & 0,00 \\ 0,00 & 0,00 & 0,00\end{array}$ $0,00 \quad 0,00 \quad 0,00$

$\begin{array}{rrr}0,00 & 0,00 & 0,00 \\ \mathbf{2 2 . 6 6 5 , 4 5} & \mathbf{4 5 0 . 7 8 7 , 3 8} & \mathbf{5 7 3 . 4 5 2 , 8 3}\end{array}$

\section{TRANSPORTE RODOVIÁRIO PORTA-PORTA COMPLEMENTAR}

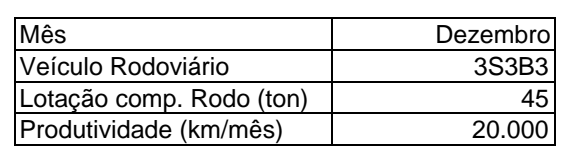

\begin{tabular}{|c|c|}
\hline Usina & $\begin{array}{l}\text { Produção } \\
\text { (ton) }\end{array}$ \\
\hline Usina 1 & 31500 \\
\hline Usina 2 & 0 \\
\hline Usina 3 & 8000 \\
\hline Usina 4 & 23500 \\
\hline Usina 5 & 15000 \\
\hline Usina 6 & 8173 \\
\hline Usina 7 & 12000 \\
\hline Usina 8 & 9000 \\
\hline TOTAL & 107173 \\
\hline
\end{tabular}

Carregamento
Rodo-ferro (\%)

$\begin{array}{rrrrrr} & \begin{array}{c}\text { Carregamento } \\ \text { porta-porta Rodo (\%) }\end{array} & \begin{array}{c}\text { Carregamento } \\ \text { porta-porta rodo (t) }\end{array} & \begin{array}{c}\text { No viagens } \\ \text { porta-porta rodo }\end{array} & \begin{array}{c}\text { usina-porto (R\$) } \\ \text { TransCAD }\end{array} & \begin{array}{c}\text { Custo Rodoviário } \\ \text { porta-porta (R\$) }\end{array} \\ 100,0 & 0,0 & 0 & 0 & 2.869,67 & 0,0 \\ 0,0 & 100,0 & 0 & 0 & 2.656,70 & 0,0 \\ 0,0 & 100,0 & 8000 & 178 & 2.851,67 & 506.963,6 \\ 42,6 & 57,4 & 13500 & 300 & 3.313,73 & 994.139,6 \\ 0,0 & 100,0 & 15000 & 333 & 3.062,99 & 1.020 .996,7 \\ 0,0 & 100,0 & 8173 & 182 & 3.846,51 & 698.611,7 \\ 100,0 & 0,0 & 0 & 0 & 2.645,08 & 0.0 \\ 0,0 & 100,0 & 9000 & 200 & 1.839,73 & 367.946,0 \\ 49,9 & 50,1 & 53673 & 1193- & & 3.588 .657,5\end{array}$


RESUMO MENSAL DE CUSTOS DE TRANSPORTE

$\begin{array}{lr}\text { Usina } & \begin{array}{r}\text { Custo Rodoviário } \\ \text { porta-porta (R\$) }\end{array} \\ \text { Usina 1 } & 0,0 \\ \text { Usina 2 } & 0,0 \\ \text { Usina 3 } & 506.963,6 \\ \text { Usina 4 } & 994.139,6 \\ \text { Usina 5 } & 1.020 .996,7 \\ \text { Usina 6 } & 698.611,7 \\ \text { Usina 7 } & 0,0 \\ \text { Usina 8 } & 367.946,0 \\ \text { TOTAL } & \mathbf{3 . 5 8 8 . 6 5 7 , 5}\end{array}$

Rodo - Ponta ( $R \$)$ Custo Rodo-ferroviário $R \$)$

$\begin{array}{rr}129.015,79 & \text { Ferroviário }(\mathrm{R} \$) \\ 0 & 1.320 .706,71\end{array}$

0,00
0,00

0,00
$22.665,45$

0,00

0,00

$45.752,00$

297.433,25

$450.787,38$

0,00

0,00

2.242.134,1 \begin{tabular}{cccc} 
& Custo Total & \multicolumn{2}{c}{ Custo Relativo (\%) } \\
Total $(\mathrm{R} \$)$ & $(\mathrm{R} \$)$ & Rodo porta-porta & Rodo-ferroviá
\end{tabular}

1.449.722,50

0,00

0,00
$0,452,83$

0,00
$470.640,00$ $\begin{array}{rrr}1.449 .722,50 & 0,0 \\ 0,00 & \text { \#DIV/O! } & \\ 506.95 / 0 !\end{array}$

$\begin{array}{rr}0,00 & \text { \#DIV/O! } \\ 506.963,56 & 100,0\end{array}$

$0,00,0$
0,0

$\begin{array}{rrr}1.567 .592,45 & 63,4 & 36,6\end{array}$

$1.020 .996,67 \quad 100,0 \quad 0,0$

$\begin{array}{rrr}698.611,69 & 100,0 & 0,0 \\ 516.392,00 & 0,0 & 100,0\end{array}$

$367.946,00 \quad 100,0 \quad 100,0$

6.128.224,87

41,4 
EXEMPLO CENÁRIO 4 - SAFRA 2004/2005

TRANSPORTE RODO-FERROVIÁRIO

\begin{tabular}{|l|r|}
\hline Terminal & S. J. da Barra \\
\hline Mês & Dezembro \\
\hline Composição rodoviária & $3 \mathrm{~S} 3$ \\
\hline Lotação rodo. (ton) & 30 \\
\hline Custo ferro. oper. $(\mathrm{R} \$ /$ ton $)$ & 38,51 \\
\hline Custo de transb. $(\mathrm{R} \$ /$ ton) & 4,50 \\
\hline
\end{tabular}

\begin{tabular}{|c|c|}
\hline Usina & $\begin{array}{l}\text { Produção } \\
\text { (ton) }\end{array}$ \\
\hline Usina 1 & 31500 \\
\hline Usina 2 & 0 \\
\hline Usina 3 & 8000 \\
\hline Usina 4 & 23500 \\
\hline Usina 5 & 15000 \\
\hline Usina 6 & 8173 \\
\hline Usina 7 & 12000 \\
\hline Usina 8 & 9000 \\
\hline TOTAL & 107173 \\
\hline Terminal & Ribeirão Preto \\
\hline Mês & Dezembro \\
\hline Composição rodoviária & $3 \mathrm{S3}$ \\
\hline Lotação rodo. (ton) & 30 \\
\hline Custo ferro. oper. (R\$/ton) & 35,42 \\
\hline Custo de transb. (R\$/ton) & 3,80 \\
\hline
\end{tabular}

\begin{tabular}{|c|c|c|}
\hline & Usina & $\begin{array}{l}\text { Produção } \\
\text { (ton) }\end{array}$ \\
\hline & Usina 1 & 9000 \\
\hline & Usina 2 & 0 \\
\hline & Usina 3 & 8000 \\
\hline 点 & Usina 4 & 23500 \\
\hline & Usina 5 & 15000 \\
\hline & Usina 6 & 8173 \\
\hline & Usina 7 & 12000 \\
\hline & Usina 8 & 9000 \\
\hline
\end{tabular}

\begin{tabular}{|l|r|r|}
\hline \multicolumn{1}{|c|}{ Usina } & \multicolumn{1}{c|}{$\begin{array}{c}\text { Distância } \\
\text { usina-terminal }(\mathrm{km})\end{array}$} & $\begin{array}{c}\text { Distância } \\
\text { usina-porto }(\mathrm{km})\end{array}$ \\
\hline Usina 1 & 16,6 & 554,5 \\
\hline Usina 2 & 90,9 & 510,6 \\
\hline Usina 3 & 52,5 & 593,4 \\
\hline Usina 4 & 204,7 & 690,4 \\
\hline Usina 5 & 75,0 & 629,7 \\
\hline Usina 6 & 366,9 & 789,1 \\
\hline Usina 7 & 43,2 & 511,1 \\
\hline Usina 8 & 299,5 & 383,0 \\
\hline
\end{tabular}

Carregamento Rodo-ferro (\%)

\begin{tabular}{|c|c|c|c|c|}
\hline $\begin{array}{c}\text { Carregamento } \\
\text { Rodo-ferro (ton) }\end{array}$ & $\begin{array}{l}\text { Frete ponta } \\
\mathrm{R} \$ \text { /ton }\end{array}$ & $\begin{array}{l}\text { Frete ponta } \\
(\mathrm{R} \$)\end{array}$ & $\begin{array}{c}\text { Frete } \\
\text { Ferroviário (R\$) }\end{array}$ & $\begin{array}{c}\text { Frete } \\
\text { Rodo-ferroviário }(\mathrm{R} \$\end{array}$ \\
\hline 22500 & 4,35 & $97.876,96$ & $967.744,35$ & $1.065 .621,31$ \\
\hline 0,0 & 0,00 & 0,00 & 0,00 & 0,00 \\
\hline 0,0 & 7,80 & 0,00 & 0,00 & 0,00 \\
\hline 0,0 & 0,00 & 0,00 & 0,00 & 0,00 \\
\hline 0,0 & 8,00 & 0,00 & 0,00 & 0,00 \\
\hline 0,0 & 0,00 & 0,00 & 0,00 & 0,00 \\
\hline 0,0 & 7,45 & 0,00 & 0,00 & 0,00 \\
\hline 0 & 0,00 & 0,00 & 0,00 & 0,00 \\
\hline 22500 & & $97.876,96$ & $967.744,35$ & $1.065 .621,31$ \\
\hline
\end{tabular}

\begin{tabular}{|l|r|r|}
\hline \multicolumn{1}{|c|}{ Usina } & \multicolumn{1}{|c|}{$\begin{array}{c}\text { Distância } \\
\text { usina-terminal }(\mathrm{km})\end{array}$} & $\begin{array}{c}\text { Distância } \\
\text { usina-porto }(\mathrm{km})\end{array}$ \\
\hline Usina 1 & 74,1 & 554,5 \\
\hline Usina 2 & 51,6 & 510,6 \\
\hline Usina 3 & 94,1 & 593,4 \\
\hline Usina 4 & 229,6 & 690,4 \\
\hline Usina 5 & 146,1 & 629,7 \\
\hline Usina 6 & 391,8 & 789,1 \\
\hline Usina 7 & 30,8 & 511,1 \\
\hline Usina 8 & 176,8 & 383,0 \\
\hline
\end{tabular}

Carregamento
Rodo-ferro (\%) Carregamento
Rodo-ferro (ton) Frete ponta Frete ponta Frete Frete

100,0
0,0
18,8
0,0
0,0
0,0
100,0
0,0

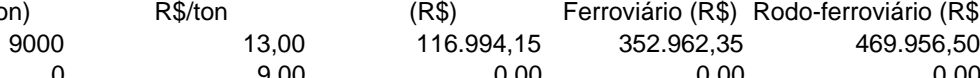

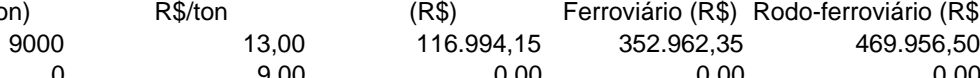
$\begin{array}{lrrrr} & & & & \\ 9000 & \mathrm{R} \$ / \text { ton } & (\mathrm{R} \$) & \text { Ferroviário }(\mathrm{R} \$) & \text { Rodo-ferroviário (R\$) } \\ & 13,00 & 116.994,15 & 352.962,35 & 469.956,50\end{array}$

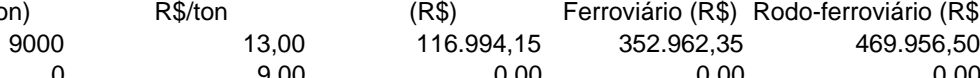

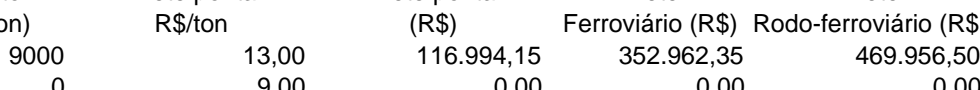
$\begin{array}{rrrrr}0 & 9,00 & 0,00 & 0,00 & 0,00 \\ 1500 & 14,00 & 21.000,00 & 58.830,00 & 79.830,00\end{array}$ $\begin{array}{rrrrr}0 & 0,00 & 0,00 & 0,00 & 0,00 \\ 0 & 0,00 & 0,00 & 0,00 & 0,00\end{array}$ $\begin{array}{rrrr}0 & 0,00 & 0,00 & 0,00\end{array}$

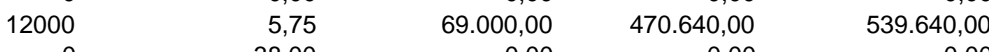




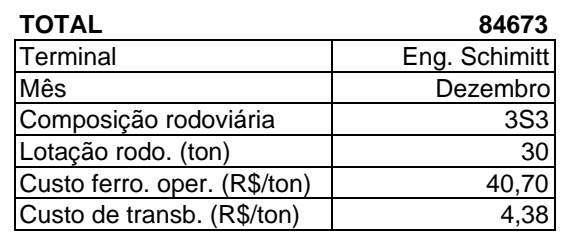

\begin{tabular}{|c|c|c|}
\hline Usina & $\begin{array}{l}\text { Produção } \\
\text { (ton) }\end{array}$ & $\begin{array}{l}\text { Carregamento } \\
\text { Rodo-ferro (\%) }\end{array}$ \\
\hline Usina 1 & 31500 & \\
\hline Usina 2 & 0 & \\
\hline Usina 3 & 8000 & \\
\hline Usina 4 & 23500 & \\
\hline Usina 5 & 15000 & \\
\hline Usina 6 & 8173 & \\
\hline Usina 7 & 12000 & \\
\hline Usina 8 & 9000 & \\
\hline TOTAL & 107173 & \\
\hline
\end{tabular}

\section{TRANSPORTE RODOVIARIO PORTA-PORTA COMPLEMENTAR}

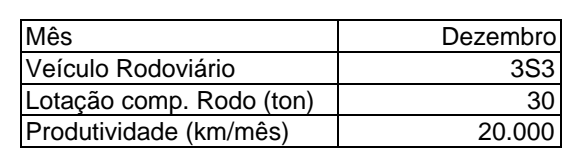

\begin{tabular}{|c|c|}
\hline Usina & $\begin{array}{l}\text { Produção } \\
\text { (ton) }\end{array}$ \\
\hline Usina 1 & 31500 \\
\hline Usina 2 & 0 \\
\hline Usina 3 & 8000 \\
\hline Usina 4 & 23500 \\
\hline Usina 5 & 15000 \\
\hline Usina 6 & 8173 \\
\hline Usina 7 & 12000 \\
\hline Usina 8 & 9000 \\
\hline TOTAL & 107173 \\
\hline
\end{tabular}

\begin{tabular}{|c|c|c|c|c|}
\hline $\begin{array}{l}\text { Carregamento } \\
\text { Rodo-ferro (\%) }\end{array}$ & $\begin{array}{c}\text { Carregamento } \\
\text { porta-porta Rodo (\%) }\end{array}$ & $\begin{array}{l}\text { Carregamento } \\
\text { porta-porta rodo (t) }\end{array}$ & $\begin{array}{l}\text { Frete porta-porta } \\
\mathrm{R} \$ / \text { ton }\end{array}$ & $\begin{array}{c}\text { Frete } \\
\text { porta-porta (R\$) }\end{array}$ \\
\hline 100,0 & 0,0 & 0 & 56,00 & 0,0 \\
\hline 0,0 & 100,0 & 0 & 53,00 & 0,0 \\
\hline 0,0 & 100,0 & 8000 & 57,00 & $456.000,0$ \\
\hline 42,6 & 57,4 & 13500 & 59,00 & $796.516,5$ \\
\hline 0,0 & 100,0 & 15000 & 61,00 & $915.000,0$ \\
\hline 0,0 & 100,0 & 8173 & 71,00 & $580.283,0$ \\
\hline 100,0 & 0,0 & 0 & 52,00 & 0,0 \\
\hline 0,0 & 100,0 & 9000 & 51,00 & $459.000,0$ \\
\hline 49,9 & 50,1 & $53673-$ & & 3.206.799,5 \\
\hline
\end{tabular}

\begin{tabular}{|c|c|c|c|c|}
\hline \multicolumn{2}{|l|}{22500} & $206.994,15$ & \multirow[t]{10}{*}{$882.432,35$} & \multirow[t]{10}{*}{$1.089 .426,50$} \\
\hline \begin{tabular}{|l|l} 
Usina & \\
\end{tabular} & \begin{tabular}{c|} 
Distância \\
usina-terminal $(\mathrm{km})$ \\
\end{tabular} & $\begin{array}{c}\text { Distância } \\
\text { usina-porto }(\mathrm{km}) \\
\end{array}$ & & \\
\hline Usina 1 & 189,4 & 554,5 & & \\
\hline Usina 2 & 175,0 & 510,6 & & \\
\hline Usina 3 & 161,9 & 593,4 & & \\
\hline Usina 4 & 98,9 & 690,4 & & \\
\hline Usina 5 & 129,5 & 629,7 & & \\
\hline Usina 6 & 194,9 & 789,1 & & \\
\hline Usina 7 & 214,9 & 511,1 & & \\
\hline Usina 8 & 250,8 & 383,0 & & \\
\hline $\begin{array}{l}\text { Carregamento } \\
\text { Rodo-ferro (ton) }\end{array}$ & $\begin{array}{l}\text { Frete ponta } \\
\mathrm{R} \$ / \text { ton }\end{array}$ & $\begin{array}{l}\text { Frete ponta } \\
\quad(\mathrm{R} \$)\end{array}$ & $\begin{array}{c}\text { Frete } \\
\text { Ferroviário (R\$) }\end{array}$ & $\begin{array}{c}\text { Frete } \\
\text { Rodo-ferroviário }(R \$)\end{array}$ \\
\hline 0 & 0,00 & 0,00 & 0,00 & $\quad 0,00$ \\
\hline 0 & 0,00 & 0,00 & 0,00 & 0,00 \\
\hline 0 & 0,00 & 0,00 & 0,00 & 0,00 \\
\hline 10000 & 12,00 & $119.996,64$ & $430.087,96$ & $550.084,60$ \\
\hline 0 & 0,00 & 0,00 & 0,00 & 0,00 \\
\hline 0 & 23,65 & 0,00 & 0,00 & 0,00 \\
\hline 0 & 0,00 & 0,00 & 0,00 & 0,00 \\
\hline 0 & 0,00 & 0,00 & 0,00 & 0,00 \\
\hline 10000 & & $119.996,64$ & $430.087,96$ & $550.084,60$ \\
\hline
\end{tabular}


RESUMO MENSAL DE CUSTOS DE TRANSPORTE

Usina 1
Usina 2
Usina 3
Usina 4
Usina 5
Usina 6
Usina 7
Usina 8

Custo Rodoviário Custo Rodo-ferroviário R\$) porta-porta ( $R \$) \quad$ Rodo - Ponta ( $R \$)$

$$
\begin{array}{r}
0,0 \\
456.000,0
\end{array}
$$

$796.516,5$

$915.000,0$
$580.283,0$

0,00

$19.996,64$
0,00

Ferroviário $(\mathrm{R} \$)$

$1.320 .706,71$
0,00

Total (R\$)

\begin{tabular}{cc}
$\begin{array}{cc}\text { Custo Total } & \text { Custo Relativo (\%) } \\
(\mathrm{R} \$) & \text { Rodo porta-porta }\end{array}$ \\
\hline
\end{tabular}

1.535.577,81 $0,00 \quad$ \#DIV/O!

0,00
0,00

0,00
$430.087,96$

0,00
0,00

0,00

$550.084,60$

$1.346 .601,12$

DIV/O!

100,0
59,2

$\begin{array}{lr}950.283,00 & 100,0 \\ 539.640,00 & 100,0\end{array}$

$459.000,0$

$3.206 .799,5$

$69.000,00$

$0,00 \quad 580.283,00$

$470.640,00$
0,00

403.867,75

2.221.434,7

0,00

$539.640,00$

0,0

2.625.302,41

$\mathbf{5 . 8 3 2 . 1 0 1 , 9 3}$

$\mathbf{5 5 , 0}$

Rodo-ferroviário

\#DIV/O! 100,

0,0
40,8

0,0

0,0
100,0
0,0
TOTAL 
EXEMPLO CENÁRIO 5 - 3S3B3 - SAFRA 2004/2005

\section{TRANSPORTE RODO-FERROVIÁRIO}

\begin{tabular}{|l|r|}
\hline Terminal & S. J. da Barra \\
\hline Mês & Dezembro \\
\hline Composição rodoviária & $3 \mathrm{~S} 3 \mathrm{~B} 3$ \\
\hline Lotação rodo. (ton) & 45 \\
\hline Custo ferro. oper. $(\mathrm{R} \$ /$ ton) & 38,51 \\
\hline Custo de transb. (R\$/ton) & 4,50 \\
\hline
\end{tabular}

\begin{tabular}{|c|c|}
\hline Usina & $\begin{array}{l}\text { Produção } \\
\text { (ton) }\end{array}$ \\
\hline Usina 1 & 31500 \\
\hline Usina 2 & 0 \\
\hline Usina 3 & 8000 \\
\hline Usina 4 & 23500 \\
\hline Usina 5 & 15000 \\
\hline Usina 6 & 8173 \\
\hline Usina 7 & 12000 \\
\hline Usina 8 & 9000 \\
\hline TOTAL & 107173 \\
\hline Terminal & Ribeirão Preto \\
\hline Mês & Dezembro \\
\hline Composição rodoviária & 3S3B3 \\
\hline Lotação rodo. (ton) & 45 \\
\hline Custo ferro. oper. (R\$/ton) & 35,42 \\
\hline Custo de transb. (R\$/ton) & 3,80 \\
\hline
\end{tabular}

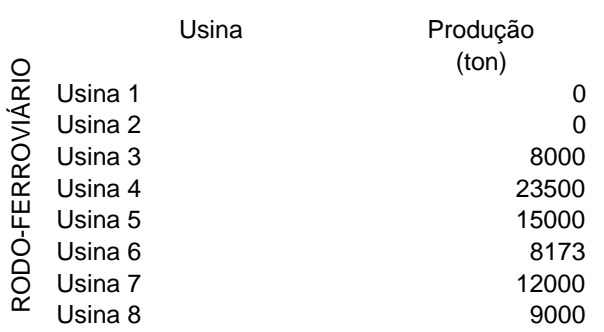

\begin{tabular}{|l|r|r|}
\hline \multicolumn{1}{|c|}{ Usina } & \multicolumn{1}{|c|}{$\begin{array}{c}\text { Distância } \\
\text { usina-terminal }(\mathrm{km})\end{array}$} & $\begin{array}{c}\text { Distância } \\
\text { usina-porto }(\mathrm{km})\end{array}$ \\
\hline Usina 1 & 16,6 & 554,5 \\
\hline Usina 2 & 90,9 & 510,6 \\
\hline Usina 3 & 52,5 & 593,4 \\
\hline Usina 4 & 204,7 & 690,4 \\
\hline Usina 5 & 75,0 & 629,7 \\
\hline Usina 6 & 36,9 & 789,1 \\
\hline Usina 7 & 43,2 & 511,1 \\
\hline Usina 8 & 299,5 & 383,0 \\
\hline
\end{tabular}

Carregamento

Carregamento

$\mathrm{N}^{\circ}$ viagens

usina-terminal-usina Custo ponta

Rodoviária ( $R \$$ )

Custo

Custo

Rodo-ferro (ton)

(R\$) TransCAD

$92,71 \quad 64.897,00$

Rodo-ferroviário $(\mathrm{R} \$)$

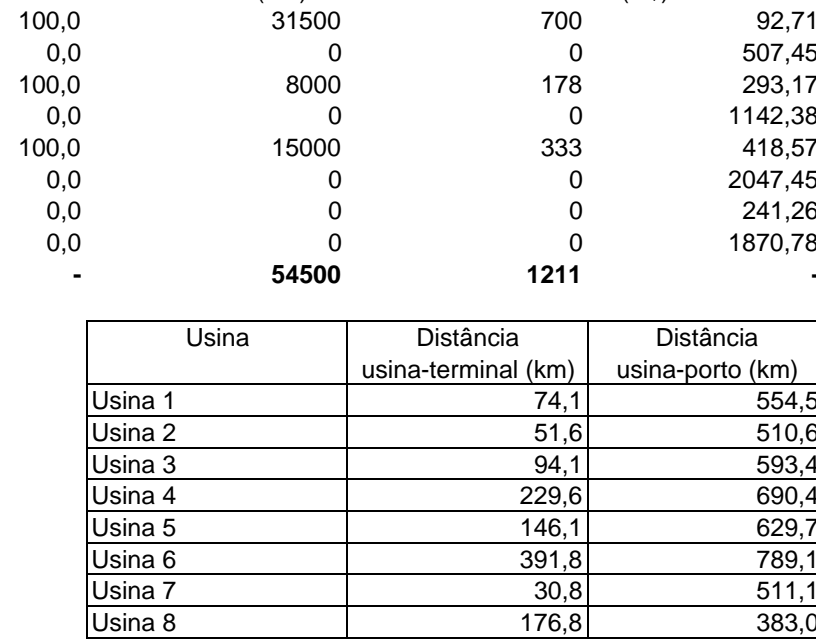

Carregamento

Rodo-ferro (\%)

0,0
100,0
0,0
0,0
0,0
0,0
100,0
100,0

Carregamento

No viagens

usina-terminal-usina Rodo-ferro (ton)

ponta rodo

(R\$) TransCAD

Custo rodo

ponta ( $R \$)$

Custo

Cirio $(R \$)$

1.354.815,00

$344.080,00$

0,00
$645.150,00$

$5.150,00$
0,00

0,00
0,00
0,00

0,00

$\mathbf{2 . 3 4 4 . 0 4 5 , 0 0}$

$1.419 .712,00$

0,00

$139.523,33$

0,00

$256.539,44$

413,32
287,63
524,92
1281,01
813,58
2185,98
171,57
1464,03

$\begin{array}{ll}413,32 & 0,00 \\ 87,63 & 0,00\end{array}$

$\begin{array}{ll}28,63 & 0,00 \\ 524,92 & 0,00\end{array}$

2185,98

171,5
1464,03

12000
9000

200
Ferroviário ( $R \$)$ Rodo-ferroviário $(R \$)$ $\begin{array}{rr}0,00 & \text { Rodo-ferroviário }(\mathrm{R} \$) \\ 0,00 & 0,00\end{array}$ $\begin{array}{ll}0,00 & 0,00 \\ 0,00 & 0,00\end{array}$ $0,00 \quad 0,00$

$\begin{array}{ll}0,00 & 0,00 \\ 0,00 & 0,00\end{array}$

$\begin{array}{rr}0,00 & 0,00 \\ 0 & 516392,00\end{array}$

$\begin{array}{rrr}45.752,00 & 470.640,00 & 516.392,00 \\ 292.806,00 & 352.980,00 & 645.786,00\end{array}$ 


TOTAL
\begin{tabular}{|l|r|}
\hline Terminal & 75673 \\
\hline Mês & Eng. Schimitt \\
\hline Composição rodoviária & Dezembro \\
\hline Lotação rodo. (ton) & $3 \mathrm{S3B3}$ \\
\hline Custo ferro. oper. (R\$/ton) & 45 \\
\hline Custo de transb. (R\$/ton) & 40,70 \\
\hline
\end{tabular}

\begin{tabular}{|c|c|c|}
\hline Usina & $\begin{array}{l}\text { Produção } \\
\text { (ton) }\end{array}$ & $\begin{array}{l}\text { Carregamento } \\
\text { Rodo-ferro (\%) }\end{array}$ \\
\hline Usina 1 & 31500 & \\
\hline Usina 2 & 0 & \\
\hline , Usina 3 & 8000 & \\
\hline$\frac{r}{\mathbb{r}}$ Usina 4 & 23500 & \\
\hline 荘 Usina 5 & 15000 & \\
\hline ○́ Usina 6 & 8173 & \\
\hline O Usina 7 & 12000 & \\
\hline 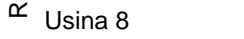 & 9000 & \\
\hline TOTAL & 107173 & \\
\hline
\end{tabular}

\begin{tabular}{|c|c|c|}
\hline \multicolumn{3}{|c|}{21000} \\
\hline Usina & $\begin{array}{c}\text { Distância } \\
\text { usina-terminal }(\mathrm{km})\end{array}$ & $\begin{array}{c}\text { Distância } \\
\text { usina-porto }(\mathrm{km})\end{array}$ \\
\hline Usina 1 & 189,4 & 554,5 \\
\hline Usina 2 & 175,0 & 510,6 \\
\hline Usina 3 & 161,9 & 593,4 \\
\hline Usina 4 & 98,9 & 690,4 \\
\hline Usina 5 & 129,5 & 629,7 \\
\hline Usina 6 & 194,9 & 789,1 \\
\hline Usina 7 & 214,9 & 511,1 \\
\hline Usina 8 & 250,8 & 383,0 \\
\hline
\end{tabular}

Carregamento
Rodo-ferro (to $)$

$\mathrm{N}^{\circ}$ viagens
Ponta rodo

usi

$\begin{array}{rrr} & \text { Rodo-ferro (ton) } & \text { Ponta rodo } \\ 0,0 & 0 & 0 \\ 0,0 & 0 & 0 \\ 0,0 & 0 & 0 \\ 00,0 & 23500 & 522 \\ 0,0 & 0 & 0 \\ 00,0 & 8173 & 182 \\ 0,0 & 0 & 0 \\ 0,0 & 0 & 0 \\ - & 31673 & 704\end{array}$

sina-terminal-usina

722,54

1087,59
1199,37

1430,66
$338.558,00$

$823.620,00$

$1.162 .178,00$

Rodoviária $(\mathrm{R} \$)$

Custo

$\begin{array}{rr}1056,97 & 0,00 \\ 976,53 & 0,00 \\ 903,50 & 0,00 \\ 552,01 & 288.271,89\end{array}$

$288.271,89$

197.530,51

0,00

0,00
$\mathbf{4 8 5 . 8 0 2 , 4 0}$

$\begin{array}{rr}0,00 & 0,00 \\ 0,00 & 0,00 \\ 0,00 & 0,00\end{array}$

$\begin{array}{rr}0,00 \\ 1.059 .380,00 & 0,00\end{array}$

$\begin{array}{rr}0,00 & 0,00 \\ 268.438 & 0.347 .651,89\end{array}$

$368.438,84$

0,00

0,00
$1.427 .818,84$

\section{TRANSPORTE RODOVIARIO PORTA-PORTA COMPLEMENTAR}

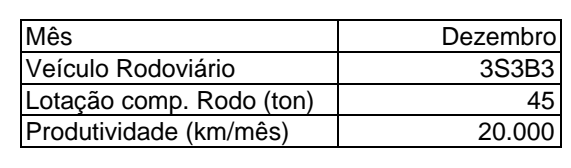

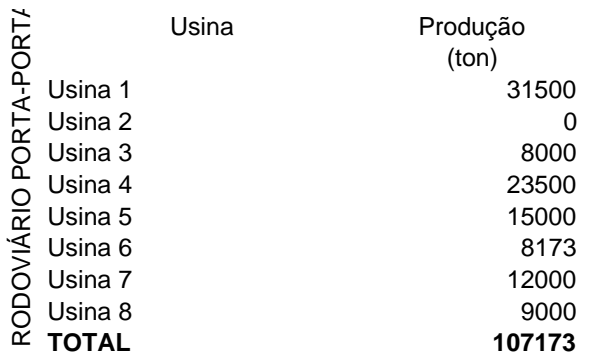

Carregamento
Rodo-ferro (\%)

$\begin{array}{lr} & \begin{array}{r}\text { Carregamento } \\ \text { porta-porta Rodo }\end{array} \\ 100,0 & \\ 100,0 & \\ 100,0 & \\ 100,0 & \\ 100,0 & \\ 100,0 & \\ 100,0 & \\ 100,0 & \\ 100,0 & \end{array}$

$\begin{array}{lr} & \text { Carregamento } \\ 0,0 & \text { porta-porta rodo } \\ 0,0 & \\ 0,0 & \\ 0 & \\ 0 & \\ 0 & \\ , 0 & \\ , 0 & \\ , 0 & \\ 0,0 & \end{array}$

usina-porto ( $\mathrm{R} \$$ ) Custo Rodoviário TransCAD porta-porta (R\$) $2.869,67$

$2.851,67$

$3.313,73$

$3.062,99$

$3.846,51$

$2.645,08$

$1.839,73$

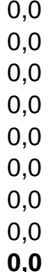


RESUMO MENSAL DE CUSTOS DE TRANSPORTE

Usina 1
Usina 2
Usina 3
Usina 4
Usina 5
Usina 6
Usina 7
Usina 8

Custo Rodoviário Custo Rodo-ferroviário R\$) porta-porta ( $R \$) \quad$ Rodo - Ponta ( $R \$)$

$$
\begin{array}{r}
0,00 \\
52.119,11
\end{array}
$$

$52.119,11$
$288.271,89$

$139.523,33$

$197.530,51$

$45.752,00$

$292.806,00$

Ferroviário ( $R \$)$ $1.354 .815,00$

otal $(\mathrm{R} \$)$

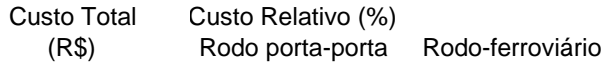

0,00
$396.199,11$

$396.199,11$
$347.651,89$

$784.673,33$

$565.969,35$

$470.640,00$

$516.392,00$

$645.786,00$

$5.676 .383,69$

$4.595 .483,8$
1.419.712,00
$0,00 \quad$ \#DIV/O!

$396.199,11$

$1.347 .651,89$

$784.673,33$

$565.969,35$

$516.392,00$

$645.786,00$

$5.676 .383,69$
\#DIV/O!

100,0

100,0

100,0

100,0

100,0

100,0

100,0
$0,0 \quad 1.080 .899,85$ 
EXEMPLO CENÁRIO 6 - SAFRA 2004/2005

TRANSPORTE RODO-FERROVIÁRIO

\begin{tabular}{|l|r|}
\hline Terminal & S. J. da Barra \\
\hline Mês & Dezembro \\
\hline Composição rodoviária & $3 \mathrm{~S} 3$ \\
\hline Lotação rodo. (ton) & 30 \\
\hline Custo ferro. oper. $(\mathrm{R} \$ /$ ton $)$ & 38,51 \\
\hline Custo de transb. $(\mathrm{R} \$ /$ ton) & 4,50 \\
\hline
\end{tabular}

\begin{tabular}{|c|c|}
\hline Usina & $\begin{array}{l}\text { Produção } \\
\text { (ton) }\end{array}$ \\
\hline Usina 1 & 31500 \\
\hline Usina 2 & 0 \\
\hline Usina 3 & 8000 \\
\hline Usina 4 & 23500 \\
\hline Usina 5 & 15000 \\
\hline Usina 6 & 8173 \\
\hline Usina 7 & 12000 \\
\hline Usina 8 & 9000 \\
\hline TOTAL & 107173 \\
\hline Terminal & Ribeirão Preto \\
\hline Mês & Dezembro \\
\hline Composição rodoviária & $3 \mathrm{S3}$ \\
\hline Lotação rodo. (ton) & 30 \\
\hline Custo ferro. oper. (R\$/ton) & 35,42 \\
\hline Custo de transb. (R\$/ton) & 3,80 \\
\hline
\end{tabular}

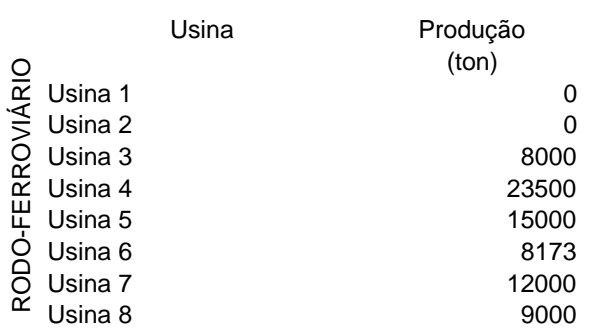

\begin{tabular}{|l|r|r|}
\hline \multicolumn{1}{|c|}{ Usina } & \multicolumn{1}{c|}{$\begin{array}{c}\text { Distância } \\
\text { usina-terminal }(\mathrm{km})\end{array}$} & $\begin{array}{c}\text { Distância } \\
\text { usina-porto }(\mathrm{km})\end{array}$ \\
\hline Usina 1 & 16,6 & 554,5 \\
\hline Usina 2 & 90,9 & 510,6 \\
\hline Usina 3 & 52,5 & 593,4 \\
\hline Usina 4 & 204,7 & 690,4 \\
\hline Usina 5 & 75,0 & 629,7 \\
\hline Usina 6 & 36,9 & 789,1 \\
\hline Usina 7 & 43,2 & 511,1 \\
\hline Usina 8 & 299,5 & 383,0 \\
\hline
\end{tabular}

Carregamento

Carregamento

Frete ponta

Frete ponta

(R\$)

Frete Frete

Rodo-ferro (ton)

$\mathrm{R} \$ /$ ton

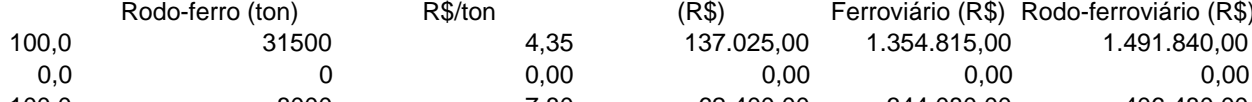

Ferroviário ( $R$ \$) Rodo-ferroviário ( $R \$)$ $1.354 .815,00 \quad 1.491 .840,00$

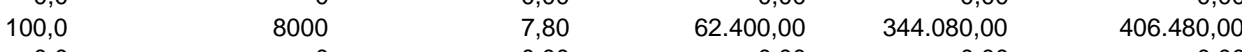
$\begin{array}{rrrr}0 & 0,00 & 0,00 & 0,00\end{array}$ $\begin{array}{rrrrr}15000 & 8,00 & 120.000,00 & 645.150,00 & 765.150,00\end{array}$

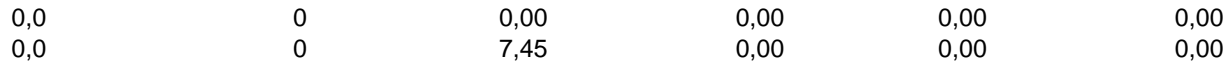

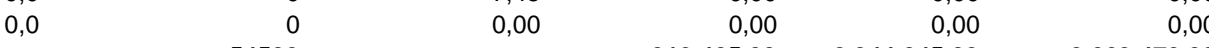

$\begin{array}{llll}54500 & 319.425,00 & 2.344 .045,00\end{array}$

\begin{tabular}{|c|c|c|}
\hline Usina & $\begin{array}{c}\text { Distância } \\
\text { usina-terminal }(\mathrm{km})\end{array}$ & $\begin{array}{c}\text { Distância } \\
\text { usina-porto }(\mathrm{km})\end{array}$ \\
\hline Usina 1 & 74,1 & 554,5 \\
\hline Usina 2 & 51,6 & 510,6 \\
\hline Usina 3 & 94,1 & 593,4 \\
\hline Usina 4 & 229,6 & 690,4 \\
\hline Usina 5 & 146,1 & 629,7 \\
\hline Usina 6 & 391,8 & 789,1 \\
\hline Usina 7 & 30,8 & 511,1 \\
\hline Usina 8 & 176,8 & 383,0 \\
\hline
\end{tabular}

Carregamento Rodo-ferro (\%)

Carregamento
Rodo-ferro (ton)
0
0
0
0
0
0
12000
9000

Frete ponta

Frete ponta

Frete

Frete

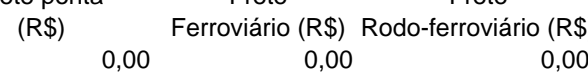

13,00

9,00
14,00

14,00
0,00

0,00

0,00

5,75

38,00

$\begin{array}{lll}0,00 & 0,00 & 0,00 \\ 0,00 & 0,00 & 0,00\end{array}$

$\begin{array}{lll}0,00 & 0,00 & 0,00\end{array}$

$\begin{array}{lll}0,00 & 0,00 & 0,00\end{array}$

$\begin{array}{lll}0,00 & 0,00 & 0,00 \\ 0,00 & 0,00 & 0,00\end{array}$

$69.000,00 \quad 470.640,00 \quad 539.640,00$

$342.000,00 \quad 352.980,00 \quad 694.980,00$ 


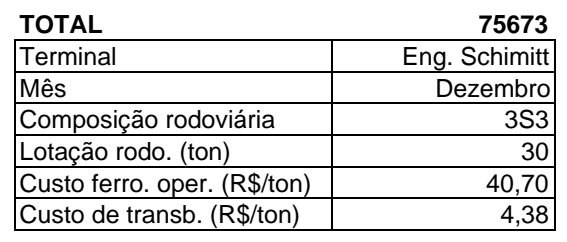

\begin{tabular}{|c|c|}
\hline Usina & $\begin{array}{l}\text { Produção } \\
\text { (ton) }\end{array}$ \\
\hline Usina 1 & 31500 \\
\hline Usina 2 & 0 \\
\hline Usina 3 & 8000 \\
\hline Usina 4 & 23500 \\
\hline Usina 5 & 15000 \\
\hline Usina 6 & 8173 \\
\hline Usina 7 & 12000 \\
\hline Usina 8 & 9000 \\
\hline TOTAL & 107173 \\
\hline \multicolumn{2}{|c|}{ TRANSPORTE RODOVIÁRIO PORTA-PORTA } \\
\hline Mês & Dezembro \\
\hline Veículo Rodoviário & $3 \mathrm{~S} 3$ \\
\hline Lotação comp. Rodo (ton) & 30 \\
\hline Produtividade (km/mês) & 20.000 \\
\hline
\end{tabular}

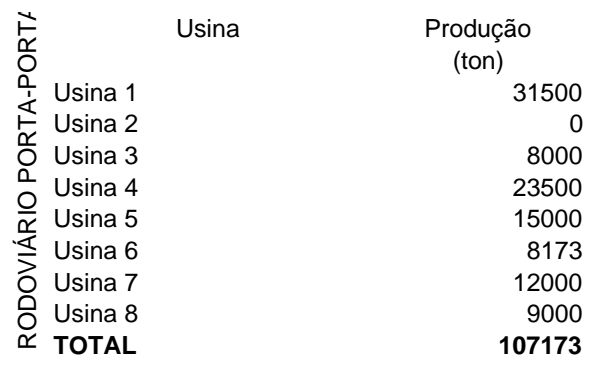

\begin{tabular}{|l|r|r|}
\hline \multicolumn{1}{|c|}{$\mathbf{2 1 0 0 0}$} & \multicolumn{1}{c|}{$\mathbf{4 1 1 . 0 0 0 , 0 0}$} \\
\hline & $\begin{array}{c}\text { Distância } \\
\text { usina-terminal (km) }\end{array}$ & $\begin{array}{c}\text { Distância } \\
\text { usina-porto }(\mathrm{km})\end{array}$ \\
\hline Usina 1 & 189,4 & 554,5 \\
\hline Usina 2 & 175,0 & 510,6 \\
\hline Usina 3 & 161,9 & 593,4 \\
\hline Usina 4 & 98,9 & 690,4 \\
\hline Usina 5 & 129,5 & 629,7 \\
\hline Usina 6 & 194,9 & 789,1 \\
\hline Usina 7 & 214,9 & 511,1 \\
\hline Usina 8 & 250,8 & 383,0 \\
\hline
\end{tabular}

Carregamento

Rodo-ferro (\%)

0,0
0,0
0,0
100,0
0,0
100,0
0,0
0,0
-

Carregamento

Frete ponta

Frete ponta

Frete

$823.620,00$

$1.234 .620,00$

Rodo-ferro (ton)

$\mathrm{R} \$$ ton

( $R \$)$

oviário $(\mathrm{R})$

Frete

$\begin{array}{rrrrr}0 & 0,00 & 0,00 & 0,00 & 0,00 \\ 0 & 0,00 & 0,00 & 0,00 & 0,00 \\ 0 & 0,00 & 0,00 & 0,00 & 0,00 \\ 23500 & 12,00 & 282.000,00 & 1.059 .380,00 & 1.341 .380,00 \\ 0 & 0,00 & 0,00 & 0,00 & 0,00 \\ 8173 & 23,65 & 193.291,45 & 368.438,84 & 561.730,29 \\ 0 & 0,00 & 0,00 & 0,00 & 0,00 \\ 0 & 0,00 & 0,00 & 0,00 & 0,00 \\ \mathbf{3 1 6 7 3} & - & \mathbf{4 7 5 . 2 9 1 , 4 5} & \mathbf{1 . 4 2 7 . 8 1 8 , 8 4} & \mathbf{1 . 9 0 3 . 1 1 0 , 2 9}\end{array}$

Carregamento

Rodo-ferro (\%)

$\begin{array}{lrr} & \text { Carregamento } & \text { Carregamento } \\ \text { porta-porta Rodo (\%) } & \text { porta-porta rodo (t) } \\ 100,0 & 0,0 & 0 \\ 100,0 & 0,0 & 0 \\ 100,0 & 0,0 & 0 \\ 100,0 & 0,0 & 0 \\ 100,0 & 0,0 & 0 \\ 100,0 & 0,0 & 0 \\ 100,0 & 0,0 & 0 \\ 100,0 & 0,0 & 0 \\ 100,0 & 0,0 & \end{array}$

Frete porta-porta $\mathrm{R} \$ /$ ton

Frete

porta-porta ( $\mathrm{R} \$$ )

$53,00 \quad 0,0$

$57,00 \quad 0,0$

$\begin{array}{ll}59,00 & 0,0 \\ 61,00 & 0,0\end{array}$

$71,00 \quad 0,0$

$\begin{array}{ll}52,00 & 0,0 \\ 51,00 & 0,0\end{array}$ 
RESUMO MENSAL DE CUSTOS DE TRANSPORTE

Usina 1
Usina 2
Usina 3
Usina 4
Usina 5
Usina 6
Usina 7
Usina 8

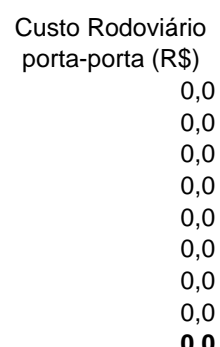

usto Rodo-ferroviário R\$) Rodo - Ponta ( $R \$)$

0,00
$62.400,00$
$282.000,00$
$120.000,00$
$193.291,45$
$69.000,00$
$342.000,00$
$1.205 .716,45$

Ferroviário $(\mathrm{R} \$)$ $1.354 .815,00$

Total $(\mathrm{R} \$)$

Custo Total Custo Relativo (\%)
(R\$)

( $R \$) \quad$ Rodo porta-porta Rodo-ferroviário

$\begin{array}{rr}0,0 & 0,00 \\ 0,0 & 62.400,00\end{array}$

$1.354 .815,00$
0,00

$344.080,00$

$1.059 .380,00$

$645.150,00$

$368.438,84$

1.00
0,00

$406.480,00$

$1.341 .380,00$

$765.150,00$

$561.730,29$

$539.640,00$

$352.980,00$

$694.980,00$

$\mathbf{4 . 5 9 5 . 4 8 3 , 8}$

$5.801 .200,29$
1.491.840,00
$0,00 \quad$ \#DIV/O!

$406.480,00$

1.341.380,00

$765.150,00$

$561.730,29$

$539.640,00$

$694.980,00$

$5.801 .200,29$
\#DIV/O!

100,0

100,0

100,0

100,0

100,0

100,0

100,0 
APÊNDICE K

RESUMO DOS CUSTOS ABSOLUTOS DE TRANSPORTE 


\section{RESUMO DOS CUSTOS ABSOLUTOS DE TRANSPORTE}

\begin{tabular}{|c|c|c|c|c|c|c|c|c|c|}
\hline \multicolumn{10}{|c|}{ CUSTO ABSOLUTO (R\$) } \\
\hline Mês & Usina 1 & Usina 2 & Usina 3 & Usina 4 & Usina 5 & Usina 6 & Usina 7 & Usina 8 & TOTAL \\
\hline Abril & $3.237 .247,04$ & $680.837,04$ & $1.198 .259,07$ & $3.470 .461,30$ & $1.106 .078,52$ & 0,00 & $679.122,22$ & $229.791,67$ & $10.601 .796,85$ \\
\hline Maio & $2.145 .617,22$ & $1.361 .674,07$ & $1.004 .991,48$ & $2.388 .759,07$ & $1.063 .537,04$ & $15.279,18$ & $916.815,00$ & $331.921,30$ & $9.228 .594,36$ \\
\hline Junho & $2.409 .114,07$ & $2.042 .511,11$ & $695.763,33$ & $2.569 .042,78$ & $1.488 .951,85$ & $979.149,64$ & $916.815,00$ & $306.388,89$ & $11.407 .736,68$ \\
\hline Julho & $1.505 .696,30$ & $1.361 .674,07$ & $309.228,15$ & $2.794 .397,41$ & $765.746,67$ & $424.184,21$ & $407.473,33$ & $459.583,33$ & $8.027 .983,47$ \\
\hline Agosto & $752.848,15$ & $2.042 .511,11$ & $231.921,11$ & $1.532 .411,48$ & $510.497,78$ & $322.358,63$ & $305.605,00$ & $408.518,52$ & $6.106 .671,78$ \\
\hline Setembro & $1.129 .272,22$ & $1.361 .674,07$ & $347.881,67$ & $991.560,37$ & $850.829,63$ & $178.328,32$ & $339.561,11$ & $434.050,93$ & $5.633 .158,32$ \\
\hline Outubro & $1.355 .126,67$ & $2.042 .511,11$ & $347.881,67$ & $1.487 .340,56$ & $1.233 .702,96$ & $163.155,99$ & $509.341,67$ & $280.856,48$ & $7.419 .917,10$ \\
\hline Novembro & $1.129 .272,22$ & $1.361 .674,07$ & $231.921,11$ & $991.560,37$ & $978.454,07$ & $264.661,03$ & $441.429,44$ & $255.324,07$ & $5.654 .296,40$ \\
\hline Dezembro & $2.371 .471,67$ & 0,00 & $618.456,30$ & $2.118 .333,52$ & $1.276 .244,44$ & $873.263,86$ & $814.946,67$ & $459.583,33$ & $8.532 .299,79$ \\
\hline Janeiro & $150.569,63$ & 0,00 & $154.614,07$ & $180.283,70$ & $85.082,96$ & $121.058,11$ & $67.912,22$ & $51.064,81$ & $810.585,52$ \\
\hline TOTAL & $16.186 .235,19$ & $12.255 .066,67$ & $5.140 .917,96$ & $18.524 .150,56$ & $9.359 .125,93$ & $3.341 .438,97$ & $5.399 .021,67$ & $3.217 .083,33$ & $73.423 .040,27$ \\
\hline
\end{tabular}

\begin{tabular}{|c|c|c|c|c|c|c|c|c|c|}
\hline \multicolumn{10}{|c|}{ CUSTO ABSOLUTO (R\$) } \\
\hline Mês & Usina 1 & Usina 2 & Usina 3 & Usina 4 & Usina 5 & Usina 6 & Usina 7 & Usina 8 & TOTAL \\
\hline Abril & $2.965 .753,00$ & $678.936,67$ & $1.129 .578,00$ & $3.260 .334,00$ & $1.017 .592,33$ & 0,00 & $642.330,00$ & $211.569,00$ & $9.906 .093,00$ \\
\hline Maio & $1.965 .673,50$ & $1.357 .873,33$ & $947.388,00$ & $2.244 .126,00$ & $978.454,17$ & $14.056,85$ & $867.145,50$ & $305.599,67$ & $8.680 .317,02$ \\
\hline Junho & $2.207 .072,00$ & $2.036 .810,00$ & $655.884,00$ & $2.413 .494,00$ & $1.369 .835,83$ & $900.818,15$ & $867.145,50$ & $282.092,00$ & $10.733 .151,48$ \\
\hline Julho & $1.379 .420,00$ & $.357 .873,33$ & $291.504,00$ & $2.625 .204,00$ & $704.487,00$ & $390.249,68$ & $385.398,00$ & $423.138,00$ & $7.557 .274,01$ \\
\hline Agosto & $689.710,00$ & $2.036 .810,00$ & $218.628,00$ & $1.439 .628,00$ & $469.658,00$ & $296.570,09$ & $289.048,50$ & $376.122,67$ & $5.816 .175,26$ \\
\hline Setembro & $1.034 .565,00$ & $1.357 .873,33$ & $327.942,00$ & $931.524,00$ & $782.763,33$ & $164.062,14$ & $321.165,00$ & $399.630,33$ & $5.319 .525,14$ \\
\hline Outubro & $1.241 .478,00$ & $2.036 .810,00$ & $327.942,00$ & $1.397 .286,00$ & $1.135 .006,83$ & $150.103,59$ & $481.747,50$ & $258.584,33$ & 7.028.958,26 \\
\hline Novembro & $1.034 .565,00$ & $1.357 .873,33$ & $218.628,00$ & $931.524,00$ & $900.177,83$ & $243.488,27$ & $417.514,50$ & $235.076,67$ & $5.338 .847,61$ \\
\hline Dezembro & $2.172 .586,50$ & 0,00 & $583.008,00$ & $1.990 .074,00$ & $1.174 .145,00$ & $803.403,18$ & $770.796,00$ & $423.138,00$ & 7.917.150,68 \\
\hline Janeiro & $137.942,00$ & 0,00 & $145.752,00$ & $169.368,00$ & $78.276,33$ & $111.373,52$ & $64.233,00$ & $47.015,33$ & $753.960,19$ \\
\hline$\overline{\text { TOTAL }}$ & $4.828 .765,00$ & $12.220 .860,00$ & $4.846 .254,00$ & $17.402 .562,00$ & $8.610 .396,67$ & $3.074 .125,48$ & $5.106 .523,50$ & $2.961 .966,00$ & $69.051 .452,64$ \\
\hline
\end{tabular}




\section{RESUMO DOS CUSTOS ABSOLUTOS DE TRANSPORTE}

\begin{tabular}{|c|c|c|c|c|c|c|c|c|c|}
\hline \multicolumn{10}{|c|}{ CUSTO ABSOLUTO (R\$) } \\
\hline Mês & Usina 1 & Usina 2 & Usina 3 & Usina 4 & Usina 5 & Usina 6 & Usina 7 & Usina 8 & TOTAL \\
\hline Abril & $3.001 .527,84$ & $646.224,32$ & $1.075 .155,41$ & $3.103 .256,08$ & $968.566,76$ & 0,00 & $627.200,00$ & $201.376,22$ & $9.623 .306,62$ \\
\hline Maio & $1.989 .384,73$ & $1.292 .448,65$ & $901.743,24$ & $2.136 .007,43$ & $931.314,19$ & $13.379,62$ & $846.720,00$ & $290.876,76$ & $8.401 .874,62$ \\
\hline Junho & $2.233 .695,14$ & $1.938 .672,97$ & $624.283,78$ & $2.297 .215,54$ & $1.303 .839,86$ & $857.418,51$ & $846.720,00$ & $268.501,62$ & $10.370 .347,43$ \\
\hline Julho & $1.396 .059,46$ & $1.292 .448,65$ & $277.459,46$ & $2.498 .725,68$ & $670.546,22$ & $371.448,22$ & $376.320,00$ & $402.752,43$ & $7.285 .760,11$ \\
\hline Agosto & $698.029,73$ & $1.938 .672,97$ & $208.094,59$ & $1.370 .268,92$ & $447.030,81$ & $282.281,94$ & $282.240,00$ & $358.002,16$ & $5.584 .621,12$ \\
\hline Setembro & $1.047 .044,59$ & $1.292 .448,65$ & $312.141,89$ & $886.644,59$ & $745.051,35$ & $156.157,96$ & $313.600,00$ & $380.377,30$ & $5.133 .466,33$ \\
\hline Outubro & $1.256 .453,51$ & $1.938 .672,97$ & $312.141,89$ & $1.329 .966,89$ & $1.080 .324,46$ & $142.871,90$ & $470.400,00$ & $246.126,49$ & $6.776 .958,11$ \\
\hline Novembro & $1.047 .044,59$ & $1.292 .448,65$ & $208.094,59$ & $886.644,59$ & $856.809,05$ & $231.757,49$ & $407.680,00$ & $223.751,35$ & $5.154 .230,33$ \\
\hline Dezembro & $2.198 .793,65$ & 0,00 & $554.918,92$ & $1.894 .195,27$ & $1.117 .577,03$ & $764.696,80$ & $752.640,00$ & $402.752,43$ & $7.685 .574,10$ \\
\hline Janeiro & $139.605,95$ & 0,00 & $138.729,73$ & $161.208,11$ & $74.505,14$ & $106.007,77$ & $62.720,00$ & $44.750,27$ & $727.526,96$ \\
\hline TOTAL & $15.007 .639,19$ & $11.632 .037,84$ & $4.612 .763,51$ & $16.564 .133,11$ & $8.195 .564,86$ & $2.926 .020,21$ & $4.986 .240,00$ & $2.819 .267,03$ & $66.743 .665,75$ \\
\hline
\end{tabular}

\begin{tabular}{|c|c|c|c|c|c|c|c|c|c|}
\hline \multicolumn{10}{|c|}{ CUSTO ABSOLUTO (R\$) } \\
\hline Mês & Usina 1 & Usina 2 & Usina 3 & Usina 4 & Usina 5 & Usina 6 & Usina 7 & Usina 8 & TOTAL \\
\hline$\overline{\text { Abril }}$ & $2.742 .129,11$ & $590.377,78$ & $982.241,89$ & $2.835 .080,11$ & $884.863,78$ & 0,00 & $587.795,56$ & $183.973,00$ & $8.806 .461,22$ \\
\hline Maio & $1.817 .457,67$ & $1.180 .755,56$ & $823.815,78$ & $1.951 .418,78$ & $850.830,56$ & $12.223,35$ & $793.524,00$ & $265.738,78$ & $7.695 .764,47$ \\
\hline Junho & $2.040 .654,22$ & $1.771 .133,33$ & $570.334,00$ & $2.098 .695,67$ & $1.191 .162,78$ & $783.320,39$ & $793.524,00$ & $245.297,33$ & $9.494 .121,73$ \\
\hline Julho & $1.275 .408,89$ & $1.180 .755,56$ & $253.481,78$ & $2.282 .791,78$ & $612.598,00$ & $339.347,66$ & $352.677,33$ & $367.946,00$ & $6.665 .006,99$ \\
\hline Agosto & $637.704,44$ & $1.771 .133,33$ & $190.111,33$ & $1.251 .853,56$ & $408.398,67$ & $257.887,13$ & $264.508,00$ & $327.063,11$ & $5.108 .659,57$ \\
\hline Setembro & $956.556,67$ & $1.180 .755,56$ & $285.167,00$ & $810.022,89$ & $680.664,44$ & $142.662,78$ & $293.897,78$ & $347.504,56$ & $4.697 .231,67$ \\
\hline Outubro & $1.147 .868,00$ & $1.771 .133,33$ & $285.167,00$ & $1.215 .034,33$ & $986.963,44$ & $130.524,91$ & $440.846,67$ & $224.855,89$ & $6.202 .393,57$ \\
\hline Novembro & $956.556,67$ & $1.180 .755,56$ & $190.111,33$ & $810.022,89$ & $782.764,11$ & $211.729,01$ & $382.067,11$ & $204.414,44$ & $4.718 .421,12$ \\
\hline Dezembro & $2.008 .769,00$ & 0,00 & $506.963,56$ & $1.730 .503,44$ & $1.020 .996,67$ & $698.611,69$ & $705.354,67$ & $367.946,00$ & $7.039 .145,03$ \\
\hline Janeiro & $127.540,89$ & 0,00 & $126.740,89$ & $147.276,89$ & $68.066,44$ & $96.846,57$ & $58.779,56$ & $40.882,89$ & $666.134,13$ \\
\hline$\overline{\text { TOTAL }}$ & $3.710 .645,56$ & $10.626 .800,00$ & $214.134,56$ & $15.132 .700,33$ & $7.487 .308,89$ & $.673 .153,49$ & $4.672 .974,67$ & $2.575 .622,00$ & $61.093 .339,49$ \\
\hline
\end{tabular}




\section{RESUMO DOS CUSTOS ABSOLUTOS DE TRANSPORTE}

\begin{tabular}{|c|c|c|c|c|c|c|c|c|c|}
\hline \multicolumn{10}{|c|}{ CUSTO ABSOLUTO (R\$) } \\
\hline Mês & Usina 1 & Usina 2 & Usina 3 & Usina 4 & Usina 5 & Usina 6 & Usina 7 & Usina 8 & TOTAL \\
\hline Abril & $2.451 .000,00$ & $550.000,00$ & $914.500,00$ & $2.271 .500,00$ & $786.500,00$ & 0,00 & $550.000,00$ & $218.250,00$ & $7.741 .750,00$ \\
\hline Maio & $1.624 .500,00$ & $1.060 .000,00$ & $767.000,00$ & $1.510 .500,00$ & $756.250,00$ & $10.281,70$ & $742.500,00$ & $321.750,00$ & $6.792 .781,70$ \\
\hline Junho & $1.824 .000,00$ & $1.560 .000,00$ & $531.000,00$ & $1.738 .500,00$ & $1.058 .750,00$ & $658.891,60$ & $742.500,00$ & $313.500,00$ & $8.427 .141,60$ \\
\hline Julho & $1.180 .000,00$ & $1.100 .000,00$ & $240.000,00$ & $1.891 .000,00$ & $576.000,00$ & $293.383,00$ & $330.000,00$ & $486.000,00$ & $6.096 .383,00$ \\
\hline Agosto & $590.000,00$ & $1.650 .000,00$ & $180.000,00$ & $1.020 .000,00$ & $384.000,00$ & $225.369,90$ & $247.500,00$ & $432.000,00$ & $4.728 .869,90$ \\
\hline Setembro & $885.000,00$ & $1.140 .000,00$ & $270.000,00$ & $682.000,00$ & $640.000,00$ & $130.182,00$ & $275.000,00$ & $459.000,00$ & $4.481 .182,00$ \\
\hline Outubro & $1.062 .000,00$ & $1.710 .000,00$ & $270.000,00$ & $1.336 .500,00$ & $928.000,00$ & $120.174,90$ & $412.500,00$ & $288.750,00$ & $6.127 .924,90$ \\
\hline Novembro & $840.000,00$ & $1.060 .000,00$ & $171.000,00$ & $693.000,00$ & $701.500,00$ & $193.701,40$ & $338.000,00$ & $255.000,00$ & $4.252 .201,40$ \\
\hline Dezembro & $1.764 .000,00$ & 0,00 & $456.000,00$ & $1.386 .500,00$ & $915.000,00$ & $580.283,00$ & $624.000,00$ & $459.000,00$ & $6.184 .783,00$ \\
\hline Janeiro & $112.000,00$ & 0,00 & $114.000,00$ & $110.000,00$ & $61.000,00$ & $87.807,50$ & $52.000,00$ & $51.000,00$ & $587.807,50$ \\
\hline$\overline{\text { TOTAL }}$ & $12.332 .500,00$ & $9.830 .000,00$ & $3.913 .500,00$ & $12.639 .500,00$ & $6.807 .000,00$ & $2.300 .075,00$ & $4.314 .000,00$ & $3.284 .250,00$ & $55.420 .825,00$ \\
\hline
\end{tabular}




\section{RESUMO DOS CUSTOS ABSOLUTOS DE TRANSPORTE}

\begin{tabular}{|c|c|c|c|c|c|c|c|c|c|}
\hline \multicolumn{10}{|c|}{ CUSTO ABSOLUTO (R\$) } \\
\hline Mês & Usina 1 & Usina 2 & Usina 3 & Usina 4 & Usina 5 & Usina 6 & Usina 7 & Usina 8 & TOTAL \\
\hline Abril & $2.507 .419,01$ & $472.000,00$ & $1.198 .259,07$ & $3.470 .461,30$ & $1.106 .078,52$ & 0,00 & $439.803,70$ & $229.791,67$ & $9.423 .813,27$ \\
\hline Maio & $1.477 .295,08$ & $1.173 .720,74$ & $1.004 .991,48$ & $2.388 .759,07$ & $1.063 .537,04$ & $15.279,18$ & $593.735,00$ & $331.921,30$ & $8.049 .238,89$ \\
\hline Junho & $1.740 .800,99$ & $1.854 .557,78$ & $695.763,33$ & $2.569 .042,78$ & $1.488 .951,85$ & $979.149,64$ & $593.735,00$ & $306.388,89$ & $10.228 .390,26$ \\
\hline Julho & $911.644,44$ & $1.017 .092,96$ & $243.820,74$ & $2.794 .397,41$ & $765.746,67$ & $424.184,21$ & $263.882,22$ & $459.583,33$ & $6.880 .351,99$ \\
\hline Agosto & $455.822,22$ & $1.593 .521,92$ & $153.432,22$ & $1.532 .411,48$ & $327.737,78$ & $322.358,63$ & $217.941,33$ & $408.518,52$ & $5.011 .744,10$ \\
\hline Setembro & $683.733,33$ & $996.209,26$ & $230.148,33$ & $694.090,73$ & $759.449,63$ & $178.328,32$ & $219.901,85$ & $434.050,93$ & $4.195 .912,39$ \\
\hline Outubro & $820.480,00$ & $1.729 .255,56$ & $230.148,33$ & $1.189 .879,09$ & $1.233 .702,96$ & $163.155,99$ & $329.852,78$ & $280.856,48$ & $5.977 .331,20$ \\
\hline Novembro & $683.733,33$ & $1.027 .534,81$ & $153.432,22$ & $694.090,73$ & $841.385,60$ & $264.661,03$ & $285.872,41$ & $255.324,07$ & $4.206 .034,21$ \\
\hline Dezembro & $1.481 .784,37$ & 0,00 & $618.456,30$ & $1.820 .875,18$ & $1.276 .244,44$ & $873.263,86$ & $527.764,44$ & $459.583,33$ & $7.057 .971,93$ \\
\hline Janeiro & $91.164,44$ & 0,00 & $102.288,15$ & $120.790,37$ & $54.622,96$ & $85.263,71$ & $43.980,37$ & $69.984,07$ & $568.094,08$ \\
\hline TOTAL & $10.853 .877,22$ & $9.863 .893,03$ & $4.630 .740,19$ & $17.274 .798,14$ & $8.917 .457,45$ & $3.305 .644,56$ & $3.516 .469,11$ & $3.236 .002,59$ & $61.598 .882,30$ \\
\hline
\end{tabular}

\begin{tabular}{|c|c|c|c|c|c|c|c|c|c|}
\hline \multicolumn{10}{|c|}{ CUSTO ABSOLUTO (R\$) } \\
\hline Mês & Usina 1 & Usina 2 & Usina 3 & Usina 4 & Usina 5 & Usina 6 & Usina 7 & Usina 8 & TOTAL \\
\hline Abril & $2.386 .979,80$ & $465.740,00$ & $1.129 .578,00$ & $3.260 .334,00$ & $1.017 .592,33$ & 0,00 & $436.066,67$ & $211.569,00$ & $8.907 .859,80$ \\
\hline Maio & $1.434 .872,53$ & $1.165 .996,33$ & $947.388,00$ & $2.244 .126,00$ & $978.454,17$ & $14.056,85$ & $588.690,00$ & $305.599,67$ & $7.679 .183,55$ \\
\hline Junho & $1.676 .278,23$ & $1.844 .933,00$ & $655.884,00$ & $2.413 .494,00$ & $1.369 .835,83$ & $900.818,15$ & $588.690,00$ & $282.092,00$ & $9.732 .025,20$ \\
\hline Julho & $907.606,67$ & $1.006 .098,83$ & $235.578,17$ & $2.625 .204,00$ & $704.487,00$ & $390.249,68$ & $261.640,00$ & $423.138,00$ & $6.554 .002,34$ \\
\hline Agosto & $453.803,33$ & $1.578 .447,83$ & $151.517,00$ & $1.439 .628,00$ & $322.272,00$ & $296.570,09$ & $215.728,88$ & $376.122,67$ & $4.834 .089,80$ \\
\hline Setembro & $680.705,00$ & $984.779,17$ & $227.275,50$ & $676.618,12$ & $709.070,33$ & $164.062,14$ & $218.033,33$ & $399.630,33$ & $4.060 .173,93$ \\
\hline Outubro & $816.846,00$ & $1.717 .015,00$ & $227.275,50$ & $1.142 .387,13$ & $1.135 . \mathrm{C}$ & $150.103,59$ & $327.050,00$ & $258.584,33$ & $5.774 .268,39$ \\
\hline Novembro & $680.705,00$ & $1.016 .758,67$ & $151.517,00$ & $6.618,12$ & 789 & $243.488,27$ & $283.443,33$ & $235.076,67$ & $4.077 .246,62$ \\
\hline Dezembro & $1.469 .144,52$ & 0,00 & $583.008,00$ & $1.735 .177,80$ & 1.174. & $803.403,18$ & $523.280,00$ & $423.138,00$ & $6.711 .296,50$ \\
\hline Janeiro & $90.760,67$ & 0,00 & $101.011,33$ & $118.387,33$ & $53.712,00$ & $80.235,66$ & $43.606,67$ & $67.570,00$ & $555.283,66$ \\
\hline TOTAL & $10.597 .701,74$ & $\begin{array}{l}9.779 .768,83 \\
\end{array}$ & $4.410 .032,50$ & $16.331 .974,50$ & $8.254 .215,06$ & $3.042 .987,61$ & $3.486 .228,88$ & $2.982 .520,67$ & $58.885 .429,79$ \\
\hline
\end{tabular}




\section{RESUMO DOS CUSTOS ABSOLUTOS DE TRANSPORTE}

\begin{tabular}{|c|c|c|c|c|c|c|c|c|c|}
\hline \multicolumn{10}{|c|}{ CUSTO ABSOLUTO (R\$) } \\
\hline Mês & Usina 1 & Usina 2 & Usina 3 & Usina 4 & Usina 5 & Usina 6 & Usina 7 & Usina 8 & TOTAL \\
\hline Abril & $2.398 .651,48$ & $462.694,59$ & $1.075 .155,41$ & $3.103 .256,08$ & $968.566,76$ & 0,00 & $434.251,35$ & $201.376,22$ & $8.643 .951,88$ \\
\hline Maio & $1.437 .655,08$ & $1.127 .271,89$ & $901.743,24$ & $2.136 .007,43$ & $931.314,19$ & $13.379,62$ & $586.239,32$ & $290.876,76$ & $7.424 .487,54$ \\
\hline Junho & $1.681 .972,97$ & $1.773 .496,22$ & $624.283,78$ & $2.297 .215,54$ & $1.303 .839,86$ & $857.418,51$ & $586.239,32$ & $268.501,62$ & $9.392 .967,83$ \\
\hline Julho & $905.643,24$ & $989.624,59$ & $229.535,14$ & $2.498 .725,68$ & $670.546,22$ & $371.448,22$ & $260.550,81$ & $402.752,43$ & $6.328 .826,33$ \\
\hline Agosto & $452.821,62$ & $1.544 .093,23$ & $150.585,41$ & $1.370 .268,92$ & $319.611,89$ & $282.281,94$ & $214.652,67$ & $358.002,16$ & $4.692 .317,84$ \\
\hline Setembro & $679.232,43$ & $971.271,62$ & $225.878,11$ & $666.691,04$ & $681.341,89$ & $156.157,96$ & $217.125,68$ & $380.377,30$ & $3.978 .076,03$ \\
\hline Outubro & $815.078,92$ & $1.663 .378,38$ & $225.878,11$ & $1.110 .019,39$ & $1.080 .324,46$ & $142.871,90$ & $325.688,51$ & $246.126,49$ & $5.609 .366,15$ \\
\hline Novembro & $679.232,43$ & $998.801,08$ & $150.585,41$ & $666.691,04$ & $761.245,93$ & $231.757,49$ & $282.263,38$ & $223.751,35$ & $3.994 .328,11$ \\
\hline Dezembro & $1.462 .994,39$ & 0,00 & $554.918,92$ & $1.674 .250,08$ & $1.117 .577,03$ & $764.696,80$ & $521.101,62$ & $402.752,43$ & $6.498 .291,27$ \\
\hline Janeiro & $90.564,32$ & 0,00 & $100.390,27$ & $117.217,84$ & $53.268,65$ & $81.275,91$ & $43.425,14$ & $68.860,54$ & $555.002,66$ \\
\hline TOTAL & $10.603 .846,89$ & $9.530 .631,61$ & $4.238 .953,78$ & $15.640 .343,04$ & $7.887 .636,87$ & $2.901 .288,35$ & $3.471 .537,81$ & $2.843 .377,30$ & $57.117 .615,65$ \\
\hline
\end{tabular}

\begin{tabular}{|c|c|c|c|c|c|c|c|c|c|}
\hline \multicolumn{10}{|c|}{ CUSTO ABSOLUTO (R\$) } \\
\hline Mês & Usina 1 & Usina 2 & Usina 3 & Usina 4 & Usina 5 & Usina 6 & Usina 7 & Usina 8 & TOTAL \\
\hline$\overline{\text { Abril }}$ & $2.282 .936,47$ & $456.117,78$ & $982.241,89$ & $2.835 .080,11$ & $884.863,78$ & 0,00 & $430.326,67$ & $183.973,00$ & $8.055 .539,69$ \\
\hline Maio & $1.396 .693,97$ & $1.059 .921,56$ & $823.815,78$ & $1.951 .418,78$ & $850.830,56$ & $12.223,35$ & $580.941,00$ & $265.738,78$ & $6.941 .583,77$ \\
\hline Junho & $1.619 .896,23$ & $1.650 .299,33$ & $570.334,00$ & $2.098 .695,67$ & $1.191 .162,78$ & $783.320,39$ & $580.941,00$ & $245.297,33$ & $8.739 .946,73$ \\
\hline Julho & $901.404,44$ & $959.226,56$ & $218.867,89$ & $2.282 .791,78$ & $612.598,00$ & $339.347,66$ & $258.196,00$ & $367.946,00$ & $5.940 .378,33$ \\
\hline$\overline{\text { Agosto }}$ & $450.702,22$ & $1.482 .481,05$ & $148.574,67$ & $1.251 .853,56$ & $313.869,33$ & $257.887,13$ & $212.330,46$ & $327.063,11$ & $4.444 .761,53$ \\
\hline Setembro & $676.053,33$ & $945.800,56$ & $222.862,00$ & $647.105,70$ & $633.399,78$ & $142.662,78$ & $215.163,33$ & $347.504,56$ & $3.830 .552,04$ \\
\hline Outubro & $811.264,00$ & $1.569 .743,33$ & $222.862,00$ & $1.052 .121,63$ & $986.963,44$ & $130.524,91$ & $322.745,00$ & $224.855,89$ & $5.321 .080,20$ \\
\hline Novembro & $676.053,33$ & $965.939,56$ & $148.574,67$ & $647.105,70$ & $711.867,90$ & $211.729,01$ & $279.712,33$ & $204.414,44$ & $3.845 .396,94$ \\
\hline Dezembro & $1.449 .722,50$ & 0,00 & $506.963,56$ & $1.567 .592,45$ & $1.020 .996,67$ & $698.611,69$ & $516.392,00$ & $367.946,00$ & 6.128.224,87 \\
\hline Janeiro & $90.140,44$ & 0,00 & $99.049,78$ & $114.693,78$ & $52.311,56$ & $78.458,74$ & $43.032,67$ & $71.754,00$ & $549.440,96$ \\
\hline$\overline{\text { TOTAL }}$ & $10.354 .866,94$ & $9.089 .529,71$ & $3.944 .146,22$ & $14.448 .459,15$ & $7.258 .863,79$ & $2.654 .765,66$ & $3.439 .780,46$ & $2.606 .493,11$ & $53.796 .905,06$ \\
\hline
\end{tabular}




\section{RESUMO DOS CUSTOS ABSOLUTOS DE TRANSPORTE}

\begin{tabular}{|c|c|c|c|c|c|c|c|c|c|}
\hline Mês & Usina 1 & Usina 2 & Usina 3 & Usina 4 & Usina 5 & Usina 6 & Usina 7 & Usina 8 & TOTAL \\
\hline Abril & $2.222 .127,05$ & $482.200,00$ & $914.500,00$ & $2.271 .500,00$ & $786.500,00$ & 0,00 & $449.700,00$ & $218.250,00$ & $7.344 .777,05$ \\
\hline Maio & $1.407 .595,52$ & $1.016 .980,00$ & $767.000,00$ & $1.510 .500,00$ & $756.250,00$ & $10.281,70$ & $607.095,00$ & $321.750,00$ & $6.397 .452,22$ \\
\hline Junho & $1.607 .098,46$ & $1.525 .980,00$ & $531.000,00$ & $1.738 .500,00$ & $1.058 .750,00$ & $658.891,60$ & $607.095,00$ & $313.500,00$ & $8.040 .815,06$ \\
\hline Julho & $947.200,00$ & $988.130,00$ & $217.025,00$ & $1.891 .000,00$ & $576.000,00$ & $293.383,00$ & $269.820,00$ & $486.000,00$ & $5.668 .558,00$ \\
\hline Agosto & $473.600,00$ & $1.504 .233,39$ & $152.430,00$ & $1.020 .000,00$ & $306.060,00$ & $225.369,90$ & $221.578,08$ & $432.000,00$ & $4.335 .271,37$ \\
\hline Setembro & $710.400,00$ & $986.350,00$ & $228.645,00$ & $632.799,51$ & $601.030,00$ & $130.182,00$ & $224.850,00$ & $459.000,00$ & $3.973 .256,51$ \\
\hline Outubro & $852.480,00$ & $1.578 .300,00$ & $228.645,00$ & $1.076 .604,55$ & $928.000,00$ & $120.174,90$ & $337.275,00$ & $288.750,00$ & $5.410 .229,45$ \\
\hline Novembro & $710.400,00$ & $983.520,00$ & $152.430,00$ & $633.799,41$ & $656.545,50$ & $193.701,40$ & $292.305,00$ & $255.000,00$ & $3.877 .701,31$ \\
\hline Dezembro & $1.535 .577,81$ & 0,00 & $456.000,00$ & $1.346 .601,12$ & $915.000,00$ & $580.283,00$ & $539.640,00$ & $459.000,00$ & $5.832 .101,93$ \\
\hline Janeiro & $94.720,00$ & 0,00 & $101.620,00$ & $110.020,00$ & $51.010,00$ & $75.525,78$ & $44.970,00$ & $77.220,00$ & $555.085,78$ \\
\hline TOTAL & $10.561 .198,83$ & $9.065 .693,39$ & $3.749 .295,00$ & $12.231 .324,58$ & $6.635 .145,50$ & $2.287 .793,28$ & $3.594 .328,08$ & $3.310 .470,00$ & $51.435 .248,66$ \\
\hline
\end{tabular}




\section{RESUMO DOS CUSTOS ABSOLUTOS DE TRANSPORTE}

\begin{tabular}{|c|c|c|c|c|c|c|c|c|c|}
\hline \multicolumn{10}{|c|}{ CUSTO ABSOLUTO (R\$) } \\
\hline Mês & Usina 1 & Usina 2 & Usina 3 & Usina 4 & Usina 5 & Usina 6 & Usina 7 & Usina 8 & TOTAL \\
\hline Abril & $1.960 .035,56$ & $472.000,00$ & $792.733,15$ & $2.325 .214,63$ & $710.098,52$ & 0,00 & $439.803,70$ & $314.928,33$ & $7.014 .813,89$ \\
\hline Maio & $1.299 .093,33$ & $944.000,00$ & $664.872,96$ & $1.600 .472,41$ & $682.787,04$ & $10.761,44$ & $593.735,00$ & $454.896,48$ & $6.250 .618,66$ \\
\hline Junho & $1.458 .631,11$ & $1.416 .000,00$ & $460.296,67$ & $1.721 .262,78$ & $955.901,85$ & $689.635,12$ & $593.735,00$ & $442.644,44$ & $7.738 .106,97$ \\
\hline Julho & $911.644,44$ & $944.000,00$ & $204.576,30$ & $1.872 .250,74$ & $491.606,67$ & $298.761,61$ & $263.882,22$ & $629.856,67$ & $5.616 .578,65$ \\
\hline Agosto & $455.822,22$ & $1.416 .000,00$ & $153.432,22$ & $1.026 .718,15$ & $327.737,78$ & $227.043,78$ & $197.911,67$ & $559.872,59$ & $4.364 .538,41$ \\
\hline Setembro & $683.733,33$ & $944.000,00$ & $230.148,33$ & $664.347,04$ & $546.229,63$ & $125.600,29$ & $219.901,85$ & $594.864,63$ & $4.008 .825,10$ \\
\hline Outubro & $820.480,00$ & $1.416 .000,00$ & $230.148,33$ & $996.520,56$ & $792.032,96$ & $114.914,10$ & $329.852,78$ & $384.912,41$ & $5.084 .861,14$ \\
\hline Novembro & $683.733,33$ & $944.000,00$ & $153.432,22$ & $664.347,04$ & $628.164,07$ & $186.406,18$ & $285.872,41$ & $349.920,37$ & $3.895 .875,62$ \\
\hline Dezembro & $1.435 .840,00$ & 0,00 & $409.152,59$ & $1.419 .286,85$ & $819.344,44$ & $615.057,60$ & $527.764,44$ & $629.856,67$ & $5.856 .302,60$ \\
\hline Janeiro & $91.164,44$ & 0,00 & $102.288,15$ & $120.790,37$ & $54.622,96$ & $85.263,71$ & $43.980,37$ & $69.984,07$ & $568.094,08$ \\
\hline TOTAL & $9.800 .177,78$ & $8.496 .000,00$ & $3.401 .080,93$ & $12.411 .210,56$ & $6.008 .525,93$ & $2.353 .443,82$ & $3.496 .439,44$ & $4.431 .736,67$ & $50.398 .615,12$ \\
\hline
\end{tabular}

\begin{tabular}{|c|c|c|c|c|c|c|c|c|c|}
\hline \multicolumn{10}{|c|}{ CUSTO ABSOLUTO (R\$) } \\
\hline Mês & Usina 1 & Usina 2 & Usina 3 & Usina 4 & Usina 5 & Usina 6 & Usina 7 & Usina 8 & TOTAL \\
\hline Abril & $1.951 .354,33$ & $465.740,00$ & $782.837,83$ & $2.278 .956,17$ & $698.256,00$ & 0,00 & $436.066,67$ & $304.065,00$ & $6.917 .276,00$ \\
\hline Maio & $1.293 .339,50$ & $931.480,00$ & $656.573,67$ & $1.568 .632,17$ & $671.400,00$ & $10.422,84$ & $588.690,00$ & $439.205,00$ & $6.159 .743,17$ \\
\hline Junho & $1.452 .170,67$ & $1.397 .220,00$ & $454.551,00$ & $1.687 .019,50$ & $939.960,00$ & $667.936,47$ & $588.690,00$ & $405.420,00$ & $7.592 .967,63$ \\
\hline Julho & $907.606,67$ & $931.480,00$ & $202.022,67$ & $1.835 .003,67$ & $483.408,00$ & $289.361,39$ & $261.640,00$ & $608.130,00$ & $5.518 .652,39$ \\
\hline Agosto & $453.803,33$ & $1.397 .220,00$ & $151.517,00$ & $1.006 .292,33$ & $322.272,00$ & $219.900,08$ & $196.230,00$ & $540.560,00$ & $4.287 .794,75$ \\
\hline Setembro & $680.705,00$ & $931.480,00$ & $227.275,50$ & $651.130,33$ & $537.120,00$ & $121.648,40$ & $218.033,33$ & $574.345,00$ & $3.941 .737,57$ \\
\hline Outubro & $816.846,00$ & $1.397 .220,00$ & $227.275,50$ & $976.695,50$ & $778.824,00$ & $111.298,45$ & $327.050,00$ & $371.635,00$ & $5.006 .844,45$ \\
\hline Novembro & $680.705,00$ & $931.480,00$ & $151.517,00$ & $651.130,33$ & $617.688,00$ & $180.541,10$ & $283.443,33$ & $337.850,00$ & 3.834.354,77 \\
\hline Dezembro & $1.429 .480,50$ & 0,00 & $404.045,33$ & $1.391 .051,17$ & $805.680,00$ & $595.705,45$ & $523.280,00$ & $608.130,00$ & $5.757 .372,45$ \\
\hline Janeiro & $90.760,67$ & 0,00 & $101.011,33$ & $118.387,33$ & $53.712,00$ & $82.580,97$ & $43.606,67$ & $67.570,00$ & $557.628,97$ \\
\hline$\overline{\text { TOTAL }}$ & $9.756 .771,67$ & $8.383 .320,00$ & $.358 .626,83$ & $12.164 .298,50$ & $5.908 .320,00$ & $2.279 .395,15$ & $3.466 .730,00$ & $4.256 .910,00$ & $49.574 .372,15$ \\
\hline
\end{tabular}




\section{RESUMO DOS CUSTOS ABSOLUTOS DE TRANSPORTE}

\begin{tabular}{|c|c|c|c|c|c|c|c|c|c|}
\hline \multicolumn{10}{|c|}{ CUSTO ABSOLUTO (R\$) } \\
\hline Mês & Usina 1 & Usina 2 & Usina 3 & Usina 4 & Usina 5 & Usina 6 & Usina 7 & Usina 8 & TOTAL \\
\hline Abril & $1.947 .132,97$ & $462.694,59$ & $778.024,59$ & $2.256 .443,38$ & $692.492,43$ & 0,00 & $434.251,35$ & $309.872,43$ & $6.880 .911,76$ \\
\hline Maio & $1.290 .541,62$ & $925.389,19$ & $652.536,76$ & $1.553 .136,35$ & $665.858,11$ & $10.258,12$ & $586.239,32$ & $447.593,51$ & $6.131 .552,99$ \\
\hline Junho & $1.449 .029,19$ & $1.388 .083,78$ & $451.756,22$ & $1.670 .354,19$ & $932.201,35$ & $657.380,78$ & $586.239,32$ & $413.163,24$ & $7.548 .208,08$ \\
\hline Julho & $905.643,24$ & $925.389,19$ & $200.780,54$ & $1.816 .876,49$ & $479.417,84$ & $284.788,49$ & $260.550,81$ & $619.744,86$ & $5.493 .191,46$ \\
\hline Agosto & $452.821,62$ & $1.388 .083,78$ & $150.585,41$ & $996.351,62$ & $319.611,89$ & $216.424,90$ & $195.413,11$ & $550.884,32$ & $4.270 .176,66$ \\
\hline Setembro & $679.232,43$ & $925.389,19$ & $225.878,11$ & $644.698,11$ & $532.686,49$ & $119.725,94$ & $217.125,68$ & $585.314,59$ & $3.930 .050,54$ \\
\hline Outubro & $815.078,92$ & $1.388 .083,78$ & $225.878,11$ & $967.047,16$ & $772.395,41$ & $109.539,55$ & $325.688,51$ & $378.732,97$ & $4.982 .444,42$ \\
\hline Novembro & $679.232,43$ & $925.389,19$ & $150.585,41$ & $644.698,11$ & $612.589,46$ & $177.687,93$ & $282.263,38$ & $344.302,70$ & $3.816 .748,61$ \\
\hline Dezembro & $1.426 .388,11$ & 0,00 & $401.561,08$ & $1.377 .309,59$ & $799.029,73$ & $586.291,26$ & $521.101,62$ & $619.744,86$ & $5.731 .426,26$ \\
\hline Janeiro & $90.564,32$ & 0,00 & $100.390,27$ & $117.217,84$ & $53.268,65$ & $81.275,91$ & $43.425,14$ & $68.860,54$ & $555.002,66$ \\
\hline TOTAL & $9.735 .664,86$ & $8.328 .502,70$ & $3.337 .976,49$ & $12.044 .132,84$ & $5.859 .551,35$ & $2.243 .372,88$ & $3.452 .298,24$ & $4.338 .214,05$ & $49.339 .713,42$ \\
\hline
\end{tabular}

\begin{tabular}{|c|c|c|c|c|c|c|c|c|c|}
\hline \multicolumn{10}{|c|}{ CUSTO ABSOLUTO (R\$) } \\
\hline Mês & Usina 1 & Usina 2 & Usina 3 & Usina 4 & Usina 5 & Usina 6 & Usina 7 & Usina 8 & TOTAL \\
\hline$\overline{\text { Abril }}$ & $1.938 .019,56$ & $456.117,78$ & $767.635,78$ & $2.207 .855,22$ & $680.050,22$ & 0,00 & $430.326,67$ & $322.893,00$ & $6.802 .898,22$ \\
\hline Maio & $1.284 .501,33$ & $912.235,56$ & $643.823,56$ & $1.519 .692,56$ & $653.894,44$ & $9.902,56$ & $580.941,00$ & $466.401,00$ & $6.071 .392,00$ \\
\hline Junho & $1.442 .247,11$ & $1.368 .353,33$ & $445.724,00$ & $1.634 .386,33$ & $915.452,22$ & $634.594,78$ & $580.941,00$ & $430.524,00$ & $7.452 .222,78$ \\
\hline Julho & $901.404,44$ & $912.235,56$ & $198.099,56$ & $1.777 .753,56$ & $470.804,00$ & $274.917,21$ & $258.196,00$ & $645.786,00$ & $5.439 .196,32$ \\
\hline$\overline{\text { Agosto }}$ & $450.702,22$ & $1.368 .353,33$ & $148.574,67$ & $974.897,11$ & $313.869,33$ & $208.923,23$ & $193.647,00$ & $574.032,00$ & $4.232 .998,89$ \\
\hline Setembro & $676.053,33$ & $912.235,56$ & $222.862,00$ & $630.815,78$ & $523.115,56$ & $115.576,02$ & $215.163,33$ & $609.909,00$ & $3.905 .730,58$ \\
\hline Outubro & $811.264,00$ & $1.368 .353,33$ & $222.862,00$ & $946.223,67$ & $758.517,56$ & $105.742,71$ & $322.745,00$ & $394.647,00$ & $4.930 .355,27$ \\
\hline Novembro & $676.053,33$ & $912.235,56$ & $148.574,67$ & $630.815,78$ & $601.582,89$ & $166.401,56$ & $279.712,33$ & $358.770,00$ & $3.774 .146,11$ \\
\hline Dezembro & $1.419 .712,00$ & 0,00 & $396.199,11$ & $1.347 .651,89$ & $784.673,33$ & $565.969,35$ & $516.392,00$ & $645.786,00$ & $5.676 .383,69$ \\
\hline Janeiro & $90.140,44$ & 0,00 & $99.049,78$ & $114.693,78$ & $52.311,56$ & $78.458,74$ & $43.032,67$ & $71.754,00$ & $549.440,96$ \\
\hline$\overline{\text { TOTAL }}$ & $9.690 .097,78$ & $8.210 .120,00$ & $3.293 .405,11$ & $11.784 .785,67$ & $5.754 .271,11$ & $2.160 .486,16$ & $3.421 .097,00$ & $4.520 .502,00$ & $48.834 .764,83$ \\
\hline
\end{tabular}




\section{RESUMO DOS CUSTOS ABSOLUTOS DE TRANSPORTE}

\begin{tabular}{|c|c|c|c|c|c|c|c|c|c|}
\hline Mês & Usina 1 & Usina 2 & Usina 3 & Usina 4 & Usina 5 & Usina 6 & Usina 7 & Usina 8 & TOTAL \\
\hline Abril & $2.036 .480,00$ & $482.200,00$ & $787.555,00$ & $2.197 .580,00$ & $663.130,00$ & 0,00 & $449.700,00$ & $347.490,00$ & $6.964 .135,00$ \\
\hline Maio & $1.349 .760,00$ & $964.400,00$ & $660.530,00$ & $1.512 .620,00$ & $637.625,00$ & $9.828,39$ & $77.625,00$ & $501.930,00$ & $5.714 .318,39$ \\
\hline Junho & $1.515 .520,00$ & $1.446 .600,00$ & $457.290,00$ & $1.626 .780,00$ & $892.675,00$ & $629.841,72$ & $607.095,00$ & $463.320,00$ & $7.639 .121,72$ \\
\hline Julho & $947.200,00$ & $964.400,00$ & $203.240,00$ & $1.769 .480,00$ & $459.090,00$ & $272.858,10$ & $269.820,00$ & $694.980,00$ & $5.581 .068,10$ \\
\hline Agosto & $473.600,00$ & $1.446 .600,00$ & $152.430,00$ & $970.360,00$ & $306.060,00$ & $207.358,41$ & $202.365,00$ & $617.760,00$ & $4.376 .533,41$ \\
\hline Setembro & $710.400,00$ & $964.400,00$ & $228.645,00$ & $627.880,00$ & $510.100,00$ & $114.710,37$ & $224.850,00$ & $656.370,00$ & $4.037 .355,37$ \\
\hline Outubro & $852.480,00$ & $1.446 .600,00$ & $228.645,00$ & $941.820,00$ & $739.645,00$ & $104.950,71$ & $337.275,00$ & $424.710,00$ & $5.076 .125,71$ \\
\hline Novembro & $710.400,00$ & $964.400,00$ & $152.430,00$ & $627.880,00$ & $586.615,00$ & $170.244,21$ & $292.305,00$ & $386.100,00$ & $3.890 .374,21$ \\
\hline Dezembro & $1.491 .840,00$ & 0,00 & $406.480,00$ & $1.341 .380,00$ & $765.150,00$ & $561.730,29$ & $539.640,00$ & $694.980,00$ & $5.801 .200,29$ \\
\hline Janeiro & $94.720,00$ & 0,00 & $101.620,00$ & $114.160,00$ & $51.010,00$ & $77.871,09$ & $44.970,00$ & $77.220,00$ & $561.571,09$ \\
\hline TOTAL & $10.182 .400,00$ & $8.679 .600,00$ & $3.378 .865,00$ & $11.729 .940,00$ & $5.611 .100,00$ & $2.149 .393,29$ & $3.045 .645,00$ & $4.864 .860,00$ & $49.641 .803,29$ \\
\hline
\end{tabular}

